IGOR DE LUNA VIEIRA

Avaliação na linhagem endotelial tEnd dos efeitos diretos da transferência gênica de IFN $\beta$ e p19arf e efeitos parácrinos mediados pela linhagem B16 transduzida pelos mesmos vetores adenovirais

Dissertação apresentada à Faculdade de Medicina da Universidade de São Paulo para obtenção do título de Mestre em Ciências.

Programa de: Oncologia

Orientador: Dr. Bryan Eric Strauss

São Paulo 



\section{IGOR DE LUNA VIEIRA}

Avaliação na linhagem endotelial tEnd dos efeitos diretos da transferência gênica de IFN $\beta$ e p19arf e efeitos parácrinos mediados pela linhagem B16 transduzida pelos mesmos vetores adenovirais

Dissertação apresentada à Faculdade de Medicina da Universidade de São Paulo para obtenção do título de Mestre em Ciências.

Programa de: Oncologia

Orientador: Dr. Bryan Eric Strauss 


\section{Dados Internacionais de Catalogação na Publicação (CIP)}

Preparada pela Biblioteca da

Faculdade de Medicina da Universidade de São Paulo

Creprodução autorizada pelo autor

Vieira, Igor de Luna

Avaliação na linhagem endotelial tEnd dos efeitos diretos da transferência gênica de IFN $\beta$ e p19arf e efeitos parácrinos mediados pela linhagem B16 transduzida pelos mesmos vetores adenovirais / Igor de Luna Vieira. -- São Paulo, 2016.

Dissertação(mestrado)--Faculdade de Medicina da Universidade de São Paulo.

Programa de Oncologia.

Orientador: Bryan Eric Strauss.

Descritores: 1.Interferon beta 2.Melanoma 3.Moduladores da angiogênese 4.Proteína supressora de tumor p53 5.Morte celular 6.Peptídeos e proteínas de sinalização intercelular

USP/FM/DBD-049/16 


\section{DEDICATÓRIA}

Este trabalho é dedicado a minha mãe, meu pai e minha irmã, pelo incentivo, apoio e investimento. Sem a ajuda da minha família eu não conseguiria ter avançado na minha carreira. 


\section{AGRADECIMENTOS}

Agradeço primeiramente ao meu orientador prof. Dr. Bryan Eric Strauss pela oportunidade, por acreditar no meu trabalho e principalmente pela paciência para comigo. Agradeço em especial ao Dr. Rodrigo Tamura por estar sempre ao meu lado no cotidiano do laboratório, compartilhando suas experiências cientificas e de bancada que foram fundamentais para a minha evolução como cientista, o seu incentivo foi primordial para o avanço do meu projeto e da minha carreira.

Aos integrantes do Laboratório de Vetores Virais, sou grato pelo apoio e coleguismo. Agradeço a Daniela Zanatta, Aline Hunger, Ruan Medrano, João Catani, Marlous Lana, Paulo Del Valle, Ruana Calado, Samir Andrade. Também agradeço aos colegas pesquisadores do Centro de pesquisa translacional em oncologia - CTO e aos colegas do décimo andar do INCOR onde eu iniciei a minha pesquisa.

Agradeço a pesquisadora Dra. Cristina M. Fernandes por fornecer a linhagem endotelial tEnd, foi a principal linhagem do meu projeto.

Agradeço a minha família por me apoiar, incentivar e financiar meus estudos, minha mãe Célia Cordeiro de Luna Vieira, meu pai Oripe Malaquias Vieira, minha irmã Isabela de Luna Vieira e todos outros parentes que são tantos e tão importantes para $\operatorname{mim}$.

Por fim agradeço a agencias de fomento a pesquisa, CAPES por financiar minha bolsa e a FAPESP. 


\section{RESUMO}

A vascularização tem um papel central na progressão tumoral e representa um alvo terapêutico de grande interesse. A inibição da angiogênese tem potencial de retardar a progressão tumoral e inibir metástase. Em decorrência disto, terapias anti-angiogênicas têm demonstrado ser promissora no controle do crescimento tumoral. Segundo a literatura, interferon- $\beta$ (IFN $\beta$, ativador do sistema imune inato e adaptativo) e p19Arf (supressor de tumor e parceiro funcional de p53), quando estudados individualmente, alteram a vasculatura tumoral. Nosso grupo construiu e utilizou vetores adenovirais recombinantes portadores dos cDNAs de INF $\beta$ e p19Arf e observou que a transferência desta combinação de genes induziu morte celular e diminuiu progressão tumoral, resultados foram observados em modelos murinos de melanoma B16 de terapia genica in situ, vacina profilática e vacina terapêutica. Neste trabalho, exploramos a ideia que a combinação dos vetores adenovirais portadores de INF $\beta$ e p19Arf proporcionam efeitos anti-angiogênicos através de seu impacto em células endoteliais. Para averiguarmos essa hipótese, células endoteliais murinas (tEnd) foram transduzidas com os vetores adenovirais, revelando que o vetor Ad-p19 confere inibição da proliferação, formação de tubos, migração e induz aumento na expressão de genes relacionados a via de p53 e morte celular. O vetor AdIFN $\beta$ sozinho ou adicionado em combinação com Ad-p19, não teve impacto significante nestes ensaios. Alternativamente, a influencia indireta, ou parácrina, nas células tEnd cultivadas juntamente com as células B16 transduzidas com os vetores adenovirais também foi investigada. Quando as células B16 foram transduzidas com Ad-IFN $\beta$ ou a co-transdução AdIFN $\beta+$ Ad-p19 em co-cultura com a linhagem tEnd, houve inibição da proliferação. Não observamos efeito inibitório na tEnd da co-cultura quando as células da B16 foram transduzidas somente com Ad-p19. Seguindo o ensaio de co-cultura, produzimos meio condicionado da B16 transduzida com os vetores e aplicamos esses meios nas células tEnd. Observamos que Ad-IFN, sozinho ou em combinação com Ad-19, diminuiu a viabilidade, proliferação e levou a morte das células tEnd. Neste trabalho, constamos que inibição de células endoteliais pode ser realizada por transdução direta com Ad-19 ou quando estas células são expostas ao ambiente modulado por células tumorais transduzidas com o vetor Ad-IFN $\beta$. Mesmo que a transferência gênica de ambos IFN $\beta$ e p19Arf não demonstrou ser uma abordagem superior à aplicação dos genes isolados, observamos que nossa abordagem pode ter um impacto importante na inibição da angiogênese pelas células endoteliais.

Descritores: interferon beta; melanoma; moduladores da angiogênese; proteína supressora de tumor p53; morte celular; peptídeos e proteínas de sinalização intercelular. 


\section{ABSTRACT}

The vasculature plays a central role in tumor progression and represents a therapeutic target of great interest. Inhibition of angiogenesis has the potential to slow down tumor progression and inhibit metastasis. As a result, anti-angiogenic therapies have been shown to be promising for the control of tumor growth. According to the literature, interferon $\beta$ (IFN $\beta$, activator of the innate and adaptive immune systems) and p19Arf (tumor suppressor and functional partner of p53) when studied individually alter tumor vasculature. Our group has constructed and used recombinant adenovirus vectors carrying the cDNAs of INF $\beta$ and p19Arf and noted that the transfer of this combination of genes induced cell death and decreased tumor progression, as observed in the B16 murine model of in situ melanoma gene therapy as well as prophylactic and therapeutic vaccine approaches. In this study, we explore the idea that the combination of adenoviral vectors bearing INF $\beta$ and p19Arf produce anti-angiogenic effects due to their impact on endothelial cells. To test this hypothesis, murine endothelial cells (tEnd) were transduced with adenoviral vectors, revealing that Ad-p19 vector confers inhibition of proliferation, tube formation, migration and induces increased expression of genes related to the p53 cell death pathway. The Ad-IFN $\beta$ vector alone had no significant impact on these tests. Alternatively, influences on paracrine effects are evaluated on endothelial cells co-cultured with B16 cells that were previously transduced with adenoviral vectors. When the B16 cells were transduced with Ad-IFN $\beta$ or co-transduced with Ad-IFN $\beta+$ Ad-p19, co-culture resulted in the inhibition of proliferation of the endothelial cells. When B16 cells were transduced with Ad-p19 only, coculture did alter endothelial cell behavior. Following the co-culture assay, we produce conditioned medium from B16 cells that were transduced with the vectors and applied the media on tEnd cells. We noted that conditioned medium derived from B16 transduced with AdIFN alone or in combination with Ad-19 decreased the viability and proliferation and induced cell death of tEnd. In this work, we show that inhibition of endothelial cells can be performed directly by transduction with Ad-19 or when such cells are exposed to the environment modulated by tumor cells transduced with Ad-IFN $\beta$. Even though the gene transfer of both IFN $\beta$ and $\mathrm{p} 19$ was not found to be superior to the application of single genes, we observed that our approach may have an important impact on the inhibition of angiogenesis through endothelial cells.

Descriptors: interferon-beta; melanoma; angiogenesis modulating agents; tumor suppressor protein $\mathrm{p} 53$; cell death; intercellular signaling peptides and proteins. 


\section{SUMÁRIO}

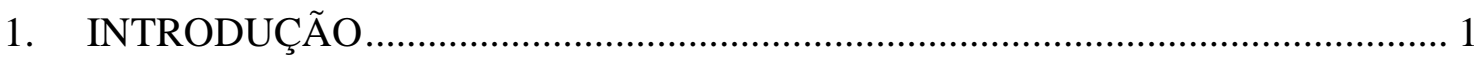

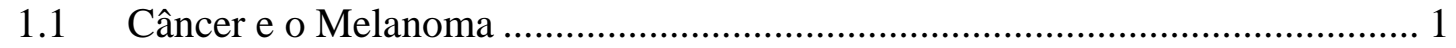

1.2 Carcinogênese e o Microambiente Tumoral .................................................... 1

1.3 Angiogênese Tumoral ................................................................................ 4

1.4 Estrutura dos vasos tumorais e células endoteliais ............................................. 6

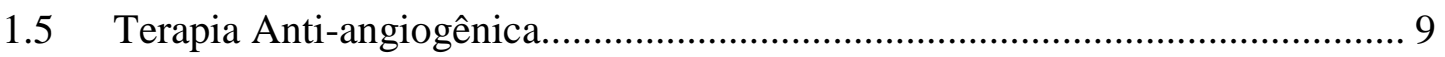

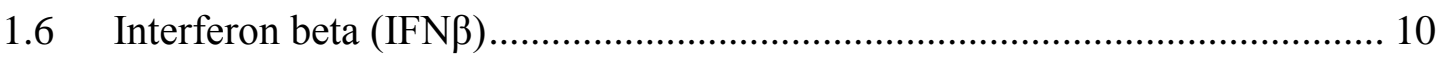

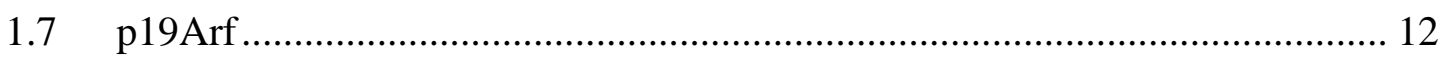

1.8 Interações entre as vias de IFN $\beta$ e p53/p19Arf.............................................. 14

1.9. Linha de pesquisa do Laboratório de Vetores Virais....................................... 15

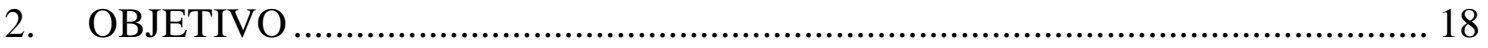

3. MATERIAL E MÉTODOS .......................................................................... 19

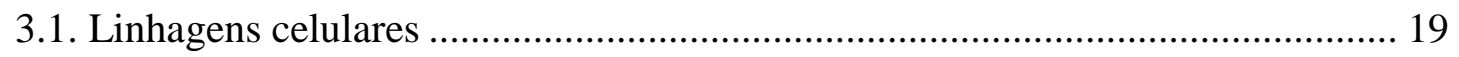

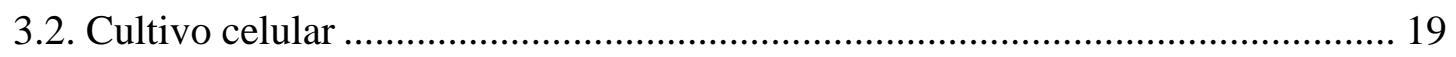

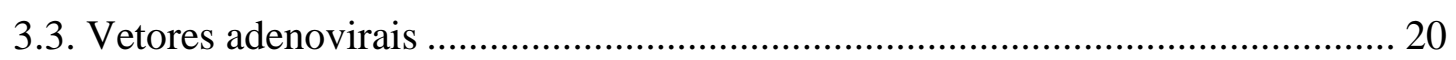

3.4. Produção e titulação dos vetores adenovirais .................................................... 21

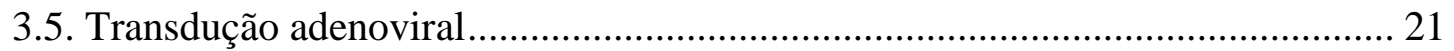

3.6. Eficiência de transdução pelo vetor Ad-GFP ................................................... 21

3.7. Ensaio de ELISA (Enzyme Linked Immunosorbent Assay) para a detecção da

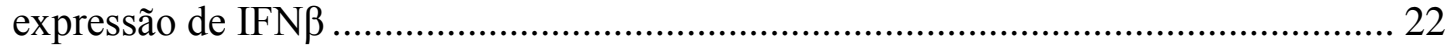

3.8. Imunofluorescência para detecção da expressão de p19Arf................................ 22

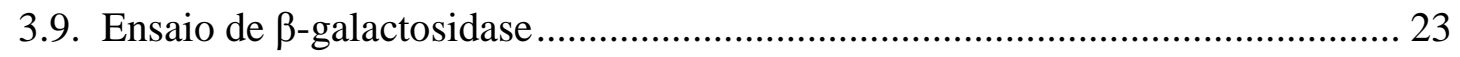

3.9. Estabelecimento de linhagem tEndTO pelo vetor lentiviral Lego-iT2.............. 23

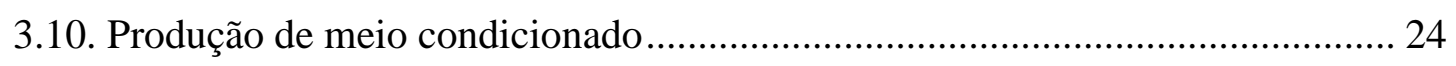

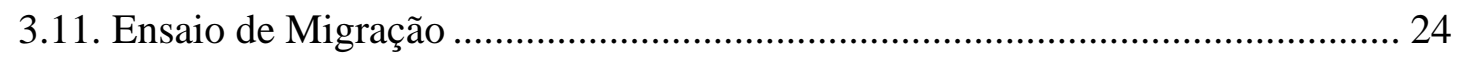

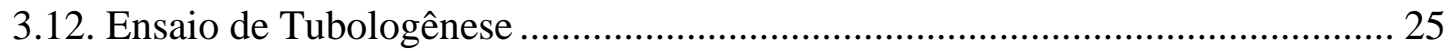

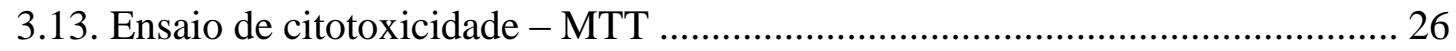

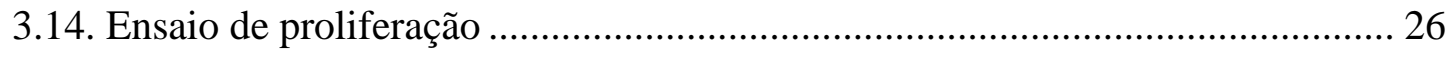

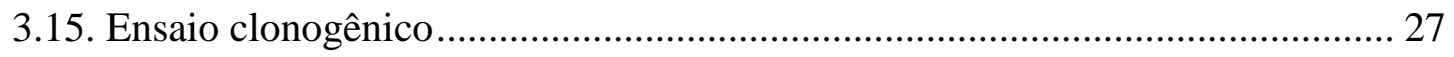




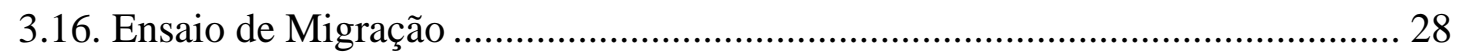

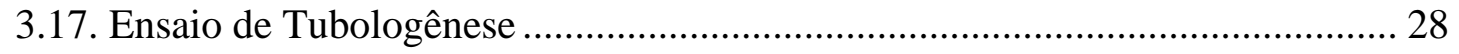

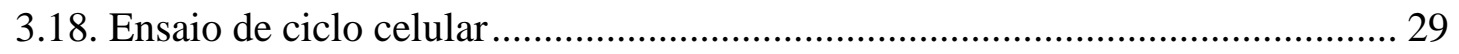

3.19. Ensaio de marcação de células apoptóticas por Anexina-V .............................. 29

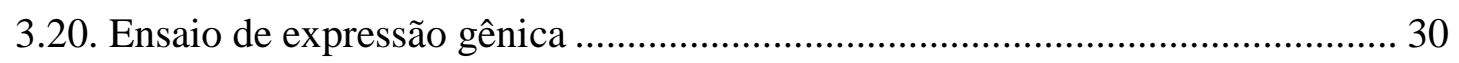

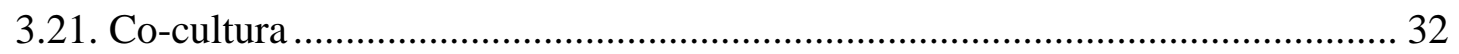

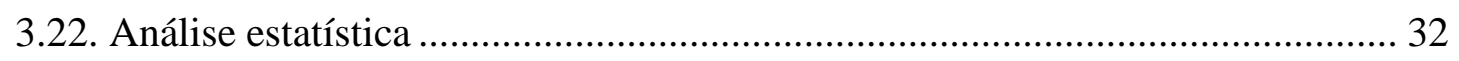

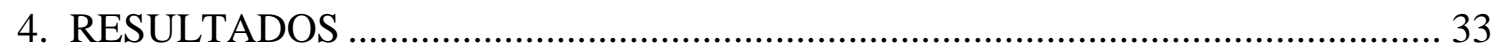

4.1. PRODUÇÃO E TITULAÇÃO DOS VETORES ADENOVIRAIS ................... 33

4.2. CARACTERIZAÇÃO DOS VETORES PELA EXPRESSÃO DO

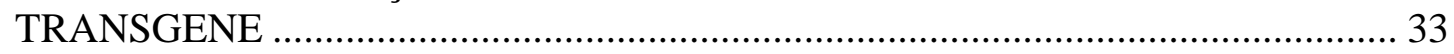

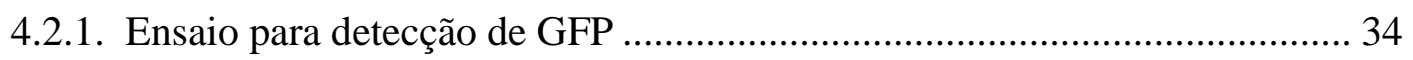

4.2.2. Ensaio para detecção da proteína Interferon-beta...................................... 35

4.2.3. Imunofluorescência para a proteína p19Arf .............................................. 36

4.2.4. Ensaio para detecção da $\beta$-galactosidase .................................................. 38

4.2.5. Ensaio quantitativo da expressão dos transgenes IFN $\beta$ e p19Arf .............. 39

4.3. ENSAIO DE EFICIÊNCIA DE TRANSDUÇÃO E ENSAIOS FUNCIONAIS DO TRATAMENTO COM VETORES ADENOVIRAIS DIRETAMENTE NA

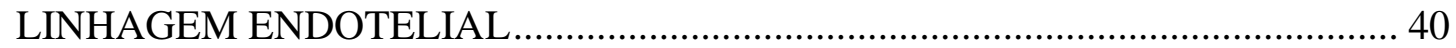

4.3.1. Curva de eficiência de transdução ................................................................ 40

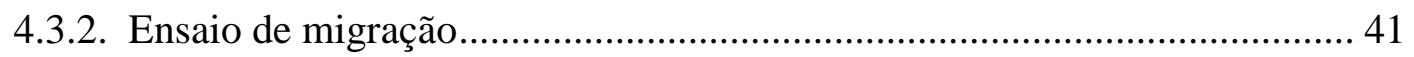

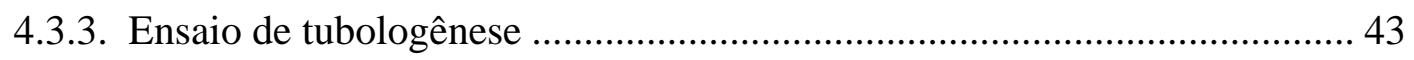

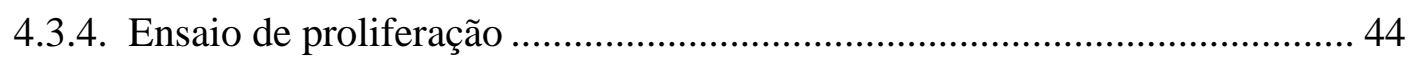

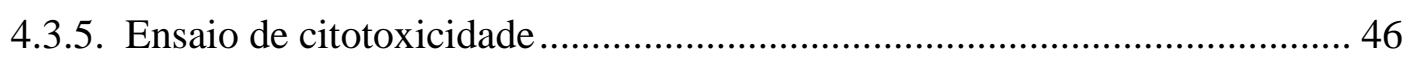

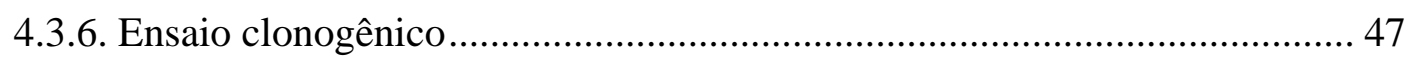

4.3.7. Ensaio de ciclo celular da linhagem tEnd .................................................... 49

4.3.8. Ensaio de marcação das células por Anexina-V .......................................... 51

4.4. EXPRESSÃO GÊNICA DAS CÉLULAS tEnd TRANSDUZIDAS PELOS

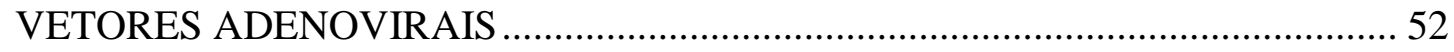

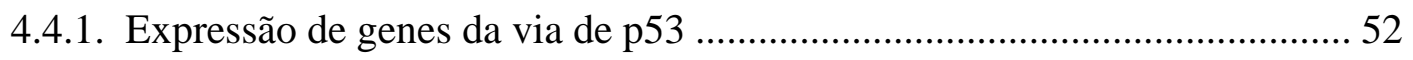

4.4.2. Expressão de fatores pró-angiogênicos ...................................................... 54

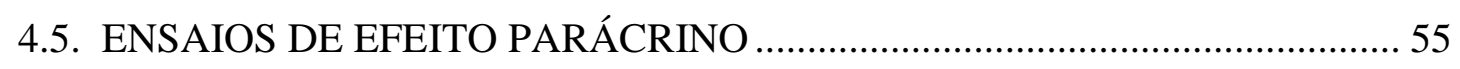

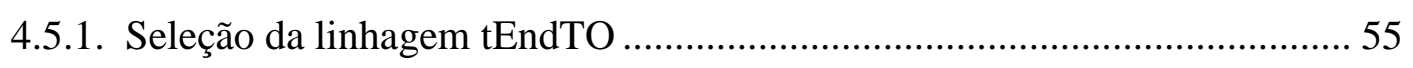

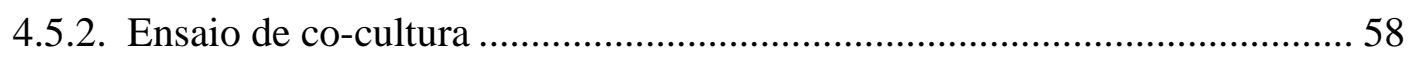

4.5.5. Ensaio de ciclo celular da linhagem tEnd tratada com meio condicionado. 65 4.5.6. Ensaio de morte celular revelada por anexina e P.I. da linhagem tEnd tratada

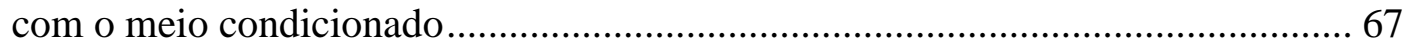

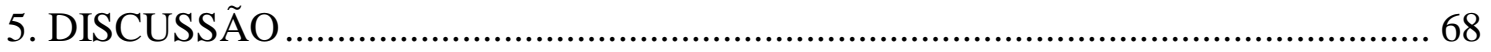




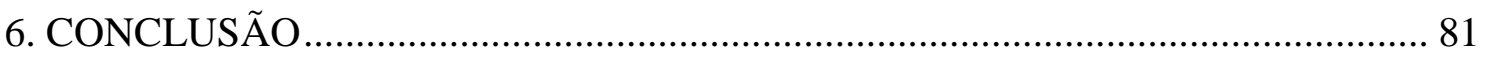

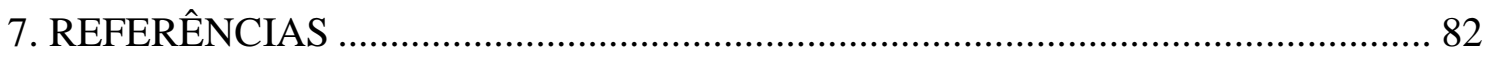

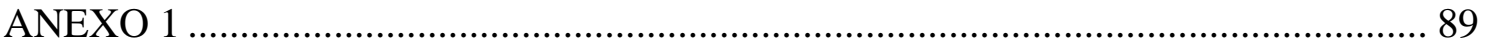

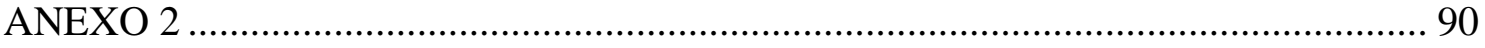

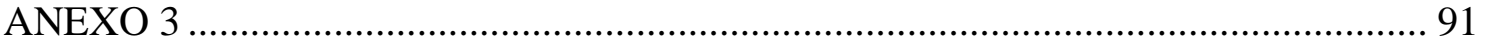

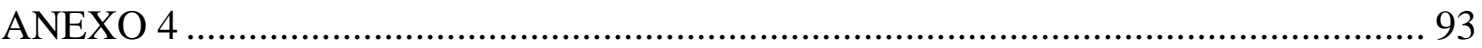

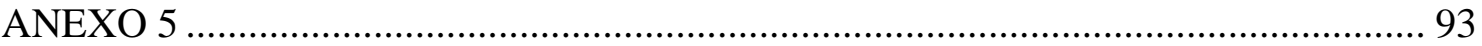




\section{LISTA DE FIGURAS}

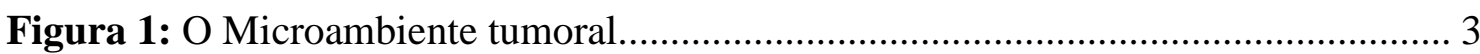

Figura 2: Balanço entre os fatores ativadores e inibidores da angiogênese.................... 4

Figura 3: Evolução tumoral e os vasos sanguíneos.................................................... 5

Figura 4: Brotamento de um novo vaso em direção ao tumor...................................... 7

Figura 5: Estrutura dos vasos tumorais comparada com vasos normais........................ 8

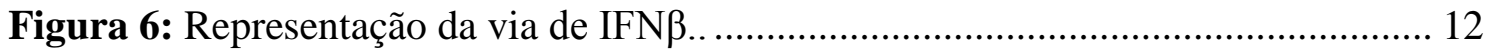

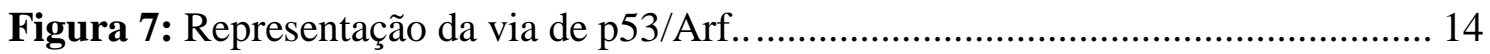

Figura 8: Representação da localização dos quatro campos onde foram tiradas as fotos

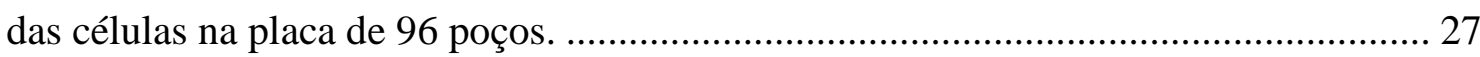

Figura 9: Ensaio de identificação de células tEnd GFP positivas no microscópio EVOS após transdução da linhagem tEnd com o vetor adenoviral Ad-GFP............................ 34

Figura 10: Citometria de fluxo para detecção de células GFP positivas....................... 35

Figura 11: Ensaio de ELISA para INF $\beta$ da linhagem B16 e tEnd transduzidas com os vetores adenovirais.

Figura 12: Ensaio de imunofluorescência para detecção da proteína p19Arf das linhagens B16 e tEnd transduzidas com os vetores adenovirais. ................................. 37

Figura 13: Ensaio para detecção de $\beta$-galactosidase.................................................. 38

Figura 14: Expressão gênica relativa de IFN $\beta$ e p19Arf da linhagem tEnd transduzida

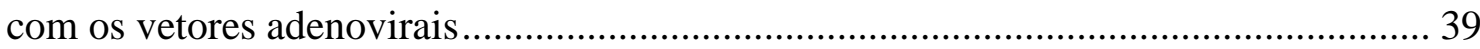

Figura 15: Eficiência de transdução nas linhagens B16, TM1 e tEnd.. ......................... 40

Figura 16: Ensaio de migração da linhagem tEnd transduzida pelos vetores adenovirais.

Figura 17: Ensaio de tubologênese no matrigel da linhagem endotelial tEnd transduzida pelos vetores adevirais 44

Figura 18: Ensaio de proliferação para a linhagem tEnd transduzida com os vetores adenovirais. 45

Figura 19: Ensaio de viabilidade por MTT da linhagem tEnd transduzida pelos vetores adenovirais. 46

Figura 20: Ensaio clonogênico da linhagem tEnd transduzida com os vetores adenovirais. 
Figura 21: Ensaio de ciclo celular por citometria para a linhagem tEnd tratada com os vetores adenovirais. 50

Figura 22: Citometria de fluxo para detecção de células apoptóticas da linhagem tEnd transduzidas pelos vetores adenovirais e marcadas com AnexinaV e P.I.

Figura 23: Expressão gênica dos genes da via de p53 na linhagem tEnd transduzida com os vetores adenovirais

Figura 24: Expressão gênica de genes pró-angiogênicos na linhagem tEnd transduzida com os vetores adenovirais 55

Figura 25: Linhagem tEndTO selecionada marcada com a proteína tomato................ 56

Figura 26: Linhagem tEndTO, 100\% das células marcadas com a proteína tomato. ... 57

Figura 27: Ensaio prévio da co-cultura entre as linhagens B16 transduzida com AdGFP e tEndTO.

Figura 28: Ensaio de co-cultura entre a linhagem B16 previamente transduzida pelos vetores adenovirais e a linhagem tEndTO. 60

Figura 29: Contagem das células da linhagem B16 e tEndTO do ensaio de co-cultura.

Figura 30: Ensaio de MTT para a linhagem tEnd tratada com o meio condicionado da linhagem B16 transduzida com os vetores adenovirais

Figura 31: Ensaio clonogênico da linhagem tEnd tratada com o meio condicionado proveniente da linhagem B16 transduzida com os vetores adenovirais. 64

Figura 32: Ensaio de ciclo celular por citometria para a linhagem tEnd tratada com os meios condicionados da linhagem B16 transduzida com os vetores adenovirais. 66

Figura 33: Porcentagem de células marcadas para AnexinaV e P.I da linhagem tEnd tratada com os meios condicionados da linhagem B16 transduzida com os vetores adenovirais 


\section{LISTA DE TABELAS}

Tabela 1: Tabela com as sequências de bases dos oligonucleotídeos 31

Tabela 2: Resultado da titulação biológica dos vetores virais. 33 


\section{INTRODUÇÃO}

\subsection{Câncer e o Melanoma}

O câncer é a segunda maior causa de morte por doenças da população brasileira, superado apenas por cardiopatias. Indicadores do Instituto Nacional do Câncer (INCA) apresentam estimativas de mais de 576 mil novos casos de câncer para o ano de 2015 (INCA, 2014).

O nome melanoma tem origem grega (melas "negro" e oma "tumor") e teve sua primeira descrição em relatos de Hipócrates a mais de 2500 anos atrás (Rebecca et al., 2012). Dentre os cânceres, o melanoma tem ocorrência relacionada à exposição à luz ultravioleta, histórico familiar da doença e ainda a presença de manchas na pele. Este câncer, presente em grande maioria na população caucasiana (Cho and Chiang, 2010), origina-se a partir de melanócitos que, após transformação, são capazes de se adaptar em diversos microambientes e possuem caráter altamente invasivo, o que contribui para seu alto potencial metastático, causando uma alta mortalidade associada ao melanoma maligno (Satyamoorthy and Herlyn, 2002).

\subsection{Carcinogênese e o Microambiente Tumoral}

A carcinogênese é um processo que engloba os eventos necessários para formar o câncer. Dentre estes eventos, há a perda de equilíbrio na proliferação celular onde as células se multiplicam de forma anômala, sendo capazes de se dividir na ausência de sinais mitogênicos e escapar dos mecanismos que devem limitar sua longevidade. $\mathrm{O}$ grau de proliferação tem uma correlação direta com o aumento da malignidade do tumor 
e com a sua agressividade biológica, capacidade de recidivar e está inversamente correlacionado com a sobrevida pós-operatória (Fischer et al., 2005). Com o acúmulo de células, existe a necessidade de nutri-las. Células tumorais emitem sinais que favorecem a neovascularização e angiogênese, um ponto que será discutido com mais detalhes adiante. Assim, o processo de carcinogênese altera o microambiente tumoral com a formação de novo de vasos sanguíneos. Além disso, algumas células tumorais perdem a dependência de proteínas de adesão, aumentam a produção de enzimas proteolíticas, invadem tecidos adjacentes e ganham entrada na vasculatura. As células que ainda sobrevivem à viagem pela circulação, poderão se instalar em tecidos distantes do tumor primário onde formam os focos metastáticos (Ferreira C and J, 2004).

O parênquima do tumor é constituído por células transformadas e por células estromais não tumorais (células endoteliais - CE, miofibroblastos, fibroblastos, adipócitos, células imunes e inflamatórias) como mostrando na imagem abaixo, figura 01. 


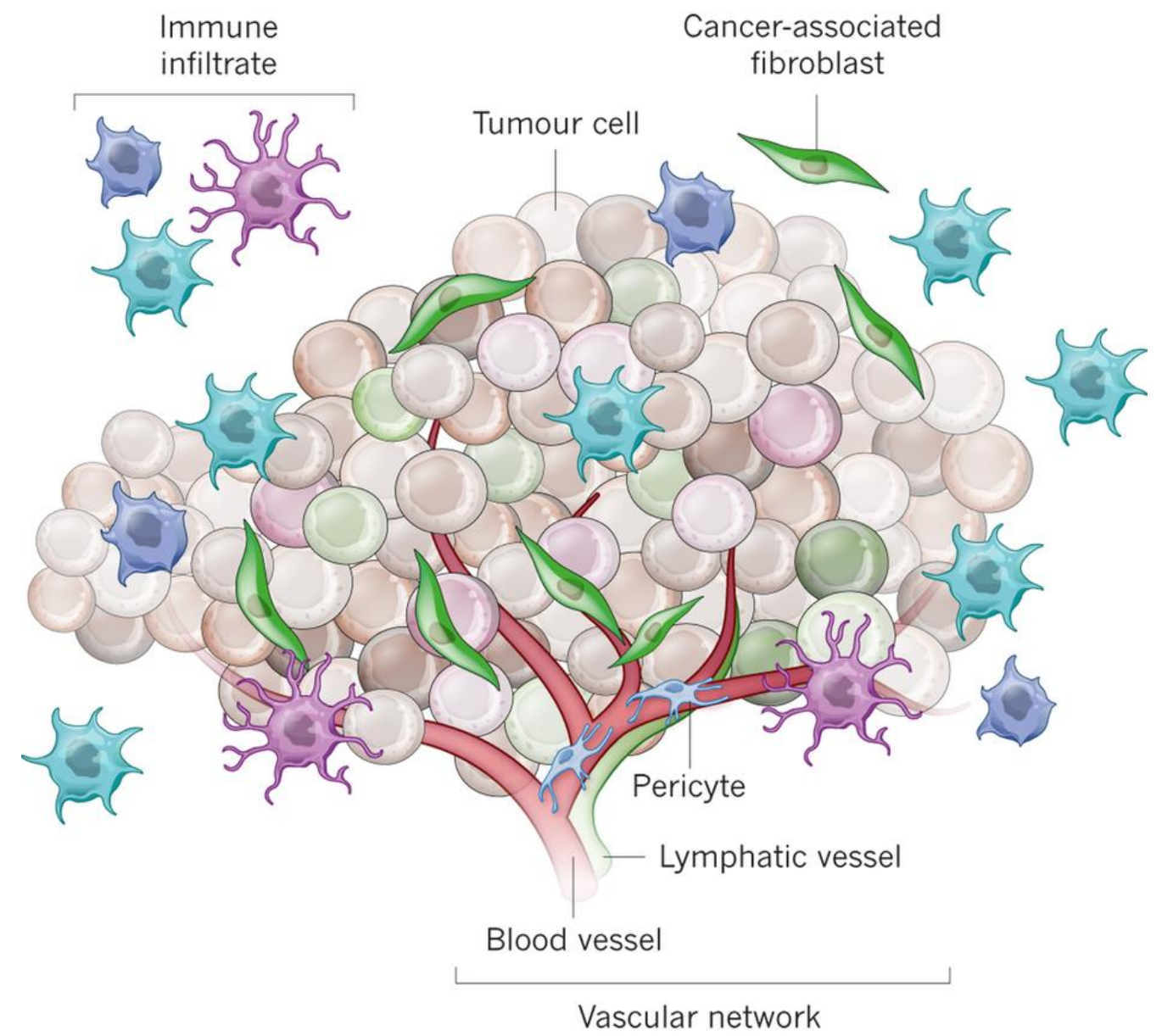

Figura 1: O Microambiente tumoral. O microambiente é composto por células tumorais e não tumorais que dão suporte as células tumorais como as células do sistema imune, células associadas ao tumor como os fibroblastos e as células dos vasos sanguíneos e linfáticos. Fonte: (Junttila and de Sauvage, 2013).

Esse conjunto de células não tumorais interage entre si e com as células tumorais, influenciam o comportamento biológico do tumor e, portanto o conjunto de células estromais representa um elemento importante na progressão tumoral (Hanahan and Weinberg, 2000). Juntas, as células do estroma contribuem para o remodelamento do microambiente tumoral, auxiliando o transporte de nutrientes e metabólitos e também a invasão e metástase do tumor (Stockmann et al., 2008).

Um ponto central nesse assunto é o papel da vasculatura tumoral, que apresenta grande importância na nutrição tumoral e serve como corredor para mobilização de células tumorais para metástase. A vasculatura tumoral também é importante para a 
infusão de agentes terapêuticos administrados sistemicamente. Por estes motivos, estudar a vasculatura tumoral é um ponto crítico não só para a compreensão da progressão tumoral, mas também para seu tratamento.

\subsection{Angiogênese Tumoral}

A indução do fenômeno de brotamentos de novos vasos no tumor se da pelo switch angiogênico, onde ocorre desbalanço dentre os fatores pró e anti-angiogênicos, com maior produção de fatores ativadores da desse fenômeno (Bergers and Benjamin, 2003), figura 2.

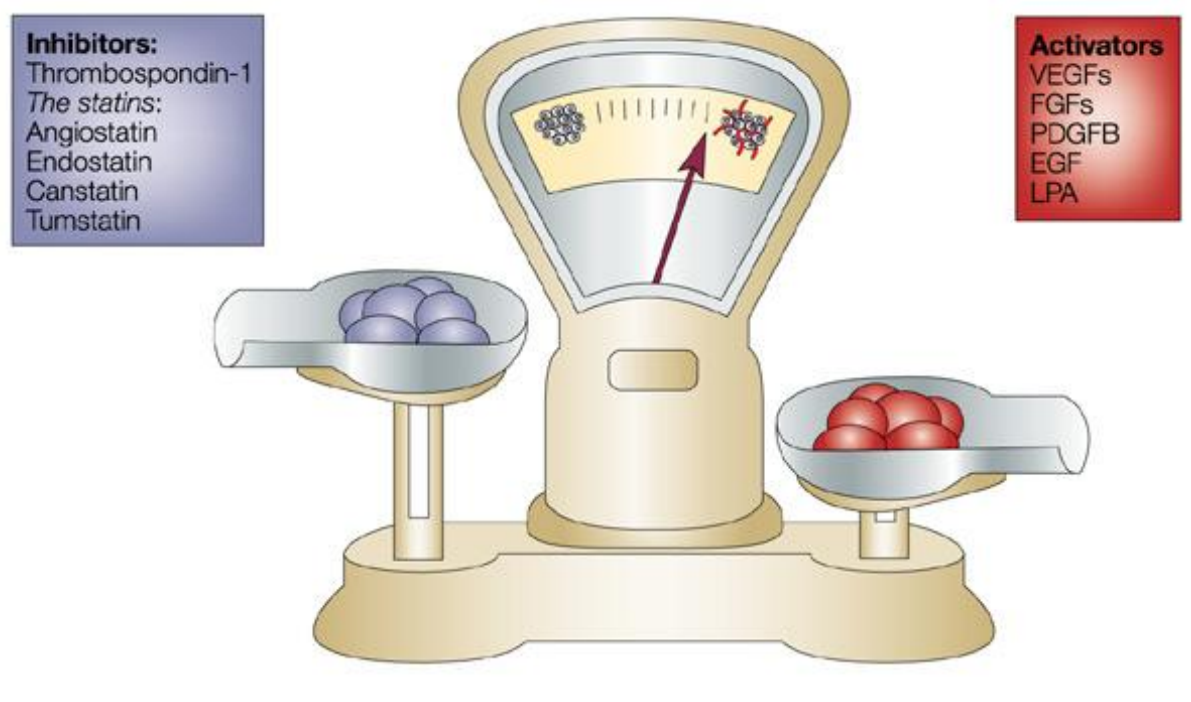

Nature Reviews | Cancer

Figura 2: Balanço entre os fatores ativadores e inibidores da angiogênese. A angiogênese tumoral pode ser ativada ou inibida dependendo da quantidade e dos tipos de fatores liberados no microambiente tumoral. Fonte: (Bergers and Benjamin, 2003). 
A neovascularização no tumor é induzida por 3 componentes principais na formação de novos vasos, as células tumorais, as células do estroma e as células do sistema imunológico. Essas células estimulam a formação da nova vasculatura devido a interações heterotípicas, onde as células de um grupo estimulam outros grupos ou a sí mesmas. A formação da nova vasculatura é dividida entre angiogênese (brotamento de novos vasos a partir da proliferação de células endoteliais de vasos próximos), vasculogênese (formação de vasos a partir de células provenientes da medula óssea) e arteriogênse (maturação dos vasos neoformados pela migração de células murais)(Carmeliet, 2005; Folkman, 2007).

A formação de novos vasos no tumor ocorre por diferentes mecanismos, incluindo brotamento e divisão dos tubos vasculares. Estes vasos evoluem juntamente com o crescimento tumoral de modo a suportar esse crescimento (Fagiani and Christofori, 2013), como visto na figura 3. O brotamento de novos vasos é coordenado pelas células endoteliais quando recebem e promovem estímulos angiogênicos (Saharinen et al., 2011). Conforme mencionado acima, o controle da angiogênese depende do balanço entre vários fatores ativadores (pró-angiogênicos) e inibidores (antiangiogênicos), secretados pelas células tumorais e pelos tecidos adjacentes (Eichhorn et al., 2007).
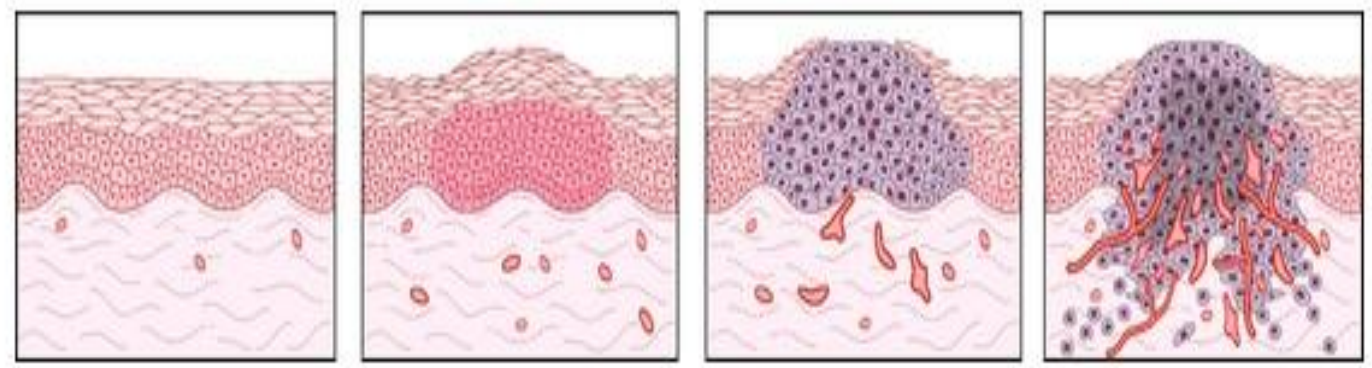

Figura 3: Evolução tumoral e os vasos sanguíneos. O crescimento tumoral é dependente do aumento na quantidade de vasos sanguíneos próximos a massa tumoral. Fonte: (Li et al., 2012b). 
Em termos simplificados, o acúmulo de células tumorais desenvolve necessidades nutricionais e de trocas gasosas. Na fase inicial da carcinogênese, este acúmulo de células cria um ambiente hipóxico e como consequência, ocorre ativação de HIF-1 $\alpha$ (fator induzido por hipóxia-1 $\alpha$ ), um importante fator de transcrição que, por sua vez, induz a expressão de compostos angiogênicos e fatores de crescimento, tais como o VEGF (fator de crescimento de endotélio vascular), apresentador de sinal mitótico para as células, em particular as endoteliais, que vão formar o novo vaso (Hellwig-Bürgel et al., 2005). A matriz extracelular também é alterada durante este processo, liberando sinais para a formação dos vasos e contribuindo para o remodelamento do estroma tumoral. Não será detalhada aqui, mas a linfangiogênese também se desenvolve por processos parecidos como os da angiogênese e os macrófagos e fibroblastos também participam nesses processos. Dessa forma, a neovascularização tumoral promove o fornecimento de oxigênio e nutrientes às células tumorais através de uma complexa rede de microcapilares que irriga o tumor, drena os metabólitos e desempenha papel na disseminação das células tumorais metastáticas pela corrente sanguínea ou linfática para órgãos distantes (Boudreau and Myers, 2003; Carmeliet and Jain, 2011).

\subsection{Estrutura dos vasos tumorais e células endoteliais}

A monocamada de CEs compõe o sistema vascular e tem influencia direta na regulação da trombose, aderência plaquetária, modulação do tônus vascular e do fluído sanguíneo, regulação da inflamação e nas respostas imunes pela modulação da interação com leucócitos, monócitos e linfócitos com a parede vascular (Dudley, 2012). 


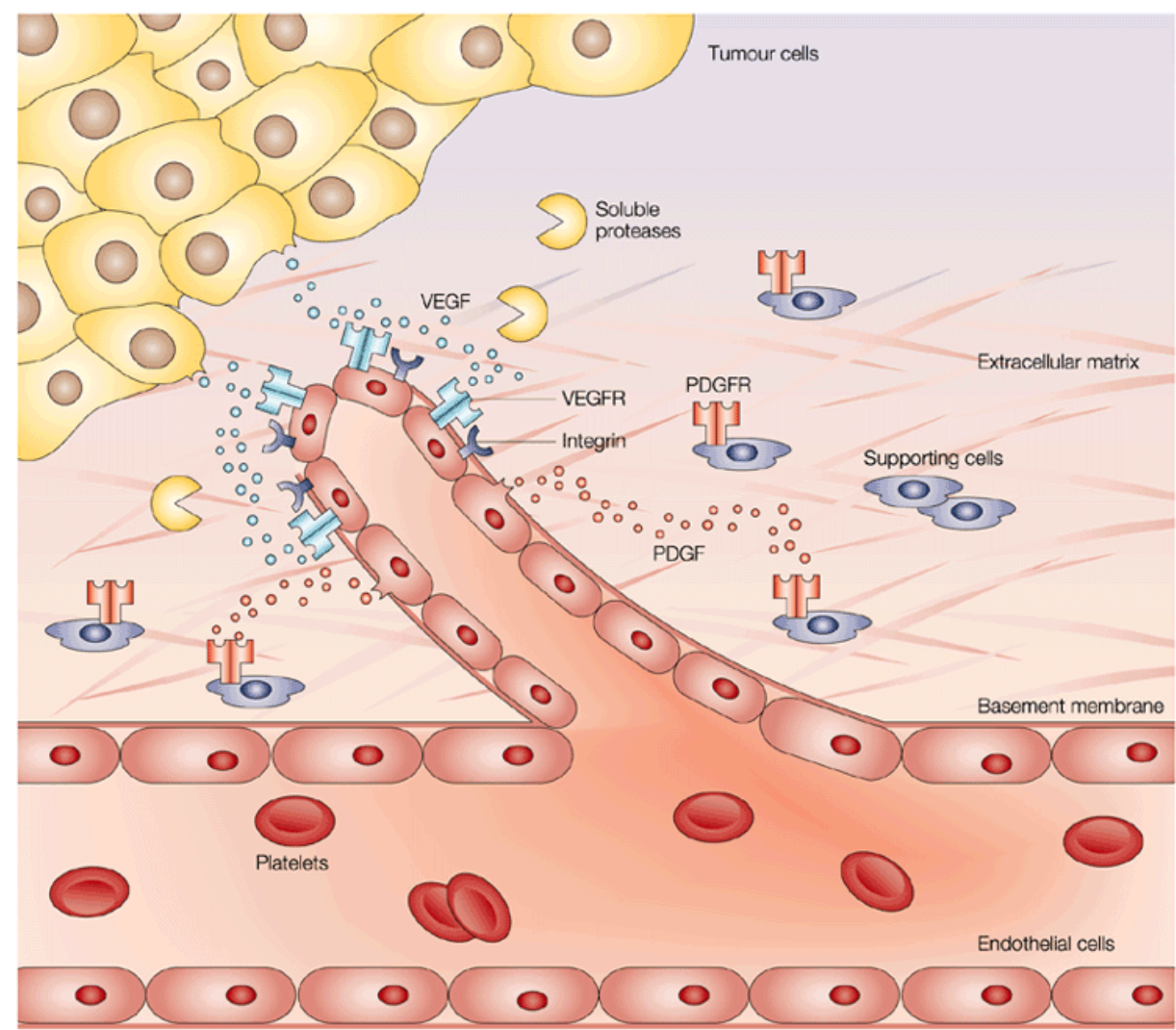

Nature Reviews | Drug Discovery

Figura 4: Brotamento de um novo vaso em direção ao tumor. As células tumorais liberam fatores próangiogênicos que induzem a formação de novos vasos sanguíneos pela ativação das células endoteliais que estão próximas. Essa interação das células tumorais com o microambiente induz secreção de proteases que liberam espaço para a invasão de novos vasos. As células endoteliais também liberam fatores como PDGF, importante estimulador de células suporte do microambiente. Fonte: (Cristofanilli et al., 2002).

Perturbações na estrutura endotelial podem resultar em algumas disfunções ou patologias como arterioesclerose, disfunções hemostáticas e alterações na inflamação de resposta imune e metástases (Sumpio et al., 2002). A neoformação de vasos é um processo importante no desenvolvimento do feto, ciclo reprodutivo feminino, no reparo tecidual e no brotamento de vasos para a evolução do tumor (Gupta and Zhang, 2005). A estrutura da vasculatura sanguínea é hierarquizada, em artérias, vasos e pequenos capilares formados por células endoteliais e células murais que são representadas por 
células musculares lisas e pericitos que promovem a estabilidade dos vasos ao abraçar as CEs (Hirschi and D'Amore, 1996). Esses vasos estão envoltos pela membrana basal, rica em colágeno, lamina e fibronectina que promovem suporte e estabilidade aos vasos além de promoverem interações com integrinas expressas na superfície das CEs (Hynes, 2009), figura 04.
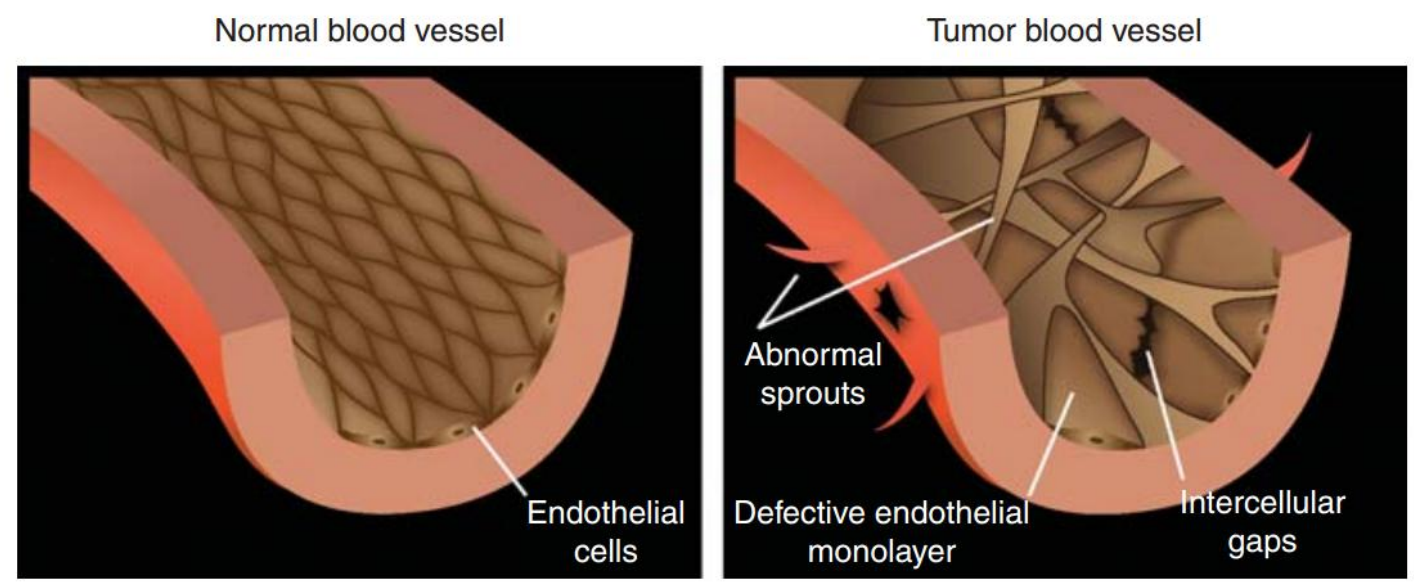

Figura 5: Estrutura dos vasos tumorais comparada com vasos normais. Comparação entre vasos normais encontrados em regiões não tumorais e um vaso pertencente ao tumor, onde o vaso tumoral possui monocamada de células endoteliais defectiva com buracos em sua formação e brotamentos de novos vasos anormais.Fonte: (Dudley, 2012).

As CEs de tecidos normais são diferentes das CEs do tumor, estudos demonstram que as CEs do tumor possuem diferenças morfológicas, citogenéticas e epigenéticas que distanciam estas células das normais. Essas células endoteliais tumorais podem mudar sua diversidade de fenótipo e assim dificultar a entrega de drogas no tumor ou apresentar resistência a drogas, que tem como alvo específico, a vasculatura do tumor (Dudley, 2012), figura 5. 


\subsection{Terapia Anti-angiogênica}

A abordagem anti-angiogênica tem como objetivo bloquear ou neutralizar o crescimento dos vasos na massa tumoral, inibindo a evolução do câncer. Um dos alvos mais utilizados é o fator de crescimento VEGF, o fator tem papel central na promoção da angiogênese. O anticorpo monoclonal anti-VEGF, Bevacizumab (ou Avastin), é utilizado clinicamente para o tratamento de vários tipos de câncer, incluindo glioblastoma recidivo, câncer colorretal e câncer de mama metastático. Em termos gerais, o tratamento com bevacizumab é administrado junto com a quimioterapia e oferece benefício. Porém, células tumorais frequentemente desenvolvem resistência à ação do anticorpo ou da droga ou de ambos, e o tumor volta a progredir. Alternativamente, a inibição dos receptores para VEGF, FGF, PDGF (e outros) pode limitar a angiogênese. Nestes casos, agentes farmacológicos, como Sunitinib ou Sorafenib, são utilizados para inibir a função de receptores e assim impedir a transdução de sinal do VEGF. Esse tratamento promove benefício clínico, mas em poucos casos e durante um curto período de tempo (Sennino et al., 2012).

Dados clínicos apresentam um paradoxo para o benefício das terapias antiangiogênicas. Mesmo que a terapia iniba a progressão tumoral, o número e densidade de

microvasos não necessariamente diminuem. Existem estudos que propõem que a inibição de VEGF resulte no bloqueio de novos vasos, mas não na destruição de vasos existentes. Assim, o crescimento tumoral é bloqueado pela inativação da angiogênese (Ellis and Hicklin, 2008).

As CEs em proliferação promovem a angiogênese e a via de VEGF, quando ativada, promove sobrevida para as CEs. A inibição de VEGF ou seu receptor deixa estas células mais vulneráveis. Este fenômeno cria uma oportunidade interessante para a utilização de quimioterápicos. Na ausência da sinalização do VEGF, o quimioterápico 
torna-se mais eficiente em matar as CEs, reforçando a abordagem anti-angiogênica (Browder et al., 2000).

Interferir na via de sinalização dos fatores pró-angiogênicos pode modificar a qualidade da vascularização tumoral. Neste caso, o tratamento anti-VEGF pode resultar na redução do diâmetro dos vasos e no extravasamento sanguíneo e influenciar no fluxo sanguíneo no tumor. O benefício deste remodelamento dos vasos para entrega de quimioterápicos e oxigenização é um assunto controverso, mas que merece mais estudos em relação a alguns fatores, como o tipo de tumor, a duração limitada da normalização e efeitos de vasoconstrição. Além disso, como mencionado acima, a combinação de terapia anti-VEGF com quimioterápicos poderia resultar na morte das CEs, resultando assim no aumento da permeabilidade dos vasos e perfusão da droga no tumor (Gimbrone et al., 1973; Sitohy et al., 2012).

Considerando os fatos descritos, a inibição da angiogenêse, sendo por inibição das vias de fatores de crescimento ou não, continua sendo um assunto de grande interesse para o sucesso do tratamento de câncer.

\subsection{Interferon beta (IFN $\beta$ )}

O IFN $\beta$ é uma citocina melhor conhecida por sua produção em resposta à infecção por vírus. No entanto, o IFN $\beta$ promove uma variedade de atividades, incluindo imunomodulação, inibição de angiogênese e indução de apoptose (Cao et al., 2001; Vered et al., 2006). Na fase precoce da infecção viral, o IRF-3 (interferon regulatory fator-3) é fosforilado e se torna ativo, induzindo a expressão de IFN $\beta$, que é secretado e interage na porção extracelular do seu receptor IFNAR (interferon $\alpha / \beta$ receptor), iniciando a transdução do sinal mediado pelo sistema JAK-STAT, ativando transcricionalmente os genes IFN $\alpha / \beta$, os quais se ligam juntos ao IFNAR promovendo 
um mecanismo de feedback positivo, figura 6. A ativação do sistema do interferon resulta na expressão de MHC de classe I, citocinas e fatores quimiotáticos, um conjunto de fatores que pode ativar o sistema imune, proporcionando maturação de células dendríticas, atração de macrófagos e ativação de células T-CD4 e T-CD8 (Sato et al., 2001). Na década de 80 , a proteína INF $\beta$ foi clinicamente usada no Japão como uma droga anti-câncer e mostrou efeito inibitório no crescimento de glioma e melanoma maligno. Desde então, proteínas recombinantes de IFN $\alpha / \beta$ continuam sendo utilizadas para a bioquimioterapia (Hamm et al., 2008; Yoshida et al., 2004). O IFN $\beta$ é usado na terapia coadjuvante do melanoma, porém essa terapia afeta outros tecidos além dos tumorais, levando à toxicidade tecidual se for administrada em altas doses (Kavanagh et al., 2005; Sabel and Sondak, 2003). Em contraste, a terapia gênica com IFN $\beta$ está ganhando espaço nos tratamentos atuais (Floros and Tarhini, 2015; Minn, 2015; Yoshida et al., 2004).

A atividade anti-angiogênica do IFN $\beta$ se dá por inibição da produção de fatores angiogênicos, como VEGF e b-FGF (Cao et al., 2001; Vered et al., 2006). O IFN $\beta$ aumenta a produção de IL-32, que retarda a produção do VEGF e consequentemente, cessa a formação de novos vasos (Meyer et al., 2012). No trabalho de (Lee et al., 2006), uma abordagem de terapia gênica com IFN $\beta$ foi realizada em um modelo de carcinoma de próstata, no qual foi observada a inibição da expressão de VEGF e consequente redução no número de vasos e inibição da progressão tumoral. Em outro exemplo, IFN $\beta$ recombinante foi capaz de inibir a expressão de VEGF em células primárias de endometriose humana. Outra atividade anti-angiogênica mediada por IFN $\beta$ envolve indução de morte das CEs (Izawa et al., 2002a). Outro estudo interessante, envolvendo IFN $\beta$, mostrou que a expressão de VEGF induz a degradação do receptor de IFN $\beta$ (IFNAR-1) em CEs (Zheng et al., 2011) e ainda dados da literatura indicam que IFN $\beta$ 
também inibe a expressão de VEGF-C e VEGFR3, que participam da linfangiogênese, in vitro, mas não reduz a densidade de vasos linfáticos in vivo (Roh et al., 2013).

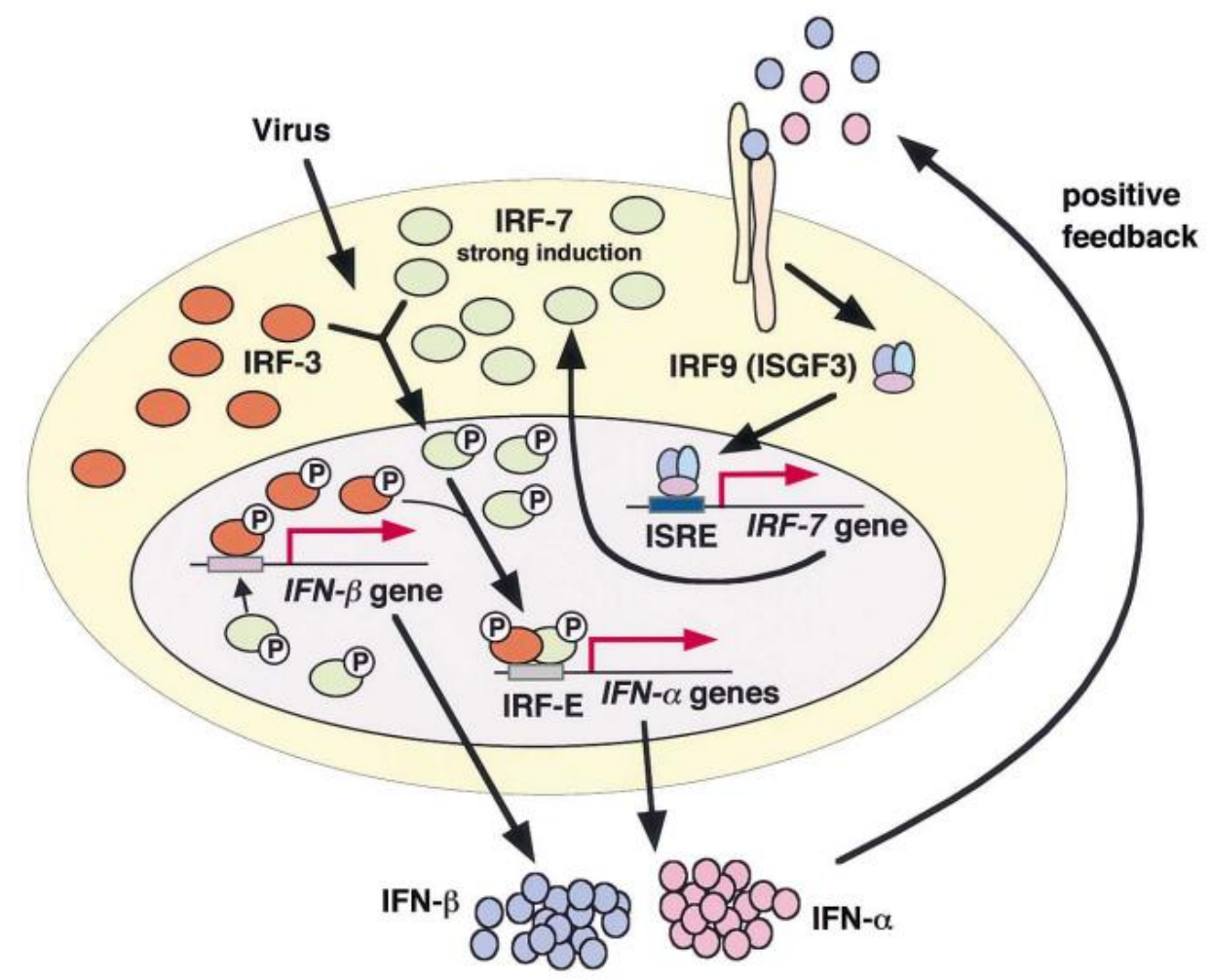

Figura 6: Representação da via de IFNß. A representação da via de interferon beta pela infecção por vírus na. Fonte: Sato 2001.

Outros estudos usando o interferon-beta mostraram eficiente inibição de progenitores endoteliais (Xiao et al., 2012), inibição do crescimento do tumor primário e de metástases por efeitos anti-angiogênicos incluindo indução de apoptose de células endoteliais (Izawa et al., 2002b). Frente aos dados mostrados em relação ao IFN $\beta$, fazse necessário aumentar a investigação sobre seus efeitos diretamente nas CEs do tumor.

\section{7 p19Arf}

Além do IFN $\beta$, nosso grupo estuda o p19Arf, conhecido como parceiro funcional de p53. Esta proteína é importante na proteção contra o melanoma e tem um 
grande impacto na inibição da angiogênese. O lócus CDKN2A codifica duas proteínas p16INK4A e p19Arf (p14Arf em humanos e p19Arf em camundongos) (Hussussian et al., 1994; Kamb et al., 1994; Soufir et al., 1998). A proteína p19Arf inibe MDM2, a qual induz ubiquitinação e posterior degradação de p53. Mutações no lócus CDKN2A de camundongos geram mutantes que facilmente adquirem linfomas, fibrossarcomas e muito frequentemente melanomas com pequena latência quando combinados com o gene mutado e ativado HRAS nos melanócitos (Yang et al., 2001). A via de p19Arf, figura 7, pode induzir a parada do ciclo celular e apoptose (Giglia-Mari and Sarasin, 2003) e, ainda, p19Arf pode levar a uma inibição do crescimento tumoral por via independente de p53. O trabalho de (Fatyol and Szalay, 2001), mostra que Arf regula a sinalização angiogênica por inibir a atividade do fator induzido por hipóxia (HIF-1 $\alpha$ ), conhecido como fator crítico na transcrição do VEGF e de outros fatores de crescimento e citocinas angiogênicas. Outros trabalhos mostram o p19Arf como supressor da angiogênese por controlar o mRNA do VEGF-A (Kawagishi et al., 2010), ou sua influencia no gatilho angiogênico de novos vasos no tumor via mecanismos dependentes ou independentes de p53(Ulanet and Hanahan, 2010). 


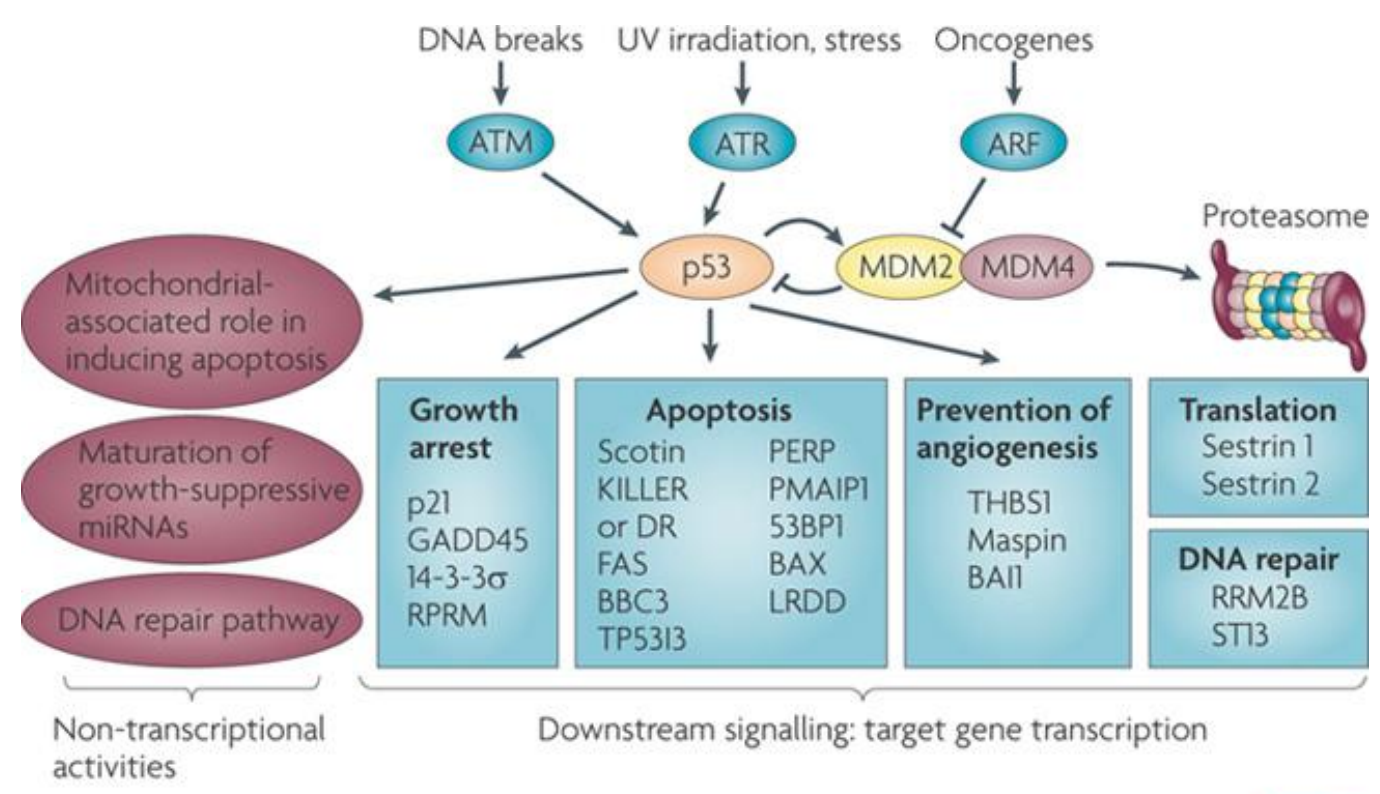

Nature Reviews | Cancer

Figura 7: Representação da via de p53/Arf. A ativação da vida de p53 por Arf pode levar a célula a alguns fenômenos como apoptose, arraste do ciclo celular e modulação da angiogênese pela transcrição de genes alvos e também indução de atividades não transcricionais. Fonte: (Brown et al., 2009).

\subsection{Interações entre as vias de IFN $\beta$ e p53/p19Arf}

A observação de que as vias de IFN $\beta$ e p53/p19Arf afetam a divisão celular fez com que alguns pesquisadores sugerissem um mecanismo de ação semelhante para os dois casos. No entanto, pouco se conhece a respeito destas interações eventuais. Em um exemplo, (Sandoval et al., 2004) descreve a participação de p14Arf na resposta à proteína recombinante IFN tipo I (IFN $\alpha / \beta)$. Neste trabalho, foi descrito que IFN $\beta$ inibe a proliferação de células deficientes em p14Arf, mas o IFN $\beta$ na presença de p14Arf induz apoptose mesmo na ausência de p53, enquanto que IFN $\beta$ ativa p53 somente na presença do Arf. Este conjunto de dados sugere que o papel de p53 pode ser menos importante do que o de p14Arf para a indução de apoptose em resposta a IFN tipo I.

Foi demonstrado que a proteína recombinante de IFN $\alpha / \beta$ estimula a transcrição de p53 resultando em um aumento na quantidade desta proteína (Takaoka et al., 2003). Neste estudo os autores identificaram no promotor do gene de p53 um elemento 
responsivo à cascata de sinalização dos IFNs tipo I. Embora os IFNs não sejam responsáveis pela ativação direta da proteína p53, que ocorre através de modificações pós-traducionais, os IFNs contribuem para aumentar a sensibilização de p53 frente a sinais de estresse celular. Os mesmos pesquisadores também demonstraram que na presença de p53 houve um aumento da ocorrência de células mortas após tratamento com as proteínas recombinantes IFN $\alpha$ e IFN $\beta$, indicando um efeito sinérgico próapoptótico com implicações terapêuticas importantes (Takaoka et al., 2003). Contudo, é possível que existam outras vias ainda não conhecidas que possam ligar os IFNs à apoptose sem participação de p53 (Clemens, 2003). A relação indireta entre IFN e p53 foi sugerida por Burch e colaboradores. IFN tipo I pode induzir expressão de membros da família DAPK e foi observado que DAPK3 (ZIP kinase) promove a fosforilação de MDM2 na posição S166 (Burch et al., 2004), porém o impacto deste evento sobre p53 ainda não foi explorado.

\subsection{Linha de pesquisa do Laboratório de Vetores Virais}

Nosso grupo, o Laboratório de Vetores Virais (LVV, situado no Instituto do Câncer do Estado de São Paulo, ICESP) trabalha com constante empenho no desenvolvimento de vetores virais usados como mecanismos de entrega de genes terapêuticos relevantes para o tratamento antitumoral. A estratégia fundamental que foi desenvolvida no LVV é o uso de um promotor responsivo à p53 para dirigir a expressão do transgene contido no vetor viral. Começando com vetores retrovirais, foi mostrado que o promotor responsivo à p53, denominado $\mathrm{PG}$, oferece níveis de expressão do transgene que são até 7 vezes maiores do que o visto com vetor parental (não modificado) (Strauss and Costanzi-Strauss, 2004). Quando o cDNA para p53 foi inserido neste vetor, um mecanismo de retroalimentação positiva foi estabelecido, o que 
promove altos níveis de expressão do p53 e proporciona inibição da proliferação de células tumorais de uma forma mais eficiente do que vista com o vetor parental (Strauss et al., 2005). Também foi mostrado que o retrovírus com expressão responsiva à p53 poderia ser utilizado para a transferência do parceiro funcional do p53, o p19Arf. Neste estudo, foi constatado que o p19Arf exógeno poderia complementar a função do p53 endógeno e proporcionar inibição da proliferação (Merkel et al., 2010). O conceito do vetor com expressão controlada por p53 foi adaptado para vetores adenovirais. Para isto, foi montado um novo promotor responsivo à p53, denominado PGTx $\beta$ (ou simplesmente PG) que foi inserido no vetor adenoviral, gerando os vetores AdPG. Foi mostrado também que este promotor é até 5 vezes mais forte do que o promotor CMV e que este pode ser ativado na presença de p53 funcional (Bajgelman and Strauss, 2008).

Observamos que o vetor adenoviral original, com a fibra nativa do capsídeo sorotipo 5 foi ineficiente em transduzir células B16 (melanoma murino, p53-selvagem, p19Arf deficiente e sem expressão de CAR). Para resolver este problema, introduzimos um vetor retroviral que expressa o receptor adenoviral, CAR. Isto resultou em uma alta eficiência de transdução das células B16mCAR com o vetor adenoviral sorotipo 5. No entanto, este procedimento é inconveniente, não possui relevância clínica e até pode inibir o potencial metastático de células B16 (Yamashita et al., 2007). No tratamento destas células, nosso grupo constatou uma interação significante entre os genes mIFN $\beta$ e p19Arf. Durante estes estudos, células B16mCAR transduzidas com os vetores adenovirais AdPGp19Arf e AdPGmIFN $\beta$ entraram em apoptose dentro de um intervalo de 96 horas, enquanto que a ação isolada destes vetores não proporcionou efeito apoptótico significativo. Em ensaios in vivo, este efeito foi reproduzido e somente os animais com tumores tratados com a combinação de p19Arf e IFN $\beta$ revelaram uma interessante redução no tamanho do tumor devido à morte celular (Merkel et al., 2013). 
Já que o procedimento para forçar a expressão de CAR é inconveniente, o grupo do pesquisador Mizuguchi demonstrou que a transdução de células CAR-negativas pode ser realizada com vetores adenovirais contendo modificações na fibra do capsídeo, com incorporação de um tripeptídeo RGD (arginina-glicina-ácido aspártico) (Mizuguchi et al., 2001). A partir disso, obtivemos o vetor AdRGD portador de cDNA de LacZ e confirmamos que este vetor é realmente capaz de transduzir células B16 eficientemente. Além disso, a utilização de um vetor bicistrônico pode ser mais eficaz que a combinação de dois vetores portadores de apenas um gene cada, possivelmente porque o vetor bicistrônico assegura a entrada de ambos os genes nas células-alvo e evita uma possível interferência entre as atividades de dois promotores fortes. Por estes motivos, foi realizada a montagem dos novos vetores Ad_RGD_PG-p19Arf, Ad_RGD_PGmIFN $\beta$ e o vetor controle Ad_RGD_PG-eGFP, que apresentam aprimoramento na transdução, aperfeiçoamento de sua expressão e uma combinação de transgenes que induzem morte celular e, possivelmente, uma resposta imune antitumoral nas células de melanoma murino, B16 (Ribeiro A.H., LVV, dissertação de mestrado e dados não publicados).

Levando em consideração de que a proteína p19Arf participa na inibição da angiogênese diminuindo e inibindo o fator VEGF por via dependente e independente de p53, ou afetando diretamente o fator HIF-1 $\alpha$, que é um importante fator angiogênico responsável pela produção de VEGF (Gerhardt et al., 2003), juntamente com a proteína INF $\beta$, possuidora de atividade anti-angiogênica por inibição de fatores angiogênicos como VEGF e bFGF, ou atuando diretamente na indução de morte de CEs por apoptose, propomos avaliar a influência do tratamento das duas proteínas diretamente nas CEs e seu efeito na vasculatura. 


\section{OBJETIVO}

\subsection{Objetivos gerais}

Investigar a ação da transferência gênica de INF $\beta$ e p19Arf mediada por vetores adenovirais sobre a linhagem celular endotelial tEnd no melanoma murinho, em ensaios in vitro.

\subsection{Objetivos específicos}

I. Avaliar o efeito da transferência gênica com os vetores adenovirais expressando IFN $\beta$ e/ou p19Arf na linhagem tEnd.

II. Avaliar o efeito parácrino/bystander direcionado para a linhagem tEnd na cocultura, com a linhagem B16 previamente transduzida com vetores adenovirais que expressam IFN $\beta$ e/ou p19Arf.

III. Avaliar a expressão de marcadores angiogênicos pela técnica de RT-qPCR, da linhagem tEnd após transdução com os vetores adenovirais portadores de IFN $\beta$ e/ou p19Arf. 


\section{MATERIAL E MÉTODOS}

\subsection{Linhagens celulares}

Foram utilizadas as linhagens de melanoma murino B16 e TM1 e as linhagens de células endoteliais tEnd e tEndTO (linhagem derivada da tEnd, modificada no Laboratório de Vetores Virais por vetores lentivirais para expressar constitutivamente a proteína tomato, fluorescente vermelha). As linhagens B16 e TM1 são linhagens amplamente usadas pelo nosso grupo de pesquisa e estas linhagens foram obtidas por meio de doação ou pelo ATCC e a linhagem tEnd é uma linhagem endotelial derivada de timo (Williams et al., 1988) gentilmente cedida pela pesquisadora Dra. Cristina Maria Fernandes do Instituto Butantã. A linhagem tEnd está apta para serem realizados ensaios angiogênicos (Drewes et al., 2015; Ghigo et al., 1995). A linhagem HEK293A (Human Embrionic Kidney 293) foi usada para produção dos vetores adenovirais recombinantes.

\subsection{Cultivo celular}

As linhagens celulares B16, tEnd, tEndTO foram cultivadas em meio RPMI (Life Technologies) acrescidos de 5\% de FBS (Life Technologies) e 1\% de Anti-Anti (Gibco), mantidas a $37^{\circ} \mathrm{C}$ em atmosfera úmida com $5 \%$ de $\mathrm{CO}_{2}$, a linhagem HEK293A foi cultivada nas mesmas condições descritas, porém utilizando DMEM (Life Technologies). 


\subsection{Vetores adenovirais}

Para a transferência dos genes de camundongo IFN $\beta$ e p19Arf diretamente nas células tumorais, foram utilizados vetores adenovirais não replicativos, nos quais a expressão do transgene é controlada pelo promotor responsivo à p53. Estes vetores também contêm a fibra do capsídeo modificada com a inserção do tripeptídeo RGD, que proporciona a transdução de um amplo espectro de células alvo (Mizuguchi et al., 2001). Todos os vetores AdRGDPG foram desenvolvidos durante o mestrado de Aline Hunger Ribeiro (Processo FAPESP 2008/55963-0).

- Ad_RGD_PG-eGFP (Ad-GFP): Vetor controle que expressa eGFP ( Proteína fluorescente verde).

- Ad_RGD_CMV-LacZ (Ad-LacZ): Vetor controle que expressa a proteína $\beta$ galactosidase, gentilmente cedido pelo Hiroyuki Mizuguchi, National Institute of Health Sciences, Tokyo, Japan.

- Ad_RGD_PG-IFN $\beta$ (Ad-IFN): Vetor usado para expressão da proteína IFN $\beta$ murina.

- Ad_RGD_PG-p19Arf (Ad-p19): Vetor usado para expressão da proteína p19Arf.

- Lego-iT2: Vetor Lentiviral utilizado para inserir constitutivamente a proteína fluorescente tomato(Vermelha), gentilmente cedido por Kristoffer Reicken,University Medical Center, Hamburg, Germany. 


\subsection{Produção e titulação dos vetores adenovirais}

Os vírus foram produzidos em células HEK293A, infectadas com os vetores adenovirais até exibirem efeito citopático, o que indicou o momento certo para lisar as células. Este lisado bruto, contendo as partículas virais, foi aplicado em uma gradiente de iodixanol para ultracentrifugação. Após a centrifugação, forma-se uma banda clara que é removida e aplicada em colunas PD-10 desalting contendo resina Sephadex ${ }^{\mathrm{TM}} \mathrm{G}$ 25 (GE), a partir do qual o vírus foi eluido e aliquotado. Posteriormente, as alíquotas foram armazenadas a $-80^{\circ} \mathrm{C}$ e o estoque de vírus purificado foi titulado com o kit Adeno-X Rapid Titer (Clontech).

\subsection{Transdução adenoviral}

Para transduzir as células, os vírus foram diluídos no meio de cultura RPMI ou DMEM com 5\% de FBS e colocados junto com as células. O MOI (multiplicidade de infecção) e o tempo de tratamento foram usados de acordo com o experimento.

\subsection{Eficiência de transdução pelo vetor Ad-GFP}

Para comparar a eficiência de transdução entre as linhagens tumorais B16, TM1 com a linhagem de células endoteliais tEnd, foi realizado uma ensaio de curva de eficiência de transdução onde a expressão de GFP foi medida por citometria de fluxo. Para isto, foi utilizado o vetor Ad-GFP e as linhagens foram transduzidas com MOIs de 50, 100, 150 e 200 e cultivados por 24 horas. As células foram recolhidas e fixadas com 
paraformaldeido $2 \%$, para posterior avaliação por citometria de fluxo para averiguarmos a porcentagem de células positivas para o GFP.

\subsection{Ensaio de ELISA (Enzyme Linked Immunosorbent Assay) para a detecção da} expressão de IFN $\beta$

Para detecção da expressão de IFN $\beta, 5.10^{4}$ células das linhagens, B16 e tEnd foram semeadas por poço, transduzidas com MOI de 200 e após 24 horas os meios de cultura da linhagens B16 e tEnd foram recolhidos. Os ensaios foram realizados segundo protocolo do fabricante (PBL Biomedical) e a absorbância (450nm) foi determinada pelo leitor de microplacas Victor ${ }^{\mathrm{Tm}}$ (Perkin-Elmer-EUA).

\subsection{Imunofluorescência para detecção da expressão de p19Arf}

Para a detecção da expressão da proteína p19Arf, as linhagens celulares B16 e tEnd foram transduzidas pelos vetores com MOI de 200 e cultivados por 24 horas, fixadas em metanol, permeabilizadas com PBS $1 \mathrm{X}+$ nonidet p40 0,1\% e incubadas com o anticorpo primário (policlonal anti p19Arf produzido em coelho - Calbiochem) diluído em PBS $1 \mathrm{X}+$ albumina $1 \%$ por 1 hora. As células foram lavadas com PBS 1x por 3 vezes, em seguida as células foram incubadas com o anticorpo secundário (IgG anti-coelho produzido em cabra conjugado com Alexa Fluor 488 - Invitrogen) por 1 hora e então coradas com o marcador nuclear DAPI (BD Bioscience) e montadas as lâminas permanentes, as imagens foram capturadas pelo microscópio de fluorescência EVOS. 


\subsection{Ensaio de $\beta$-galactosidase}

A linhagem tEnd foi transduzida pelo vetor adenoviral portador do transgêne LacZ, após 24 horas de tratamento as células foram fixadas com tampão de fixação (2\% paraformaldeído e 0,2\% de glutaraldeído) por 5 minutos, a solução de fixação foi retirada, as células lavadas com PBS $1 \mathrm{X}$ e adicionado o corante $\beta$-gal $\left(\mathrm{NaPO}_{4}, \mathrm{MgCl}_{2}\right.$, $\mathrm{K}_{4}\left[\mathrm{Fe}(\mathrm{CN})_{6}\right],\left(\mathrm{K}_{3} \mathrm{Fe}(\mathrm{CN})_{6}\right.$ e $\left.\mathrm{X}-\mathrm{Gal}\right)$ por 16 horas em temperatura controlada de $37^{\circ} \mathrm{C}$, os poços foram fotografados pela câmera associada ao microscópio. As fotos forem feitas com aumento de 10x.

\subsection{Estabelecimento de linhagem tEndTO pelo vetor lentiviral Lego-iT2}

As células da linhagem tEnd foram transduzidas em placas de 6 poços com o vetor lentiviral Lego-iT2 com MOI de 1, em uma solução substrato contendo meio de cultivo RPMI $10 \%$ FBS e polibreno $(800 \mu \mathrm{g} / \mathrm{mL})$ por 24 horas. Após a primeira parte de transdução com os vetores, iniciou-se a fase de identificação e separação dos clones marcados. As células foram transferidas para placas de $10 \mathrm{~cm}$ para podermos observar as regiões da placa onde haveria a presença da marcação fluorescente vermelha (tomato+), essas áreas foram tripsinizadas e transferidas para outra placa de $10 \mathrm{~cm}$, esse processo foi feito até que toda a placa estivesse identificada pela marcação. O segundo passo para separação dos clones foi diluir as células em meio de cultivo para obter 1 célula para cada $100 \mu \mathrm{L}$ de meio de cultivo, após fazer a diluição, colocamos $100 \mu \mathrm{L}$ dessa diluição em cada placa de 96 poços e selecionamos os poços que estivesse com a presença de uma célula marcada e excluímos os poços com quantidade de células superiores a 1 célula ou sem a presença destas células, então esses poços selecionados foram 
cultivados até que a confluência de células fosse alta para transferir para placas de 6 poços. Com os clones estabelecidos, escolhemos o clone que apresentasse a melhor fluorescência no microscópio EVOS.

\subsection{Produção de meio condicionado}

As células da linhagem B16 (5.10 ${ }^{4}$ células) foram transduzidas em placas de 12 poços pelos vetores adenovirais; Ad-GFP, Ad-IFN, Ad-p19 e a co-transdução AdIFN+Ad-p19 com MOI de 300 por 6 horas, após esse período foram lavadas por 4 vezes com PBS 1x para retirar os vetores não incorporados, então foi adicionado um novo meio que foi mantido por 48 horas, esse meio foi centrifugado por 3000 rpms por 10 minutos para retirada de possíveis células e restos celulares, congelado no freezer -80 . Através desse processo, produzimos os meios condicionados; mc-B16-Controle, mcB16-GFP, mc-B16-IFN, mc-B16-p19 e mc-B16-IFN+p19.

\subsection{Ensaio de Migração}

Para avaliar a taxa de migração das células endoteliais após tratamento com os vetores adenovirais portadores dos transgênes IFN $\beta$ e p19Arf, $5.10^{4}$ células da linhagem tEnd foram plaqueadas nos poços de placas de 12 poços, 24 horas após serem semeadas, foram transduzidas com os vetores por 6 horas e então foi feito um risco na monocama de células da parte superior até a região inferior do poço com um ponteira de $10 \mu \mathrm{L}$. Foi adicionado o composto Mitomicina C (composto anti-proliferativo na concentração 0,02mg/mL), foram tiradas fotos dos poços com microscópio EVOS nos tempos 0h e 24 horas após o risco. A área de cobertura do risco foi aferida pelo programa Zeiss LSM 
Image Browser, após o calculo da área média de 4 pontos do risco de cada tratamento, os dados foram calculados para a porcentagem de cobertura do risco pela seguinte formula: $\left(\left(\mathbf{M}_{\mathbf{0}}-\mathbf{M}_{\mathbf{2 4}}\right) / \mathbf{M}_{\mathbf{0}}\right) * \mathbf{1 0 0}=\mathbf{X}$, onde $\mathbf{M}_{\mathbf{0}}$ é a média da área da migração no tempo 0 hora e $\mathbf{M}_{24}$ é a média da área da migração no tempo 24 horas e $\mathbf{X}$ é a porcentagem de cobertura de risco. Após calcularmos a taxa de migração os dados foram normalizados pelo controle pela seguinte formula: $\mathbf{T}_{\mathbf{T}} / \mathbf{T}_{\mathbf{C}} * \mathbf{1 0 0}=\mathbf{X}$, onde o $\mathbf{T}_{\mathbf{C}}$ é a porcentagem de cobertura do risco do grupo controle, $\mathbf{T}_{\mathbf{T}}$ é a porcentagem de cobertura do risco do grupo tratado e $\mathbf{X}$ é a porcentagem de cobertura de risco normalizado pelo controle.

\subsection{Ensaio de Tubologênese}

Para avaliar a influência do tratamento na formação de tubos pela linhagem endotelial tEnd, foi realizado ensaio de tubologênese no Matrigel (BD Biosciences). O Matrigel foi diluído para duas vezes em meio de cultivo comum, colocado no fundo dos poços de placas de 12 poços, estes poços foram incubados na estufa a $37^{\circ} \mathrm{C}$ até a matriz solidificar, então foi adicionado meio de cultivo enriquecido com $4 \%$ de Matrigel e $10^{4}$ células da linhagem tEnd previamente transduzidas pelos vetores por 6 horas foram semeadas nesses poços. Para analise do ensaio foram tiradas fotos das regiões de formação de tubos 48 horas após as células serem semeadas e a quantidade de tubos foi quantificada, levando em consideração um tamanho padrão e a formação de tubos com mais de 2 células sem que o tubo estivesse deformado. 


\subsection{Ensaio de citotoxicidade - MTT}

Foram plaqueadas $2.10^{3}$ células da linhagem tEnd por poço na placa de 96 poços, as células foram transduzidas com MOI de 200 ou tratadas com meio condicionado por 48 horas, após esse período de tratamento foi adicionado $20 \mu \mathrm{L}$ da

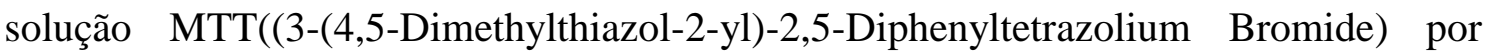
poço e incubados por 4 horas, logo em seguida $100 \mu \mathrm{L}$ da Solução de Solubilização(20\% SDS e, 50\% DMF, pH 4,7) foram adicionados e incubado por 16 horas em estufa a $37^{\circ} \mathrm{C}$, a placa foi levada para o espectrofotômetro para ler a absorbância no comprimento de onda de $570 \mathrm{~nm}$.

\subsection{Ensaio de proliferação}

Para avaliar a taxa de proliferação da linhagem endotelial tEnd transduzidas com os vetores, $2.10^{3}$ células foram plaqueadas em placas de 96 poços e transduzidas com MOI de 200. Para a análise, quatro fotos no aumento de 10x foram feitas para cada poço, pelo microscópio EVOS, nos tempos 0h (poucos minutos antes da transdução) e 24 horas após a transdução. Na figura $\mathbf{0 8}$, os campos onde foram tirados as fotos. A formula usada para calcular a taxa de proliferação foi: $\mathbf{M}_{\mathbf{T}} / \mathbf{M}_{\mathbf{C}}=\mathbf{X}$, onde $\mathbf{M}_{\mathbf{T}}$ é média de células do campo tratado no tempo 24 horas, $\mathbf{M}_{\mathbf{C}}$ é a média de células do campo controle em 24 horas e $\mathbf{X}$ é a taxa de proliferação. 


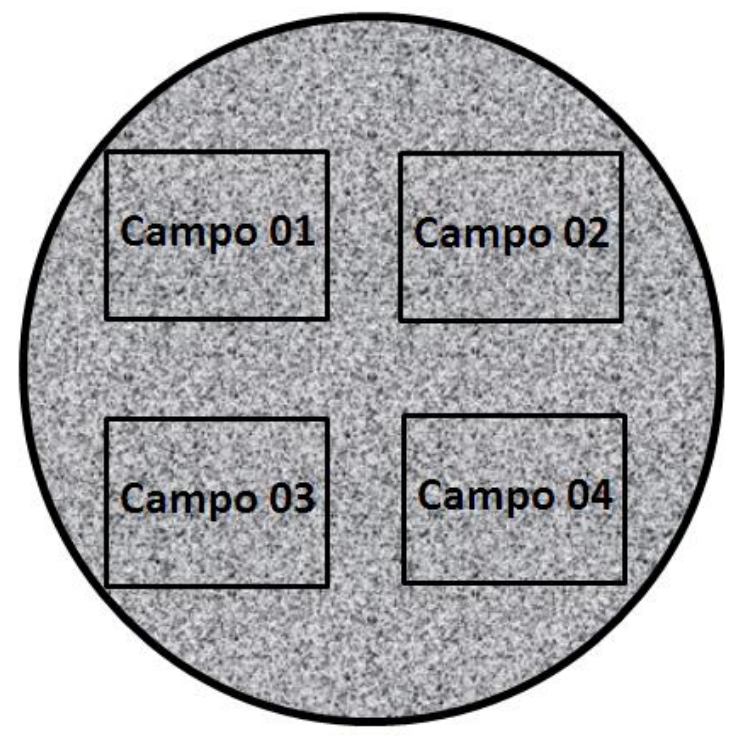

Figura 8: Representação da localização dos quatro campos onde foram tiradas as fotos das células na placa de 96 poços.

\subsection{Ensaio clonogênico}

Para realizarmos o ensaio clonogênico, $2.10^{4}$ células da linhagem tEnd foram ransduzidas pelos vetores adenovirais com MOI de 200 por 6 horas, após esse período estas foram lavadas e 1000 células de cada tratamento foram semeadas em placas de 10 cm com $10 \mathrm{~mL}$ de meio, após 10 dias, as placas foram lavadas com PBS 1X, fixadas com solução 1:1 metanol e ácido acético diluído para 1:3 em água destilada por 5 minutos, coradas com azul de tripan por 5 minutos. $\mathrm{O}$ ensaio também foi realizado utilizando o meio condicionado como tratamento para a linhagem tEnd, onde 300 células foram semeadas junto com $1 \mathrm{~mL}$ de meio condicionado diluído pela metade com meio comum em placas de 6 poços, após 10 dias os poços foram fixados e corados como descrito acima. Após serem coradas as colônias foram quantificadas. 


\subsection{Ensaio de Migração}

Para avaliar a taxa de migração das células endoteliais após tratamento com os vetores adenovirais portadores dos transgênes IFN $\beta$ e p19Arf, 5.10 4 células da linhagem tEnd foram plaqueadas nos poços de placas de 12 poços, 24 horas após serem semeadas, foram transduzidas com os vetores por 6 horas e então foi feito um risco na monocama de células da parte superior até a região inferior do poço com um ponteira de $10 \mu \mathrm{L}$. Foi adicionado o composto Mitomicina C (composto anti-proliferativo na concentração 0,02mg/mL), foram tiradas fotos dos poços com microscópio EVOS nos tempos 0h e 24 horas após o risco. A área de cobertura do risco foi aferida pelo programa Zeiss LSM Image Browser, após o calculo da área média de 4 pontos do risco de cada tratamento, os dados foram calculados para a porcentagem de cobertura do risco pela seguinte formula: $\left(\left(\mathbf{M}_{\mathbf{0}}-\mathbf{M}_{\mathbf{2 4}}\right) / \mathbf{M}_{\mathbf{0}}\right)^{*} \mathbf{1 0 0}=\mathbf{X}$, onde $\mathbf{M}_{\mathbf{0}}$ é a média da área da migração no tempo 0 hora e $\mathbf{M}_{24}$ é a média da área da migração no tempo 24 horas e $\mathbf{X}$ é a porcentagem de cobertura de risco. Após calcularmos a taxa de migração os dados foram normalizados pelo controle pela seguinte formula: $\mathbf{T}_{\mathbf{T}} / \mathbf{T}_{\mathbf{C}} * \mathbf{1 0 0}=\mathbf{X}$, onde o $\mathbf{T}_{\mathbf{C}}$ é a porcentagem de cobertura do risco do grupo controle, $\mathbf{T}_{\mathbf{T}}$ é a porcentagem de cobertura do risco do grupo tratado e $\mathbf{X}$ é a porcentagem de cobertura de risco normalizado pelo controle.

\subsection{Ensaio de Tubologênese}

Para avaliar a influência do tratamento na formação de tubos pela linhagem endotelial tEnd, foi realizado ensaio de tubologênese no Matrigel (BD Biosciences). O Matrigel foi diluído para duas vezes em meio de cultivo comum, colocado no fundo dos poços de placas de 12 poços, estes poços foram incubados na estufa a $37^{\circ} \mathrm{C}$ até a matriz 
solidificar, então foi adicionado meio de cultivo enriquecido com $4 \%$ de Matrigel e $1.10^{4}$ células da linhagem tEnd previamente transduzidas pelos vetores por 6 horas foram semeadas nesses poços. Para analise do ensaio foram tiradas fotos das regiões de formação de tubos 48 horas após as células serem semeadas e a quantidade de tubos foi quantificada, levando em consideração um tamanho padrão e a formação de tubos com mais de 2 células sem que o tubo estivesse deformado.

\subsection{Ensaio de ciclo celular}

A linhagem tEnd $\left(1.10^{4}\right.$ células) foi transduzida diretamente com os vetores adenovirais ou tratadas com o meio condicionado, cultivada por 48 horas, fixadas em etanol 70\%. Para a análise, as células foram tratadas com Iodeto de Propídeo (P.I) na concentração de $10 \mu \mathrm{g} / \mu \mathrm{L}$, a solução foi incubada por 15 minutos. A fluorescência foi medida por meio do citômetro de fluxo Attune (Life Technologies) e analisada pelo programa do próprio equipamento Attune ${ }^{\circledR}$ Cytometric Software.

\subsection{Ensaio de marcação de células apoptóticas por Anexina-V}

As células da linhagem tEnd $\left(1.10^{4}\right.$ células) foram transduzidas diretamente com os vetores adenovirais ou tratadas com o meio condicionado e após 48 horas foram coletas junto com o sobrenadante, as células foram contadas e $1.10^{5}$ células foram centrifugadas por $400 \mathrm{G}$ por 5 minutos, ressuspendidas com tampão de ligação de anexina (10mM HEPES, $140 \mathrm{mM} \mathrm{NaCl}, 2,5 \mathrm{mM} \mathrm{CaCl}, \mathrm{pH} 7,4)$ e foi acrescentado $5 \mu \mathrm{L}$ de AnexinaV-alexa 488 (Life Technologies) e $1 \mu \mathrm{L}$ de P.I na concentração de $10 \mu \mathrm{g} / \mu \mathrm{L}$, a solução foi incubada por 15 minutos a $37^{\circ} \mathrm{C}$, em seguida adicionou-se $400 \mu \mathrm{L}$ do 
tampão de ligação da anexina e as amostras foram analisadas por citometria de fluxo no equipamento Attune (Life Technologies).

\subsection{Ensaio de expressão gênica}

As células da linhagem tEnd $\left(5.10^{4}\right)$ foram transduzidas com os vetores por 24 horas, coletadas e lisadas com Trizol (Life technologies), em seguida adicionamos clorofórmio para cada $1 \mathrm{~mL}$ de Trizol utilizado, esta solução foi centrifugada a $12000 \mathrm{~g}$ por 15 minutos, recolhemos a fase aquosa contendo o RNA, adicionamos o isopropanol e centrifugamos novamente a 12000 g por 15 minutos, retiramos a solução mantendo o precipitado de RNA, o precipitado foi lavado com etanol 75\%, centrifugado $7500 \mathrm{~g}$ por 10 minutos, o sobrenadante foi descartado e o RNA deixado a temperatura ambiente até secar e ressuspendido em água Milli-Q. Para realizar a transcrição reversa do RNA extraído, o RNA foi quantificado, incubado a primeira vez a $65^{\circ} \mathrm{C}$ por 5 minutos no termociclador com Randon Primers e dNTP, na segunda incubação foi adicionado as soluções First Strand Buffer e DTT por 2 minutor a $37^{\circ} \mathrm{C}$ e por ultimo fizemos a reação da transcrição reversa adicionando a enzima MMLV(Thermo Fisher). A fase de amplificação foi feita com 15 minutos a $95^{\circ} \mathrm{C}, 40$ ciclos de 15 segundos a $95^{\circ} \mathrm{C}$ para desnaturação, anelamento por 1 minuto a $60^{\circ} \mathrm{C}$ e extensão por 1 minuto a $72^{\circ} \mathrm{C}$. As triplicatas foram analisadas pelo 7500 Fast Software 2.05 (Applied Biosytems). Os primers (Tabela 1), desenhados para RT-qPCR, foram feitos usando software Primer3. Os primers foram desenhados em exons diferentes. Para evitamos produtos não específicos foi realizado a análise no site www.ncbi.nlm.nih.gov/blast. Três genes de referência foram testados (Cyclo, GAPDH e $\beta$-actina), a $\beta$-actina foi escolhida por ser a mais estável entre as amostras. A eficiência dos primers foi avaliada para próxima de 
$100 \%$ de eficiência. O método $2^{-\Delta \Delta \mathrm{Ct}}$ foi usado para quantificar a expressão relativa dos genes, os dados foram apresentados em Fold change in expression comparado com células transduzidas com o vetor controle Ad-GFP.

Tabela 1: Tabela com as sequências de bases dos oligonucleotídeos, pró-angiogênico e genes relacionado com a via de p53 e morte celular, o gene referência $\beta$-actina.

\begin{tabular}{|c|c|c|}
\hline Gene & $\begin{array}{c}\text { Primer Forward } \\
5^{\prime}-3^{\prime}\end{array}$ & $\begin{array}{c}\text { Primer Reverse } \\
5^{\prime}-3^{\prime}\end{array}$ \\
\hline & Genes pró-angiogênicos & \\
\hline VEGF-A & CCTTCGTCCTCTCCTTACC & ACACACAGCCAAGTCTCC \\
\hline bFGF & AAGCCCAAACTGCTCTACTG & CCCTTTATATACACTTCGCCCG \\
\hline ANG-2 & CATTCTTCGCTGCCATTCTG & GCACATTGCCCATGTTGAATC \\
\hline $\begin{array}{l}\text { VE- } \\
\text { Caderina }\end{array}$ & CAGCAACTTCACCCTCATAAAC & TCCCGATTAAACTGCCCATAC \\
\hline HIF-1a & CATGATGGCTCCCTTTTTCA & GTCACCTGGTTGCTGCAATA \\
\hline & Genes da via de p53 & \\
\hline MDM2 & GCAGTGAATCTACAGGGACGC & ATCCTGATCCAACCAATCACC \\
\hline p53 & GACAGCAGGGCTCACTCCAGCTAC & GGACGGGATGCAGAGGCAGTCA \\
\hline $\mathrm{p} 21$ & TGGTGTCTGAGCGGCCTGAAGA & TCCCGTGGGCACTTCAGGGT \\
\hline PUMA & GAGCGGCGGAGACAAGAAGAGC & AGGATCCCTGGGTAAGGGGAGGAG \\
\hline & Gene referência & \\
\hline$\beta$-actina & AAGGCCAACCGTGAAAAGAT & GTGGTACGACCAGAGGCATAC \\
\hline
\end{tabular}




\subsection{Co-cultura}

Para realizarmos o ensaio de co-cultura, primeiramente $2.10^{4}$ das células da linhagem B16 foram previamente transduzidas com MOI de 300 e cultivadas por 6 horas com os vetores, lavadas por 4 vezes com PBS 1x para retirarmos os vetores não incorporados, $2.10^{4}$ células da B16 transduzidas foram semeadas com $10^{4}$ células da linhagem tEndTO em placas de 6 poços, colocamos o dobro de células tumorais, pois as células da linhagem tEndTO tem taxa de proliferação duas vezes maior que a linhagem B16 (Dados não publicados). Os poços foram fotografados pelo microscópio de fluorescência EVOS nos tempos, 24, 48, 72 horas após a semeadura das duas linhagens. A análise foi feita pela contagem de células vermelhas ou não aderidas nas placas. Foram tiradas 6 fotos por poço em localizações aleatórias e as células foram quantificadas pelo programa Image J. O calculo da normalização foi feito pela seguinte formula: $\mathbf{N}_{\mathbf{T}} / \mathbf{N}_{\mathbf{C}}=\mathbf{V}$, onde $\mathbf{N}_{\mathbf{T}}$ é a média de células de 6 campos do poço tratado no tempo $\mathrm{X}, \mathbf{N}_{\mathbf{C}}$ é a média de células de 6 campos do poço controle no tempo $\mathrm{X}$, e $\mathbf{V}$ é o calculo da taxa de células do poço tratado normalizado poço controle no mesmo tempo.

\subsection{Análise estatística}

As análises foram feitas pelo software GraphPad Prisma 5. Os testes estatísticos utilizados em cada experimento estão indicados na legenda de cada figura. Os dados foram considerados significativos quando $\mathrm{p}<0,05$. 


\section{RESULTADOS}

\subsection{PRODUCÃ̃O E TITULAĊ̃̃O DOS VETORES ADENOVIRAIS}

Os vetores adenovirais não replicativos utilizados neste projeto; Ad_RGD_PGGFP, Ad_RGD_PG-IFN $\beta$ e o Ad_RGD_PG-p19Arf foram produzidos e titulados utilizando células da linhagem HEK293A como descrito no Material e Métodos. A tabela abaixo mostra a titulação dos vetores, tabela $\mathbf{0 2}$.

Tabela 2: Resultado da titulação biológica dos vetores virais.

\begin{tabular}{|c|c|}
\hline VETOR & Título (TU/ml) ${ }^{\mathrm{a}}$ \\
\hline Ad_RGD_PG-GFP & $6,2.10^{9}$ \\
\hline Ad_RGD_PG-IFN $\beta$ & $2.10^{9}$ \\
\hline Ad_RGD_PG-p19Arf & $1,5.10^{10}$ \\
\hline
\end{tabular}

a: $\mathrm{TU} / \mathrm{ml}$ (TU = unidades transformantes).

\subsection{CARACTERIZACÃO DOS VETORES PELA EXPRESSÃO DO}

\section{TRANSGENE}

Foram realizadas análises qualitativas para identificar a produção dos transgenes GFP, IFN $\beta$, p19Arf e LacZ e assim validar os vetores adenovirais quanto a expressão do transgene. 


\subsubsection{Ensaio para detecção de GFP}

Como primeiro ensaio de validação, iniciamos pelo vetor controle Ad-GFP, onde as linhagens tumorais B16, TM1 e a linhagem endotelial, tEnd foram transduzidas com vetor Ad-GFP com MOI de 50, incubadas por 24 horas, foram fotografadas pelo microscópio de fluorescência EVOS utilizando o filtro para detecção de GFP. Após observação no microscópio de fluorescência as células foram coletadas, fixadas e analisadas por citometria de fluxo para detecção de células positivas para fluorescência do transgene GFP. Na figura 9 mostramos a expressão de GFP mediado pelo vetor AdGFP na linhagem tEnd no microscópio de fluorescência EVOS. Os resultados da citometria de fluxo mostraram na figura $\mathbf{1 0}$ que os vetores adenovirais transduzem eficientemente as células tumorais e também as células endoteliais. Nesse primeiro ensaio, começamos a observar que a linhagem endotelial tEnd demonstra maior capacidade de ser transduzida e expressar o transgêne.

\section{tEnd}

\section{Controle}

Luz comum/488

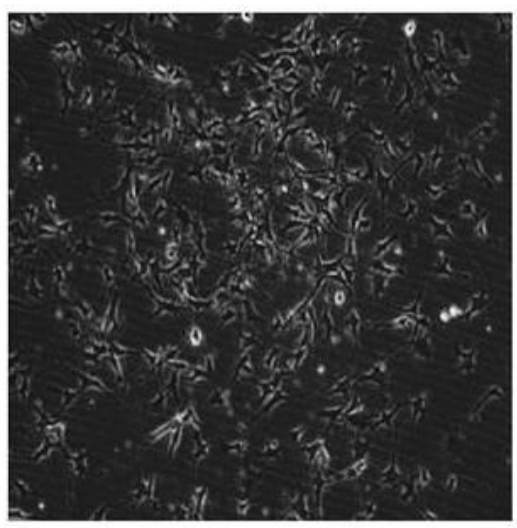

Ad-GFP Luz comum/488

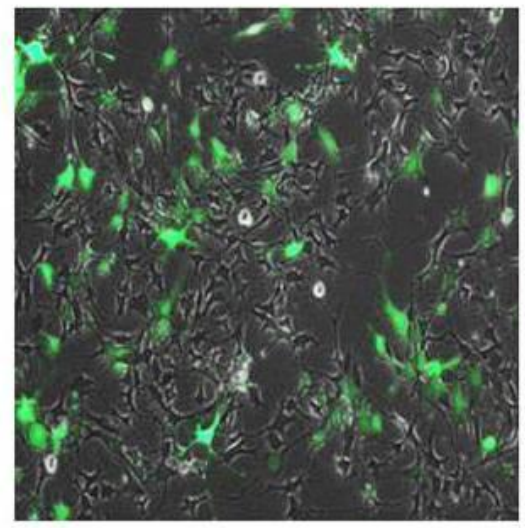

Figura 9: Ensaio de identificação de células tEnd GFP positivas no microscópio EVOS após transdução da linhagem tEnd com o vetor adenoviral Ad-GFP. Imagens feitas pelo microscópio EVOS da linhagem tEnd, 24 horas após transdução com o vetor Ad-GFP. As imagens mostram a sobreposição entre o filtro de $488 \mathrm{~nm}$ e contraste de fase. Objetiva de 10x. 
B16
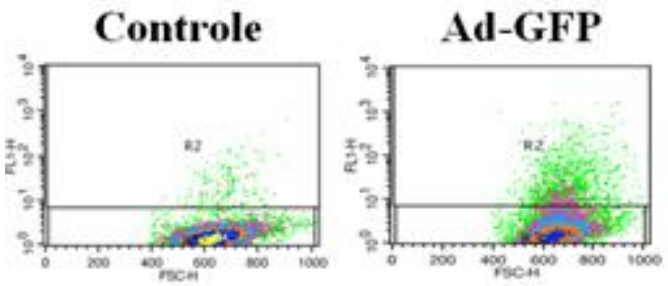

TM1
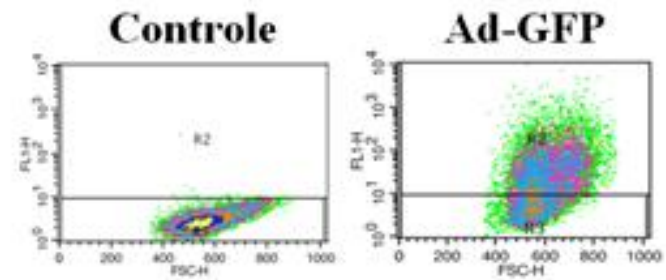

\section{tEnd}

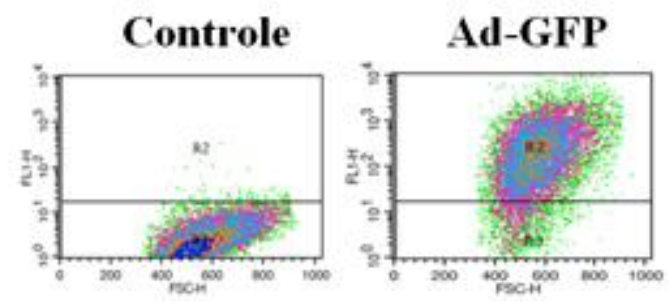

Figura 10: Citometria de fluxo para detecção de células GFP positivas. As linhagens B16, TM1, tEnd e LLC foram transduzidas com vetor Ad-GFP na MOI de 50 e 24 horas após a transdução foram analisadas por citometria de fluxo (FACSCalibur - BD). Os gráficos mostram no eixo das ordenadas a intensidade de fluorescência em FL1-H (filtro no comprimento de onda do GFP) e no eixo das abscissas o Foward scatter (FSC).

\subsubsection{Ensaio para detecção da proteína Interferon-beta}

Ensaio de ELISA para detecção de IFN $\beta$, buscou validar os vetores quanto à expressão da proteína IFN $\beta$ mediada pelos vetores adenovirais. Este ensaio foi realizado na linhagem B16 e tEnd, onde $5.10^{4}$ células em placas de 12 poços foram transduzidas e cultivadas por 24 horas pelos vetores adenovirais com MOI de 200, o meio de cultura proveniente do ensaio foi congelado em freezer $-80^{\circ} \mathrm{C}$ e após uma semana realizou-se o ensaio de acordo com protocolo da empresa (PBL Biomedical) e a absorbância de 450nm foi determinada pelo leitor de microplacas Victor ${ }^{T m}$ (Perkin-Elmer-EUA) . O ensaio mostrou que os vetores portadores do cDNA de IFN $\beta$ conferem produção da proteína interferon-beta nas linhagens B16 e tEnd, figura 11. 


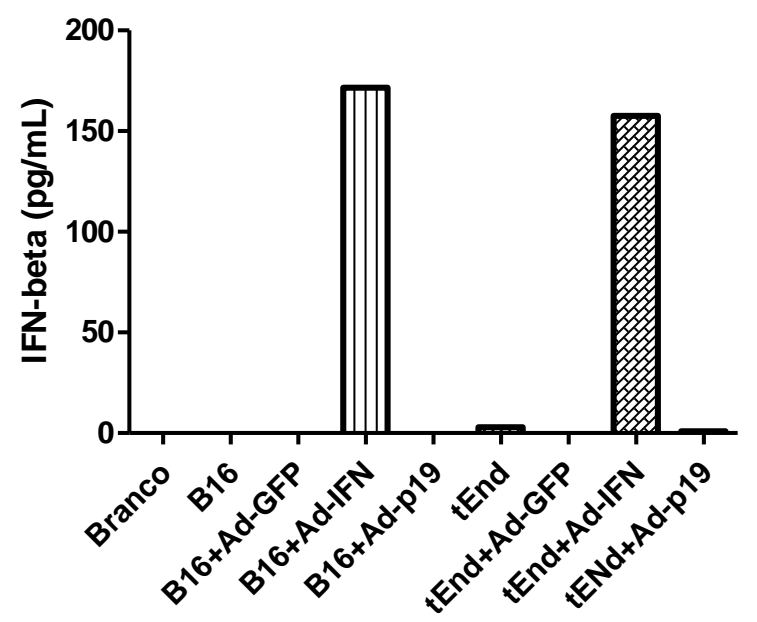

Figura 11: Ensaio de ELISA para INFß da linhagem B16 e tEnd transduzidas com os vetores adenovirais. As linhagens foram transduzidas com os vetores adenovirais com MOI de 200 por 24 horas, o sobrenadante das células foi recolhido e analisado quanto à concentração de INF $\beta$ produzido. Foi realizada leitura de absorbância de 450nm no leitor de microplacas Victor (Perkin-Elmer-EUA ).

\subsubsection{Imunofluorescência para a proteína p19Arf}

Ensaio de detecção de p19Arf nas linhagens B16 e tEnd por imunofluorescência, onde as células foram transduzidas com MOI de 200 pelos vetores adenovais em cima de lamínulas de vidro dentro de placas de 12 poços e cultivadas por 24 horas. Após esse período as células foram fixadas e incubadas com anticorpo contra a proteína p19Arf. As lâminas foram observadas no microscópio EVOS. As células transduzidas com vetor Ad-GFP não fluoresceram no filtro GFP, onde somente o sinal do fluoroforo (Alexa 488) foi detectado, pois a proteína GFP expressa pelo vetor AdGFP é degradada durante a fixação das células no ensaio.

Este ensaio demonstrou que as linhagens B16 e tEnd transduzidas pelos vetores portadores de p19Arf apresentam marcação para o p19Arf, identificada pela fluorescência esverdeada presente no núcleo e citoplasma, figura 12. 


\section{B16 DAPI/488}
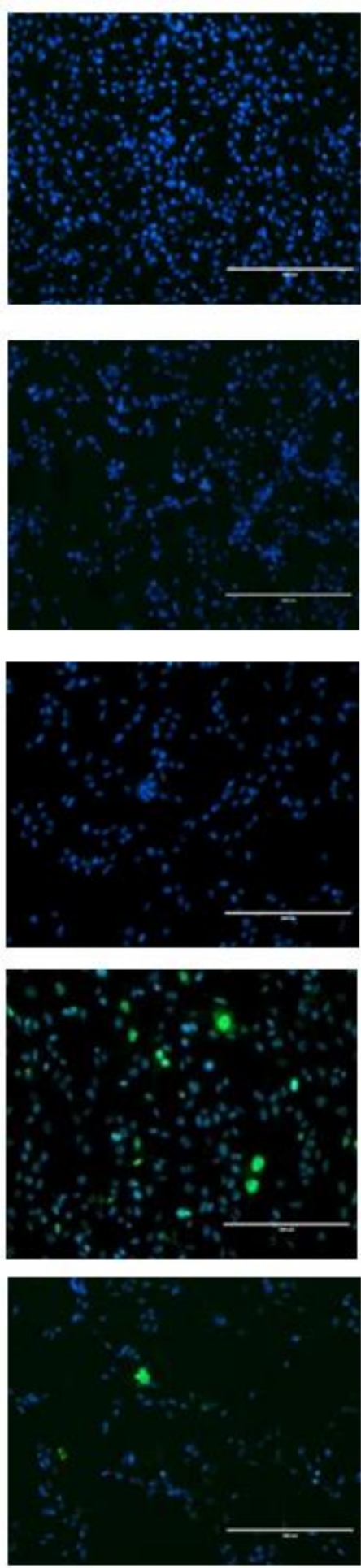
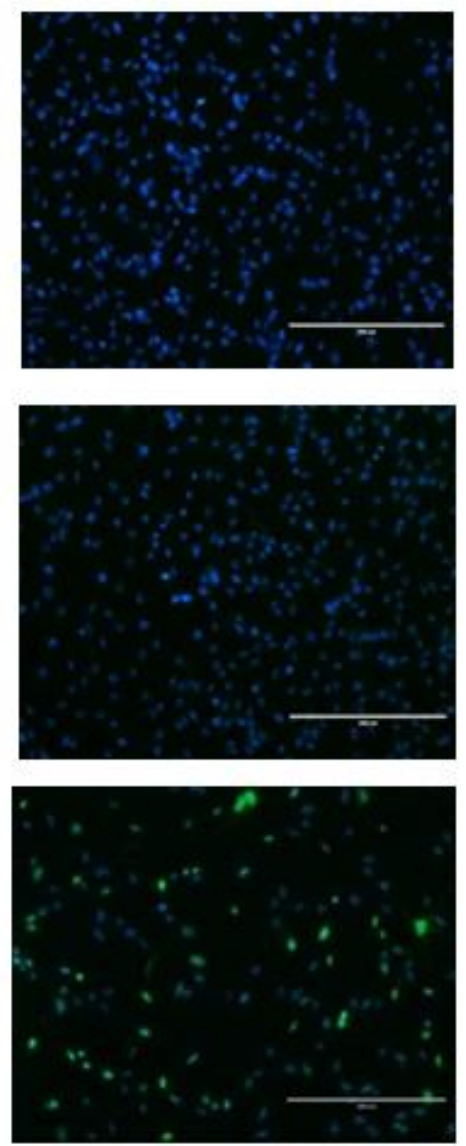

tEnd DAPI/488

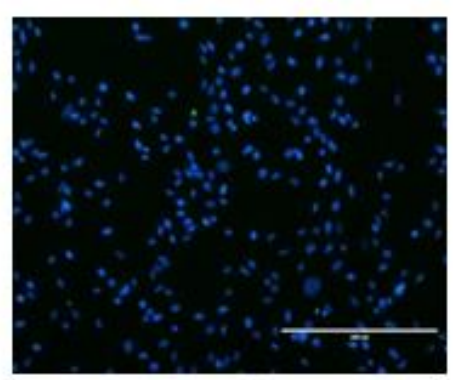

\section{Controle}

Ad-GFP

Ad-IFN

Ad-p19

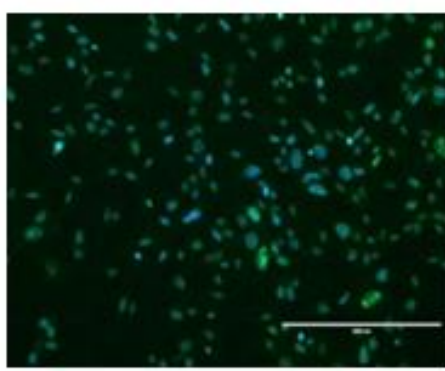

Ad-IFN+

Ad-p19

Figura 12: Ensaio de imunofluorescência para detecção da proteína p19Arf das linhagens B16 e tEnd transduzidas com os vetores adenovirais. As células da linhagem B16 e tEnd foram transduzidas pelos vetores adenovirais com uma MOI de 200 e após 24 horas as células foram fixadas com metanol e incubadas com anticorpo de coelho anti-p19Arf e secundário anti-coelho.conjugado com Alexa 488, os núcleos foram corados com DAPI. As imagens mostram a sobreposição das imagens dos filtros de comprimento de onda de 488nm e o filtro do DAPI. Foram observadas em objetiva de 10x. 


\subsubsection{Ensaio para detecção da $\beta$-galactosidase}

Além do vetor Ad-GFP, exploramos o uso do vetor Ad-LacZ, como um controle para os nossos ensaios. O vetor Ad-GFP não poderia ser utilizado como vetor controle no ensaio de marcação de células apoptóticas por AnexinaV-Alexa 488 e P.I, pois a proteína fluorescente verde emite seu sinal no mesmo comprimento de onda que o marcador Alexa488.

Para detecção de $\beta$-galactosidase, as linhagens B16 e tEnd foram transduzidas com o vetor Ad-LacZ, com MOI de 200, incubadas por 24 horas antes de realizar o ensaio para detecção da atividade de $\beta$-galactosidade, as imagens abaixo mostram que o vetor transduz as células e fornece expressão do transgene, figura 13.

B16
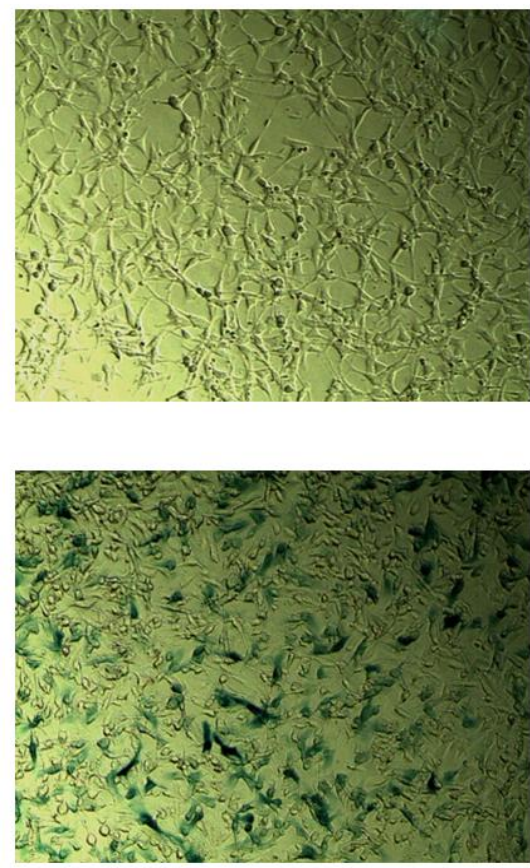

tEnd

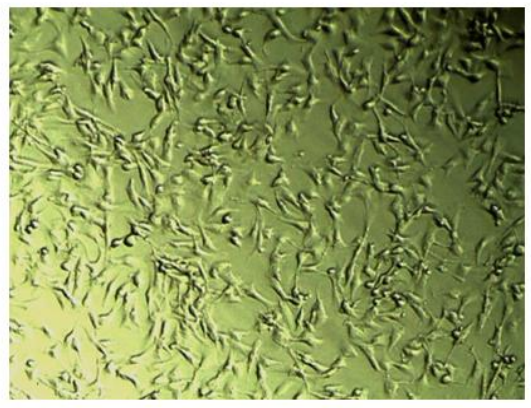

Controle

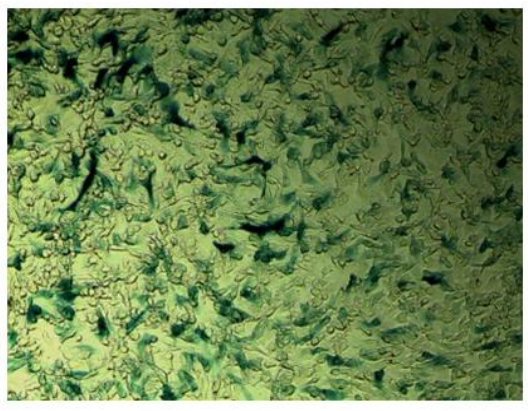

Ad-LacZ

Figura 13: Ensaio para detecção de $\boldsymbol{\beta}$-galactosidase. As linhagens tEnd e B16 foram transduzidas pelos vetores Ad-LacZ com uma MOI de 200 por 24 horas. Em seguida as células foram fixadas e coradas com reagente para detecção da atividade da enzima $\beta$-galactosidade. As imagens foram observadas em objetiva de $10 \mathrm{x}$. 
4.2.5. Ensaio quantitativo da expressão dos transgenes IFN $\beta$ e p19Arf

Para finalizar os ensaios de validação dos vetores terapêuticos, fizemos a análise de expressão relativa pelo RNA mensageiro para os trangenes IFN $\beta$ e p19Arf da linhagem tEnd transduzida com os vetores. Os dados do ensaio de expressão do IFN $\beta$, foram apenas observados nos tratamento com Ad-p19, Ad-IFN e Ad-IFN+Ad-p19, as células transduzidas com o vetor Ad-p19 foram usadas como controle, pois as células do grupo controle e transduzidas com Ad-GFP não demonstrou nenhuma expressão do IFNß. Os dados demonstram que os vetores apresentam expressão relevante dos seus respectivos transgenes, figura 14.
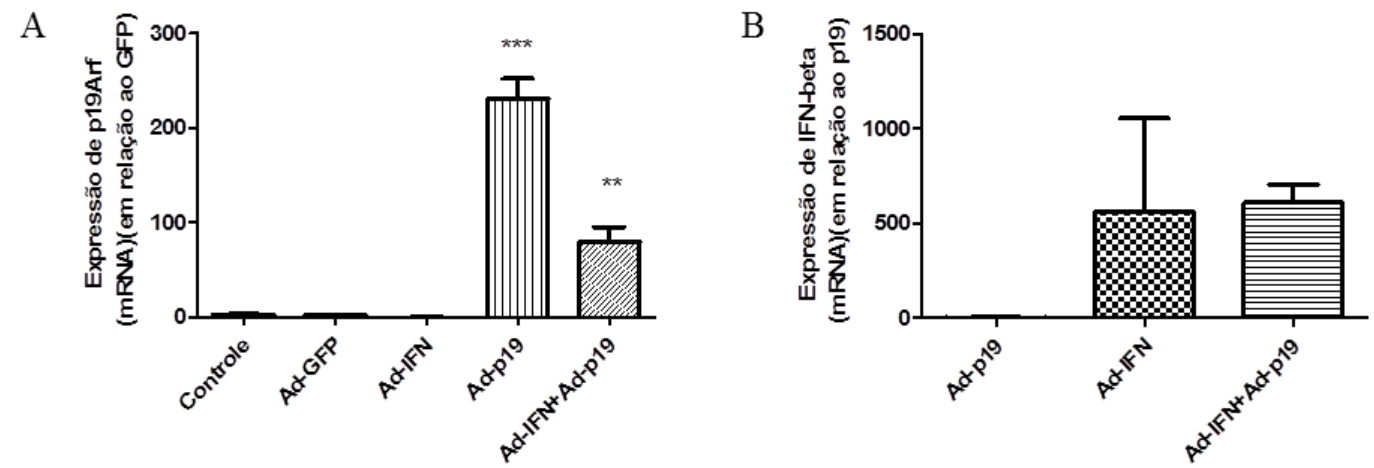

Figura 14: Expressão gênica relativa de IFN $\beta$ e p19Arf da linhagem tEnd transduzida com os vetores adenovirais. (A) As células da tEnd foram transduzidas pelos vetores por 24 horas com MOI de 200. (B) Nesse ensaio foi utilizado como controle as células tEnd transduzidas com o vetor Ad-p19. Os dados representam à média e o desvio padrão de três experimentos independentes. ***p<0,001 e **p<0,01; ANOVA seguido do pós-teste multi-comparativo Tukey. 


\subsection{ENSAIO DE EFICIÊNCIA DE TRANSDUÇÃO E ENSAIOS FUNCIONAIS DO TRATAMENTO COM VETORES ADENOVIRAIS DIRETAMENTE NA LINHAGEM ENDOTELIAL}

\subsubsection{Curva de eficiência de transdução}

Neste ensaio, foi investigado a curva de eficiência de transdução das linhagens tumorais B16, TM1e tEnd com os MOIs de 50, 100, 150 e 200 do vetor Ad-GFP. As células foram transduzidas e analisadas por citometria de fluxo para detectar a porcentagem de células GFP positivas, 24 horas após transdução. O resultado do ensaio mostra que a linhagem tEnd apresenta maior eficiência de transdução dos vetores se comparado com as linhagens de melanoma B16 e TM1, o resultado revelou uma diferença estatisticamente significante indicando que a linhagem endotelial é mais permissiva para transdução com adenovírus do que as linhagens de melanoma, figura 15.

A

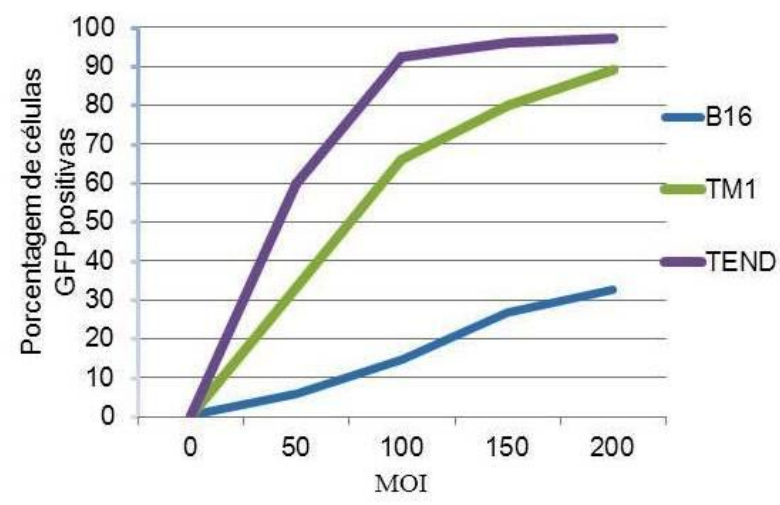

B

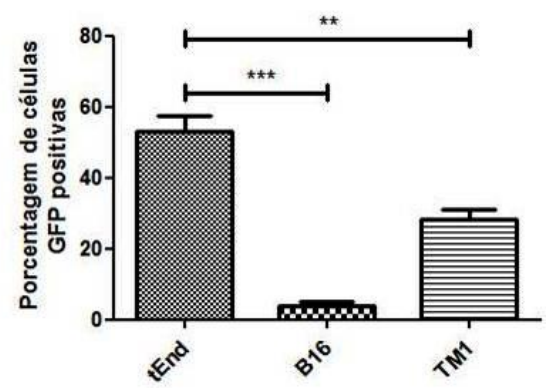

Figura 15: Eficiência de transdução nas linhagens B16, TM1 e tEnd. As células das linhagens B16, TM1 e tEnd foram transduzidas com o vetor Ad-GFP nos MOIs de 50, 100, 150 e 200 e incubado por 24 horas, após esse período estas células foram fixadas e analisadas por citometria de fluxo para detecção de células positivas para GFP. (A) Curva de eficiência de transdução entre as linhagens tEnd, B16 e TM1 em diferentes quantidades de MOIs. (B) Gráfico com a porcentagem de transdução do vetor Ad-GFP no MOI de 50 nas linhagens B16, TM1 e tEnd. Os dados representam à média e o desvio padrão de três experimentos independentes. A análise estatística foi feita pela média de três ensaios independentes. *: p< 0,05 ; o Test $t$ foi o teste estatístico utilizado no ensaio. 


\subsubsection{Ensaio de migração}

Neste ensaio avaliamos a taxa de migração das células da linhagem endotelial tEnd após o tratamento com os vetores adenovirais. O ensaio de migração consiste em criar um espaço vazio (risco) na monocamada de células e esperar que as células migrem com objetivo de fechar o espaço. Durante o processo são tiradas fotos em determinados tempos, estas fotos são usadas para quantificar o fechamento do espaço (Liang et al., 2007; van der Meer et al., 2010).

Neste ensaio, quantificamos a movimentação do tempo 0 hora até 24 horas após transdução. Os dados do ensaio indicam que tratamento com vetores Ad-p19 diminuem a taxa de proliferação, figura 16. 
A

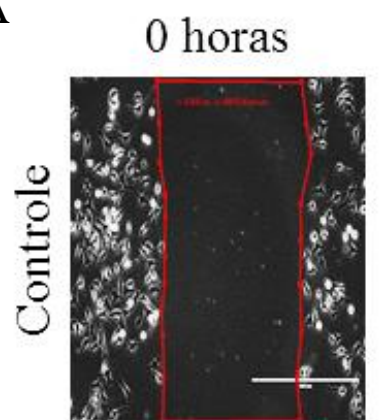

24 horas
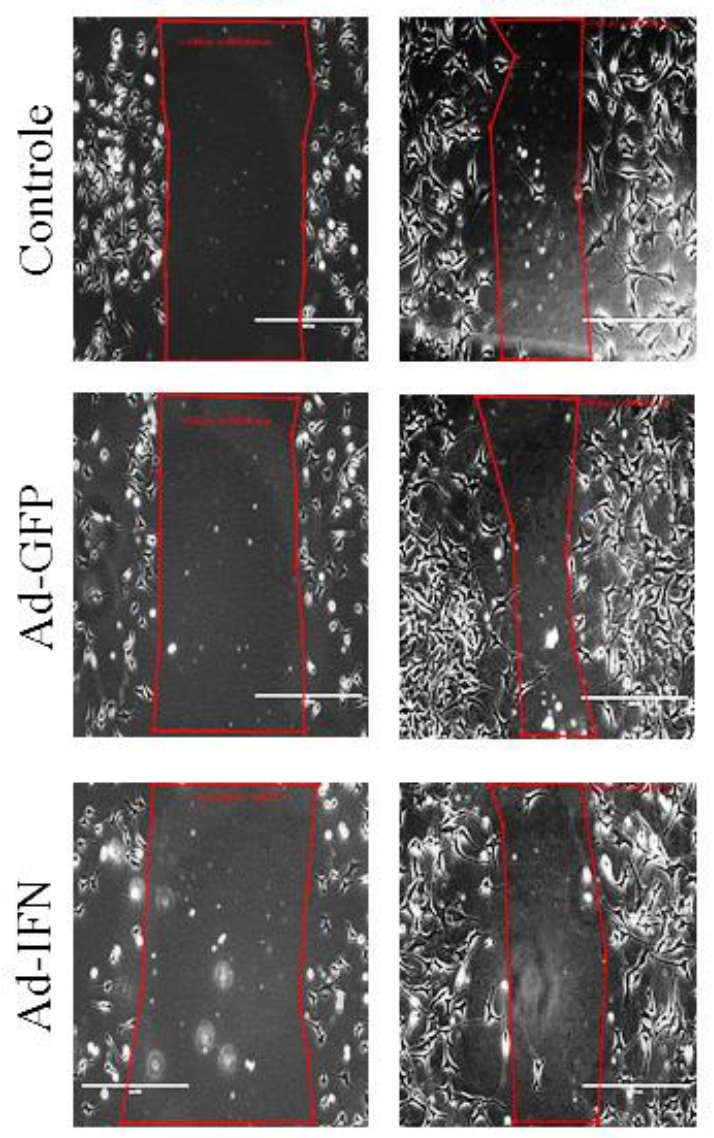

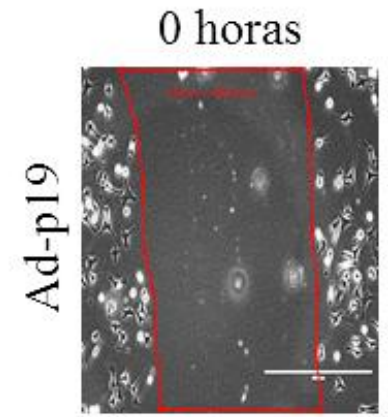

24 horas
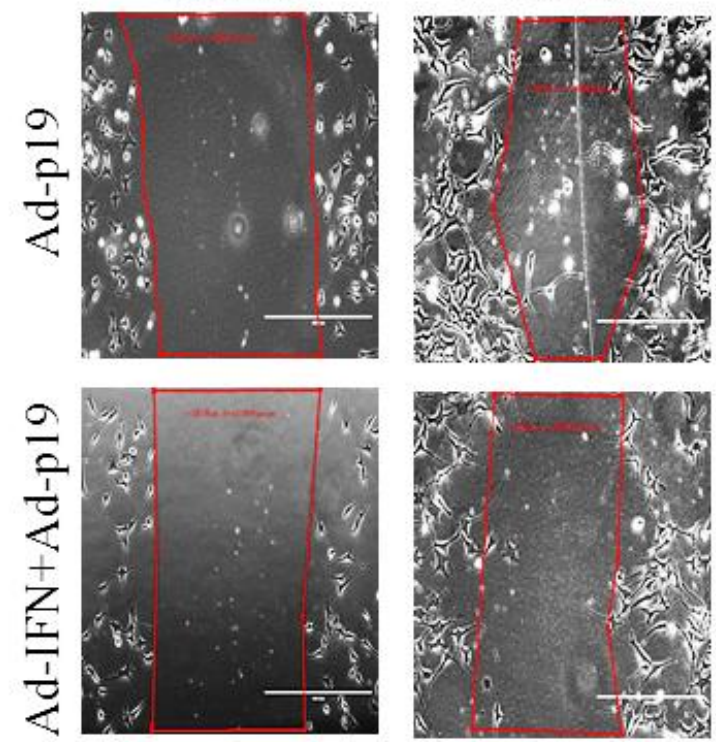

B

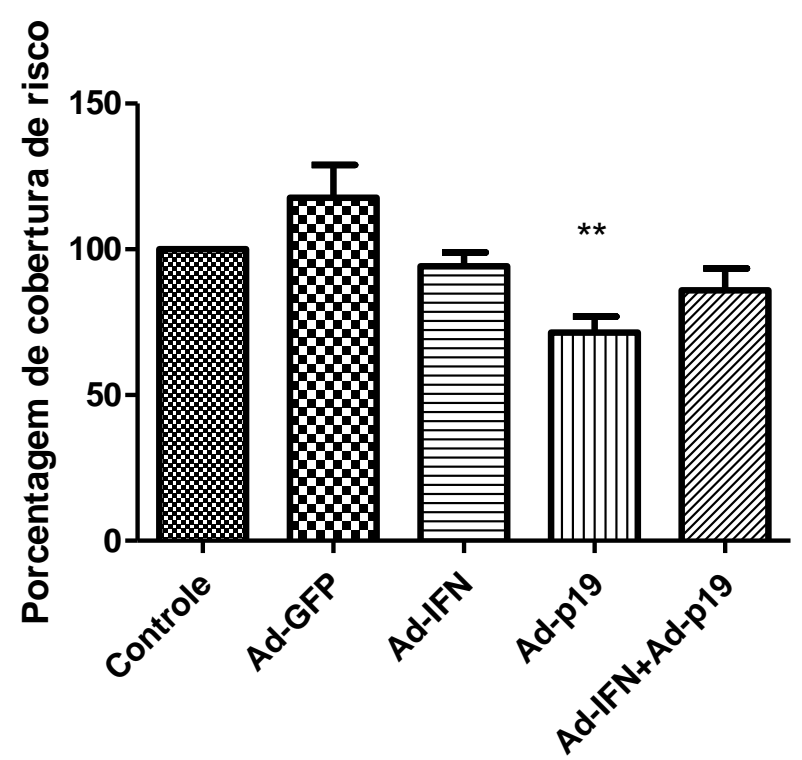

Figura 16: Ensaio de migração da linhagem tEnd transduzida pelos vetores adenovirais. (A) As imagens mostram as células da linhagem tEnd tratadas pelos vetores adenovirais migrando, as fotos foram feitas com 0 e 24 horas após transdução com MOI de 200 e adição do composto anti proliferativo Mitomicina C a 0,02mg/mL. Objetiva de 10x. (B) A quantificação da área foi realizada pelo programa Zeiss LSM Image Browser. O calculo da porcentagem de cobertura de risco e o calculo da normalização está descrito no material e métodos. Os dados representam à média e o desvio padrão de três experimentos independentes. ${ }^{* *} \mathrm{p}<0,01$; ANOVA seguido do pós-teste multi-comparativo Tukey. 


\subsubsection{Ensaio de tubologênese}

Para avaliarmos a influência do tratamento na formação de novos tubos (Tubologênese), as células da tEnd foram transduzidas pelos vetores com MOI de 200 por 6 horas e semeadas na camada de Matrigel (BD Biosciences). Foram tiradas fotos das áreas de formação de tubos após 48 horas da semeadura das células.

As imagens e a quantificação dos tubos abaixo mostram que as células da linhagem tEnd transduzidas com os vetores Ad-p19 e a co-transdução Ad-IFN+Ad-p19, tiveram menor formação de tubos no matrigel, figura 17. Foi usado dois parâmetros para estabelecer um tubo endotelial, primeiro o tubos deveria ser formado pro mais de 2 células e ter uma área maior que duas células. 
A Ad-GFP

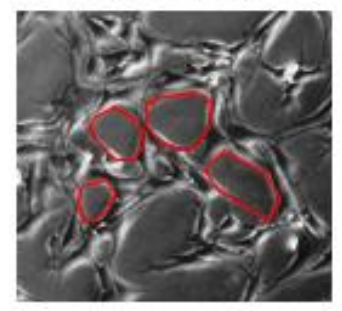

Ad-IFN Ad-p19 Ad-IFN+Ad-p19
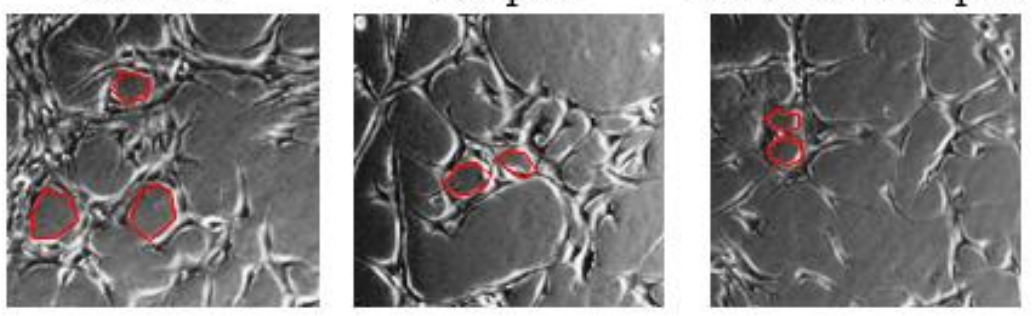

B

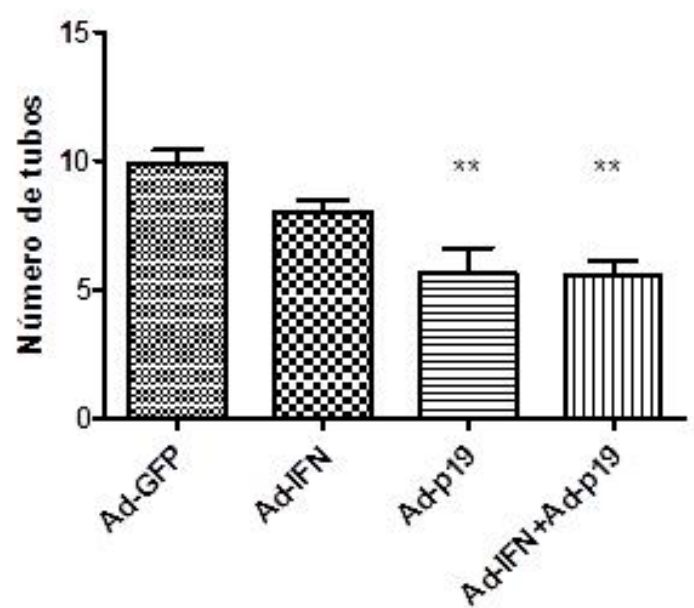

Figura 17: Ensaio de tubologênese no matrigel da linhagem endotelial tEnd transduzida pelos vetores adevirais. (A) As imagens mostram os tubos da linhagem endotelial tEnd trasnduzidas com MOI de 200 formados no matrigel após 48 horas de cultivo na placa com matrigel. Objetiva de 10x. (B) O gráfico mostra as quantidades de tubos formadas pela linhagem tEnd transduzida com os vetores adenovirais. Os dados representam à média e o desvio padrão de três experimentos independentes. **p<0,01, ANOVA seguido do pós-teste multi-comparativo Tukey.

\subsubsection{Ensaio de proliferação}

No segundo ensaio funcional, avaliamos a influencia do tratamento com nossos vetores adenovirais na proliferação das células da linhagem tEnd após a transdução utilizando o MOI de 200. Essa técnica é usada para avaliar a indução ou inibição da proliferação em células angiogênicas como a célula endotelial (Eccles et al., 2009). O ensaio foi realizado com 24 horas, diferentes de outros testes como o teste de viabilidade e morte celular, pois as células tratadas após 48 apresentam elevada 
porcentagem de morte como será demonstrado em ensaios posteriores. Esse e outros ensaios foram realizados com tempo inferior, para que o processo de morte celular não interfira nos ensaios. Os resultados não são significativos, mas sugerem que a célula endotelial transduzida pelo vetor adenoviral contribui para diminuir a taxa de proliferação e que a co-trandução tem maior efeito em inibir a proliferação, figura 18.

A

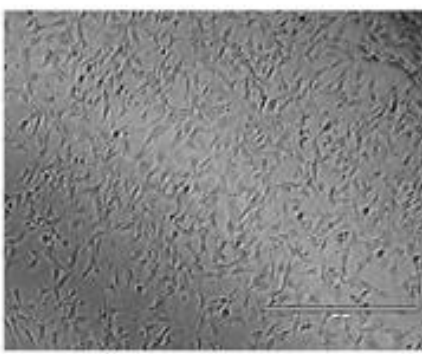

Controle

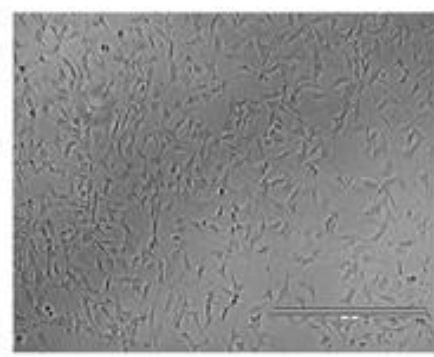

Ad-GFP

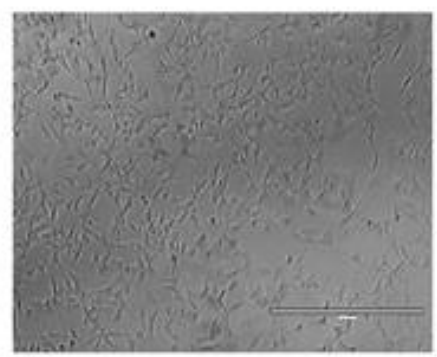

Ad-IFN

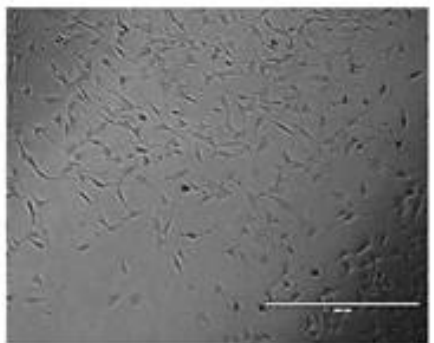

Ad-p19

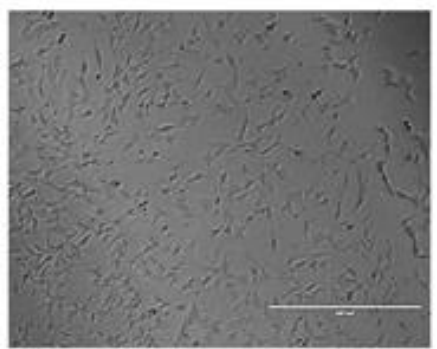

Ad-IFN+Ad-p19

B

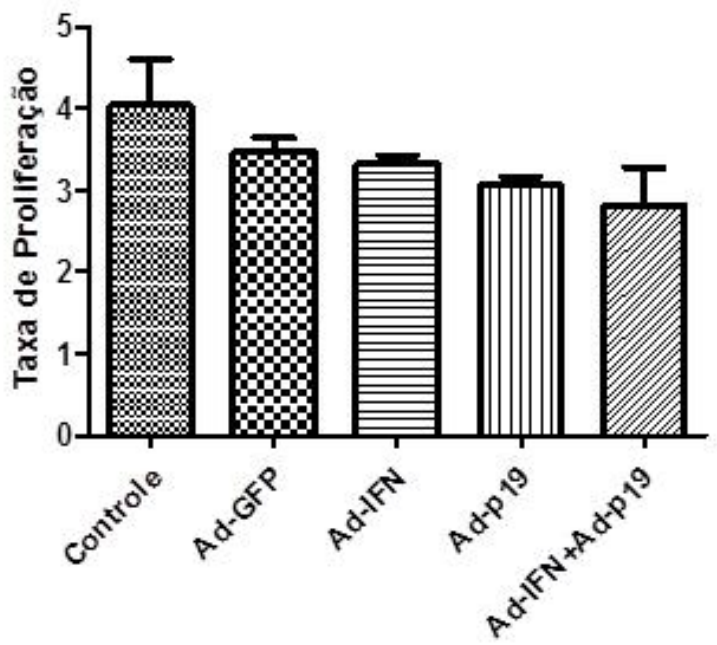

Figura 18: Ensaio de proliferação para a linhagem tEnd transduzida com os vetores adenovirais. (A) As imagens da linhagem tEnd em placas de 96 poços após 24 horas da transdução com MOI de 200. Objetiva de 10x. (B) O número de células por campo foi quantificada manualmente no programa Image $J$. O calculo da taxa de proliferação foi feito como descrito no material e métodos. Os dados representam à 
média e o desvio padrão de três experimentos independentes. ANOVA seguido do pós-teste multicomparativo Tukey.

\subsubsection{Ensaio de citotoxicidade}

O primeiro ensaio funcional teve como objetivo investigar o efeito citotóxico do tratamento com os vetores adenovirais portadores dos genes terapêuticos IFN $\beta$ e p19Arf, na linhagem de células endoteliais tEnd, 48 horas após a transdução usando MOI de 200. s resultados do ensaio de viabilidade mostram que somente a cotransdução com os vetores Ad-IFN + Ad-p19 conferiu uma queda de viabilidade significante, figura 19. Transdução com o vetor Ad-p19 sozinho mostra uma tendência de diminuir a viabilidade das células tEnd, porem não alcançou significância, enquanto os vetores Ad-GFP e Ad-IFN não tiveram influência significativa na viabilidade das células transduzidas.

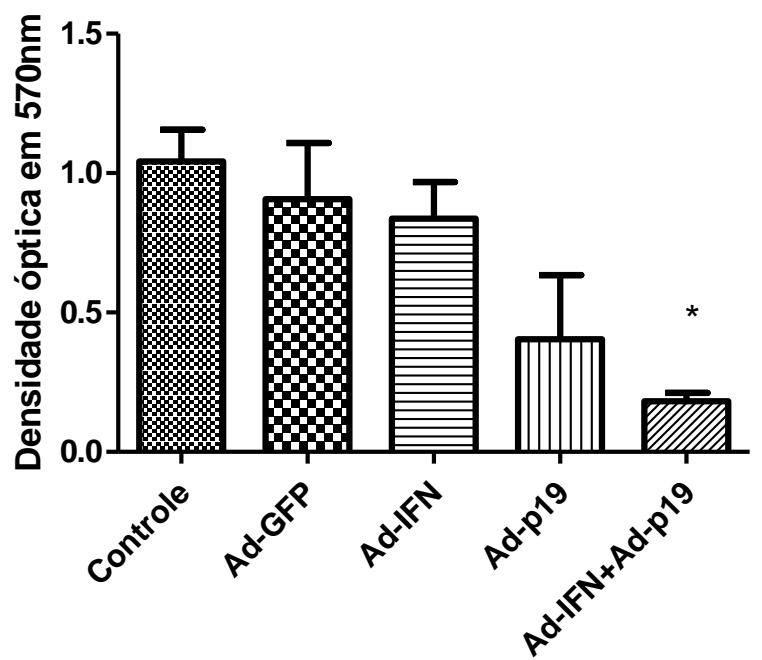

Figura 19: Ensaio de viabilidade por MTT da linhagem tEnd transduzida pelos vetores adenovirais. As células da tEnd foram transduzidas com MOI de 200, o ensaio foi analisado após 48 horas da transdução. Os dados representam à média e o desvio padrão de três experimentos independentes. ${ }^{*} \mathrm{p}<0,05$; ANOVA seguido do pós-teste multi-comparativo Tukey. 


\subsubsection{Ensaio clonogênico}

Neste ensaio as células foram semeadas em baixa quantidade após serem transduzidas, esperando-se que as células aderissem ao fundo dos poços e formassem colônias.

Como ilustrada na figura 20, as células da tEnd tratadas com a co-transdução Ad-IFN+Ad-p19, tiveram uma menor formação de colônias se comparado com os controles. A transdução com o vetor Ad-p19 sozinho mostrou uma tendência em diminuir a clonogenicidade das células tEnd, porem não alcançou significância. $O$ tratamento com os vetores Ad-GFP e Ad-IFN não tiveram influência significativa neste ensaio. 
A

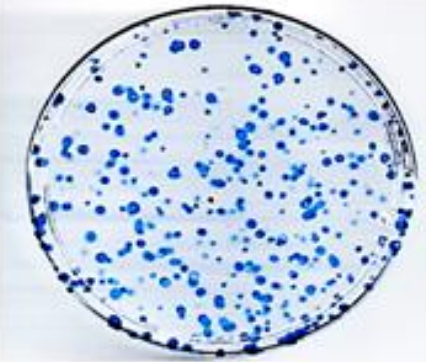

Controle

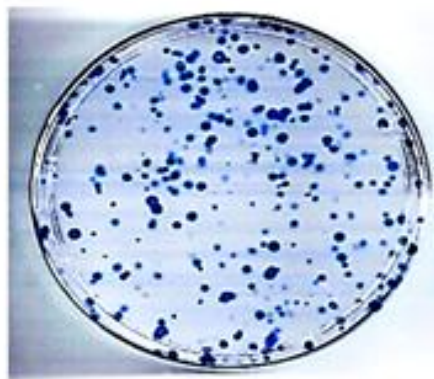

Ad-GFP

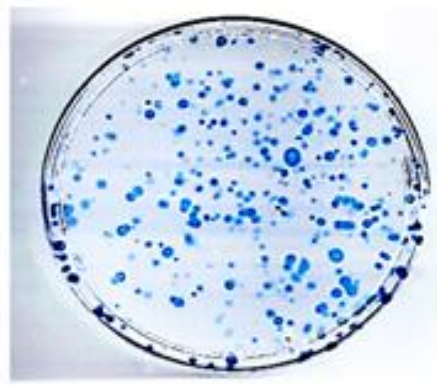

Ad-IFN

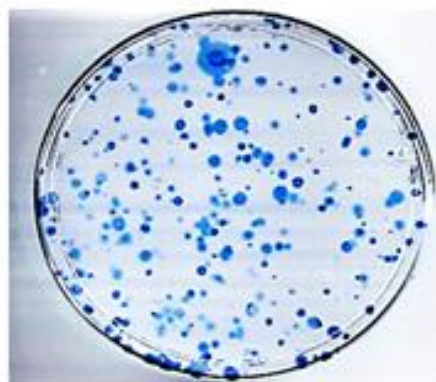

Ad-p19

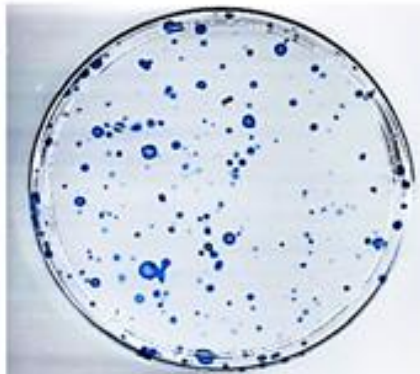

Ad-IFN+Ad-p19

B

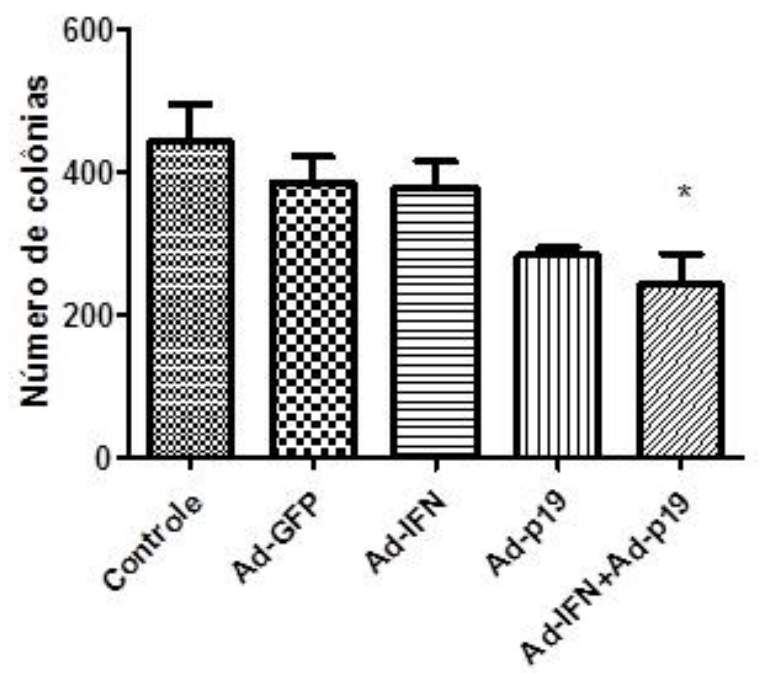

Figura 20: Ensaio clonogênico da linhagem tEnd transduzida com os vetores adenovirais. (A) As imagens mostram as colônias nas placas de $10 \mathrm{~cm}$ da linhagem tEnd transduzidas com MOI de 200 por 6 horas e 1000 destas células foram semeadas e cultivadas por 10 dias e fixadas. (B) Os clones foram quantificados manualmente. Os dados representam a média e o desvio padrão de três experimentos independentes. ${ }^{*} \mathrm{p}<0,05$; ANOVA seguido do pós-teste multi-comparativo Tukey. 


\subsubsection{Ensaio de ciclo celular da linhagem tEnd}

Para avaliarmos os efeitos no ciclo celular na linhagem endotelial tEnd tratada pelos vetores adenovirais, 48 horas após serem transduzidas, as células foram coletadas, fixadas e marcadas com iodeto de propídio (P.I.) e analisadas por citometria de fluxo. Os resultados mostram que o tratamento com os vetores Ad-p19 e Ad-IFN+Ad-p19 apresentam ciclo celular diferenciado se comparado com os controles, com maior quantidade de células hipodiploides e menor quantidade de células nas fases S e G2, figura 21. 
A

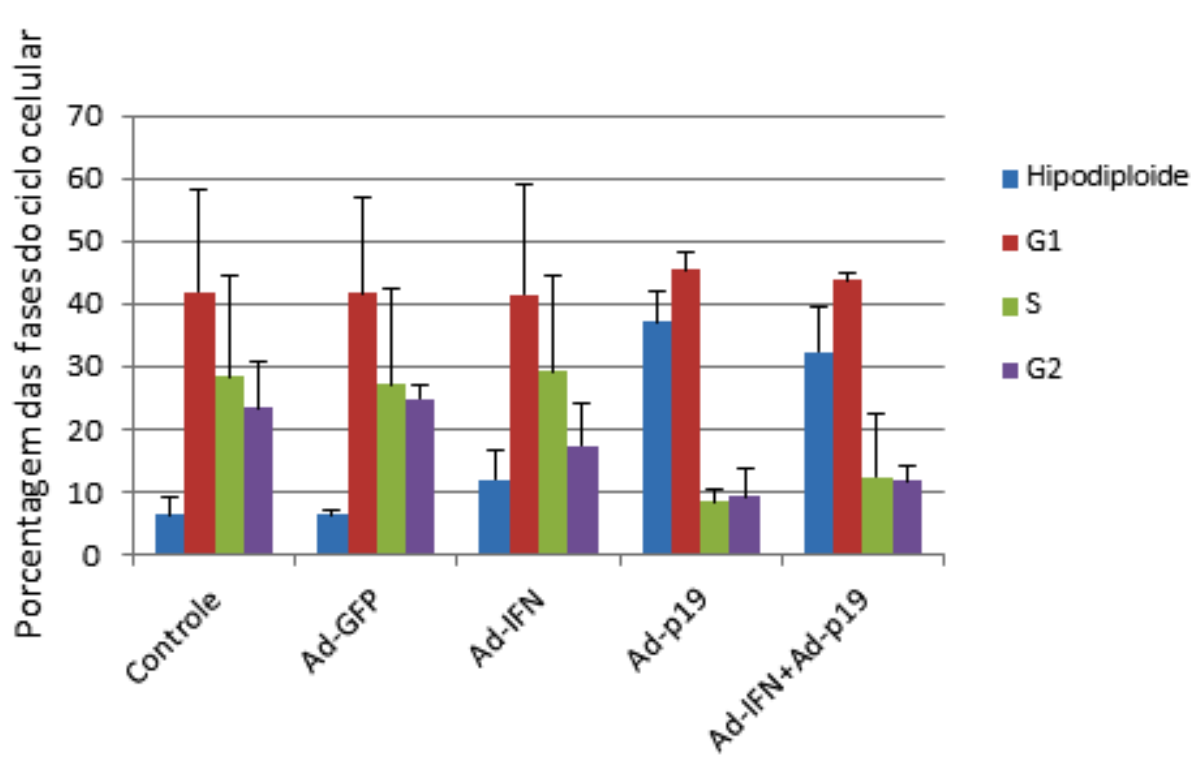

B

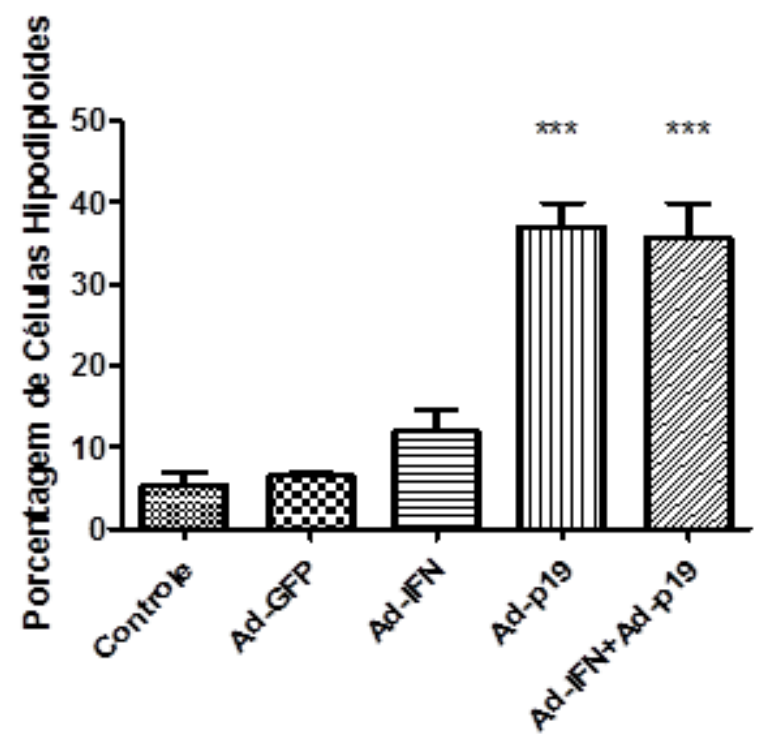

Figura 21: Ensaio de ciclo celular por citometria para a linhagem tEnd tratada com os vetores adenovirais. As células da tEnd foram transduzidas com MOI de 200 e cultivadas por 48 horas, fixadas e marcadas com P.I. A analise do ciclo celular foi realizada por citometria de fluxo (Attune- Life Technologies). (A) Gráfico com o ciclo celular da linhagem tEnd transduzida com os vetores. (B) Gráfico com a porcentagem de células hipodiploides no ensaio de ciclo celular da linhagem tEnd transduzida com os vetores. Os dados representam à média e o desvio padrão de três experimentos independentes. ***p<0,001, ANOVA seguido do pós-teste multi-comparativo Tukey. 
4.3.8. Ensaio de marcação das células por Anexina-V

O ensaio de marcação de células por Anexina-V, consiste em quantificar células onde células em estado de morte exibem a fosfatidilserina na superfície celular (Bouter et al., 2015).

O gráfico da figura 22 mostra a porcentagem de células marcadas para AnexinaV + P.I, após 48 horas de transdução com os vetores usando MOI de 200. Os resultados mostraram que mostram que vetor Ad-p19 e a co-transdução Ad-IFN+Ad-p19 aumentaram consideravelmente a porcentagem de células mortas. Nesse ensaio, foi utilizado o vetor Ad-LacZ como vetor controle, para evitarmos a sobreposição de sinais com que o vetor Ad-GFP causaria com a Anexina-V-Alexa 488 que apresentam fluorocromos com o mesmo espectro de emissão.

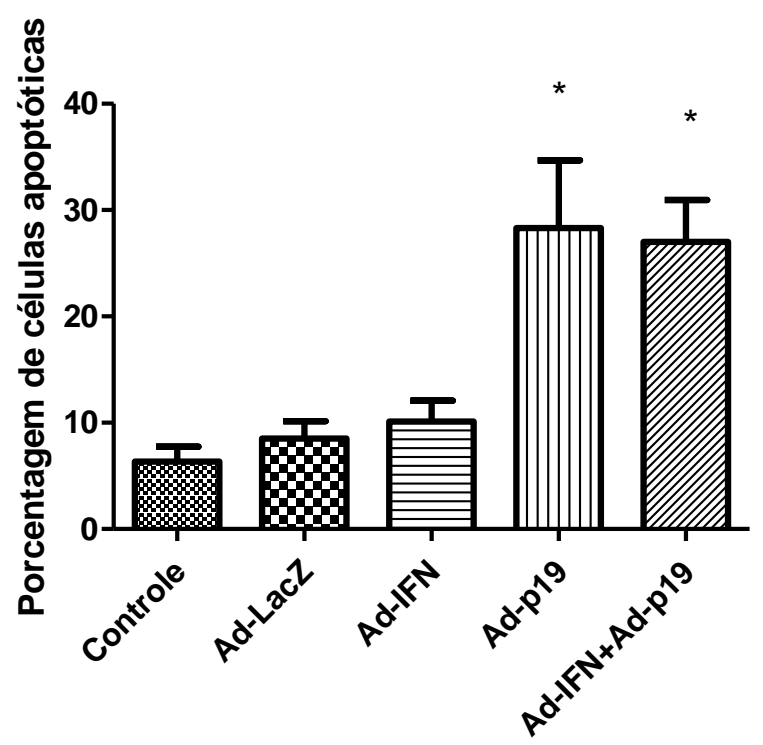

Figura 22: Citometria de fluxo para detecção de células apoptóticas da linhagem tEnd transduzidas pelos vetores adenovirais e marcadas com AnexinaV e P.I. As células da tEnd foram transduzidas com MOI de 200 e após 48 horas foram coletadas, marcadas com P.I e Anexina e analisadas por citometria de fluxo para a porcentagem de células apoptóticas.. Os dados representam a média e o desvio padrão de três experimentos independentes. ${ }^{*} \mathrm{p}<0,05$, ANOVA seguido do pós-teste multicomparativo Tukey. 


\subsection{EXPRESSÃO GÊNICA DAS CÉLULAS tEnd TRANSDUZIDAS PELOS VETORES ADENOVIRAIS}

Neste ensaio de expressão gênica relativa pela técnica de RTq-PCR avaliamos as células da linhagem tEnd 24 horas após serem trasnduzidas com os vetores usando MOI de 200. O ensaio de expressão gênica foi dividido em dois grupos: expressão de genes relacionados à via de p53 e o grupo com os genes pró-angiogênicos. O gene referência foi a $\beta$-actina. $\mathrm{O}$ método de análise foi $2^{-\Delta \Delta \mathrm{Ct}}$, os dados estão apresentados como fold change, comparados com as células transduzidas pelo vetor Ad-GFP. As sequências dos oligonucleotídeos estão expostas na tabela 02.

\subsubsection{Expressão de genes da via de p53}

Os primeiros ensaios de expressão genica foram realizados para genes relacionados a vida de p53 e relacionados a apoptose após tratamento com os nossos vetores.

A co-transdução Ad-IFN+Ad-p19 aumentou a expressão de p53, enquanto a transdução pelo vetor Ad-p19 não foi significativa, mas mostrou uma tendência em aumentar a p53. A MDM2 teve sua expressão aumentada nas células tEnd transduzidas com Ad-p19 e com a co-transdução Ad-IFN+Ad-p19. A ativação de p21 foi significativa somente após tratamento da tEnd com Ad-p19, enquanto a expressão de 
Puma foi elevada quando Ad-p19 e a combinação Ad-IFN+Ad-p19 foi aplicada, figura

23.

Os resultados mostram que a transferência gênica principalmente com p19Arf induz aumento da expressão de genes relacionados a via de morte de p53, como o próprio p53, MDM2, p21 e Puma.
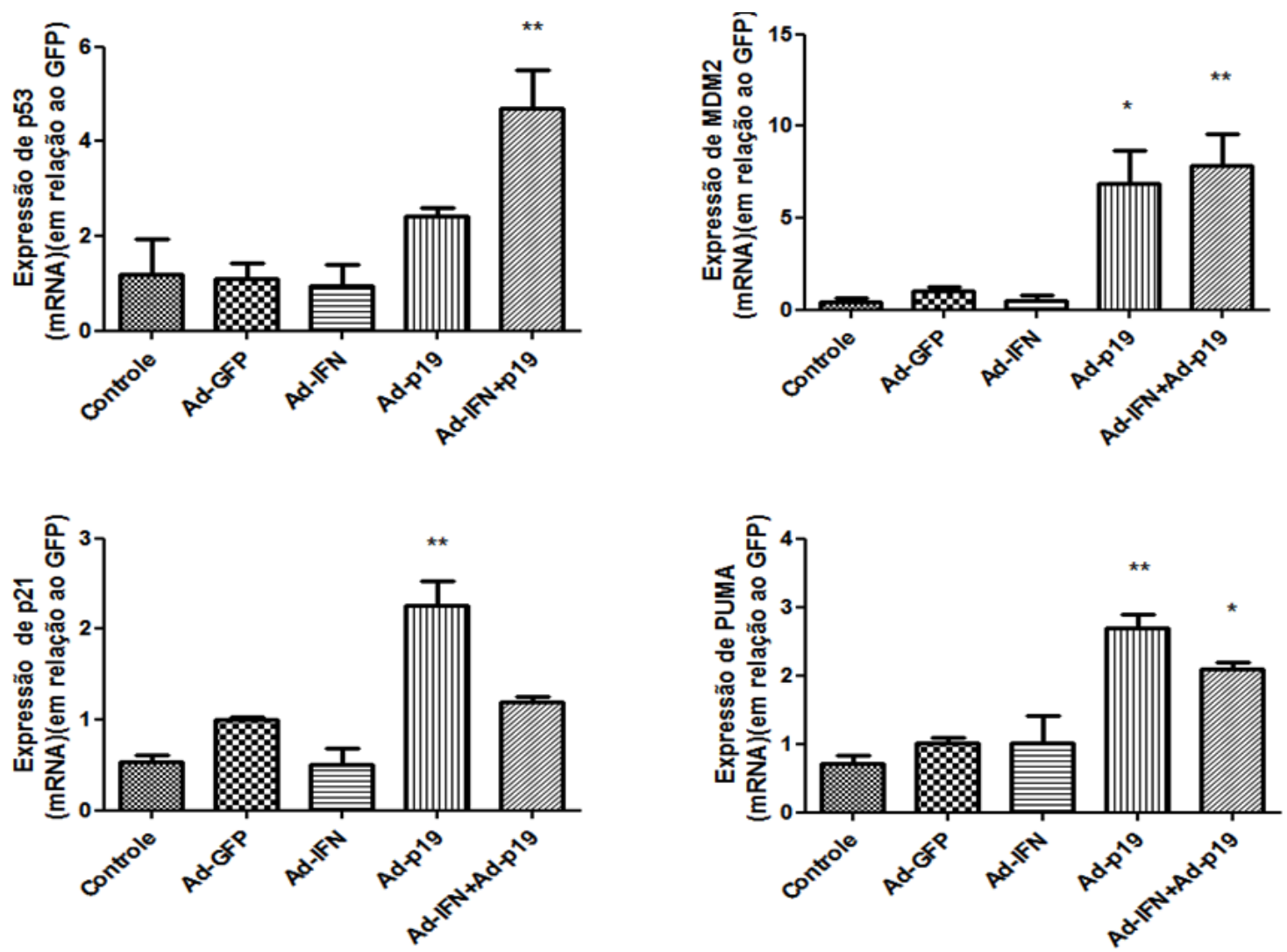

Figura 23: Expressão gênica dos genes da via de p53 na linhagem tEnd transduzida com os vetores adenovirais. As células tEnd foram transduzidas com MOI de 200 e incubadas por 24 horas antes de realizarmos o ensaio de RT-qPCR. Foram feitos ensaios para os genes p53, MDM2, p21 e PUMA. Os dados representam à média e o desvio padrão de três experimentos independentes. ${ }^{*} \mathrm{p}<0,05 ; * * \mathrm{p}<0,01, \mathrm{o}$ teste estatístico realizado foi o ANOVA seguido do pós-teste multi-comparativo Tukey. 


\subsubsection{Expressão de fatores pró-angiogênicos}

A transferência gênica de p19Arf e IFN $\beta$ coopera para induzir expressão de VEGF-A, enquanto o Ad-p19 sozinho mostra somente tendência de aumentar a expressão de VEGF-A. Mostramos a analise da expressão de ANG-2, revelando que a transferência gênica com o vetor Ad-p19 e a co-transdução Ad-IFN+Ad-p19 aumentaram a expressão de ANG-2 nas células de tEnd. A VE-caderina não apresentou alteração na expressão significativa nas células tEnd após transdução com os vetores adenovirais, mas os dados indicam que os vetores Ad-IFN, Ad-p19 e Ad-IFN+Ad-p19 aumentaram a expressão de VE-caderina. Como no ensaio da VE-caderina o fator bFGF não apresentou diferenças significativas, mas os dados mostram que a transdução pelos vetores de Ad-IFN, Ad-p19 e a co-transdução Ad-IFN+Ad-p19 induzem aumento na expressão de bFGF. O ensaio de expressão para HIF-1a não apresentou diferenças significativas, mas a transdução com o vetor Ad-p19 e a co-trandução indicam que esses tratamentos induzem aumento de HIF-1 $\alpha$, figura 24. 

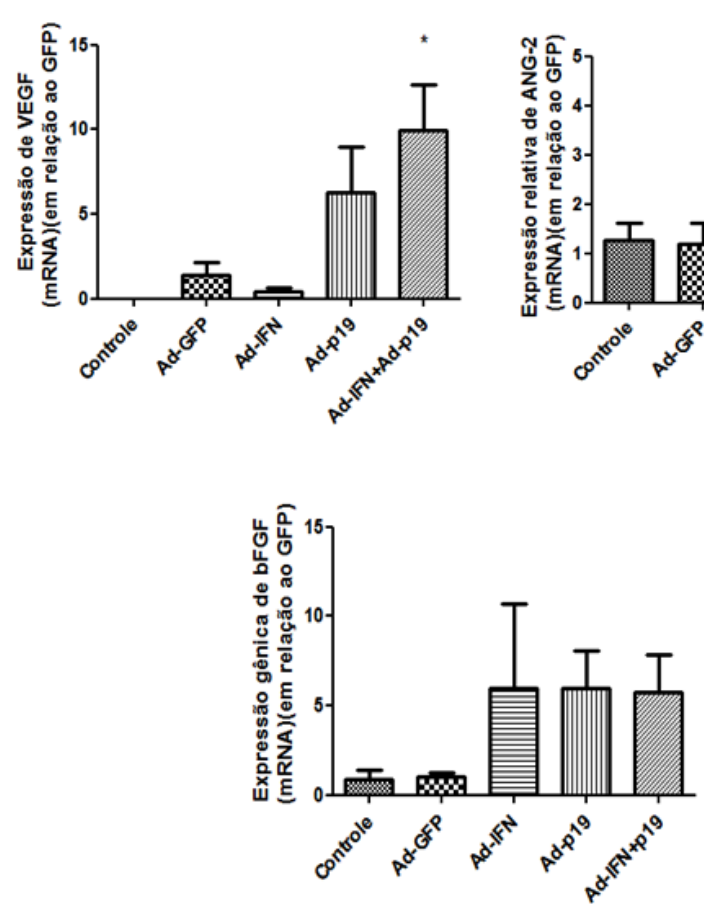
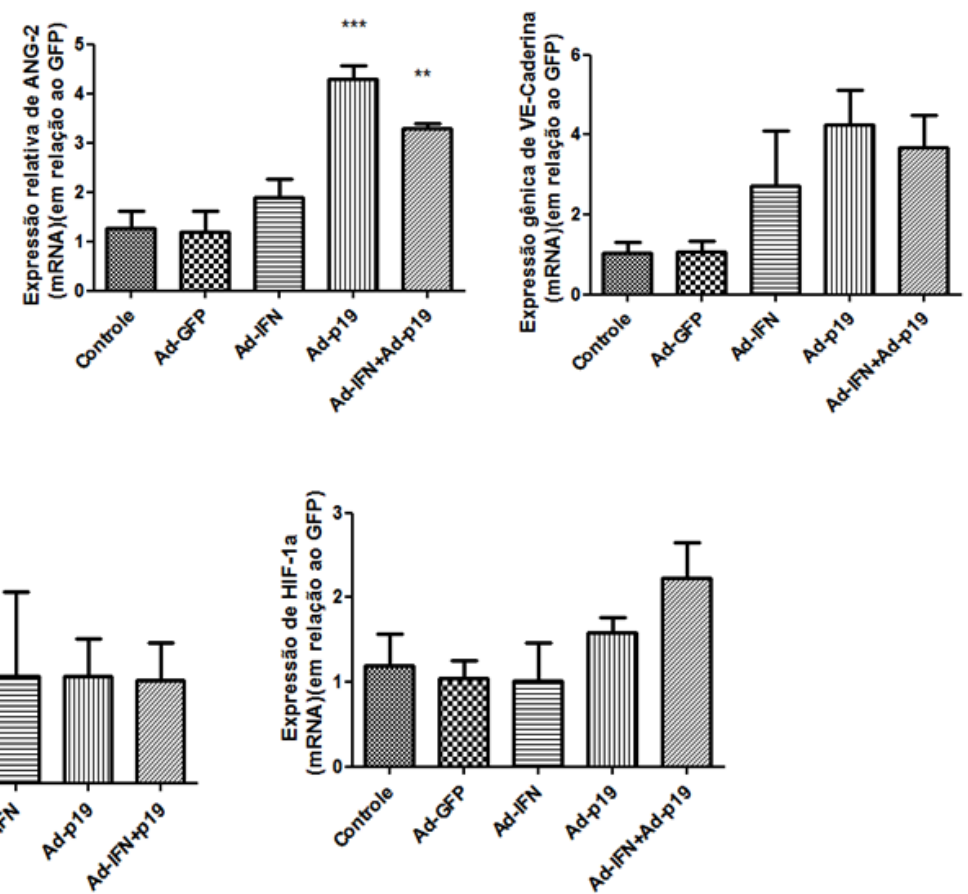

Figura 24: Expressão gênica de genes pró-angiogênicos na linhagem tEnd transduzida com os vetores adenovirais. As células tEnd foram transduzidas com MOI de 200 e incubadas por 24 horas antes de realizarmos o ensaio de RT-qPCR. Foram feitos ensaios para os genes VEGF, ANG-2, VE-Caderina, bFGF e HIF-1 $\alpha$. Os dados representam à média e o desvio padrão de três experimentos independentes. $* \mathrm{p}<0,05 ; * * \mathrm{p}<0,01 ; * * * \mathrm{p}<0,001$, o teste estatístico realizado foi o ANOVA seguido do pós-teste multicomparativo Tukey.

\subsection{ENSAIOS DE EFEITO PARÁCRINO}

\subsubsection{Seleção da linhagem tEndTO}

O ensaio de co-cultura entre a linhagem tEnd e B16 só foi possível depois que conseguimos obter um clone da linhagem endotelial marcada com a proteína vermelha fluorescente tomato sendo expressa constitutivamente. Com essa linhagem de fácil identificação, foi possível quantificar e separar as duas linhagens do mesmo poço.

Usamos o vetor lentiviral (vetor que integra o transgêne no DNA da célula) Lego-iT2 para transduzir as células da linhagem tEnd e obter clones fluorescentes. Obtivemos clones tEndTO onde $100 \%$ das células possuem fluorescência vermelha. As imagens da figura 25 mostram mais claramente pela colocalização da marcação do 
núcleo pelo DAPI e do citoplasma marcado pela proteína tomato que as células estão todas marcadas, a figura 26 mostra em um aumento menor todas as células marcadas para tomato e DAPI. A figura 27 mostra um ensaio de co-cultura com as linhagens B16 previamente transduzidas pelo vetor Ad-GFP e a células da tEndTO, as imagens dessa figura mostram que esse ensaio de co-cultura é de fácil execução e de simples diferenciação das células B16 e tEndTO. Neste modelo proposto, as células da B16 foram previamente transduzidas e lavadas para remoção dos vetores não incorporados, o ambiente do ensaio estava limpo dos adenovírus e as células tEndTO não tiveram contato com os vetores. Desse modo fizemos o ensaio de efeito parácrino sem a presença dos vetores, apenas com as células da B16 transduzidas e as células linhagem tEndTO.
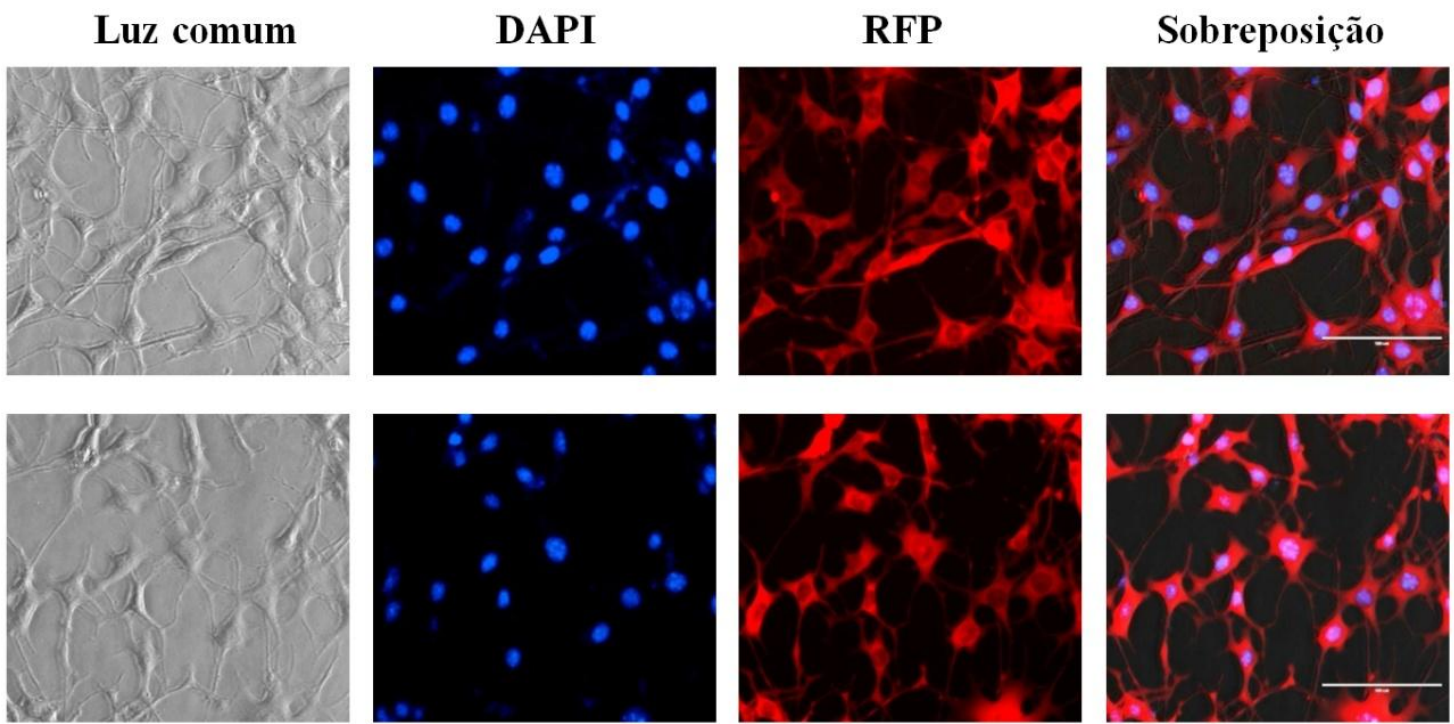

Figura 25: Linhagem tEndTO selecionada marcada com a proteína tomato. Imagens das células da linhagem tEndTO (Linha de cima e de baixo) captadas pelo microscópio EVOS. Os núcleos foram corados com Hoescht e visualizados com o filtro para DAPI e a proteína fluorescente Tomato foi observada através do filtro para RFP (red fluorescente protein). Objetiva de 40x. 


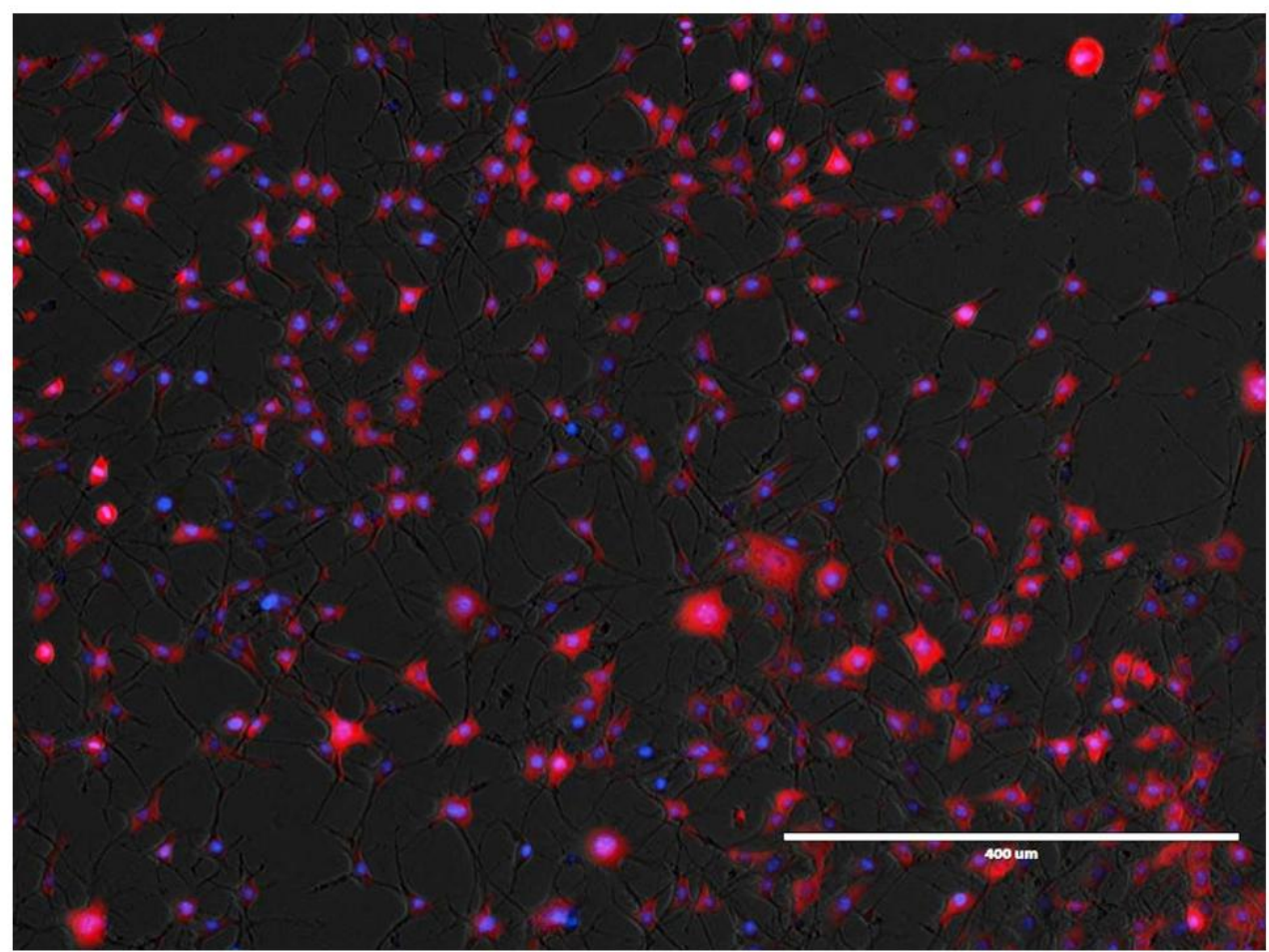

Figura 26: Linhagem tEndTO, $100 \%$ das células marcadas com a proteína tomato. Imagem das células da linhagem tEnd TO captadas pelo microscópio EVOS. Sobreposição entre as lentes; luz comum, DAPI e RFP. Objetiva de 10x.

Luz comum

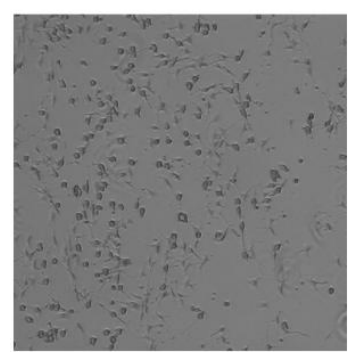

RFP

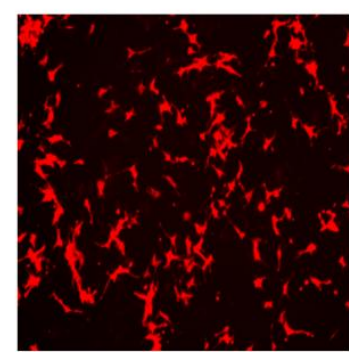

488

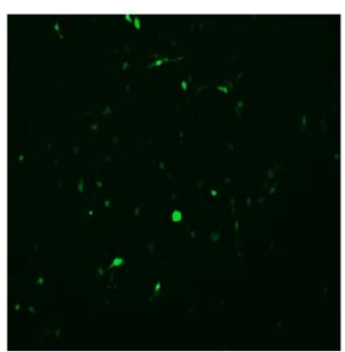

\section{Sobreposição}

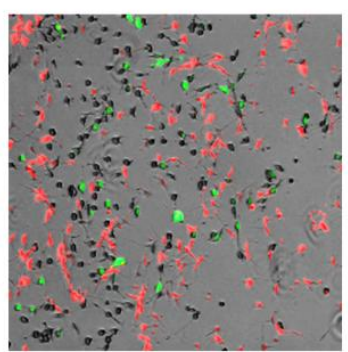

Figura 27: Ensaio prévio da co-cultura entre as linhagens B16 transduzida com Ad-GFP e tEndTO. Imagens da co-cultura entre as linhagens B16 e tEnd TO, onde a linhagem B16 foi previamente transduzida com o vetor Ad-GFP, foram tiradas fotos pelo microscópio EVOS em uma placa de 6 poços, as 4 imagens foram feitas no mesmo campo, a primeira imagem da co-cultura tirada com a luz comum, a segunda usando apenas o filtro RFP, a segunda imagem com o filtro 488 e a ultima imagem a sobreposição entre as 3 imagens. Objetiva de 10x. 


\subsubsection{Ensaio de co-cultura}

A técnica de co-cultura de células in vitro, consiste em cultivar células de diferentes tecidos misturadas numa única placa de cultivo. $\mathrm{O}$ ensaio de co-cultura tem como objetivo realizar um biomimetismo do ambiente natural in vitro, com condições de interação que representam o mais próximo à condição in vivo. Neste ensaio podemos estudar as interações entre células de tecidos diferentes frente a um tratamento (Goers et al., 2014).

Para avaliarmos o efeito paracrino nas células endoteliais próximas as células tumorais de melanoma tratadas com vetores adenovirais portadores dos trangênes IFN $\beta$ e p19Arf, foi realizado o ensaio de co-cultura onde adicionamos a linhagem tEndTO com a linhagem B16 previamente transduzida com os vetores adenovirais Ad-GFP, AdIFN, Ad-p19 e a cotransdução Ad-IFN+Ad-p19 em placas de 6 poços, foram semeadas o dobro das células de B16, pois as células da tEndTO tem taxa de proliferação duas vezes maior que a linhagem tumoral.

As duas linhagens B16 e tEndTO, utilizadas no ensaio de co-cultura, não induziam qualquer tipo de inibição ou indução na célula oposta, nas condições normais. Essa observação inicial foi conclusiva, para realizarmos o ensaio de co-cultura.

Tiramos fotos nos tempos 24, 48 e 72 horas após as células serem semeadas. Este ensaio mostrou que as células da linhagem tumoral B16 foram inibidas pelo tratamento com os vetores, Ad-IFN, Ad-p19 e a co-transdução e que as células da linhagem tEndTO não transduzidas, também foram inibidas nos poços onde havia células da linhagem B16 transduzidas pelos vetores Ad-IFN e o Ad-IFN+Ad-p19, figuras 28 e 29. Levando em consideração que as duas linhagens usadas neste ensaio são aderentes e que se soltam do fundo das placas quando estão em fase avançada de 
morte, nós consideramos as células aderidas como viáveis e passiveis de contagem para quantificação da população de cada linhagem. 


\section{B16 + tEndTO}

Luz branca + RFP
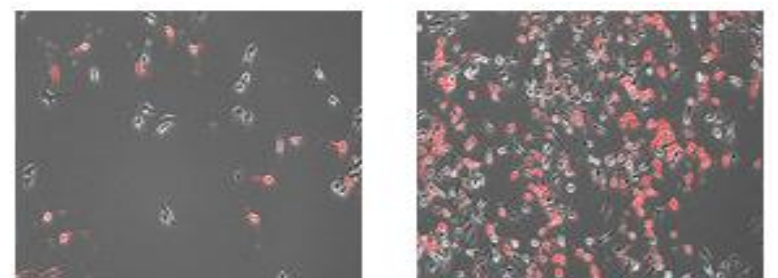

\section{Controle}
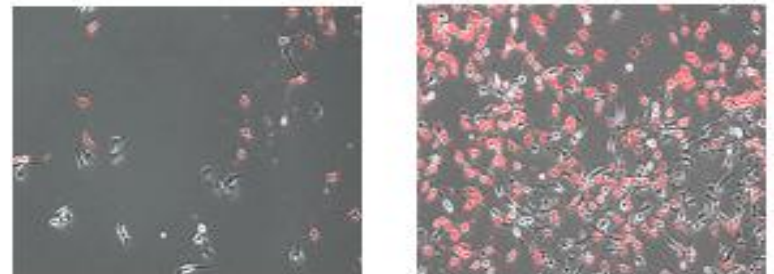

\section{B16-GFP}
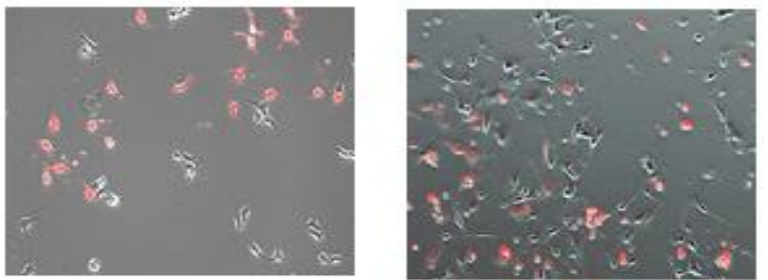

\section{B16-IFN}
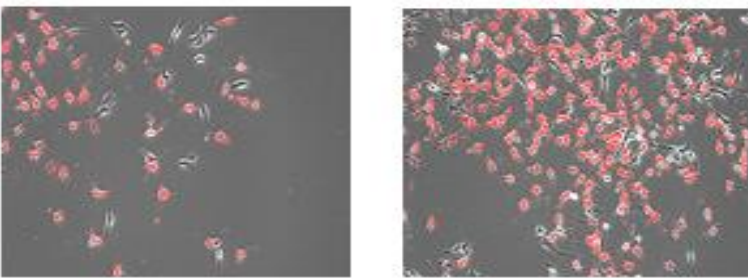

\section{B16-p19}
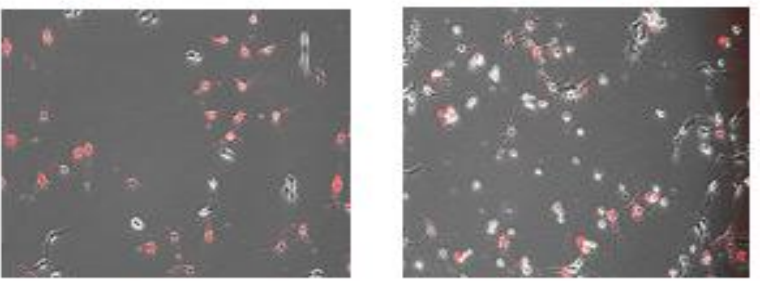

\section{B16-IFN+p19}

24 horas

72 horas

Figura 28: Ensaio de co-cultura entre a linhagem B16 previamente transduzida pelos vetores adenovirais e a linhagem tEndTO. A linhagem B16 foi transduzida com MOI de 300 por 6 horas, lavada em PBS 3x e semeada juntamente com a linhagem tEnd To identificada pela marcação pela coloração vermelha e a linhagem B16 identificada pela cor cinza escuro. A primeira coluna mostra os campos no tempo 24 horas e a segunda coluna mostra os campos no tempo 72 horas após as células serem semeadas. Objetiva de 10x. 
A

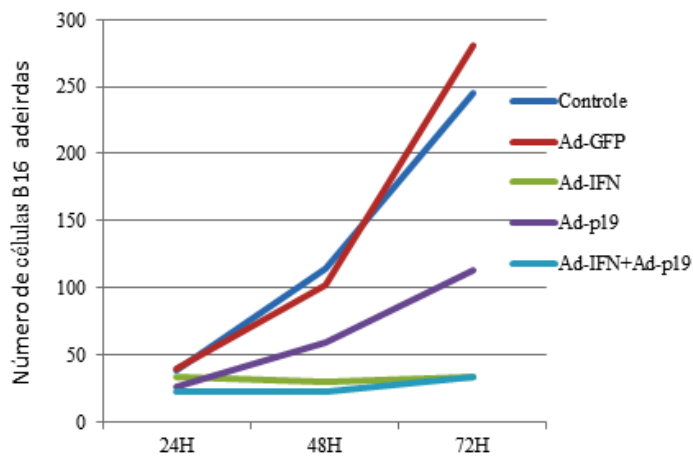

$\mathrm{C}$

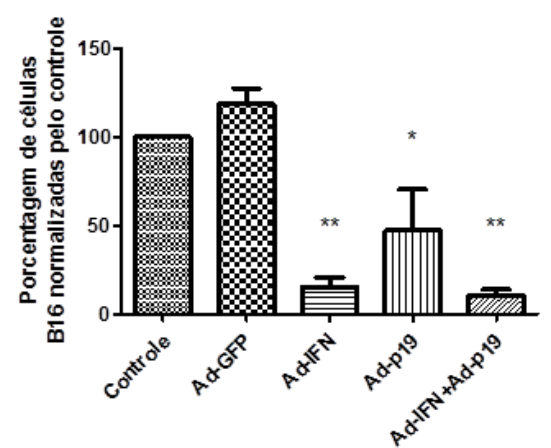

B

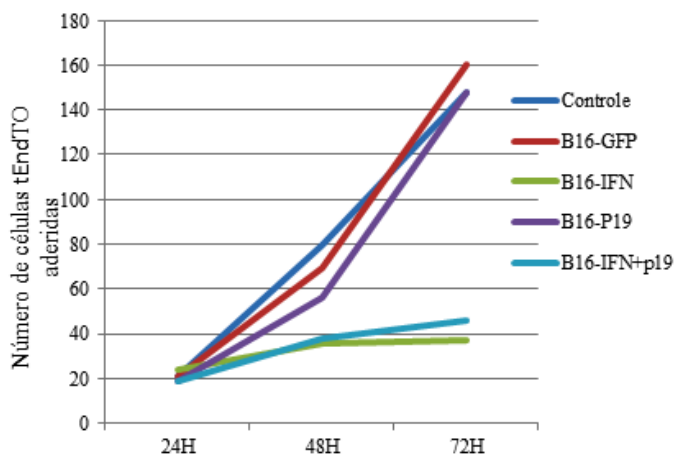

$\mathrm{D}$

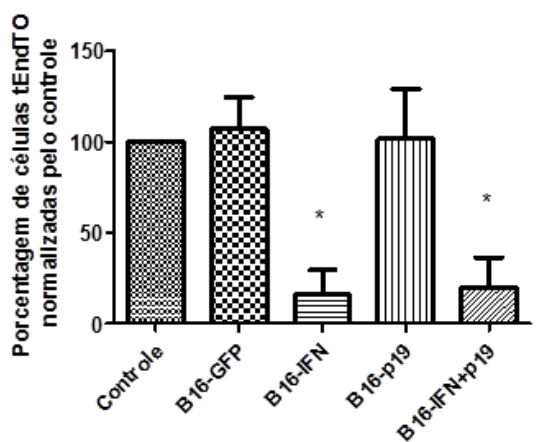

Figura 29: Contagem das células da linhagem B16 e tEndTO do ensaio de co-cultura. Os poços da co-cultura foram semeados pela linhagem tEndTO e a linhagem B16 previamente transduzida pelos os vetores com MOI de 300 por 6 horas com os vetores adenovirais, foram tiradas fotos desses poços nos tempos 24, 48 e 72 horas após as duas linhagem serem semeadas. (A) Gráfico de contagem das células da linhagem B16 previamente transduzida pelos vetores. (B) Gráfico da contagem das células da linhagem tEndTO cultivada juntamente com as células da linhagem B16 que foram previamente transduzidas. (C) Gráfico com a taxa de células da linhagem B16, 72 horas após serem semeadas nos poços para o ensaio de co-cultura. (D) Gráfico com a taxa de células da linhagem tEndTO, 72 horas após ser semeada no ensaio de co-cultura. As células foram fotografadas pelo microscópio de fluorescência invertido EVOS e as quantidades de células foram quantificadas pelo programa Image J. O calculo da taxa de células normalizado pelo controle encontra-se no material e métodos. Os dados representam à média e o desvio padrão de três experimentos independentes. ${ }^{*}<<0,05$; $*{ }^{*}<<0,01$, ANOVA seguido do pós-teste multicomparativo Tukey. 
4.5.3. Ensaio de citotoxicidade da linhagem tEnd tratada com o meio condicionado proveniente da linhagem B16 tratada com os vetores adenovirais portadores de IFN e $\underline{\mathrm{p} 19}$

A partir desse ensaio, iniciamos o uso do meio condicionado, produzido pela linhagem B16 transduzida com os vetores; Ad-GFP, Ad-IFN, Ad-p19 e Ad-IFN+Adp19; foram assim produzidos os meios condicionados (mc): mc-B16, mc-B16-GFP, mcB16-IFN, mc-B16-p19 e mc-B16-IFN+p19 respectivamente. O ensaio de viabilidade celular (MTT) foi o primeiro ensaio a usar o meio condicionado e mostrou que os meios condicionados da linhagem B16 transduzida com Ad-IFN e Ad-IFN+Ad-p19 diminuíram a viabilidade das células da tEnd, figura 30.

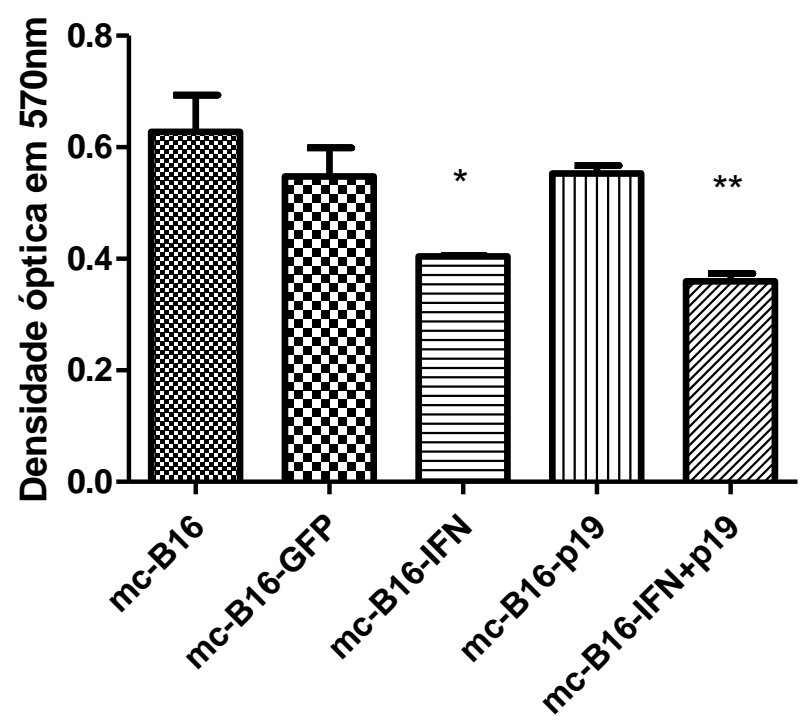

Figura 30: Ensaio de MTT para a linhagem tEnd tratada com o meio condicionado da linhagem B16 transduzida com os vetores adenovirais. As células da tEnd foram tratadas com os meios condicionados provenientes das células da B16 transduzidas com MOI de 300 por 6 horas, lavadas e cultivas por 48 horas, o meio foi retirado e limpo. Os dados representam à média e o desvio padrão de três experimentos independentes. $* * \mathrm{p}<0,01$ e $* \mathrm{p}<0,05$, ANOVA seguido do pós-teste multi-comparativo Tukey. 
4.5.4. Ensaio clonogênico da linhagem tEnd tratada com o meio condicionado proveniente das células da B16 transduzida com os vetores

O ensaio clonogênico foi utilizado para avaliar a aderência, sobrevivência e a proliferação na formação de colônias da linhagem endotelial tEnd. Neste ensaio, as células foram plaqueadas juntamente com o meio condicionado proveniente da linhagem B16 transduzida com os vetores. A quantificação de colônias formadas nas placas indicou que as células da linhagem tEnd que foram tratadas com meio condicionado da B16 transduzida com Ad-IFN e o Ad-INF+Ad-p19 tiveram uma redução significativa na formação de colônias, figuras 31 . 
A

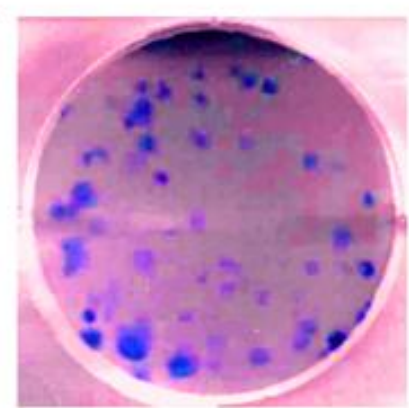

mc-B16-Controle

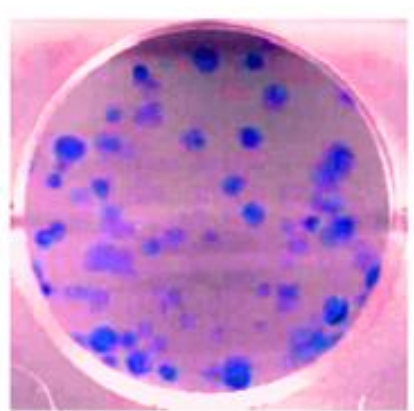

mc-B16-GFP

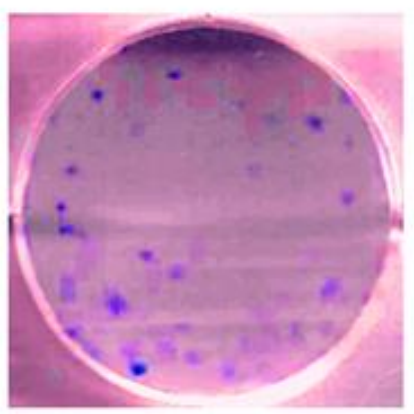

mc-B16-IFN

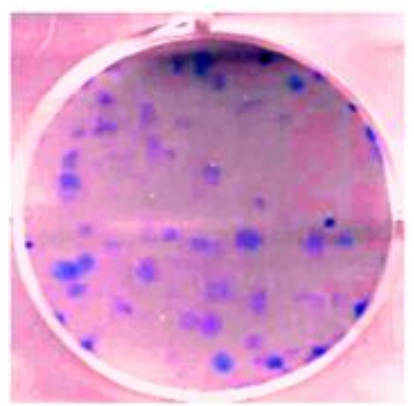

mc-B16-p19

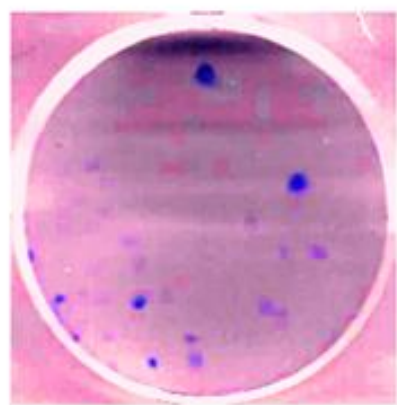

me-B16-IFN+p19

B

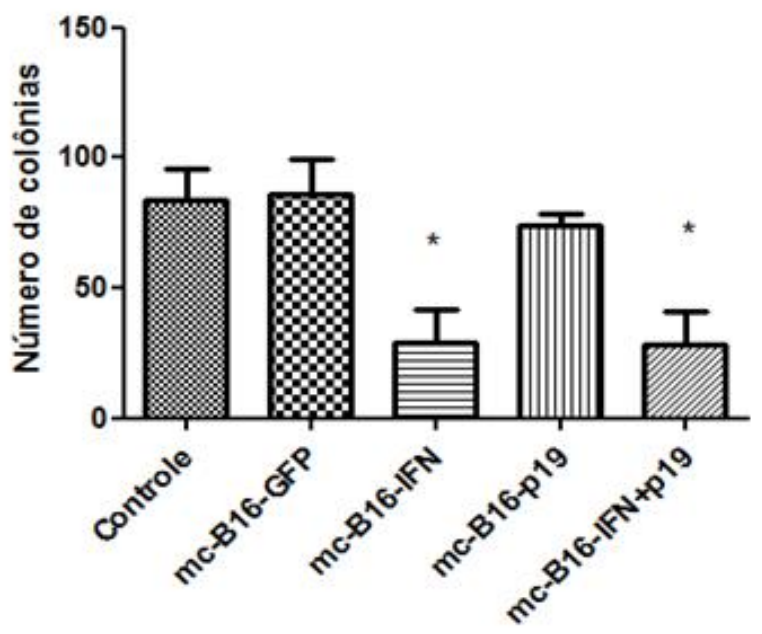

Figura 31: Ensaio clonogênico da linhagem tEnd tratada com o meio condicionado proveniente da linhagem B16 transduzida com os vetores adenovirais. Foram usadas 300 células da linhagem tEnd, para serem cultivadas com meio condicionado em placas de 6 poços por 10 dias. Após o período de cultivo, as colônias foram fixadas e coradas com Tripan Blue. A contagem foi realizada manualmente. (A) Representa as fotos tiradas dos poços do ensaio clonogeênico. (B) Gráfico com o número de colônias do ensaio clonogênico. . Os dados representam amédia e o desvio padrão de três experimentos independentes. ${ }^{*} \mathrm{p}<0,05$, ANOVA seguido do pós-teste multi-comparativo Tukey. 
4.5.5. Ensaio de ciclo celular da linhagem tEnd tratada com meio condicionado.

No ensaio de co-cultura, observamos que a linhagem B16 transduzida com vetores que possuem o transgêne IFN, aparentemente inibiam as células endoteliais que estavam cultivadas no mesmo poço.

Neste ensaio, utilizamos o meio condicionado para tratar as células tEnd com esse meio por 48 horas, coletamos as células, marcamos com P.I e analisamos o ciclo celular das células por citometria de fluxo. Os resultados mostram que os meios condicionados provenientes da linhagem B16 transduzida com os vetores Ad-IFN e da co-transdução Ad-IFN+Ad-p19 tiveram maior quantidade de células hipodiploides e menor quantidade de células na fase G1, figura 32. 

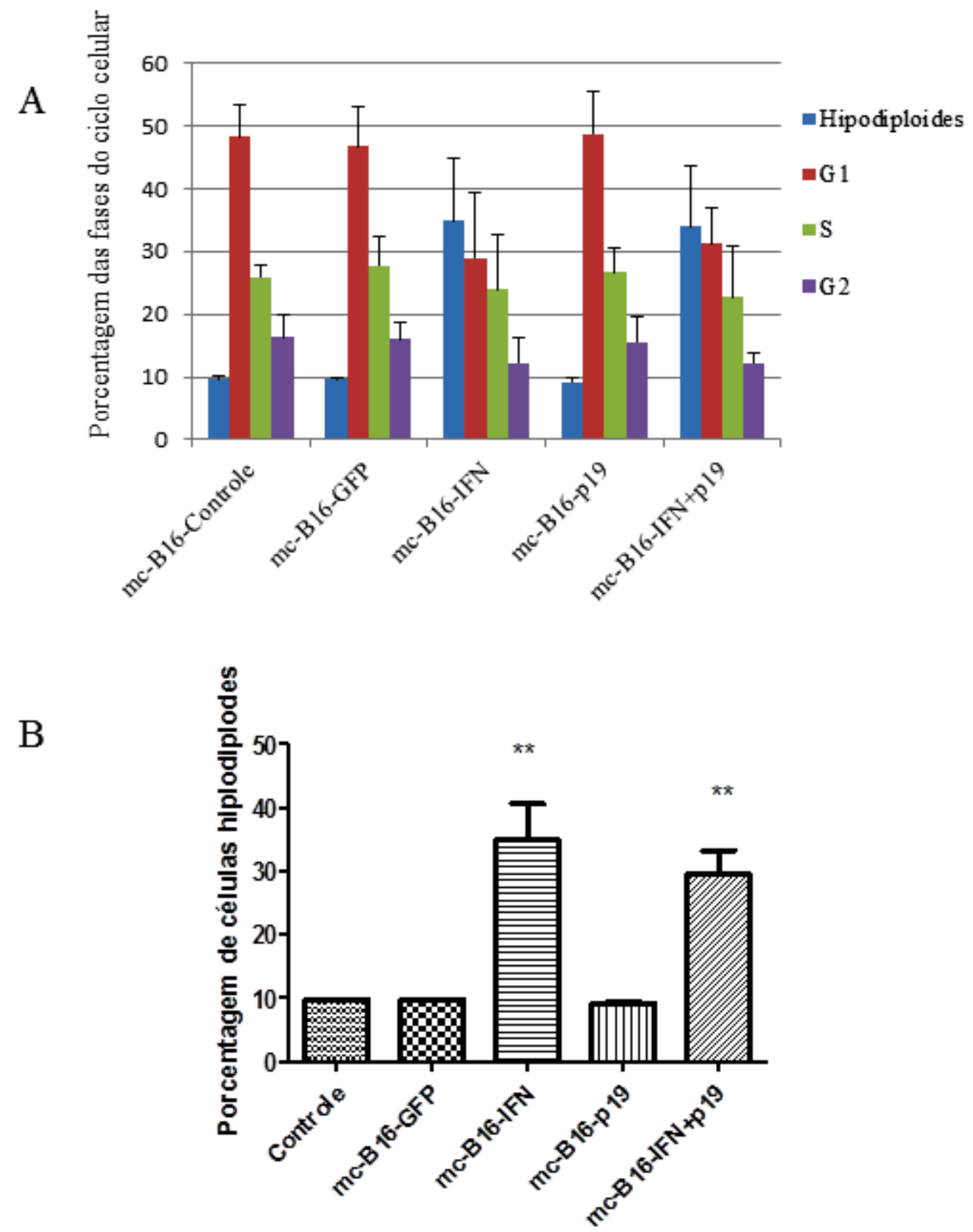

Figura 32: Ensaio de ciclo celular por citometria para a linhagem tEnd tratada com os meios condicionados da linhagem B16 transduzida com os vetores adenovirais. As células da linhagem tEnd foram cultivadas por 48 horas com meio condicionado proveniente da linhagem B16 transduzida com os vetores adenovirais. Após o tratamento, as células tEnd foram coletas e marcadas com P.I. (A) Gráfico com o ciclo celular da linhagem tEnd tratada com o meio condicionado. (B) Gráfico com a porcentagem de células hipodiploides do ensaio de ciclo celular das células da tEnd tratadas pelo meio condicionado.A analise do ciclo celular foi realizada por citometria de fluxo. Os resultados representam à média e o desvio padrão de três experimentos independentes. **p<0,01, ANOVA seguido do pós-teste-multi comparativo Tukey. 


\subsubsection{Ensaio de morte celular revelada por anexina e P.I. da linhagem tEnd tratada com o meio condicionado}

As células tEnd foram tratadas com os meios condicionados e após 48 horas, foram coletadas, marcadas com anexina + P.I. e analisadas por citometria de fluxo para identificar a porcentagem de células apoptóticas. Os resultados mostrados no gráfico abaixo demonstram que os meio condicionados; mc-B16-IFN e mc-B16-IFN+p19 induziram a uma maior porcentagem de células apoptóticas na linhagem tEnd, figura 33.

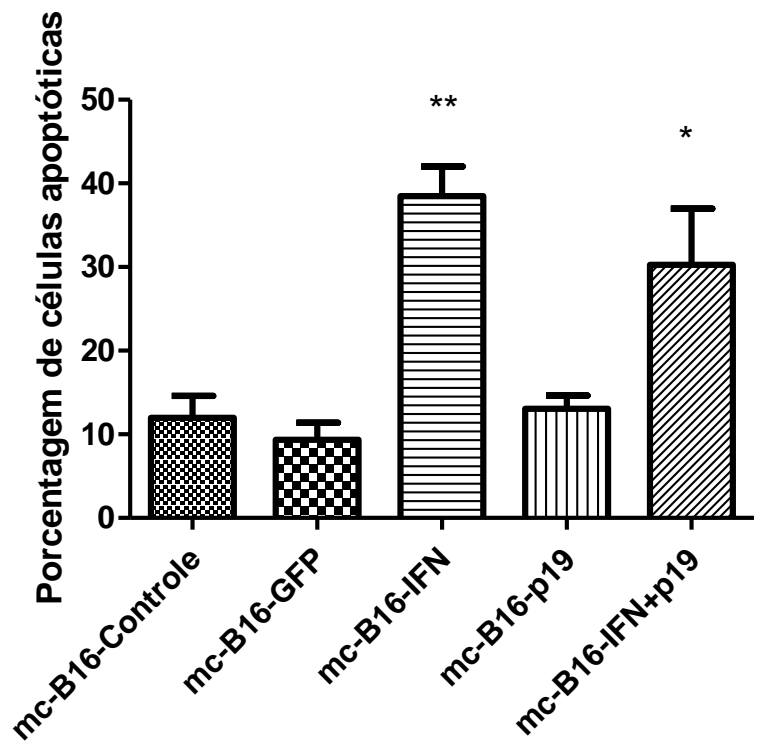

Figura 33: Porcentagem de células marcadas para AnexinaV e P.I da linhagem tEnd tratada com os meios condicionados da linhagem B16 transduzida com os vetores adenovirais. As células da linhagem tEnd foram tratadas com os meios condicionados por 48 horas, após tratamento foram marcadas com P.I. e anexinaV e analisadas para morte celular por citometria de fluxo (Attune- Life Technologies). Os dados representam a média e o desvio padrão de três experimentos independentes. $* * \mathrm{p}<0,01 \mathrm{e}$ *p<0,05, ANOVA seguido do pós-teste-multi comparativo Tukey. 


\section{DISCUSSÃO}

As células endoteliais são de suma importância para a sobrevivência do tumor, consideradas como as principais células dos vasos sanguíneos tumorais, são responsáveis pelo brotamento de novos vasos, controle da circulação sanguínea, são mediadoras das trocas de substâncias e células entre o tumor e o sistema, e amplamente estudadas na pesquisa envolvendo angiogênese tumoral (Dudley, 2012). Assim decidimos usar a linhagem endotelial tEnd para analisar os efeitos do tratamento com os vetores adenovirais portadores de IFN $\beta$ e p19Arf. Decidimos avaliar o impacto do tratamento com os vetores adenovirais portadores de IFN $\beta$ e p19Arf no comportamento das células endoteliais.

No presente trabalho, observamos que as células endoteliais tEnd apresentam transdução e expressão dos transgenes de modo confiável. De maneira geral, a combinação IFN $\beta$ e p19Arf não proporcionou efeito sinérgico nos ensaios de transdução direta ou de efeito parácrino. Mesmo assim, observamos que as células tEnd transduzidas diretamente com os vetores adenovirais Ad-p19 e com a combinação AdIFN+Ad-p19 resultaram na inibição da viabilidade, migração, formação de tubos e ainda induziu aumento de células hipodiploides e marcadas com Anexina-V, indicando evento de morte celular, consistente com apoptose. Nos ensaios de efeito parácrino, as células tumorais B16 transduzidas com os vetores adenovirais Ad-IFN e a combinação Ad-IFN+Ad-p19, na co-cultura ou através do meio condicionado, inibiram a proliferação das células tEnd, levaram a uma diminuição da viabilidade, proliferação e aumento na porcentagem de células hipodiploides e marcadas para AnexinaV. Ou seja, a presença do vetor Ad-p19 foi critico nos ensaios de transdução de células tEnd, entretanto a presença do vetor Ad-IFN foi decisivo nos ensaios de efeito parácrino. Esta 
dissertação sugere que o tratamento com os vetores adenovirais avaliados podem ter impacto na angiogênese tumoral através do seu efeito nas células endoteliais.

Os vetores adenovirais Ad-GFP, Ad-IFN e Ad-p19 foram construídos pelo pesquisador Christian A. Merkel (Merkel et al., 2013). Os vetores foram aprimorados graças aos esforços da aluna Aline Hunger Ribeiro (dissertação de mestrado e dados não publicados). A aluna alterou vetores adenovirais fornecidos por Mizuguchi (Mizuguchi et al., 2002) e transferiu os transgenes para esse vetor com inserção do tripeptideo RGD na proteína da Fibra adenoviral, que leva à interação do vetor com integrinas $\alpha / \beta$, aumentando a gama de tropismo do vetor.

Os vetores adenovirais Ad-GFP, Ad-IFN e Ad-p19 foram produzidos, titulados e obtivemos um bom titulo viral para realizarmos os ensaios in vitro, tabela 01. Após produzir e quantificar esses vetores, iniciamos os ensaios de validação dos vetores, para confirmarmos a capacidade de transdução e expressão dos transgenes.

Demonstramos que nossos vetores podem transduzir as células tumorais (B16, LLC e TM1) usadas no nosso laboratório e principalmente a linhagem endotelial (tEnd), os dados também mostram que a célula endotelial é transduzida com maior eficiência, quando comparado com as linhagens tumorais de melanoma.

Outros ensaios de validação para os transgenes IFN $\beta$, p19Arf e LacZ, confirmaram que nossos vetores transduzem e conferem expressão dos trangenes nas duas linhagens de maior foco desse projeto, B16 e tEnd. Com o ensaio de expressão gênica relativa por RTq-PCR, reforçamos a validação pela expressão relativa de IFN $\beta$ e p19Arf e nossos resultados mostraram que esses vetores induzem a uma forte expressão dos dois transgenes.

Depois de confirmar que os vetores transduzem e expressam seus transgenes, fizemos o ensaio de curva da eficiência de transdução usando quantidades crescentes de 
MOIs com o vetor Ad-GFP. Nesse ensaio foi possível constatar que a linhagem endotelial tEnd, apresenta maior eficiência de transdução, se comparado com as linhagens tumorais de melanoma B16 e TM1. Nossos vetores possuem a inserção do tripeptídeo RGD na proteína da Fibra, essa estrutura é responsável pelo tropismo do vírus. Essa inserção aumenta o poder do vetor de se ligar pelas integrinas $\alpha / \beta$ (Mizuguchi et al., 2002). Esse resultado é devido a alta quantidade de integrinas na membrana celular dessas células (Danhier et al., 2012). Frente a esses dados hipotetizamos que o tratamento com vetores adenovirais com a inserção do tripeptídeo RGD no capsídeo transduz mais eficientemente as células endoteliais, como já relatado pela literatura, onde trabalhos usando o tripeptídeo RGD acoplado a molécula terapêutica direciona esse tratamento diretamente para o endotélio vascular (Dettin et al., 2015; Li et al., 2008).

Após constatar que os nossos vetores demonstram alta eficiência de transdução pelas células endoteliais, iniciamos ensaios para averiguar a influência dos vetores em modular características angiogênicas da linhagem endotelial. Observamos no ensaio de proliferação que a estrutura do vetor adenoviral pode inibir a proliferação das células endoteliais da linhagem tEnd. O trabalho de (Wang et al., 2008), demonstrou em seus experimentos que a infecção por vetores adenovirais usados como controle, modula os processos mitogênicos das células e assim diminuem a proliferação. Entretanto, a transferência genica dos transgênes IFN $\beta$ e p19Arf não influenciaram na proliferação. Como o ensaio de migração ou mais comumente conhecido como "ensaio de risco" ou em inglês wound healing, é usado na pesquisa para avaliar a taxa de migração das células após tratamento (van der Meer et al., 2010). A migração das células endoteliais é essencial para a angiogênese, o movimento migratório das células reflete sua habilidade intrínseca de migrar para formar novos vasos sanguíneos (Michaelis, 2014) e o ensaio 
de tubologênese no matrigel, tem como objetivo avaliar alterações na angiogênese pela modulação de formação de tubos das células endoteliais tratadas. O ensaio de formação de tubos é um dos ensaios in vitro mais importantes nos estudos de angiogênese (Kornberg and Grant, 2007). Ambos ensaios são usando nas pesquisa in vitro para avaliar os efeitos pró ou anti-angiogênicos pelas células endoteliais (Guo et al., 2014). A transferência gênica mediada pelo vetor adenoviral portador de p19Arf, desacelerou a migração e formação de tubos das células tEnd, mesmo não retardando a proliferação, que pode influenciar na migração e formação de tubos. Os resultados demonstram que p19Arf retarda a movimentação migratória das células da linhagem tEnd e podemos inferir que a ativação da via de p53 ativada pela transferência gênica de p19Arf esteja relacionada com esse feito. Os trabalhos de (Guo et al., 2003) e (Debidda et al., 2006) mostraram em seus estudos que o aumento de p19arf e p53, pode diminuir significativamente a mobilidade celular e organização do citoesqueleto pela supressão de PI 3-Kinase e perda da atividade de Rac1 em células do microambiente.

Constatamos que a transferência gênica com p19Arf inibiu a migração e formação de tubos na nossa linhagem endotelial sem alterar a proliferação significativamente, então partimos para ensaios de viabilidade de morte celular da tEnd tratada com nossos vetores.

Após verificarmos que a transferência genica com p19Arf inibiu a sobrevivência das células da tEnd após transferência gênica no ensaio clonogênico, partimos para ensaios de viabilidade pela técnica de MTT, que é usado para quantificar a viabilidade das células após tratamento (Seidl and Zinkernagel, 2013). Fizemos a analise da viabilidade, após transdução com os vetores na linhagem endotelial tEnd. Neste ensaio verificamos que novamente a presença do transgene p19Arf foi preponderante na diminuição da viabilidade nas células endoteliais tEnd. Seguimos para os ensaios de 
ciclo celular e o ensaio de marcação de células apoptóticas que mostraram que a transdução com os vetores Ad-p19 e a co-transdução Ad-IFN+Ad-p19, aumentam a população de células hipodiploides no ciclo celular e também a porcentagem de células apoptóticas marcadas por Anexina-V/P.I. Ou seja, o gene p19Arf inserido nos vetores adenovirais, é responsável por reduzir a proliferação e induzir morte celular da tEnd.

Em recente trabalho publicado pelo nosso grupo (Merkel et al., 2013), o vetor Ad-IFN teve efeitos diretos no aumento da porcentagem de células apoptóticas do melanoma murino B16, porem esse vetor não apresentou efeitos anti-proliferativos nem indutores de morte na linhagem tEnd transduzida diretamente com os vetores.

Os dados resumidos até o momento apontam para um processo de morte consistente com apoptose. Com os ensaios de ciclo celular e marcação de células por AnexinaV+P.I., podemos hipotetizar que os vetores Ad-p19 e a co-transdução AdIFN+Ad-p19 induzem morte nas células endoteliais da linhagem tEnd e que o p19Arf é o transgene responsável por esses efeitos, enquanto o vetor Ad-IFN não afeta a proliferação e também não induz morte nas células endoteliais transduzidas diretamente.

O aumento da expressão de p53 nas células da linhagem tEnd tratadas com os vetores Ad-p19 e a co-transdução, mostram que o nível elevado de p19Arf na célula endotelial induz aumento desse gene e ativação transcricional de genes alvo de p53 como: MDM2, p21 e Puma. O aumento desses genes alvo nas células endoteliais foi observado apenas nas células tratadas com Ad-p19. Assim podemos considerar que, a transferência gênica com p19Arf é suficiente para aumentar a expressão de genes da via de p53 e modular a migração e formação de tubos e inbibir a viabilidade e induzir morte celular nas células endoteliais da linhagem tEnd. Como nos trabalhos de (el-Deiry, 1998; Zuckerman et al., 2009) foi visto que a proteína p53 induz a expressão de genes relacionados ao controle celular, tais como p21 e genes indutores de morte celular como 
PUMA ou em algumas ocasiões a p53 promove a apoptose sem a ativação de genes alvos, se ligando diretamente a proteínas na mitocôndria, alterando seu potencial transmenbrânico e conduzindo a célula a via intrínseca de apoptose.

A p53, conhecida como supressor tumoral, participa de vias importantes na regulação do ciclo celular, apoptose e reparo do DNA (Zhang et al., 2009). A ativação de p53 é fundamentalmente envolvida na angiogênese (Teodoro et al., 2007), seus efeitos na morte celular e ciclo faz com que a p53 tenha um futuro promissor em estratégias na terapia anti-tumoral (Li et al., 2012a). A p53 atua em várias vias através da indução de genes indutores de apoptose e por mecanismo independentes de transcrição (Zuckerman et al., 2009). De maneira direta, a p53 induz expressão de genes pró-apoptóticos como PUMA e Noxa (Nakano and Vousden, 2001; Shibue et al., 2003), a p53 ainda pode inibir a transcrição de genes anti-apoptóticos como Bcl-2 e Bcl-x, genes protetores da mitocôndria, com mecanismos que impedem a liberação do Citocromo C e da função ativadora das caspases (Vaseva and Moll, 2009). A p53 também pode levar a morte celular se ligando diretamente a proteínas na mitocôndria e alterando seu potencial transmenbranico (Mihara et al., 2003; Yang et al., 2015). Uma das ações de p53 em inibir a angiogênese foi elucidada pelos trabalhos de (Dameron et al., 1994) e (Reiher et al., 2001) que mostraram que a alta expressão de p53 aumenta consequentemente a produção de fatores anti-angiogênicos como a Trombospondina 1 (TSP-1) e do inibidor de angiogênese especifica de cérebro 1 (Bai-1) (Duda et al., 2002).

O microambiente tumoral do melanoma induzido pela linhagem B16 é constituído por $73 \%$ de células tumorais, $18 \%$ de células dos vasos sanguíneos e eritrócitos, $7 \%$ de elementos conectivos e 2\% de outras células e estruturas (Wosko et al., 1984). As células tumorais no melanoma murino, são a grande maioria das células 
no microambiente tumoral e é conhecido que os vetores adenovirais apresentão longa e forte expressão dos seus transgenes (Kreppel et al., 2002), frente a essas informações hipotetizamos que o tratamento com vetores adenovirais pode apresentar uma forte indução de resposta parácrina no microambiente tumoral.

A partir dessas informações, iniciamos os ensaios de co-cultura, com propósito de avaliarmos o efeito nas células endoteliais, em contato direto com as células tumorais de melanoma transduzidas pelos nossos vetores adenovirais. Esse ensaio tem como objetivo mimetizar a interação entre as células tumorais e endoteliais.

Para realizarmos o ensaio de co-cultura, foi necessário modificar uma das linhagens, com a inserção de um gene repórter e assim conseguirmos distinguir uma linhagem da outra na mesma placa.Utilizamos o vetor lentiviral Lego-iT2, para transduzir as células da linhagem tEnd e obter um clone que fosse de fácil identificação por fluorescência no microscópio EVOS. Selecionamos o clone que obteve melhor efeito de fluorescência da linhagem tEnd transduzida com o vetor Lego-iT2. Os clones das células da tEnd tranduzidas com o vetor lentiviral foram analisados por citometria de fluxo para selecionarmos o clone que fosse $100 \%$ marcado pela fluorescência vermelha (Dados não mostrados). Após conseguirmos o clone, nomeamos como tEndTO. Fizemos algumas imagens no microscópio EVOS para validar que no clone está $100 \%$ fluorescente, como nas figuras 25 e 26, mostram as células inteiramente fluorescentes e também fizemos a marcação com DAPI para confirmar que todas as células núcleo. $\mathrm{Na}$ figura $\mathbf{2 7}$, fizemos um ensaio piloto de co-cultura, onde transduzimos as células da linhagem B16 previamente com o vetor Ad-GFP, lavamos as células com PBS, e co-cultivamos essas células previamente transduzidas com as células da tEndTO. As imagens mostram somente a linhagem B16 com marcação para GFP e as células tEndTO fluorescentes para RFP (vermelho), demonstrando que a 
transdução previa da linhagem B16 é suficiente para realizarmos o ensaio de co-cultura onde somente as células da B16 tem contato com os vetores adenovirais.

No ensaio de co-cultura foram feitas imagens dos poços 24, 48 e 72 horas após semeadura das células. Os resultados mostraram que as células da linhagem B16 transduzidas com o vetor Ad-IFN, Ad-p19 e a co-transdução Ad-IFN+Ad-p19, mostraram menor número de células após o tratamento e as células tEndTO apresentaram uma redução significativa nos poços onde estiveram em contato com as células da linhagem B16 transduzidas com Ad-IFN e a co-transdução Ad-IFN+Ad-p19. Estes resultados indicam que a transferência pelo gene IFN $\beta$ induz as células tumorais da B16 a inibirem as células endoteliais tEnd que estão próximas, levando a um efeito parácrino.

Grandes esforços são feitos em estudos de secretômica, para identificar biomarcadores de células tumorais secretados sistemicamente e também avaliar a influência e função desses compostos (Xue et al., 2008). Nos ensaios usando o meio condicionado temos somente como objetivo avaliar os efeitos do meio condicionado composto por fatores secretados pelas células tumorais B16 transduzidas pelos vetores nas células endoteliais, sem identificarmos os compostos produzidos pelas células tumorais.

Frente aos resultados de inibição das células da tEndTO na co-cultura com as células da B16 previamente transduzidas com o vetor Ad-IFN, partimos para a produção de meio condicionado das células de melanoma B16 transduzidas com os vetores adenovirais portadores de IFN $\beta$ e p19Arf. Os ensaios com meio condicionado tiveram como objetivo, avaliar citotoxicidade, sobrevida, modulação do ciclo celular e indução de morte na célula tEnd tratada com o meio condicionado. Esses ensaios não foram possíveis de serem realizados no ensaio de co-cultura. 
Avaliamos o efeito do meio condicionado da linhagem de melanoma B16 transduzida pelos vetores e com o controle sem o vírus. Os meios de cultura provenientes das células transduzidas foram recolhidos e identificados. Estes meios condicionados foram utilizados como tratamento para a linhagem celular endotelial tEnd. Desse modo, mimetizamos o efeito parácrino com efeitos diretamente nas células endoteliais. O meios condicionados mc-B16-IFN e mc-B16-IFN+p19, induziram diminuição na viabilidade das células da tEnd e menor quantidade de colônias no ensaio clonogênico. Após verificarmos que o meio condicionado mc-b16-IFN e mc-b16IFN+p19 apresentou efeito anti-proliferativo para a tEnd, partimos para ensaios de ciclo celular e marcação de morte celular por Anexina / P.I., os resultados dos ensaios mostraram que os meios condicionados mc-B16-IFN e mc-B16-IFN+p19 também induziram maior porcentagem de células hipodiplóides no ciclo celular e maior quantidade de células apoptóticas.

Como visto no ensaio ELISA para o IFN $\beta$, figura 11, as células da linhagem B16 transduzidas pelo vetor Ad-IFN, produzem grande quantidade da proteína recombinante IFN $\beta$ no meio, diferente dos outros meios (mc-B16, mc-B16-GFP e mcB16-p19), esses resultados indicam que a presença da proteína Interferon-beta no meio condicionado pode induzir um efeito citotóxico, anti-proliferativo e indutor de morte nas células da linhagem endotelial tEnd. O resultado de ELISA na linhagem tEnd também mostrou alta expressão da Interferon-beta nas células transduzidas com vetores contendo IFN $\beta$, mas interessantemente essa citocina não afetou a própria célula. Podemos inferir que somente o Interferon-beta e/ou outros compostos desconhecidos produzidos pela linhagem B16 transduzida pelo vetor Ad-IFN induz efeito citotóxico nas células da linhagem tEnd. 
Outro trabalho usando meio condicionado de células de melanoma tratadas por transferência gênica usando plasmídeos com IFN $\beta$, mostraram forte efeito parácrino, capaz de induzir morte pelo meio condicionado, que apresentou ser rico em fatores citotóxicos solúveis, produzidos pelas células tumorais de melanoma transfectadas por IFN $\beta$ (Rossi et al., 2015). Mas não somente as células tumorais são alvo do efeito parácrino, os interferons alfa e beta demonstram efeito parácrino anti-tumoral significativo em induzir apoptose e inibir a angiogênese nas células vizinhas (Benedict et al., 2004). O trabalho de (Izawa et al., 2002b) usou células tumorais previamente transduzidas por vetores adenovirais portadores de IFN $\beta$, para induzir a formação de tumores em camundongos atímicos (imuno-deficientes), eles concluíram que houve retardo do crescimento tumoral devido a menor densidade de vasos, os resultados foram observados devido a maior indução de apoptose de células endoteliais.

A citocina IFN $\beta$ induz ativação de fatores transcricionais latentes conhecidos como STATs, levando a mudanças biológicas nas células tratadas com a citocina (Schindler et al., 2007). O IFN $\beta$ se liga ao receptor especifico IFNAR iniciando a fosforilação de STAT, essa molécula fosforilada é translocada para o núcleo e se liga ao DNA, promovendo a expressão de genes relacionados ao declínio da sobrevivência e proliferação (Gomez and Reich, 2003).

Os dados da literatura afirmam que o tratamento com IFN $\beta$ e p19Arf diminuem a produção de fatores pró-angiogênicos (Cao et al., 2001; Kawagishi et al., 2010; Vered et al., 2006). Com essas informações, avaliamos a expressão gênica de fatores próangiogênicos e esperávamos que a expressão desses fatores estivessem diminuídas nas células tEnd transduzidas com os vetores adenovirais portadores de IFN $\beta$ e p19Arf, porem nós observamos em nossos resultados um efeito contrario da literatura. 
A análise da expressão gênica para a expressão de fatores pró-angiogênicos nas células tEnd transduzidas com os vetores adenovirais portadores de IFN $\beta$, p19Arf ou a combinação, mostrou nos resultados um aumento na expressão do gene VEGF pela cotransdução e a transdução por p19Arf não mostrou resultados significativos, mas mostrou uma tendência a induzir expressão. A Angiopoetina também foi aumentada nas células tEnd transduzidas com a co-transdução e o vetor sozinho Ad-p19. Os ensaios de expressão dos genes da Ve-caderina e bFGF não foram significativos mas indicaram aumento nas células tEnd transduzidas com os três vetores Ad-IFN, Ad-p19 e a co-transdução. O fator de transcrição HIF-1 $\alpha$ pode induzir expressão de outros genes como o VEGF entre outros (Hellwig-Bürgel et al., 2005), nossos dados não foram significativos, mas indicam que a co-transdução e o vetor Ad-p19 induzem aumento da expressão de HIF-1a.

Os fatores pró-angiogênicos são conhecidos por induzir proliferação de células endoteliais e de células não endoteliais e consequentemente induzir a formação de novos vasos ou melhorar a qualidade desses vasos sanguíneos (Bouïs et al., 2006). O fator de crescimento VEGF, é o principal fator pró-angiogênico. O VEGF é um potente mitógeno e estimulador de sobrevivência das células, em especial para as células relacionadas à vasculatura dos vasos sanguíneos como as células endoteliais e os pericitos (Goel and Mercurio, 2013). As angiopoetinas ANG, são essenciais para o remodelamento e amadurecimento dos vasos sanguíneos. A ativação de receptores de angiopoetinas Tie-2, estimula uma gama de vias intracelulares relacionadas à sobrevivência pela proteção contra a morte por apoptose estimulando supressão da atividade de NFKB nas células endoteliais (Fagiani and Christofori, 2013). O fator de crescimento fibroblástico básico bFGF, tem ações relacionadas à sobrevivência, é um forte mitógeno, indutor de migração e produção de proteases relacionadas a formação 
de novos vasos (Sola et al., 1997). As caderinas de endotélio vascular VE-caderinas, são proteínas restritas às células endoteliais, relacionadas com a adesão celular, essenciais para a permeabilidade de substâncias e células dos vasos sanguíneos (Vestweber, 2008). O fator induzível por hipóxia - 1(HIF-1a) é geralmente ativado por condições de hipóxia, e funciona como fator de transcrição para genes pró-angiogênicos e inflamatórios (Hellwig-Bürgel et al., 2005).

O aumento na expressão dos fatores angiogênicos; VEGF, ANG, Ve-caderina e bFGF após transdução com os vetores adenovirais portadores de IFN $\beta$ e p19Arf, foi um resultado não esperado. O estresse celular pode induzir o aumento da expressão desses fatores (Goel et al., 2011), a ativação por p53 também é conhecida por regular a expressão de genes envolvidos em vários processos, como proliferação, sobrevida e angiogênese (Vousden and $\mathrm{Lu}, 2002$ ). P53 pode induzir MDM2 e a expressão de MDM2 também está correlacionada com o aumento no nível do VEGF (Narasimhan et al., 2008; Zietz et al., 1998). Apesar do aumento da expressão dos fatores próangiogênicos, esse fenômeno não foi suficiente para barrar os efeitos anti-proliferativos, anti-angiogênicos e indutores de morte celular da transdução com os vetores portadores de IFN $\beta$ e p19Arf nas células endoteliais tEnd. Considerando-se o balanço entre fatores pró e anti-proliferativos, a ativação da via de p53 se sobrepôs à ativação dos genes mitogênicos pró-angiogênicos.

Com os dados do projeto, podemos concluir que o tratamento com os dois vetores Ad-IFN e Ad-p19 são eficientes para inibir a angiogênese tumoral pelas células endoteliais. Os vetores transduzem mais eficientemente a célula endotelial do que as linhagens de melanoma. A causa desse efeito pode ser pela inserção do RGD no capsídeo do vetor, levando a uma alteração de tropismo dos vetores, direcionando-os para células com alta densidade de integrinas, que neste caso são as células endoteliais. 
De um modo geral, a transdução direta com o vetor Ad-p19 inibiu a viabilidade e direcionou as células da linhagem endotelial tEnd à morte, e nos ensaios de efeito parácrino, apenas o meio condicionado das células tumorais B16 tratadas com Ad-IFN inibiram a viabilidade e levaram as células endoteliais tEnd a morte celular. Podemos inferir que a combinação dos dois vetores adenovirais Ad-IFN e Ad-p19 trabalham de formas diferentes, mas que seus efeitos anti-angiogênicos são complementares em inibir o processo angiogênico mediado pelas células endoteliais. 


\section{CONCLUSÃO}

Os resultados apresentados neste trabalho, indicam que o tratamento com os vetores adenovirais portadores de IFN $\beta$ e p19Arf são eficientes em inibir a angiogênese direcionada pelas células endoteliais. O tratamento direto com vetores adenovirais portadores de p19Arf reduziu as características angiogênicas e direcionou a células tEnd a morte, já o vetor Ad-IFN reduziu a viabilidade e levou as células da tEnd a morte em ensaios de efeito parácrino pela linhagem de melanoma B16 transduzida. 


\section{REFERÊNCIAS}

Bajgelman, M. C., and B. E. Strauss, 2008, Development of an adenoviral vector with robust expression driven by p53: Virology, v. 371, p. 8-13.

Benedict, W. F., Z. Tao, C. S. Kim, X. Zhang, J. H. Zhou, L. Adam, D. J. McConkey, A. Papageorgiou, M. Munsell, J. Philopena, H. Engler, W. Demers, D. C. Maneval, C. P. Dinney, and R. J. Connor, 2004, Intravesical Ad-IFNalpha causes marked regression of human bladder cancer growing orthotopically in nude mice and overcomes resistance to IFN-alpha protein: Mol Ther, v. 10, p. 525-32.

Bergers, G., and L. E. Benjamin, 2003, Tumorigenesis and the angiogenic switch: Nat Rev Cancer, v. 3, p. 401-10.

Boudreau, N., and C. Myers, 2003, Breast cancer-induced angiogenesis: multiple mechanisms and the role of the microenvironment: Breast Cancer Res, v. 5, p. 140-6.

Bouter, A., R. Carmeille, C. Gounou, F. Bouvet, S. A. Degrelle, D. Evain-Brion, and A. R. Brisson, 2015, Review: Annexin-A5 and cell membrane repair: Placenta, v. 36 Suppl 1, p. S43-9.

Bouïs, D., Y. Kusumanto, C. Meijer, N. H. Mulder, and G. A. Hospers, 2006, A review on pro- and anti-angiogenic factors as targets of clinical intervention: Pharmacol Res, v. 53, p. 89-103.

Browder, T., C. E. Butterfield, B. M. Kraling, B. Shi, B. Marshall, M. S. O'Reilly, and J. Folkman, 2000, Antiangiogenic scheduling of chemotherapy improves efficacy against experimental drug-resistant cancer: Cancer Res, v. 60, p. 1878-86.

Brown, C. J., S. Lain, C. S. Verma, A. R. Fersht, and D. P. Lane, 2009, Awakening guardian angels: drugging the p53 pathway: Nat Rev Cancer, v. 9, p. 862-73.

Burch, L. R., M. Scott, E. Pohler, D. Meek, and T. Hupp, 2004, Phage-peptide display identifies the interferon-responsive, death-activated protein kinase family as a novel modifier of MDM2 and p21WAF1: J Mol Biol, v. 337, p. 115-28.

Cao, G., J. Su, W. Lu, F. Zhang, G. Zhao, D. Marteralli, and Z. Dong, 2001, Adenovirus-mediated interferon-beta gene therapy suppresses growth and metastasis of human prostate cancer in nude mice: Cancer Gene Ther, v. 8, p. 497-505.

Carmeliet, P., 2005, Angiogenesis in life, disease and medicine: Nature, v. 438, p. 9326.

Carmeliet, P., and R. K. Jain, 2011, Molecular mechanisms and clinical applications of angiogenesis: Nature, v. 473, p. 298-307.

Cho, Y. R., and M. P. Chiang, 2010, Epidemiology, staging (new system), and prognosis of cutaneous melanoma: Clin Plast Surg, v. 37, p. 47-53.

Clemens, M. J., 2003, Interferons and apoptosis: J Interferon Cytokine Res, v. 23, p. 277-92.

Cristofanilli, M., C. Charnsangavej, and G. N. Hortobagyi, 2002, Angiogenesis modulation in cancer research: novel clinical approaches: Nat Rev Drug Discov, v. 1, p. 415-26.

Dameron, K. M., O. V. Volpert, M. A. Tainsky, and N. Bouck, 1994, Control of angiogenesis in fibroblasts by p53 regulation of thrombospondin-1: Science, v. 265 , p. $1582-4$. 
Danhier, F., V. Pourcelle, J. Marchand-Brynaert, C. Jérôme, O. Feron, and V. Préat, 2012, Targeting of tumor endothelium by RGD-grafted PLGA-nanoparticles: Methods Enzymol, v. 508, p. 157-75.

Debidda, M., D. A. Williams, and Y. Zheng, 2006, Rac1 GTPase regulates cell genomic stability and senescence: J Biol Chem, v. 281, p. 38519-28.

Dettin, M., A. Zamuner, M. Roso, G. Iucci, V. Samouillan, R. Danesin, M. Modesti, and M. T. Conconi, 2015, Facile and selective covalent grafting of an RGDpeptide to electrospun scaffolds improves HUVEC adhesion: J Pept Sci, v. 21, p. 786-95.

Drewes, C. C., R. Y. Dias, V. G. Branco, M. F. Cavalcante, J. G. Souza, D. S. Abdalla, A. M. Chudzinski-Tavassi, and S. H. Farsky, 2015, Post-transcriptional control of Amblyomin-X on secretion of vascular endothelial growth factor and expression of adhesion molecules in endothelial cells: Toxicon, v. 101, p. 1-10.

Duda, D. G., M. Sunamura, L. Lozonschi, T. Yokoyama, T. Yatsuoka, F. Motoi, A. Horii, K. Tani, S. Asano, Y. Nakamura, and S. Matsuno, 2002, Overexpression of the p53-inducible brain-specific angiogenesis inhibitor 1 suppresses efficiently tumour angiogenesis: Br J Cancer, v. 86, p. 490-6.

Dudley, A. C., 2012, Tumor endothelial cells: Cold Spring Harb Perspect Med, v. 2, p. a006536.

Eccles, S. A., W. Court, L. Patterson, and S. Sanderson, 2009, In vitro assays for endothelial cell functions related to angiogenesis: proliferation, motility, tubular differentiation, and proteolysis: Methods Mol Biol, v. 467, p. 159-81.

Eichhorn, M. E., A. Kleespies, M. K. Angele, K. W. Jauch, and C. J. Bruns, 2007, Angiogenesis in cancer: molecular mechanisms, clinical impact: Langenbecks Arch Surg, v. 392, p. 371-9.

el-Deiry, W. S., 1998, Regulation of p53 downstream genes: Semin Cancer Biol, v. 8, p. 345-57.

Ellis, L. M., and D. J. Hicklin, 2008, VEGF-targeted therapy: mechanisms of antitumour activity: Nat Rev Cancer, v. 8, p. 579-91.

Fagiani, E., and G. Christofori, 2013, Angiopoietins in angiogenesis: Cancer Lett, v. 328 , p. 18-26.

Fatyol, K., and A. A. Szalay, 2001, The p14ARF tumor suppressor protein facilitates nucleolar sequestration of hypoxia-inducible factor-1alpha (HIF-1alpha ) and inhibits HIF-1-mediated transcription: J Biol Chem, v. 276, p. 28421-9.

Ferreira C, and R. J, 2004, Oncologia Molecular, v. 1, p. 437 - 445.

Fischer, I., J. P. Gagner, M. Law, E. W. Newcomb, and D. Zagzag, 2005, Angiogenesis in gliomas: biology and molecular pathophysiology: Brain Pathol, v. 15, p. 297310.

Floros, T., and A. A. Tarhini, 2015, Anticancer Cytokines: Biology and Clinical Effects of Interferon- $\alpha 2$, Interleukin (IL)-2, IL-15, IL-21, and IL-12: Semin Oncol, v. 42, p. 539-48.

Folkman, J., 2007, Angiogenesis: an organizing principle for drug discovery?: Nat Rev Drug Discov, v. 6, p. 273-86.

Franken, N. A., H. M. Rodermond, J. Stap, J. Haveman, and C. van Bree, 2006, Clonogenic assay of cells in vitro: Nat Protoc, v. 1, p. 2315-9.

Gerhardt, H., M. Golding, M. Fruttiger, C. Ruhrberg, A. Lundkvist, A. Abramsson, M. Jeltsch, C. Mitchell, K. Alitalo, D. Shima, and C. Betsholtz, 2003, VEGF guides angiogenic sprouting utilizing endothelial tip cell filopodia: J Cell Biol, v. 161, p. 1163-77. 
Ghigo, D., M. Arese, R. Todde, A. Vecchi, F. Silvagno, C. Costamagna, Q. G. Dong, M. Alessio, R. Heller, R. Soldi, F. Trucco, G. Garbarino, G. Pescarmona, A. Mantovani, F. Bussolino, and A. Bosia, 1995, Middle T antigen-transformed endothelial cells exhibit an increased activity of nitric oxide synthase: J Exp Med, v. 181, p. 9-19.

Giglia-Mari, G., and A. Sarasin, 2003, TP53 mutations in human skin cancers: Hum Mutat, v. 21, p. 217-28.

Gimbrone, M. A., Jr., S. B. Leapman, R. S. Cotran, and J. Folkman, 1973, Tumor angiogenesis: iris neovascularization at a distance from experimental intraocular tumors: J Natl Cancer Inst, v. 50, p. 219-28.

Goel, H. L., and A. M. Mercurio, 2013, VEGF targets the tumour cell: Nat Rev Cancer, V. 13, p. 871-82.

Goel, S., D. G. Duda, L. Xu, L. L. Munn, Y. Boucher, D. Fukumura, and R. K. Jain, 2011, Normalization of the vasculature for treatment of cancer and other diseases: Physiol Rev, v. 91, p. 1071-121.

Goers, L., P. Freemont, and K. M. Polizzi, 2014, Co-culture systems and technologies: taking synthetic biology to the next level: J R Soc Interface, v. 11.

Gomez, D., and N. C. Reich, 2003, Stimulation of primary human endothelial cell proliferation by IFN: J Immunol, v. 170, p. 5373-81.

Guo, F., Y. Gao, L. Wang, and Y. Zheng, 2003, p19Arf-p53 tumor suppressor pathway regulates cell motility by suppression of phosphoinositide 3-kinase and Rac1 GTPase activities: J Biol Chem, v. 278, p. 14414-9.

Guo, S., J. Lok, Y. Liu, K. Hayakawa, W. Leung, C. Xing, X. Ji, and E. H. Lo, 2014, Assays to examine endothelial cell migration, tube formation, and gene expression profiles: Methods Mol Biol, v. 1135, p. 393-402.

Gupta, K., and J. Zhang, 2005, Angiogenesis: a curse or cure?: Postgrad Med J, v. 81, p. 236-42.

Hamm, C., S. Verma, T. Petrella, K. Bak, and M. Charette, 2008, Biochemotherapy for the treatment of metastatic malignant melanoma: a systematic review: Cancer Treat Rev, v. 34, p. 145-56.

Hanahan, D., and R. A. Weinberg, 2000, The hallmarks of cancer: Cell, v. 100, p. 5770.

Hellwig-Bürgel, T., D. P. Stiehl, A. E. Wagner, E. Metzen, and W. Jelkmann, 2005, Review: hypoxia-inducible factor-1 (HIF-1): a novel transcription factor in immune reactions: J Interferon Cytokine Res, v. 25, p. 297-310.

Hirschi, K. K., and P. A. D'Amore, 1996, Pericytes in the microvasculature: Cardiovasc Res, v. 32, p. 687-98.

Hussussian, C. J., J. P. Struewing, A. M. Goldstein, P. A. Higgins, D. S. Ally, M. D. Sheahan, W. H. Clark, Jr., M. A. Tucker, and N. C. Dracopoli, 1994, Germline p16 mutations in familial melanoma: Nat Genet, v. 8, p. 15-21.

Hynes, R. O., 2009, The extracellular matrix: not just pretty fibrils: Science, v. 326, p. 1216-9.

INCA, I. N. d. C., 2014, Relatório Anual de 2014: Disponível em: <http:// www.cancer.org.br/relatorio-anual>, v. Acess: 06 de Outubro . 2014.

Izawa, J. I., L. T. Madsen, S. M. Scott, J. P. Tran, E. J. McGuire, A. C. Von Eschenbach, and L. L. Pisters, 2002a, Salvage cryotherapy for recurrent prostate cancer after radiotherapy: variables affecting patient outcome: J Clin Oncol, v. 20, p. 2664-71.

Izawa, J. I., P. Sweeney, P. Perrotte, D. Kedar, Z. Dong, J. W. Slaton, T. Karashima, K. Inoue, W. F. Benedict, and C. P. Dinney, 2002b, Inhibition of tumorigenicity 
and metastasis of human bladder cancer growing in athymic mice by interferonbeta gene therapy results partially from various antiangiogenic effects including endothelial cell apoptosis: Clin Cancer Res, v. 8, p. 1258-70.

Junttila, M. R., and F. J. de Sauvage, 2013, Influence of tumour micro-environment heterogeneity on therapeutic response: Nature, v. 501, p. 346-54.

Kamb, A., D. Shattuck-Eidens, R. Eeles, Q. Liu, N. A. Gruis, W. Ding, C. Hussey, T. Tran, Y. Miki, J. Weaver-Feldhaus, and et al., 1994, Analysis of the p16 gene (CDKN2) as a candidate for the chromosome 9p melanoma susceptibility locus: Nat Genet, v. 8, p. 23-6.

Kavanagh, D., A. D. Hill, B. Djikstra, R. Kennelly, E. M. McDermott, and N. J. O'Higgins, 2005, Adjuvant therapies in the treatment of stage II and III malignant melanoma: Surgeon, v. 3, p. 245-56.

Kawagishi, H., H. Nakamura, M. Maruyama, S. Mizutani, K. Sugimoto, M. Takagi, and M. Sugimoto, 2010, ARF suppresses tumor angiogenesis through translational control of VEGFA mRNA: Cancer Res, v. 70, p. 4749-58.

Kornberg, L. J., and M. B. Grant, 2007, Adenoviruses increase endothelial cell proliferation, migration, and tube formation: partial reversal by the focal adhesion kinase inhibitor, FRNK: Microvasc Res, v. 73, p. 157-62.

Kreppel, F., T. T. Luther, I. Semkova, U. Schraermeyer, and S. Kochanek, 2002, Longterm transgene expression in the RPE after gene transfer with a high-capacity adenoviral vector: Invest Ophthalmol Vis Sci, v. 43, p. 1965-70.

Lee, J., A. Wang, Q. Hu, S. Lu, and Z. Dong, 2006, Adenovirus-mediated interferonbeta gene transfer inhibits angiogenesis in and progression of orthotopic tumors of human prostate cancer cells in nude mice: Int J Oncol, v. 29, p. 1405-12.

Li, H., T. Lakshmikanth, E. Carbone, and G. Selivanova, 2012a, A novel facet of tumor suppression by p53: Induction of tumor immunogenicity: Oncoimmunology, v. 1, p. 541-543.

Li, J., M. Ding, Q. Fu, H. Tan, X. Xie, and Y. Zhong, 2008, A novel strategy to graft RGD peptide on biomaterials surfaces for endothelization of small-diamater vascular grafts and tissue engineering blood vessel: J Mater Sci Mater Med, v. 19 , p. 2595-603.

Li, W. W., V. W. Li, M. Hutnik, and A. S. Chiou, 2012b, Tumor angiogenesis as a target for dietary cancer prevention: J Oncol, v. 2012, p. 879623.

Liang, C. C., A. Y. Park, and J. L. Guan, 2007, In vitro scratch assay: a convenient and inexpensive method for analysis of cell migration in vitro: Nat Protoc, v. 2, p. 329-33.

Merkel, C. A., R. B. da Silva Soares, A. C. de Carvalho, D. B. Zanatta, M. C. Bajgelman, P. Fratini, E. Costanzi-Strauss, and B. E. Strauss, 2010, Activation of endogenous p53 by combined p19Arf gene transfer and nutlin-3 drug treatment modalities in the murine cell lines B16 and C6: BMC Cancer, v. 10, p. 316.

Merkel, C. A., R. F. Medrano, V. G. Barauna, and B. E. Strauss, 2013, Combined p19Arf and interferon-beta gene transfer enhances cell death of B16 melanoma in vitro and in vivo: Cancer Gene Ther, v. 20, p. 317-25.

Meyer, N., J. Christoph, H. Makrinioti, P. Indermitte, C. Rhyner, M. Soyka, T. Eiwegger, M. Chalubinski, K. Wanke, H. Fujita, P. Wawrzyniak, S. Burgler, S. Zhang, M. Akdis, G. Menz, and C. Akdis, 2012, Inhibition of angiogenesis by IL-32: possible role in asthma: J Allergy Clin Immunol, v. 129, p. 964-73 e7.

Michaelis, U. R., 2014, Mechanisms of endothelial cell migration: Cell Mol Life Sci, v. 71, p. 4131-48. 
Mihara, M., S. Erster, A. Zaika, O. Petrenko, T. Chittenden, P. Pancoska, and U. M. Moll, 2003, p53 has a direct apoptogenic role at the mitochondria: Mol Cell, v. 11, p. $577-90$.

Minn, A. J., 2015, Interferons and the Immunogenic Effects of Cancer Therapy: Trends Immunol.

Mizuguchi, H., N. Koizumi, T. Hosono, A. Ishii-Watabe, E. Uchida, N. Utoguchi, Y. Watanabe, and T. Hayakawa, 2002, CAR- or alphav integrin-binding ablated adenovirus vectors, but not fiber-modified vectors containing RGD peptide, do not change the systemic gene transfer properties in mice: Gene Ther, v. 9, p. 769-76.

Mizuguchi, H., N. Koizumi, T. Hosono, N. Utoguchi, Y. Watanabe, M. A. Kay, and T. Hayakawa, 2001, A simplified system for constructing recombinant adenoviral vectors containing heterologous peptides in the HI loop of their fiber knob: Gene Ther, v. 8, p. 730-5.

Nakano, K., and K. H. Vousden, 2001, PUMA, a novel proapoptotic gene, is induced by p53: Mol Cell, v. 7, p. 683-94.

Narasimhan, M., R. Rose, R. Ramakrishnan, J. A. Zell, and A. Rathinavelu, 2008, Identification of HDM2 as a regulator of VEGF expression in cancer cells: Life Sci, v. 82, p. 1231-41.

Noseda, M., L. Chang, G. McLean, J. E. Grim, B. E. Clurman, L. L. Smith, and A. Karsan, 2004, Notch activation induces endothelial cell cycle arrest and participates in contact inhibition: role of p21Cip1 repression: Mol Cell Biol, v. 24, p. 8813-22.

Pozarowski, P., and Z. Darzynkiewicz, 2004, Analysis of cell cycle by flow cytometry: Methods Mol Biol, v. 281, p. 301-11.

Rebecca, V. W., V. K. Sondak, and K. S. Smalley, 2012, A brief history of melanoma: from mummies to mutations: Melanoma Res, v. 22, p. 114-22.

Reiher, F. K., M. Ivanovich, H. Huang, N. D. Smith, N. P. Bouck, and S. C. Campbell, 2001, The role of hypoxia and p53 in the regulation of angiogenesis in bladder cancer: J Urol, v. 165, p. 2075-81.

Roh, M. R., Z. Zheng, H. S. Kim, H. C. Jeung, S. Y. Rha, and K. Y. Chung, 2013, Difference of interferon-alpha and interferon-beta on melanoma growth and lymph node metastasis in mice: Melanoma Res, v. 23, p. 114-24.

Rossi, Ú., M. L. Gil-Cardeza, M. S. Villaverde, L. M. Finocchiaro, and G. C. Glikin, 2015 , Interferon- $\beta$ gene transfer induces a strong cytotoxic bystander effect on melanoma cells: Biomed Pharmacother, v. 72, p. 44-51.

Sabel, M. S., and V. K. Sondak, 2003, Pros and cons of adjuvant interferon in the treatment of melanoma: Oncologist, v. 8, p. 451-8.

Saharinen, P., L. Eklund, K. Pulkki, P. Bono, and K. Alitalo, 2011, VEGF and angiopoietin signaling in tumor angiogenesis and metastasis: Trends Mol Med, v. 17 , p. 347-62.

Sandoval, R., J. Xue, M. Pilkinton, D. Salvi, H. Kiyokawa, and O. R. Colamonici, 2004, Different requirements for the cytostatic and apoptotic effects of type I interferons. Induction of apoptosis requires ARF but not p53 in osteosarcoma cell lines: J Biol Chem, v. 279, p. 32275-80.

Sato, M., T. Taniguchi, and N. Tanaka, 2001, The interferon system and interferon regulatory factor transcription factors -- studies from gene knockout mice: Cytokine Growth Factor Rev, v. 12, p. 133-42.

Satyamoorthy, K., and M. Herlyn, 2002, Cellular and molecular biology of human melanoma: Cancer Biol Ther, v. 1, p. 14-7. 
Schindler, C., D. E. Levy, and T. Decker, 2007, JAK-STAT signaling: from interferons to cytokines: J Biol Chem, v. 282, p. 20059-63.

Seidl, K., and A. S. Zinkernagel, 2013, The MTT assay is a rapid and reliable quantitative method to assess Staphylococcus aureus induced endothelial cell damage: J Microbiol Methods, v. 92, p. 307-9.

Sennino, B., T. Ishiguro-Oonuma, Y. Wei, R. M. Naylor, C. W. Williamson, V. Bhagwandin, S. P. Tabruyn, W. K. You, H. A. Chapman, J. G. Christensen, D. T. Aftab, and D. M. McDonald, 2012, Suppression of tumor invasion and metastasis by concurrent inhibition of c-Met and VEGF signaling in pancreatic neuroendocrine tumors: Cancer Discov, v. 2, p. 270-87.

Shibue, T., K. Takeda, E. Oda, H. Tanaka, H. Murasawa, A. Takaoka, Y. Morishita, S. Akira, T. Taniguchi, and N. Tanaka, 2003, Integral role of Noxa in p53mediated apoptotic response: Genes Dev, v. 17, p. 2233-8.

Sitohy, B., J. A. Nagy, and H. F. Dvorak, 2012, Anti-VEGF/VEGFR therapy for cancer: reassessing the target: Cancer Res, v. 72, p. 1909-14.

Sola, F., A. Gualandris, M. Belleri, R. Giuliani, D. Coltrini, M. Bastaki, M. P. Tosatti, F. Bonardi, A. Vecchi, F. Fioretti, M. Ciomei, M. Grandi, A. Mantovani, and M. Presta, 1997, Endothelial cells overexpressing basic fibroblast growth factor (FGF-2) induce vascular tumors in immunodeficient mice: Angiogenesis, v. 1, p. 102-116.

Soufir, N., M. F. Avril, A. Chompret, F. Demenais, J. Bombled, A. Spatz, D. StoppaLyonnet, J. Benard, and B. Bressac-de Paillerets, 1998, Prevalence of p16 and CDK4 germline mutations in 48 melanoma-prone families in France. The French Familial Melanoma Study Group: Hum Mol Genet, v. 7, p. 209-16.

Stockmann, C., A. Doedens, A. Weidemann, N. Zhang, N. Takeda, J. I. Greenberg, D. A. Cheresh, and R. S. Johnson, 2008, Deletion of vascular endothelial growth factor in myeloid cells accelerates tumorigenesis: Nature, v. 456, p. 814-8.

Strauss, B. E., M. C. Bajgelman, and E. Costanzi-Strauss, 2005, A novel gene transfer strategy that combines promoter and transgene activities for improved tumor cell inhibition: Cancer Gene Ther, v. 12, p. 935-46.

Strauss, B. E., and E. Costanzi-Strauss, 2004, pCLPG: a p53-driven retroviral system: Virology, v. 321, p. 165-72.

Sumpio, B. E., J. T. Riley, and A. Dardik, 2002, Cells in focus: endothelial cell: Int J Biochem Cell Biol, v. 34, p. 1508-12.

Takaoka, A., S. Hayakawa, H. Yanai, D. Stoiber, H. Negishi, H. Kikuchi, S. Sasaki, K. Imai, T. Shibue, K. Honda, and T. Taniguchi, 2003, Integration of interferonalpha/beta signalling to p53 responses in tumour suppression and antiviral defence: Nature, v. 424, p. 516-23.

Teodoro, J. G., S. K. Evans, and M. R. Green, 2007, Inhibition of tumor angiogenesis by p53: a new role for the guardian of the genome: J Mol Med (Berl), v. 85, p. 1175-86.

Ulanet, D. B., and D. Hanahan, 2010, Loss of p19(Arf) facilitates the angiogenic switch and tumor initiation in a multi-stage cancer model via p53-dependent and independent mechanisms: PLoS One, v. 5, p. e12454.

van der Meer, A. D., K. Vermeul, A. A. Poot, J. Feijen, and I. Vermes, 2010, A microfluidic wound-healing assay for quantifying endothelial cell migration: Am J Physiol Heart Circ Physiol, v. 298, p. H719-25.

Vaseva, A. V., and U. M. Moll, 2009, The mitochondrial p53 pathway: Biochim Biophys Acta, v. 1787, p. 414-20. 
Vered, M., A. Buchner, and D. Dayan, 2006, Giant cell granuloma of the jawbones--a proliferative vascular lesion? Immunohistochemical study with vascular endothelial growth factor and basic fibroblast growth factor: J Oral Pathol Med, v. 35, p. 613-9.

Vestweber, D., 2008, VE-cadherin: the major endothelial adhesion molecule controlling cellular junctions and blood vessel formation: Arterioscler Thromb Vasc Biol, v. 28, p. 223-32.

Vousden, K. H., and X. Lu, 2002, Live or let die: the cell's response to p53: Nat Rev Cancer, v. 2, p. 594-604.

Wang, Z., T. Mitsui, M. Ishida, and J. Arita, 2008, Adenovirus vectors differentially modulate proliferation of pituitary lactotrophs in primary culture in a mitogen and infection time-dependent manner: J Endocrinol, v. 198, p. 209-17.

Williams, R. L., S. A. Courtneidge, and E. F. Wagner, 1988, Embryonic lethalities and endothelial tumors in chimeric mice expressing polyoma virus middle $\mathrm{T}$ oncogene: Cell, v. 52, p. 121-31.

Wosko, T. J., D. T. Ferrara, and L. S. Sartori, 1984, Histological comparison of the B16 melanoma and its F1 variant: Cancer Lett, v. 24, p. 57-63.

Xiao, H. B., W. Y. Zhou, X. F. Chen, J. Mei, Z. W. Lv, F. B. Ding, G. Q. Li, H. Zhong, and C. R. Bao, 2012, Interferon- $\beta$ efficiently inhibited endothelial progenitor cell-induced tumor angiogenesis: Gene Ther, v. 19, p. 1030-4.

Xue, H., B. Lu, and M. Lai, 2008, The cancer secretome: a reservoir of biomarkers: J Transl Med, v. 6, p. 52.

Yamashita, M., A. Ino, K. Kawabata, F. Sakurai, and H. Mizuguchi, 2007, Expression of coxsackie and adenovirus receptor reduces the lung metastatic potential of murine tumor cells: Int J Cancer, v. 121, p. 1690-6.

Yang, F. C., G. Merlino, and L. Chin, 2001, Genetic dissection of melanoma pathways in the mouse: Semin Cancer Biol, v. 11, p. 261-8.

Yang, Y., L. Jiang, Y. She, M. Chen, Q. Li, G. Yang, C. Geng, L. Tang, L. Zhong, and X. Liu, 2015, Olaquindox induces DNA damage via the lysosomal and mitochondrial pathway involving ROS production and p53 activation in HEK293 cells: Environ Toxicol Pharmacol, v. 40, p. 792-799.

Yoshida, J., M. Mizuno, M. Fujii, Y. Kajita, N. Nakahara, M. Hatano, R. Saito, M. Nobayashi, and T. Wakabayashi, 2004, Human gene therapy for malignant gliomas (glioblastoma multiforme and anaplastic astrocytoma) by in vivo transduction with human interferon beta gene using cationic liposomes: Hum Gene Ther, v. 15, p. 77-86.

Zhang, L., J. Zhang, C. Hu, J. Cao, X. Zhou, Y. Hu, Q. He, and B. Yang, 2009, Efficient activation of p53 pathway in A549 cells exposed to L2, a novel compound targeting p53-MDM2 interaction: Anticancer Drugs, v. 20, p. 416-24.

Zheng, H., J. Qian, C. J. Carbone, N. A. Leu, D. P. Baker, and S. Y. Fuchs, 2011, Vascular endothelial growth factor-induced elimination of the type 1 interferon receptor is required for efficient angiogenesis: Blood, v. 118, p. 4003-6.

Zietz, C., M. Rössle, C. Haas, A. Sendelhofert, A. Hirschmann, M. Stürzl, and U. Löhrs, 1998, MDM-2 oncoprotein overexpression, p53 gene mutation, and VEGF upregulation in angiosarcomas: Am J Pathol, v. 153, p. 1425-33.

Zuckerman, V., K. Wolyniec, R. V. Sionov, S. Haupt, and Y. Haupt, 2009, Tumour suppression by p53: the importance of apoptosis and cellular senescence: J Pathol, v. 219, p. 3-15. 


\section{ANEXO 1}

Aprovação pelo comitê de ética.

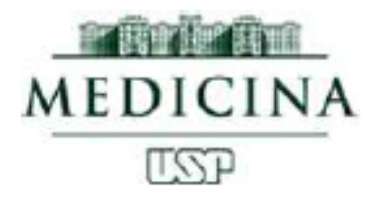

COMISSÃo DE ÉTICA NO USO DE ANIMAIS

A CEUA da Faculdade de Medicina da Universidade de São Paulo, em sessão de 23/10/2014, APROVOU o Protocolo de Pesquisa no 147/14 intitulado: "Avaliação da vasculatura tumoral após tratamento em um modelo murino de melanoma com vetores adenovirais portadores de interferonbeta e p19ARF" que utilizará 300 animais da espécie camundongo, apresentado pelo Departamento de Radiologia e Oncologia.

Cabe ao pesquisador elaborar e apresentar à CEUA-FMUSP, o relatório final sobre a pesquisa, (Lei Procedimentos para o Uso Científico de Animais - Lei No 11.794 -8 de outubro de 2008).

Pesquisador (a) Responsável: Bryan Eric Strauss

Pesquisador (a) Executante: Igor de Luna Vieira

CEUA-FMUSP, 23 de Outubro de 2014

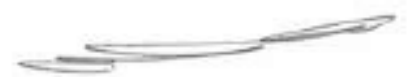

Dr. Eduardo Pompeu

Coordenador

Comissão de Ética no Uso de Animais 


\section{ANEXO 2}

Carta de aprovação da CEUA para mudança de título.

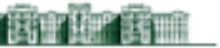 MEDICINA TSP COMISSÃO DE ÉTICA NO USO DE ANIMAIS}

A CEUA da Faculdade de Medicina da Universidade de São Paulo, $\mathrm{em}$ 05/o2/16, $\triangle$ PROVOU o documento abaixo mencionado, datado de 04/02/16, para o Protocolo de Pesquisa $\mathbf{n}^{\circ} \mathbf{1 4 7 / 1 4}$, intitulado: "Avaliação da vasculatura tumoral após tratamento em um modelo murino de melanoma com vetores adenovirais portadores de interferon-beta e p19ARF", apresentado pelo Departamento de Radiologia e Oncologia.

- Alteração no título do projeto para: "Avaliação na linhagem endotelial tEnd dos efeitos diretos da transferência gênica de IFN $\beta$ e p19art e efeitos parácrinos mediados pela linhagem B16 transduzida pelos mesmos vetores adenovirais"

Pesquisador Responsável: Bryan Eric Strauss

Pesquisador Executante: Igor de Luna Vieira

CEUA-FMUSP, o5 de Fevereiro de 2016

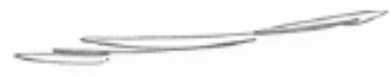

Dr. Eduardo Pompeu

Coordenador

Comissão de Ética no Uso de Animais

Comissắ de Ética no Uso de Animals da FMUSP

e-mail: ceua.fm@usp.br 


\section{ANEXO 3}

Atividades Acadêmicas.

Durante o período do mestrado pelo Programa de Oncologia realizei algumas atividades acadêmicas como.

\section{Cursos realizados:}

X Curso Avançado de Patogênese do HIV. (Carga horária: 30h).

Faculdade de Medicina da Universidade de São Paulo, FMUSP, Brasil.

Oratória e Técnicas de Apresentação. (Carga horária: 16h).

Roma Treinamentos, ROMA, Brasil.

Biologia Molecular Expressão Gênica e Polimorfismo. (Carga horária: 40h).

Instituto do Câncer do Estado de São Paulo, ICESP, Brasil.

\section{Produção bibliográfica:}

VIEIRA, I. L; STRAUSS, B. E. . Avaliação da vasculatura tumoral após tratamento em um modelo murino de melanoma com vetores adenovirais portadores de interferon beta e p19 ARF. In: Congresso de Hematologia, 2013, Brasília. Avaliação da vasculatura tumoral após tratamento em um modelo murino de melanoma com vetores adenovirais portadores de interferon beta e p19 ARF, 2013. Congresso Brasileiro de Hematologia, Hematoterapia e Terapia Celular. 2013.

\section{Produção didática}

Aula sobre angiogênese tumoral gravada no III Curso de Oncologia Molecular da FMUSP, disponível on-line e gratuita.

http://www.cursooncologia.com.br/angiogenese-tumoral/

\section{$\underline{\text { Participação em eventos }}$}

VII Jornada da Pós-graduação em Oncologia da FMUSP.Avaliador de painel. 2015. (Simpósio).

VII Jornada da Pós-graduação em Oncologia da FMUSP. 2015. (Simpósio).

VI Jornada da Pós-Graduação em Oncologia da FMUSP. 2014. (Simpósio).

Congresso Brasileiro de Hematologia, Hematoterapia e Terapia Celular. 2013.

(Congresso).

Next Frontiers to Cure Cancer- Integrating Science and Patient Care. 2013. (Congresso).

V Jornada da Pós-Graduação em Oncologia da FMUSP. 2013. (Simpósio). 
$\underline{\text { Cursos oferecidos }}$

Curso de Cultura Celular dentro do III Curso de Oncologia Molecular da FMUSP

$\underline{\text { Organização de eventos }}$

III Curso em Oncologia Molecular da FMUSP. 2015.

VII Jornada da Pós-graduação da FMUSP. 2015.

IV Curso em Oncologia Molecular da FMUSP. 2017 


\section{ANEXO 4}

Capítulo do Livro Fundamentos em Oncologia Molecular para Graduação.

VIEIRA, IGOR DE LUNA; TAMURA, RODRIGO; CHAMMAS, ROGER. . In: CHAMMAS, Roger et al. Fundamentos em Oncologia Molecular para Graduação. 01. ed. São Paulo: Atheneu, 2015. Cap. Angiogênese Tumoral. p. 233-254. 


\section{2 ANGIOGÊNESE TUMORAL}

\section{Igor de Luna Vieira, Rodrigo Esaki Tamura e Roger Chammas}

\section{INTRODUÇÃO}

No ano de 1955, Thomlinson e Gray analisaram tecidos tumorais e observaram que a difusão radial do oxigênio em tecidos sólidos, ocorre a uma distância máxima de até $150 \mu \mathrm{m}$ a $200 \mu \mathrm{m}$ dos capilares, a partir dessa distância as células do tecido tumoral começam a apresentar sinais de anoxia e necrose.

Mais tarde em 1971, Judah Folkman propôs o fenômeno da angiogênese tumoral, demonstrando que os tumores desenvolveram mecanismos para induzir a formação de novos vasos para poderem progredir. Portanto, sugerindo que agentes anti-angiogênicos podem ser potentes agentes antitumorais.

As células tumorais, como as demais células necessitam de um constante suporte de nutrientes, trocas gasosas, retiradas de metabólitos. Este suporte é em parte garantido por difusão e em parte por vasos sanguíneos, que também servem como portas de entrada e saída para o sistema imune e migração de células provenientes da medula óssea. A ativação da angiogênese nos tumores é essencial para a tumorigênese, pois a massa tumoral não ultrapassa o tamanho de $2 \mathrm{~mm}^{3}$, permanecendo em um estado dormente, se o tumor não apresentar esta função. Ainda, a vasculatura tumoral pode facilitar a disseminação de metástases pelo corpo.

Ao final deste capítulo espera-se que o leitor compreenda: (i) o papel da angiogênese tumoral como fator fundamental para evolução do tumor, (ii) o mecanismo geral e molecular do formação de vasos, (iii) a influência do estroma e do sistema imune na angiogênese, (iv) as características únicas dos vasos tumorais e sua influência na metástase, (v) a plasticidade das células tumorais no mimetismo de vascularização e, (vi) tratamentos angiogênicos atuais.

\section{DESTAQUES:}

- Importância da vasculatura tumoral para o tumor.

- Difusão do oxigênio pelo tecido.

- Tumores com característica angiogênica são mais agressivos. 


\section{MECANIMOS GERAIS DA ANGIOGÊNESE TUMORAL}

O sistema circulatório é formado durante a embriogênese, através da vasculogênese são formados o coração e os primeiros vasos sanguíneos, incluindo os vasos placentários, a partir desses primeiros vasos pré-existentes ocorre uma remodelação da rede através da angiogênese. Nos adultos esses processos só voltam a ocorrer normalmente no reparo tecidual e durante o ciclo reprodutivo feminino.

Diferente da formação dos vasos normais determinados através de processos fisiológicos, a arquitetura da vasculatura tumoral é principalmente definida por "interações heterotípicas" entre as células vasculares (células endoteliais, pericitos e células da musculatura lisa) e células não vasculares (células tumorais e do estroma).

Existem 3 subdivisões do fenômeno do crescimento da vasculatura do tumor: a angiogênese, que envolve o brotamento a partir de vasos pré-existentes, a vasculogênese pela construção de vasos a partir de células provenientes da medula óssea e a arteriogênese na maturação dos vasos pela migração de células da musculatura lisa e pericitos.

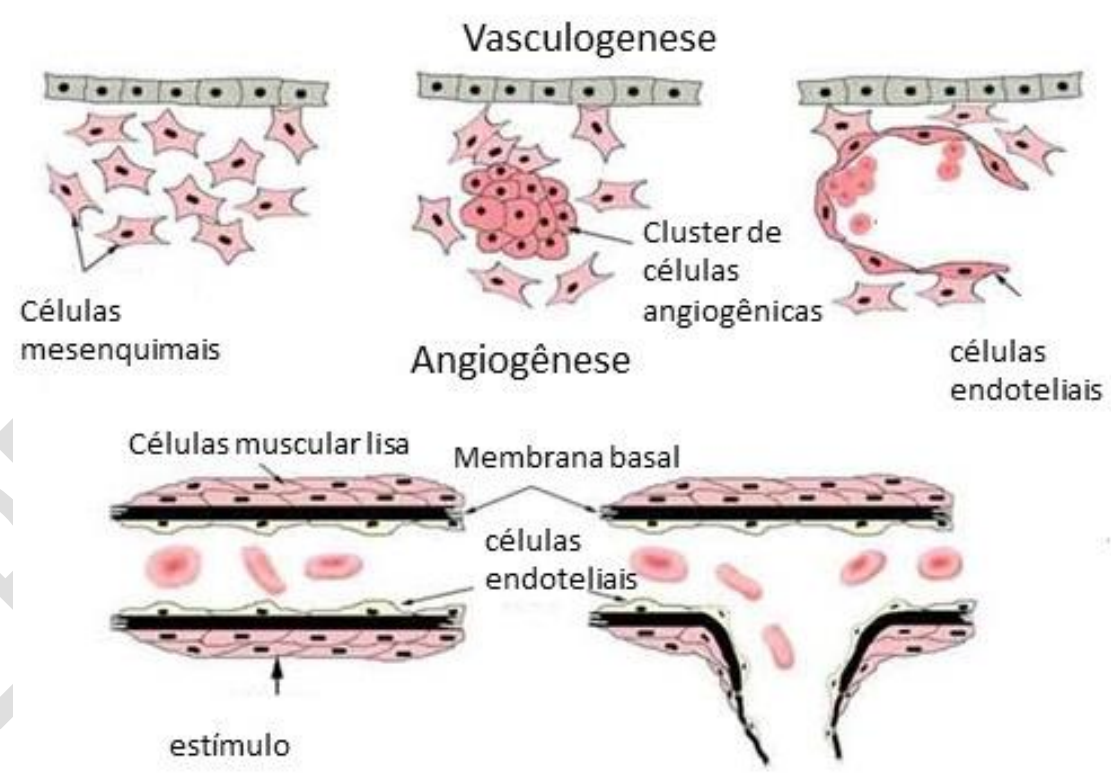

Interações heterotípicas: são interações entre células de diferentes tipos.

Células endoteliais (CEs:) formam o lúmen dos capilares, são circundadas por pericitos e células da musculatura lisa.

Pericitos: são derivados de células mesenquimais, tem a função de auxiliar as células endoteliais $e$ produzem fatores responsáveis pela homeostase dos vasos.
Figura 12.1. Angiogênese e Vasculogenese. Vasculogênese é a formação de novos vasos por células progenitoras. Angiogênese é a ramificação de vasos préexistentes. Modificado de Chinoy MR, Lung growth and development Frontiers in Bioscience 8, 392-415, January 1, 2003. 
O complexo processo de indução de angiogênese tumoral acontece pela combinação de eventos simultâneos envolvendo células tumorais e não tumorais, entre os quais devem ser destacados: (A) Baixa concentração de oxigênio, condição conhecida como hipóxia, que estimula as células locais a aumentar a produção de fatores pró-angiogênicos. (B)Sinalização extracelular estimulando células endoteliais. Sinais estimulatórios liberados pelas células tumorais e não tumorais no microambiente induzem quebra da homeostasia entre os fatores pró e anti-angiogênicos, promovendo mudanças em múltiplos tipos celulares e estimulando as células endoteliais (CEs) próximas ao microambiente tumoral a iniciar processo de divisão, migração e a formação de novos capilares em direção à fonte de estimulo pró-angiogênico. (C) Recrutamento de células precursoras. Tumores sólidos liberam fatores quimiotáticos e recrutam células provenientes da medula óssea, que migram para o sítio tumoral ou metastático e auxiliam a tumorigênese, tanto através da produção de fatores de crescimento, como pela diferenciação em células da vasculatura tumoral complementando a construção de novos vasos do tumor. (D) Presença de inflamação tumoral. A inflamação no microambiente tumoral recruta uma gama de células especificas entre as quais estão as células inflamatórias que liberam fatores solúveis pró-angiogênicos. (E) Mimetismo de vascularização. As células tumorais apresentam uma grande plasticidade, de modo que elas próprias também podem formar um sistema de canais de vascularização ao mimetizarem células vasculares em mecanismo dependente e independente dos vasos tumorais. Dessa maneira, inúmeros tipos celulares além das células endoteliais participam na construção dessa rede de vascularização do tumor.
Hipóxia: é o estado de baixo teor de oxigênio em um tecido.

Anoxia é a privação total de oxigenação

Plasticidade tumoral: é a característica que os tumores têm em se adaptar, resistir a outros ambientes ou adquirir outras características. 


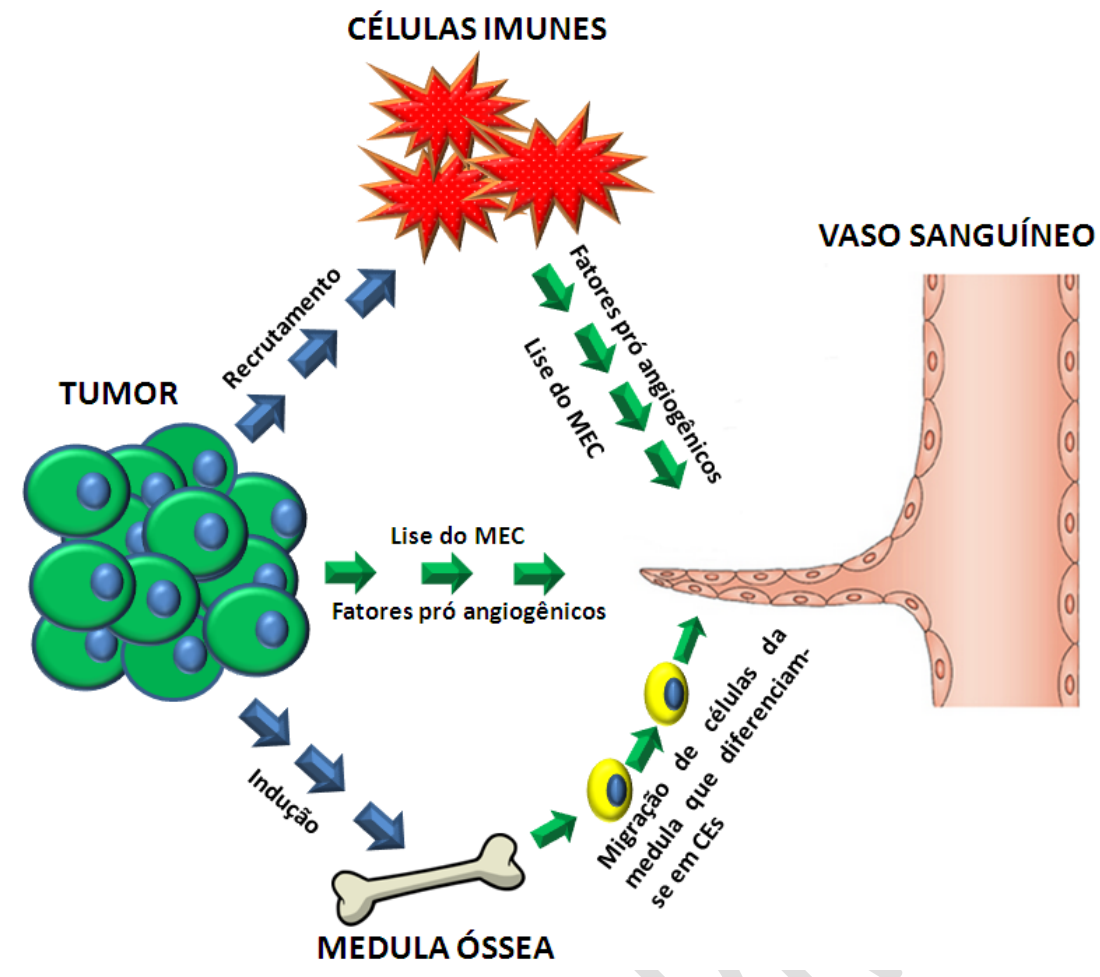

ANGIOGÊNESE

TUMORAL: MOLECULARES

Durante a homeostasia e em processos fisiológicos normais os fatores pró e anti-angiogênicos encontram-se em equilíbrio. Porém no momento em que esse equilíbrio é deslocado em favor dos fatores pró-angiogênicos, dispara-se o "gatilho angiogênico", momento em que o tumor começa a induzir angiogênese. Alguns dos fatores pró-angiogênicos incluem os fatores de crescimento de endotélio vascular (VEGF), fator de crescimento derivado de plaqueta (PDGF), fatores de crescimento fibroblasticos (FGFs) e muitos outros.

Esses fatores pró-angiogênicos podem ser produzidos tanto por células tumorais, quanto outras células do microambiente tumoral, como também podem já se encontrar presentes, mas sequestradas em condições normais na matriz extracelular (MEC). O aumento ou liberação desses fatores costuma ocorrer em condições de hipóxia, acidose, mutações genéticas com ativação de oncogenes ou inativação de supressores de tumor e ativação de resposta imune inflamatória.

\section{Indução de fatores pró-angiogênicos}

O microambiente tumoral apresenta regiões de normóxia, onde o fornecimento de oxigênio e nutrientes é normal e regiões de hipóxia, localizadas em áreas mais distantes dos vasos tumorais, onde o suprimento inadequado de nutrientes, altos
Figura 12.2. Eventos indutores de angiogênese. Células tumorais liberam fatores pró-angiogênicos, além de recrutarem células do sistema imune e estimularem as células provenientes de células endoteliais da medula óssea.

Gatilho angiogênico: condição fisio(pato)lógica, em que há ativação da formação de vasos a partir de sinais frequentemente estromais.

Matriz extracelular (MEC): é composta de colágenos, fibronectina, proteoglicanos $e$ outros, que fornecem suporte $e$ sustentação para os tecidos, cada tecido apresenta composições diferentes, criando microambientes diferenciados.

Normóxia: é o estado de oxigenação normal de um tecido. 
níveis de dióxido de carbono, lixo metabólico e baixo $\mathrm{pH}$ contribuem para a morte das células próximas.

Para corrigir essa situação de hipóxia, as células tumorais produzem o fator induzido por hipóxia 1 (HIF-1), que funciona como um fator de transcrição de fatores de crescimento, essa proteína é responsável por forçar o retorno das condições de normóxia, como consequência induz a angiogênese via transcrição de uma gama de fatores pró-mitóticos e angiogênicos como os fatores de crescimento de endotélio vascular (VEGFs).

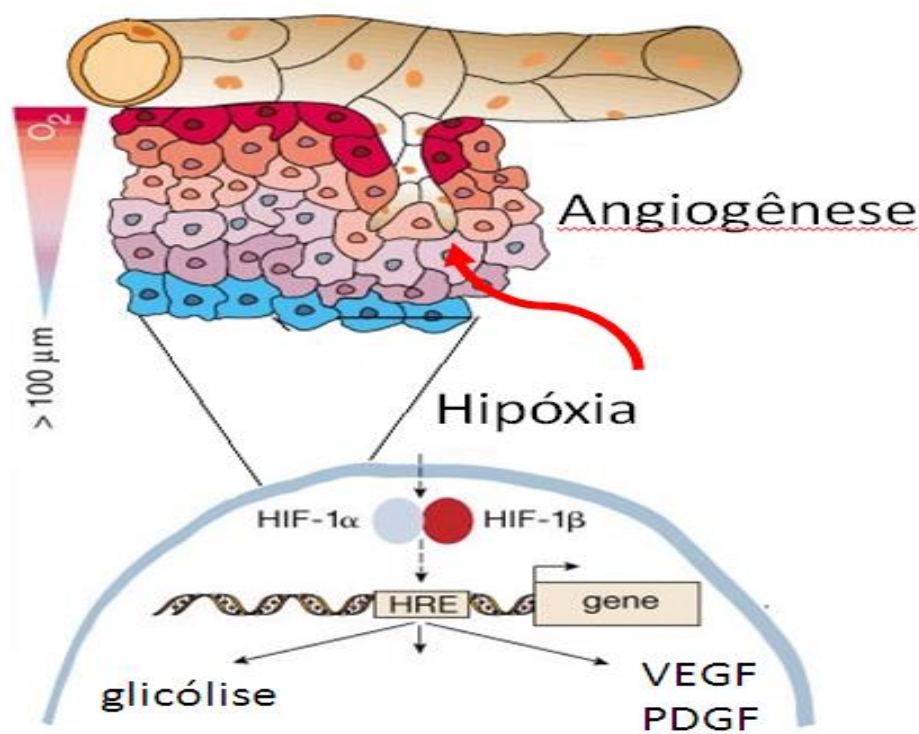

O VEGF, é o fator pró-angiogênico mais estudado e caracterizado pela literatura cientifica, possui grande importância na angiogênese e na tumorigênese, estudos mostram que se o gene do VEGF for deletado do genótipo das células tumorais, o tumor não consegue adquirir o fenótipo angiogênico e crescer além de $2 \mathrm{~mm}^{3}$ e nem mesmo as células do estroma conseguem compensar a sua produção.

Os fatores VEGF-A e VEGF-B possuem diversas funções na angiogênese como, alargamento, ramificação, brotamento dos vasos e manutenção da homeostase vascular. Essas funções são iniciadas quando os fatores se ligam aos seus respectivos receptores, VEGFR1 (Flt1), que é um fraco sinalizador e VEGFR2 (Flt2, KDR), forte indutor de sinais. Diferentes trabalhos mostram uma relação direta entre fatores próangiogênicos e a malignidade do tumor, de modo que a densidade de vasos está diretamente relacionada com as taxas de VEGF.

Os receptores do fator de crescimento epidérmico (EGFR/HER-2) encontram-se alterados em diversos tumores e sua alta ativação induz a expressão de genes como o VEGF e bFGF, que induzem angiogênese.
Fatores de transcrição: são proteínas regulatórias, cuja principal função é a ativação da transcrição de determinado grupo de genes.

Fatores pró-mitóticos: proteínas relacionadas com a progressão do ciclo celular.

Figura 12.3. Hipóxia induz ativação de HIF-1, que induz a expressão de genes relacionados com a angiogênese. Modificado de: Carmeliet $\mathrm{P}$ and Jain $\mathrm{R} \mathrm{K}$. Angiogenesis in cancer and other diseases. Nature 2000; 407,249-257. 
Outro fator pró-angiogênico importante é o fator de crescimento derivado de plaqueta (PDGF), que está envolvido na vasculogênese e arteriogênese. Este fator liga-se a um receptor tirosino-quinase (PDGFR), ativando-o e promovendo a progressão do ciclo celular e migração. Este fator tem como principal função angiogênica a maturação dos vasos recentes, atraindo células da musculatura lisa dos vasos e pericitos. Os PDGFs também participam do recrutamento dos progenitores de pericitos perivasculares da medula óssea.

Os fatores de crescimento de fibroblasto (FGFs) possuem propriedades na angiogênese e arteriogênese. A ativação dos receptores específicos, FGFRs, em células endoteliais e outras do microambiente induzem proliferação e diferenciação, além de manter a indução de angiogênese diretamente por induzir essas células a produzir outros fatores angiogênicos, como o VEGF.

As angiopoetinas participam da manutenção dos vasos e da arteriogênese pelo estimulo e recrutamento de pericitos para os vasos recém-formados. A angiopoetina1(ANG1) tem função pró-angiogênica, participando da maturação dos vasos, migração, adesão e sobrevivência das células endoteliais, já a angiopoetina2 (ANG2) funciona de maneira anti-angiogênica, ao romper a interação entre o endotélio e as células perivasculares e promovendo a morte celular. Ambas se ligam ao mesmo receptor Tie2, expresso especificamente no tecido endotelial vascular.

As Efrinas e Semaforinas são responsáveis pela distribuição organizada dos vasos no tumor, tendo funções de separar os vasos e deixá-los em distancias confortáveis para distribuição do oxigênio e nutrientes que estes vasos vão promover.

As integrinas presentes nas células endoteliais (ECs), tem um importante papel na manutenção do processo de angiogêngese, essas proteínas de membrana estão em contato direto com a matriz extracelular. As integrinas funcionam em cooperação com receptores de fatores de crescimento ou de citocinas; e, sua função está em determinar se a célula está em um ambiente apropriado para sobrevida, migração ou invasão.

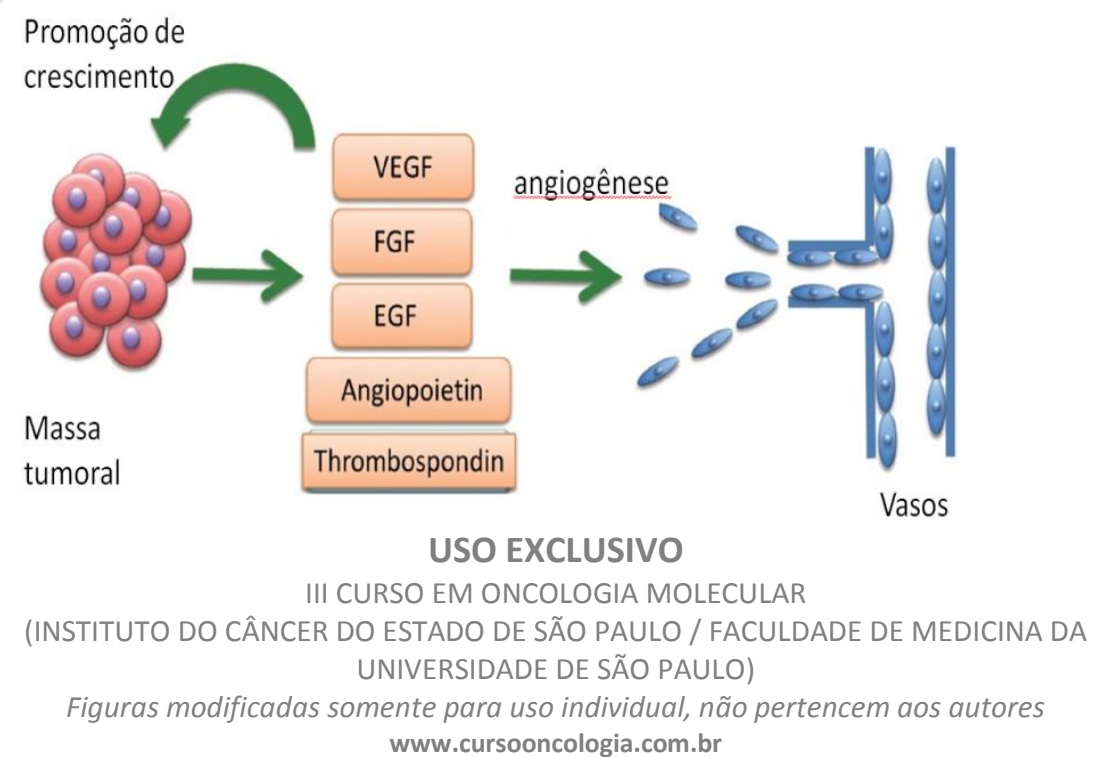

Integrinas: família de proteínas transmembranas que intermediam a interação da célula e da MEC, integrando sinais extracelulares, que serão transduzidos intracelularmente.

Figura 12.4. Fatores relacionados com a angiogênese. As células tumorais liberam diferentes fatores pró-angiogênicos, como VEGF, FGF, EGF e outros, que promovem a angiogênese tumoral. Modificado de: Leyva-Illades D, McMillin M, Quinn M, DeMorrow S. Cholangiocarcinoma pathogenesis: Role of the tumor microenvironment. Transl Gstrointest Cancer 2012;1:71-80. 


\section{Liberação de fatores pró-angiogênicos}

Em alguns modelos tumorais, mesmo que não haja aumento de expressão de fatores como VEGF foi observado o aumento da presença de fatores pró-angiogênicos. Isso ocorre pela ação de metaloproteinases (MMPs), proteases que dissociam a MEC e iniciam a liberação de fatores de crescimento vascular, como o VEGF, que normalmente fica sequestrado na matriz. A liberação desses fatores induz a formação de novos vasos.

A degradação da matriz ainda é necessária para abrir espaço para a migração dos novos capilares sanguíneos em direção a esta fonte dos fatores angiogênicos, favorecendo a proliferação dos pericitos e células musculares lisas que vão completar esses novos vasos tornando-os maduros.

Uma importante fonte de MMPs são células do sistema imune. As células tumorais do microambiente inflamado recrutam células inflamatórias como mastócitos e macrófagos que atuam com caráter pró-tumoral ao liberarem MMPs.

\section{Fatores anti-angiogênicos}

Em contra-partida, existem vários inibidores da angiogênese que inibem essa característica, podendo até destruir os vasos, como o caso da proteína trombospondina - 1 (Tsp-1), proteína secretada por vários tipos de células incluindo as tumorais, seu efeito é via FasL, que ativa sinalização de morte por apoptose pela via de caspases em células endoteliais que estão se multiplicando ou que formaram vasos recentes e ainda não estão maduras (sem a cobertura por pericitos e células da musculatura lisa).

A proteína Tsp-1 é induzida pelo supressor de tumor p53. Quando está ativo, p53 funciona como um indutor de parada na proliferação celular e crescimento do tumor. Sendo um dos genes mais frequentemente mutados em diferentes formas de câncer. Estudos mostram que a perda da função de p53 em tumores leva a uma acentuada diminuição da produção de Tsp-1 e conseqüente indução de angiogênese.

As proteínas inibidoras de tecido de metaloproteinase (TIMPs) representam outro importante inibidor angiogênico que inibem as MMPs e impedem o alongamento de capilares mediado pela MEC via ligação com integrinas de superfície celular que desligam a sinalização dos receptores de VEGF, MMPs e FGF.

\section{Mecanismo de formação de novos vasos}

O brotamento de novos vasos no tumor ocorre através de um mecanismo de células da extremidade (tip cells) e células-

\author{
Metaloproteínases de matriz \\ (MMPs): endopeptidases que \\ participam da degradação de \\ proteínas da MEC.
}


eixo (stalk cells). O processo se inicia com a ativação de células que assumem o papel de liderança na organização do brotamento- estas células iniciadoras de brotamento (células de extremidade) emitem protrusões citoplasmáticas, filopódias, em resposta a ativação de vias de sinalização de VEGF, deflagrando por sua vez a sinalização de DLL4, ligante de Notch.

$\mathrm{O}$ fator VEGF-A interage com o receptor VEGFR2 presente na célula endotelial da extremidade, nessas células que iniciam o fenótipo de células de extremidade, ocorre o aumento da produção da proteína de membrana DLL4, que se liga ao receptor Notch-1 da célula vizinha (célula-eixo). O Notch-1 ativado por DLL4 bloqueia a produção de VEGFR2, levando as células-eixo endoteliais a cessarem os estímulos angiogênicos, mesma na presença de altos níveis de VEGFs. O fator Notch-1 ativado aumenta a produção de VEGFR1, que tem alta afinidade por VEGFs, embora este receptor ativo seja dispensável para angiogênese.

Nesse mecanismo proposto, as células da extremidade expressam altos níveis de DLL4 e VEGFR2, o que as torna não proliferativas e ao mesmo tempo apresentam filopodia com ramificações se extendendo por quimiotaxia em direção à fonte de estímulo angiogênico. A célula-eixo por sua vez prolifera e promove a aproximação da célula de extremidade ao estímulo angiogênico.

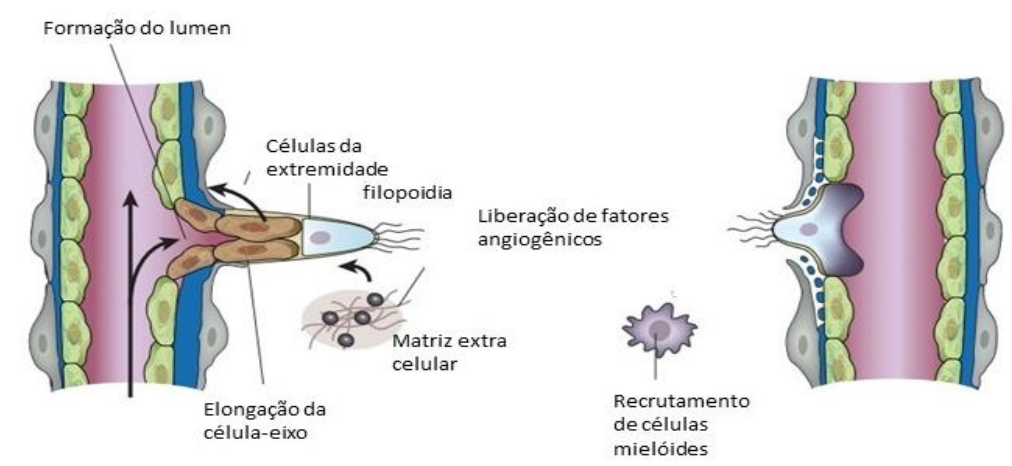

As caderinas de endotelio vascular (VE-caderinas) são componentes transmembrana vitais, envolvidas na adesão dependente de cálcio entre as células endoteliais e promovem estabilização dos vasos por inibição dos sinais de VEGFR2 e ativam as vias de TGF $\beta$. Estas moléculas estão localizadas na membrana entre células adjacentes e são reguladas pela concentração de oxigênio, quando em um ambiente de hipóxia são endocitadas. A redução das caderinas entre as células causa uma ruptura da monocamada das células endoteliais e essa dissociação da estrutura funciona como suporte para formação de novos vasos. A presença das caderinas na filopodia das células da extremidade garante a estabilização do brotamento de novos vasos.
Células iniciadoras de brotamento ou da extremidade (tip cells): são células endoteliais que recebem toda a gama de fatores pró angiogenicos $e$ iniciam $o$ brotamento de novos vasos em direção à fonte de estímulos.

Filopódia: protrusão citoplasmática que inicia o processo de migração celular em direção à fonte de estímulos. Evidencia-se durante a formação de novos vasos, onde estruturas finas e filamentosas são formadas na borda das células e realizam a migração, dissociam a matriz extracelular e decodificam informações extracelulares ("atividade sensorial”).

Figura 12.5. Mecanismo da filopodia das células iniciadoras de brotamento. VEGF-A liga-se ao seu receptor na célula da extremidade, que é ativo e induz expressão de DLL4, que se liga ao receptor Notch-1 da célula-eixo vizinha. Modificado de: Carmeliet P, Jain R K. Molecular mechanisms and clinical aplications of angiogenesis. Nature 2011; 7347:298-307. 
A estabilização dos vasos necessita do recrutamento de pericitos, células musculares lisas e da deposição de MEC. Os principais fatores responsáveis pela maturação dos vasos são ANG1 e PDGF, que participam do recrutamento das células murais e TGF- $\beta$, que induz aumento da produção de MEC e estabiliza os vasos.

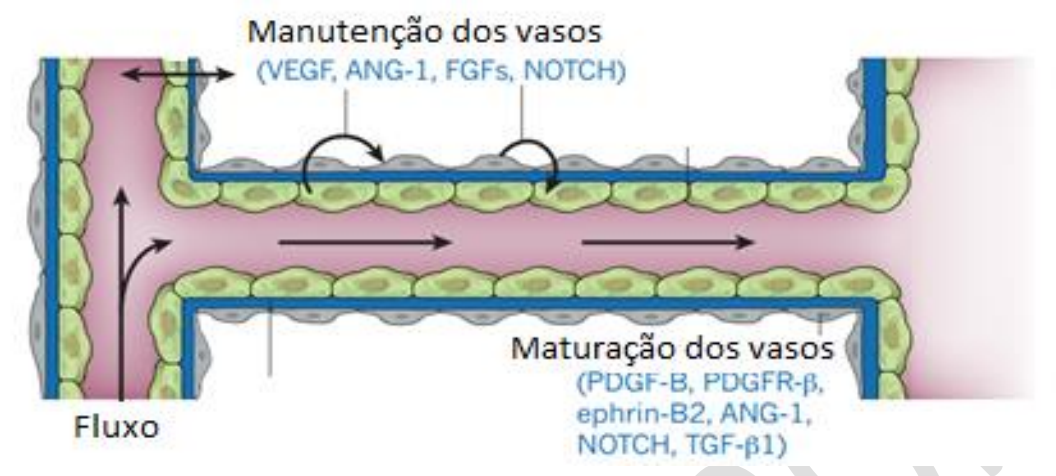

\section{ESTROMA COMO INDUTOR DE ANGIOGÊNESE}

O estroma é composto pela MEC e células de suporte (células não tumorais) como fibroblastos e pericitos, essa matriz e as células do estroma são essenciais na modulação da angiogênese.

A angiogênese intensifica-se quando as células tumorais se tornam invasivas e penetram no tecido, entrando em contato direto com células do estroma, como as células dos vasos e os fibroblastos próximos ao tumor.

No microambiente, as células tumorais produzem fatores que estimulam a proliferação delas próprias e das células do estroma. $\mathrm{O}$ estroma também produz fatores mitóticos para células tumorais e células do estroma.

As células tumorais atuam sobre o estroma, ao produzirem enormes quantidades de fatores de crescimento, entre estes o fator de crescimento derivado de plaqueta (PDGF), poderoso mitógeno, que estimula o fenômeno de proliferação das células do estroma, conhecido como estromalização. Este fator tem um papel fundamental também em atrair pericitos e células musculares lisas, conhecidas como células murais que complementam os vasos inicialmente formados por células endoteliais e tornam esses vasos maduros, fenômeno denominado como arteriogênese.

Além do PDGF, outro fator liberado é o fator de crescimento transformante beta (TGF- $\beta$ ), que atrai os CAFs, e os induz a produzir MMPs, que remodelam a MEC. As MMPs,
Figura 12.6. Maturação do vaso após o fenômeno de brotamento. Modificado de: Carmeliet P, Jain R K. Molecular mechanisms and clinical aplications of angiogenesis. Nature 2011; 7347:298-307.
O tumor apresenta estroma desmoplásico, onde as células do estroma podem modificar seu genótipo para sobreviver ao estresse fisiológico do novo ambiente criado pelo tumor.

Estromalização: fenômeno de ampliação das células e das estruturas do estroma, geralmente estimulada pelo fator PDGF.

Os vasos sanguíneos normais ou tumorais possuem células endoteliais e células murais (células musculares e pericitos).

\section{USO EXCLUSIVO}

III CURSO EM ONCOLOGIA MOLECULAR

(INSTITUTO DO CÂNCER DO ESTADO DE SÃO PAULO / FACULDADE DE MEDICINA DA UNIVERSIDADE DE SÃO PAULO)

Figuras modificadas somente para uso individual, não pertencem aos autores www.cursooncologia.com.br 
degradam a matriz extracelular, permitindo a remodelagem da estrutura do tumor, abrindo espaço para o crescimento do tumor, entrada de células do estroma e de vasos funcionais e essa degradação também libera uma grande quantidade de fatores de crescimento que foram sequestrados e inativados por essa matriz e que agora estão livres apara agir, como o fator básico de crescimento de fibroblastos (bFGF), fator de crescimento transformante (TGF- $\beta 1)$, PDGF, Interferon gama (INF- $\gamma$ ), VEGF e muitos outros fatores de células epiteliais.

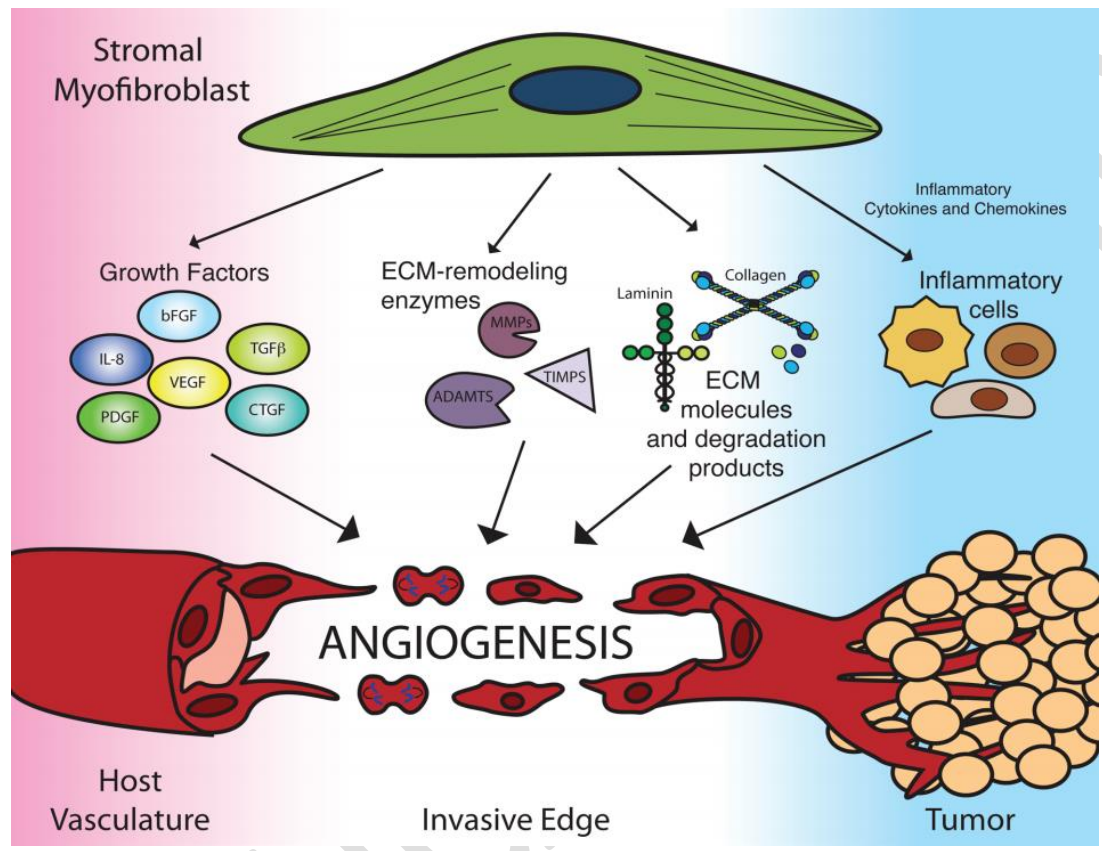

Os fibroblastos associados ao tumor (CAFs) presentes no estroma, secretam ainda mitógenos como o fator de crescimento de fibroblastos (FGFs), que estimula a proliferação de células epiteliais. Outro fator liberado pela inflamação do tumor, o TGF- $\beta$ estimula estes fibroblastos a se diferenciarem em miofibroblastos, que auxiliam na tumorigênese via angiogênese por liberarem o fator derivado de estroma 1 (SDF-1) e o ligante de receptor de quimiocina 12 (CXCL12) que são usadas para atrair e recrutar células precursoras endoteliais circulantes (PECs), o fator de crescimento VEGF também produzido por estes miofibroblastos ajuda a induzir as PECs a se diferenciarem em células endoteliais para formarem a nova vasculatura tumoral. A invasibilidade do tumor atua concomitantemente com o aumento da angiogênese tumoral, demostrando que o contato entre as células tumorais e não tumorais é um fator importante para a evolução do tumor.
Figura 12.7. Miofibroblastos modulando a angiogênese. Os fibroblastos associadsos ao tumor liberam diferentes fatores próangiogenicos, que ativam diretamente a angiogênese, como remodelam a MEC e recrutam células inflamatórias. Modificado de: Vong S, Kalluri R. The role of stromal myofibroblast and extracellular matrix in tumor angiogenesis. Genes Cancer 2011;12:1139-45.

Fibroblastos associados ao tumor (CAFs): fibroblastos, que apresentam características prótumorais, podendo participar tanto da iniciação, quanto da progressão do câncer.

PECs, células precursoras endoteliais circulantes: são células provenientes da medula óssea. 


\section{SISTEMA IMUNE COMO INDUTOR DE ANGIOGÊNESE}

A inflamação no ambiente tumoral é um evento que pode estimular a estromalização e indução da angiogênese tumoral dependente e independente do enriquecimento do estroma por outros fatores.

No sítio tumoral inflamado, plaquetas sanguíneas se agregam e liberam grânulos contendo PDGF e TGF- $\beta$. Como mencionado anteriormente, PDGF é um potente mitógeno de células do estroma, enquanto TGF- $\beta$ atrai fibroblastos e induz estas células a liberarem MMPs, que remodelam a matriz local abrindo espaço para a entrada de novas células e vasos sanguíneos. A dissociação da matriz libera inúmeros fatores de crescimento contidos nessa matriz que agora se tornam solúveis e ativos. Fatores vasoativos liberados pelo sítio da inflamação aumentam a permeabilidade de vasos sanguíneos próximos, levando a uma maior chance de desprendimento e disseminação de metástases.

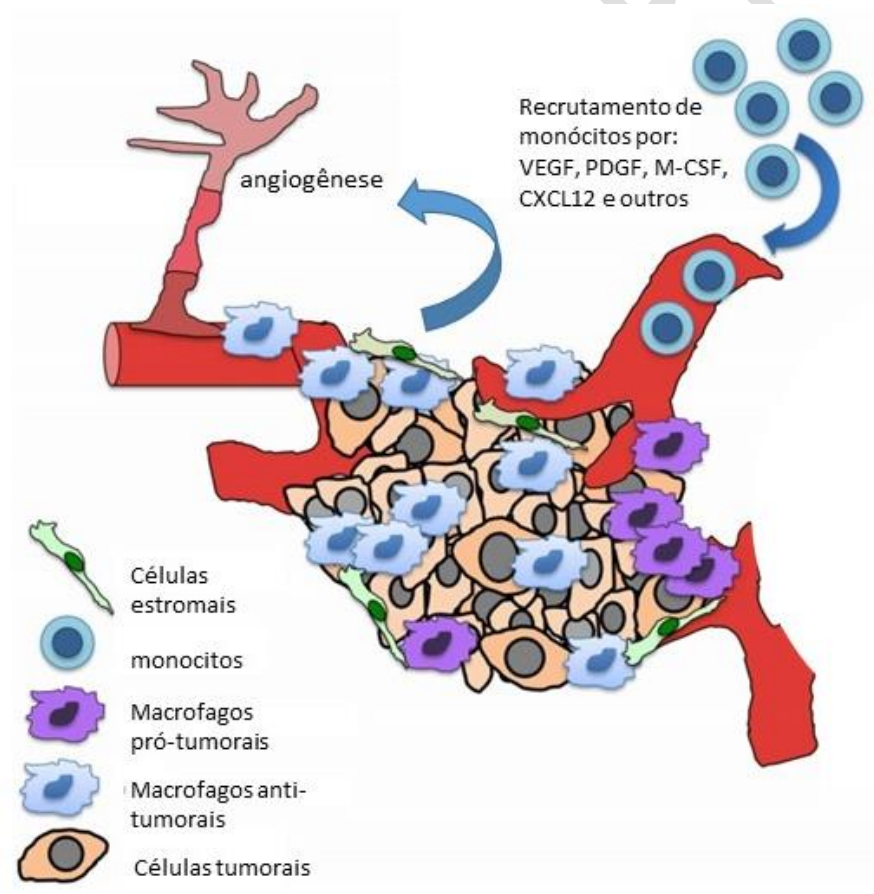

Alguns fatores pró-angiogenicos são capazes de atrair células do sistema imune. $\mathrm{O}$ fator quimiotático 1 (MCP-1) produzido no microambiente tumoral inflamado é capaz de atrair monócitos, estas células são estimuladas por VEGF e o fator estimulador de colônia 1 (CSF-1) e diferenciam-se em macrófagos associados ao tumor (TAMs). Foi observado em tumores uma correlação direta entre a quantidade de MCP-1,
Metástase: disseminação da célula tumoral para um sítio distante.

Figura 12.8. Macrófagos no microambiente tumoral. Monócitos são recrutados para o sítio tumoral e induzem a liberação de fatores pró-angiogênicos. Modificado de: Owen JL, Mohamadzadeh M. Macrophages and chemokines as mediators of angiogenesis. Front Physiol 2013; 2012.00159 .

Macrófagos associados ao tumor (TAMs): macrófagos encontrados no infiltrado leucocitário, podendo ter atividade anti e pró-tumoral. 
TAMs e o nível de angiogênese (medida pela densidade de vasos tumorais), sugerindo que os macrófagos associados ao tumor têm um papel importante na tumorigênese via angiogênese tumoral e que estás células induzem aumento no nível de vascularização. Essa correlação é de grande importância clínica, de modo que a alta densidade de macrófagos e a densa rede de vascularização no tumor são indicativos de um mal prognóstico para o paciente. Macrófagos associados ao tumor produzem: EGF, VEGF, IL-8 e MMPs. Em alguns carcinomas, a principal fonte de MMPs que degradam a matriz e abrem espaço para o crescimento tumoral e aumento da vasculatura vem dos TAMs.

Além dos monócitos, os neutrófilos também podem ser recrutados para o microambiente tumoral por fatores quimiotáticos liberados pelas células tumorais e pelo estroma. Os tumores apresentam uma grande quantidade de neutrófilos e seu número é aumentado em tumores invasivos. A IL-8 é o fator quimiotático mais conhecido, é conhecido por ser superexpresso no microambiente tumoral e atrair os neutrófilos circulantes. Outros fatores conhecidos por atrair essas células são as interleucinas 1,3,5,6 e citocinas inflamatórias. No sítio tumoral os neutrófilos passam a produzir fatores próangiogênicos, como VEGFs, FGFs, MMP-9 e a proteína oncostatina $\mathrm{M}$, conhecida por estimular células tumorais a liberar fatores de crescimento. Além disso a interação de neutrófilos com moléculas de adesão de células endoteliais (ICAM-1) também estimulam a angiogênese pela indução de proliferação das células endoteliais.

Assim os fatores de crescimento liberados por plaquetas, a degradação da matriz extracelular e a liberação de fatores quimiotáticos para células do sistema imune, acabam atraindo monócitos, macrófagos, neutrófilos, eosinófilos, mastócitos e linfócitos, que limpam o sítio da lesão e juntos liberam fatores mitogênicos, FGFs, VEGF entre outros que estimulam células endoteliais da vizinhança a construírem novos capilares.

\section{LINFANGIOGÊNESE}

Os vasos linfáticos são essenciais para manter a homeostasia de fluidos no tecido e o tráfego de células do sistema imune. A função desses vasos é formar um sistema de "esgoto" para o tecido, onde os ductos linfáticos drenam os fluidos dos interstícios entre as células e levam esse fluido para a circulação venosa, esse sistema também permite que células apresentadoras de antígeno do sistema imune transportem antígenos para os nódulos linfáticos, onde a resposta imune é iniciada.
Moléculas de adesão de células endoteliais: pertencente à família das imunoglobulina, participam de resposta inflamatória, e da sinalização intracelular.

Vasos linfáticos: participam do transporte da linfa dos tecidos, sendo essencial para a remoção de fluidos do espaço intersticial. 
Os vasos sanguíneos tumorais apresentam significativo vazamento de fluidos para os espaços parenquimatosos do tumor, devido a mal formação estrutural dos vasos intratumorais. O crescimento da massa tumoral exerce pressão nos ductos linfáticos, causando seu colapso em algumas áreas, já os capilares sanguíneos possuem uma maior capacidade de resistir a essa pressão devido à sua pressão hidrostática interna, ausente nos vasos linfáticos.

Em adultos a linfangiogênese é ativada em processos de reparo, respostas inflamatórias e metástase tumoral. A formação de vasos linfáticos opera por mecanismos similares ao dos vasos sanguíneos.

No desenvolvimento tumoral, os vasos linfáticos são importantes reguladores do balanço entre os fluidos do microambiente tumoral. Esses vasos também são usados para disseminação de metástases pelo organismo, tanto através de vasos linfáticos pré-existentes, como pela formação de novos vasos através de linfangiogenese induzida pelo tumor. O sistema linfático do tumor é construído por células endoteliais originárias da mesma população de células tronco embrionárias que originam os vasos e capilares sanguíneos.

Os fatores VEGF-C e VEGF-D secretados por tumores estimulam a linfangiogênese além de estimular a angiogênse. $\mathrm{O}$ VEGF-C é o principal fator modulador da vasculatura linfonodal, que interage com VEGFR-3 presente principalmente nos vasos linfáticos, embora também esteja presente nos vasos sanguíneos, sua principal função esta relacionada com a linfangiogênese. $\mathrm{O}$ uso de inibidores da via de VEGFR-3 inibe significantemente a disseminação metastática linfonodal.

Os macrófagos também atuam sobre a linfangiogênese, uma vez que o uso de inibidores de Fator de estimulação de colônia de macrófagos (M-CSF) inibe tanto a angiogênese como a linfangiogênese. As células do estroma também participam da linfoangiogênese tanto por produzirem VEGF-C e VEGF-D.
Fator de estimulação de colônia de macrófagos (M-CSF): citocina, que regula a diferenciação de células hematopoiéticas em macrófagos. 


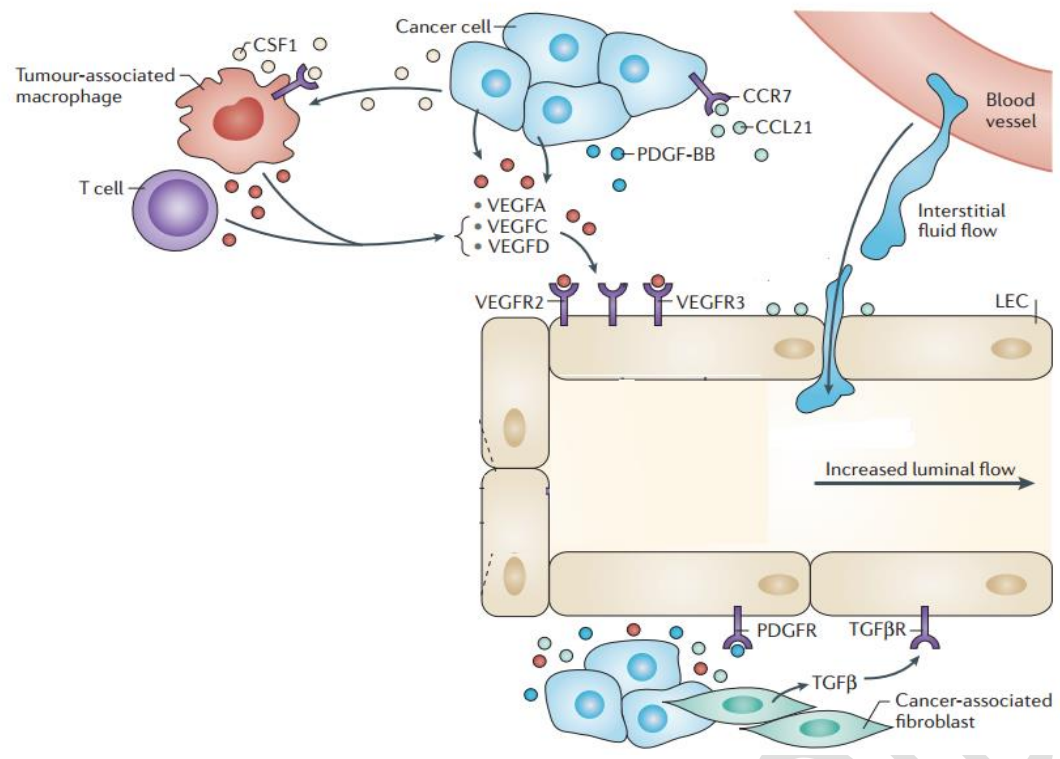

Figura 12.9. Bases da linfangiogênese. Os vasos linfáticos apresentam receptores de VEGFR2, VEGFR-3 e PDGFR, que podem ser ativos por fatores próangiogênicos como VEGF-C e PDGF, que induzem a linfoangiogênese. Modificado de: Stacker SA, Williams SP, Karnezis T, Shayan R, Fox SB, Achen MG. Lymphangiogenesis and lymphatic vessel remodeling in cancer. Nat Rev Cancer 2014;3:159-72.

\section{CARACTERÍSTICAS DOS VASOS TUMORAIS}

Os capilares de tumores sólidos ou adjacentes ao tumor, apresentam uma estrutura diferenciada, não organizada, com diâmetro variando em até 3 vezes maior que os capilares comuns dos tecidos do corpo. Essa estrutura diferenciada é dada por vasos tortuosos e colapsados, que circulam de volta para o mesmo vaso e ainda terminam em bolsas sem saída. As paredes dos vasos tumorais podem ser até 10 vezes mais permeáveis que os vasos normais, permitindo constantes vazamentos e disseminação de metástases. Essa característica é devida à produção desregulada dos fatores de crescimento, que são responsáveis por iniciar o crescimento dos capilares, esta superprodução de fatores pró-angiogênicos atrai e estimula as células endoteliais a se dividirem e recrutarem pericitos e células da musculatura lisa próprias de capilares, permitindo que esses vasos recém-formados se tornem maduros, porém desorganizados. 


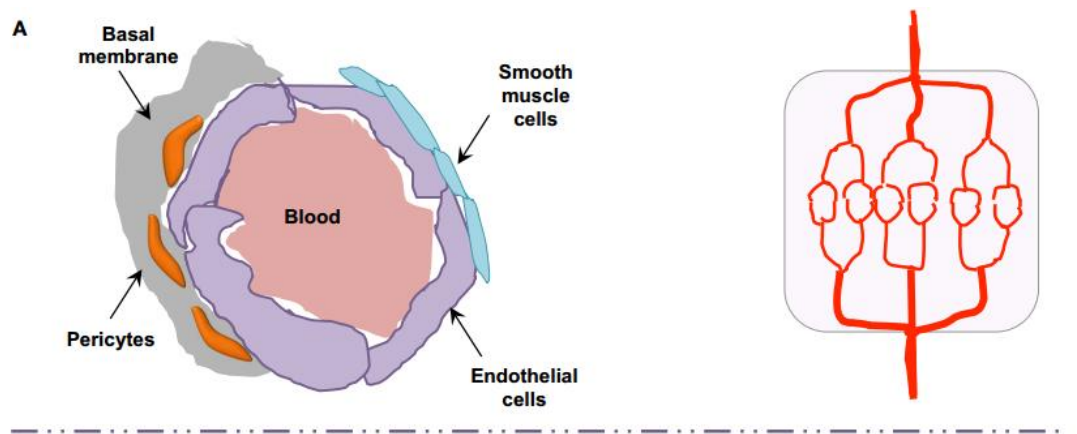

Figura 12.10. Comparação entre a estrutura do vaso normal e tumoral. Vasos tumorais apresentam-se tortuosos, com uma membrana basal frouxa e irregular. Azzi S, Hebda JK, Gavard J. Vascular permeability drug delivery in cancers. Front Oncol 2013;2013:3-211.
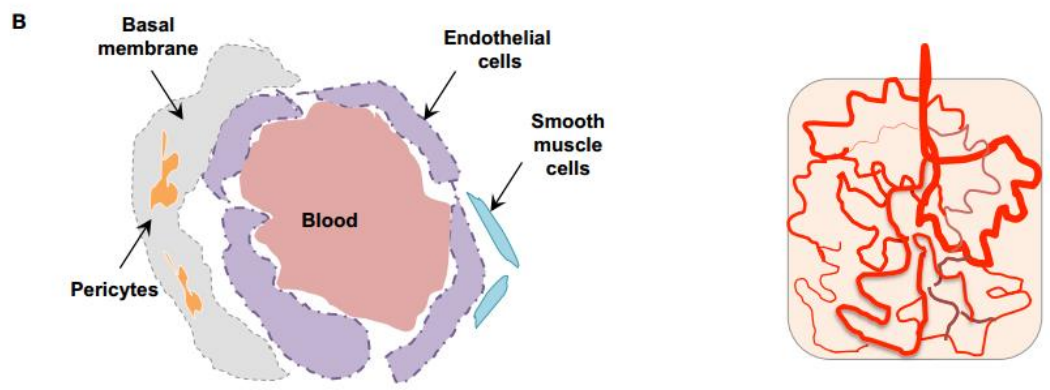

\section{METÁSTASE ENVOLVIDA NA ANGIOGÊNESE}

Além dos benefícios pró-tumorais da angiogênese, como suporte para o crescimento populacional devido a formação de uma rede de distribuição de nutrientes, oxigenação e metabolitos, essa nova rede de vascularização tem implicação no semeio de células tumorais da vascularização intratumoral para o sistema. A angiogênese promove metástase pela disseminação de células tumorais que desprenderam do tumor primário e penetraram na circulação, devido à criação de novos capilares tumorais altamente permeáveis. Esses capilares novos possuem membrana basal fina e frouxas junções celulares que disseminam as células tumorais para a circulação do indivíduo. Além disso, a linfangiogênese também favorece a disseminação metastática.

\section{MIMETISMO DE VASCULARIZAÇÃO}

Analise da expressão gênica de células provenientes de tumores altamente agressivos, indicou que essas células apresentam alta expressão de genes associados à células não tumorais com o fenótipos de células endoteliais, fibroblastos, células hematopoiéticas e outros tipos celulares, diferente de células de tumores fracamente metastáticos. Essas descobertas indicam que essas células tumorais revertem seu fenótipo para um tipo próximo ao embrionário. Muitas características do fenótipo embrionário são interessantes para a tumorigênese, como o recrutamento e formação de uma rede vascular, construída por vasculogênese.

Em 1999 foi publicado o primeiro trabalho sobre mimetismo de vascularização em ensaios in vivo e in vitro. Esse 
fenômeno é observado em células tumorais altamente metastáticas, que passam a expressar genes de células endoteliais e produzem matriz extracelular especifica de células endoteliais e acabam por apresentar uma rica vasculogênia, formada pelas próprias células tumorais.

Essa rede de vascularização mimética das células do tumor funciona como uma rede de condução de fluidos intratumorais. Esse mimetismo envolve várias moléculas de sinalização que estão envolvidas na vasculogênese embrionária, como as VE-caderinas, fosfatidilinositol 3-quinase (PI3K), quinases de adesão focal, metaloproteinases de matriz (MMPs) e laminina 5. Foi observado que essas redes similares a vasos formam voltas e arcos em volta das células tumorais e podem ser chamadas de "Canais Vasculares", podendo apresentar em seu interior até mesmo eritrócitos e plasma. Pesquisas atuais com melanoma mostraram o fenômeno de anastomose (quando dois vasos se fundem) entre os vasos tumorais endoteliais e os canais vasculares de mimetismo.

Os vasos miméticos têm função de perfusão de fluidos e funcionam independente e/ou simultâneo com os vasos tumorais endoteliais do tumor. Essa característica de mimetismo mostra o envolvimento da desregulação do fenótipo tumor-especifico e na transdiferenciação de tumores agressivos em outros fenótipos, como os de células endoteliais. Apesar desses estudos em mimetismo de vascularização serem recentes, eles começam a elucidar a plasticidade das células tumorais na angiogênese tumoral.

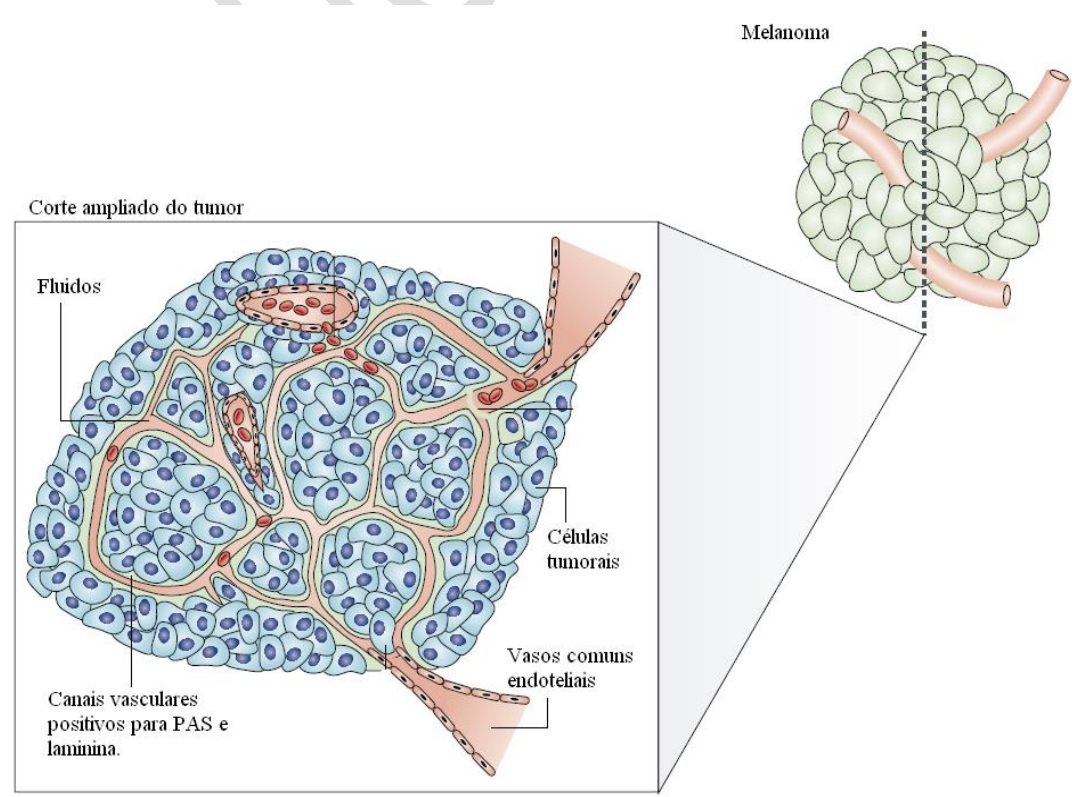

Fosfatidilinositol 3-quinase: envolvido na transdução de sinal, proliferação, diferenciação $e$ sobrevivência celular.

Lamininas: $\quad$ glicoproteínas componentes da MEC participam de atracamento, migração $e$ organização celular.

Anastomose: reconexão de duas vias, que haviam se separado.

Figura 12.11. Mecanismo geral do mimetismo de vascularização identificado pela marcação positiva por ácido periódico de Schiff (PAS) e laminina . Na figura é esquematizado um vaso tumoral irrigando o tumor e dentro do tumor, canais vasculomiméticos, como originalmente identificado usando-se colorações para glicoproteínas de membrana basal (PAS ou imunorreatividade para laminina). Modificado de : Hendrix M J, Seftor E A, Hess A R, Seftor R E. Vasculogenic mimicry and tumor cell plasticity: lessons from melanoma. Nat Rev Cancer 2003; 6:411-21. 
Ensaios clínicos mostram um mau prognostico para indivíduos com tumores portadores de mimetismo de vascularização. Esse fenótipo de mimetismo também é observado em outros tipos tumorais como câncer de mama, próstata, ovários e alguns sarcomas.

\section{TRATAMENTOS ANTI-ANGIOGÊNICOS}

Depois que Judah Folkman publicou em 1971 a hipótese de que o crescimento tumoral é dependente da angiogênese, muitos esforços foram realizados para identificar e produzir novas terapias com efeitos diretos na vasculatura tumoral, todos esses esforços tiveram como objetivo bloquear o crescimento tumoral, ou estrangular o tumor pela destruição dos vasos. Seus esforços permitiram o desenvolvimento da linha de tratamento antiangiogênico.

As células tumorais apresentam instabilidade genômica, e heterogeneidade, assim é frequente o desenvolvimento de resistência aos agentes quimioterápicos usuais voltados às células tumorais, que proliferam descontroladamente. Terapias antiangiogênicas atuam sobre células vasculares e fornecem um alvo de tratamento alternativo. As células da vasculatura (células endoteliais, pericitos e musculares lisas) são geneticamente normais, devido a esse fator, as drogas antiangiogênicas podem ter um efeito mais intenso e prolongado em destruir os vasos e assim causar um colapso na oxigenação, entrega de nutrientes e desestabilizar a estrutura do tumor causando um efeito antitumoral mais eficiente.

O desenvolvimento de vasos pela angiogênese necessita da cooperação de vários fatores de crescimento, receptores de membrana, inibidores de crescimento, tipos celulares e certas condições para ocorrer. $\mathrm{O}$ entendimento desses processos angiogênicos possibilitou a identificação de alguns alvos terapêuticos dirigidos para a inibição angiogênese tumoral e consequente retardo no crescimento do tumor. Alguns desses alvos são utilizados nas terapias anti-câncer.

Considerando que a massa tumoral não pode crescer mais que $2 \mathrm{~mm}^{3}$ sem o aporte de vasos sanguíneos, o tratamento antiangiogênico representa uma estratégia altamente eficiente para impedir a progressão tumoral.

Novos tratamentos anticâncer e anti-angiogênicos estão em desenvolvimento para agir de acordo com a assinatura molecular expressa pelas células tumorais e células do microambiente tumoral (células endoteliais, musculares, pericitos, fibroblastos, células imunes, entre outras). Na clínica, estratégias anti-angiogênicas normalmente se encontram combinadas com quimioterápicos tradicionais voltados contra as células tumorais, atuando assim em diferentes frentes para obter uma eficácia anti-tumoral maior. 
Outra vantagem do uso da terapia anti-angiogênica, é apresentar reduzidos efeitos adversos, quando comparados com os quimioterápicos tradicionais, pois em adultos o processo de angiogênese não é comum, com poucas exceções.

Os agentes anti-angiogênicos podem atuar como inibidores de fatores de crescimento endoteliais, inibidores da transdução de sinais de células endoteliais, inibidores da proliferação e sobrevivência endotelial, inibidores de MMPs, entre outras estratégias.

Terapias direcionadas para a vasculatura do tumor utilizam proteínas como angiostatina e endostatina, por serem biologicamente ativas, apenas para as células endoteliais, esses tratamentos mostraram resultados modestos e altos custos para realização. Os interferons $\alpha$ e $\beta$ são fortes supressores da síntese de fatores de crescimento como bFGF e IL-8.

$\mathrm{O}$ uso de anticorpos monoclonais como tratamento antiangiogênico adjuvante de quimioterapia para tumores começou a ser avaliado na década de 90 e hoje representa uma grande promessa para tratar alguns tipos de câncer. A maioria dos alvos anti-angiogênicos testados falharam em testes pré-clinicos e clínicos. As terapias-alvo para as isoformas de VEGF e seus receptores VEGFRs foram os poucos que funcionaram, contudo outros alvos angiogênicos estão sendo estudados como os inibidores de ANGs.

Avastin (Bevacizumab) foi o primeiro anticorpo monoclonal recombinante humanizado, com efeito antiangiogênico aprovado pelo FDA. Avastin (Bevacizumab) tem função de neutralizar o fator de crescimento VEGF-A; e, foi aprovado em fevereiro de 2004 para uso como tratamento coadjuvante de quimioterapia do câncer colorretal metastático. Quando foi usado em conjunto com quimioterapia, aumentou a sobrevida dos pacientes de 2 a 4 meses. O tratamento com Bevacizumab bloqueou o crescimento de tumores primários e metástases em camundongos; já em humanos apresentou efeito fraco, isso mostra a dificuldade da pesquisa oncológica para desenvolver tratamentos em humanos. Outros abordagens para neutralização de VEGF foram desenvolvidas: Zaltrap (aflibercept, domínio solúvel do receptor de VEGF) e os anticorpos Cyramza (ramucirumab), Lucentis (Ranibizumab).

Pequenas moléculas também são utilizadas para inibir os receptores tirosina quinase envolvidos na Angiogênese. Inibidores de tirosina quinases (TKIs) para multi-alvos, que bloqueiam vias de fatores de crescimento como os VEGFs também foram aprovados como Nexavar (Sorafenib), Stutent (Sunitinib) entre outras. Os efeitos colaterais dos inibidores de VEGF e do seu receptor são os mesmos, mal estar, erupções cutâneas, reações cutâneas nas mãos e nos pés, mielosupressão e hipertensão. Terapias antiangiogênicas combinadas com quimioterápicos ou terapias alvo-dirigidas têm sido testadas em

\begin{abstract}
Anticorpos monoclonais (mAbs): anticorpos produzidos a partir de linfócitos $B$, por exemplo fusionados a células de mieloma (levando à formação de hibridomas), que são ulteriormente humanizados. Tem a propriedade de reconhecer antígenos específicos e podem induzir uma resposta imune ou neutralizar o antígeno, como no caso de anticorpos antiangiogênicos.
\end{abstract}


centenas de protocolos clínicos registrados no National Institutes of Health (clinicaltrials.gov) e ilustram a necessidade de se alvejar simultaneamente mais de uma característica da massa tumoral para se ganhar eficiência naqueles casos de manejo mais difícil. 


\section{RESUMO}

O fenômeno de angiogênese tumoral é específico para cada tipo de tumor e confere uma importante característica prótumoral que na sua ausência impossibilita o tumor de crescer e se disseminar para o corpo. A formação de novos vasos tumorais realiza-se por eventos múltiplos, incluindo relações entre as células tumorais e não tumorais, produção exacerbada de fatores angiogênicos das células tumorais e do microambiente e também é influenciada pela vinda de células inflamatórias e células tronco da medula que funcionam como fábricas de fatores angiogênicos. Todos esses eventos simultâneos coordenam o brotamento de células endoteliais da margem do tumor a migrarem em direção ao tumor, formando novos vasos desorganizados que perfundem a massa tumoral e formam uma nova rede de vascularização específica, com função de nutrição, trocas gasosas e porta de entrada e saída para o sistema imune e metástases. A possibilidade de destruir os vasos ou mesmo estagnar seu crescimento tem funcionado como objetivo das terapias anti-angiogênicas, atualmente com utilização de anticorpos monoclonais ou mesmo proteínas recombinantes com alvos moleculares específicos no desenvolvimento e manutenção dos vasos tumorais. 
TERAPIAS ANTI-VEGF: MUITO ALÉM DA ANTI-ANGIOGÊNESE

A ideia lançada por Folkman e posteriormente posta à prova com várias abordagens que neutralizam de uma maneira ou de outra a sinalização dependente de VEGF chama a atenção por sua aparente lógica. Nada mais apropriado na estratégia da guerra contra o câncer do que sitiar o inimigo, cortando-lhe o acesso a nutrientes, inibindo a formação de vasos, críticos para o desenvolvimento do tumor. Muito provavelmente haverá sim um componente antiangiogênico nas terapias anti-VEGF. Contudo, VEGF é uma citocina extremamente pleiotrópica vale dizer que, quando neutralizamos sua atividade, não estamos somente neutralizando a formação de vasos novos, mas várias outras funções da citocina: indução de permeabilidade vascular, manutenção de estado indiferenciado de células dendríticas, funcionalidade de pericitos, para citar funções mais relacionadas ao microambiente tumoral.

O exemplo da terapia anti-VEGF é um excelente exemplo de que terapias combinadas, com alvos distintos da célula tumoral propriamente dita, são um caminho possível e promissor para a terapia contra tumores. A interpretação dos resultados obtidos, porém, deverá ir além da sedutora ideia de Folkman. O efeito observado, não em monoterapia, mas em terapia combinada com quimioterápicos, poderia ser atribuído a uma melhor entrega dos medicamentos à massa tumoral na vigência do tratamento com antiVEGF. Flutuações da permeabilidade vascular devido a uma situação de normalização da vasculatura tumoral poderiam, em parte, ser responsáveis aos efeitos observados.

De qualquer maneira, em algumas situações a terapia anti-VEGF é eficiente. Estudar sistematicamente aquelas condições onde os tumores são refratários a esta abordagem terapêutica, abrindo-se o
leque de possibilidades de interpretação da terapia para além da antiangiogênese poderá ser útil para se propor terapias inovadoras, cujo alvo seja o microambiente tumoral.

\section{TUMORES...}

Ainda, a análise detida dos casos que respondem à terapia, comparando-os com os que não respondem, tem trazido interessantes propostas de marcadores clínicos ou biomarcadores, cuja avaliação trará impacto no manejo dos pacientes com câncer.
Roger Chammas

Faculdade de Medicina da

Universidade de São Paulo/Instituto do Câncer do Estado de São Paulo 


\section{PARA SABER MAIS}

\section{BIBLIOGRAFIA GERAL}

Adams RH, Alitalo K. Molecular regulation of angiogenesis and lymphangiogenesis. Nat Rev Mol Cell Biol 2007;6:464-78.

Al-Husein B, Abdalla M, Trepte M, Deremer DL, Somanath PR. Antiangiogenic therapy for cancer: an update. Curr Oncol Rep 2012;12:1095-111.

Azzi S, Hebda JK, Gavard J. Vascular permeability drug delivery in cancers. Front Oncol 2013;2013:3-211.

Bergers G, Benjamim LE. Tumorigenesis and the angiogenic switch. Nat Rev Cancer 2003;6:40110

Carmeliet P and Jain R K. Angiogenesis in cancer and other diseases. Nature 2000; 407,249-257.

Carmeliet P, Jain R K. Molecular mechanisms and clinical aplications of angiogenesis. Nature 2011; 7347:298-307.

Carmeliet P. Angiogenesis in healthand disease. Nat Med2003;9:653-660.

Ferrara N, Kerbel RS. Angiogenesis as a therapeutictar- get. Nature2005;438:967-974.

Folkman J, Shing Y. Angiogenesis. J BiolChem 1992; 267:10931-10934.

Folkman J. Angiogenesis: an organizing principle for drug discovery? Nat Rev Drug Discov. 2007;4:273-86.

Hendrix M J, Seftor E A, Hess A R, Seftor R E. Vasculogenic mimicry and tumor cell plasticity: lessons from melanoma. Nat Ver Cancer 2003; 6:411-21.

Kumar V, Abbas AK, Fausto N, Aster JC. Patologia: Bases patológicas das doenças. Elsevier 2010:99-106.

Leyva-Illades D, McMillin M, Quinn M, DeMorrow S. Cholangiocarcinoma pathogenesis: Role of the tumor microenvironment. Transl Gastrointest Cancer 2012;1:71-80.
Owen JL, Mohamadzadeh M. Macrophages and chemokines as mediators of angiogenesis. Front Physiol 2013;2012.00159.

Rundhaug JE. Matrix metalloproteinases and angiogenesis. J Cell Mol Med 2005;2:267-285.

Stacker SA, Williams SP, Karnezis T, Shayan R, Fox SB, Achen MG. Lymphangiogenesis and lymphatic vessel remodeling in cancer. Nat Rev Cancer 2014;3:159-72.

Tammela T, Alitalo K. Lymphangiogeneses: Molecular mechanisms and future promise. Cell 2010;4:460-79.

Thomlinson RH, Gray LH. The histological structure of some human lung cancers and the possible implicattions for radiotherapy. $\mathrm{Br} \mathrm{J}$ Cancer 1955;4:539-49.

Thurston G, Noguera-Troise I, Yancopoulos GD. The Delta paradox: DLL4 blockade leads to more tumourves- selsbutlesstumourgrowth. Nat RevCancer2007;7:327- 331.

Tung JJ, Tattersall IW, Kitajewki J. Tips, stalks, tubes: notch-mediated cell fate determination and mechanisms of tubulogenesis during angiogenesis. Cold Spring Harb Perspect Med 2012;2:a006601

Vong S, Kalluri R. The role of stromal myofibroblast and extracellular matrix in tumor angiogenesis. Genes Cancer 2011;12:1139-45.

Weinberg, R. A Biologia do Câncer. Massachusetts: Artmed 2008:13.

Weis S, Cheresh DA. Tumor angiogenesis: molecular pathways and therapeutic targets. Nat Med 2011; 11: 1359-70. 


\section{ANEXO 5}

MANUSCRITO SUBMETIDO A REVISTA BMC CANCER 
BMC Cancer

\section{Distinct roles of direct transduction versus exposure to the tumor secretome on murine endothelial cells after melanoma gene therapy with interferon- $\beta$ and p19Arf \\ --Manuscript Draft--}

\begin{tabular}{|c|c|c|}
\hline \multicolumn{3}{|l|}{ Manuscript Number: } \\
\hline Full Title: & \multicolumn{2}{|c|}{$\begin{array}{l}\text { Distinct roles of direct transduction versus exposure to the tumor secretome on murine } \\
\text { endothelial cells after melanoma gene therapy with interferon- } \beta \text { and p19Arf }\end{array}$} \\
\hline Article Type: & \multicolumn{2}{|l|}{ Research article } \\
\hline Section/Category: & \multicolumn{2}{|l|}{ Cell and molecular biology } \\
\hline Funding Information: & $\begin{array}{l}\text { Fundação de Amparo à Pesquisa do } \\
\text { Estado de São Paulo } \\
\text { (13/25167-5) }\end{array}$ & Dr. Bryan E. Strauss \\
\hline Abstract: & \multicolumn{2}{|c|}{$\begin{array}{l}\text { Background: Tumor vasculature plays a central role in cancer progression, making it } \\
\text { an attractive therapeutic target since inhibition of angiogenesis has the potential to } \\
\text { slow tumor growth and inhibit metastasis. Here we explore the anti-angiogenic } \\
\text { potential of our melanoma gene therapy approach. We have previously shown that } \\
\text { combined interferon- } \beta \text { and p19Arf gene transfer reduces tumor progression by } \\
\text { inducing tumor cell apoptosis and an anti-tumor immune response. However, these } \\
\text { proteins have also been described as modulators of the tumor vasculature. In this } \\
\text { study, we explore the impact of INF } \beta \text { and p19Arf gene transfer on endothelial cells. } \\
\text { Methods: The AdRGD-PG adenoviral vectors encoding IFN } \beta \text { or p19Arf were used to } \\
\text { transduce tEnd (mouse endothelial cells). Alternatively, B16 (mouse melanoma cells) } \\
\text { were transduced and co-cultured with tEnd or used to produce conditioned medium. } \\
\text { The treated cells were subjected to tests of angiogenic potential, proliferation, viability, } \\
\text { cell death and gene expression. } \\
\text { Results: Gene transfer of p19Arf inhibits tEnd proliferation, tube formation, migration } \\
\text { and induces increased expression of genes related to the p53 cell death pathway. The } \\
\text { vector encoding IFN } \beta \text { alone had no significant impact upon transduction of tEnd. } \\
\text { Alternatively, tEnd cells were co-cultured with B16 cells that were previously } \\
\text { transduced with our adenoviral vectors or tEnd was cultivated in conditioned medium } \\
\text { derived from the transduced B16 cells. In either case, transduction of B16 cells with the } \\
\text { IFN } \beta \text { vector, whether alone or in combination with p19Arf, resulted in endothelial cell } \\
\text { death. } \\
\text { Conclusion: In this work, we have shown that inhibition of endothelial cells can be } \\
\text { performed directly by transduction with a vector encoding } 19 A r f \text { or when tEnd cells are } \\
\text { exposed to the secretome produce by tumor cells transduced with the IFN } \beta \text { virus. In } \\
\text { either case, our melanoma gene therapy strategy produces desirable, negative effects } \\
\text { on endothelial cells, possibly correlating with anti-angiogenic activity. }\end{array}$} \\
\hline Corresponding Author: & \multicolumn{2}{|c|}{$\begin{array}{l}\text { Bryan E. Strauss, PhD } \\
\text { Cancer Instititue of Sao Paulo, University of Sao Paulo School of Medicine } \\
\text { Sao Paulo, SP BRAZIL }\end{array}$} \\
\hline \multicolumn{3}{|l|}{$\begin{array}{l}\text { Corresponding Author Secondary } \\
\text { Information: }\end{array}$} \\
\hline Corresponding Author's Institution: & \multicolumn{2}{|c|}{ Cancer Instititue of Sao Paulo, University of Sao Paulo School of Medicine } \\
\hline \multicolumn{3}{|l|}{$\begin{array}{l}\text { Corresponding Author's Secondary } \\
\text { Institution: }\end{array}$} \\
\hline First Author: & \multicolumn{2}{|l|}{ Igor de Luna Vieira } \\
\hline \multicolumn{3}{|l|}{ First Author Secondary Information: } \\
\hline \multirow[t]{4}{*}{ Order of Authors: } & \multicolumn{2}{|l|}{ Igor de Luna Vieira } \\
\hline & \multicolumn{2}{|l|}{ Rodrigo Esaki Tamura, PhD } \\
\hline & \multicolumn{2}{|l|}{ Aline Hunger Ribeiro, MSc. } \\
\hline & \multicolumn{2}{|l|}{ Bryan E. Strauss, PhD } \\
\hline
\end{tabular}


Order of Authors Secondary Information:

Opposed Reviewers:

Powered by Editorial Manager ${ }^{\circledR}$ and ProduXion Manager ${ }^{\circledR}$ from Aries Systems Corporation 
São Paulo, Brazil, February 3, 2016

Editorial Board, BMC Cancer

Dear Dr. Sirs,

We respectfully submit the manuscript 'Distinct roles of direct transduction versus exposure to the tumor secretome on murine endothelial cells after melanoma gene therapy with interferon- $\beta$ and p19Arf' for consideration for publication in BMC Cancer. We believe that this work will be of interest to readers of BMC Cancer since it details significant advances in the development of a melanoma gene therapy approach and its impact on endothelial cells.

In this manuscript we present the application of our recombinant adenoviral vector where transgene expression is controlled by p53 in a model of murine melanoma. In this study, the p53-responsive vector was employed to deliver two different cDNAs, p19Arf and interferon-beta, with the hope of inhibiting angiogenic funcitons of a mouse endothelial cell line. We show for the first time that our approach induces two distinct outcomes, one when the endothelial cells were transduced and another when they were exposed to the factor produced by treated melanoma cells. In either approach, we show evidence that our melanoma gene therapy strategy also offers a distinct anti-angiogenic potential. We feel that this work will be of interest to the readers of BMC Cancer since we detail a variety of assays which show the advantages of our approach.

All authors have read the manuscript and approve of its submission to BMC Cancer. We declare that we have no financial conflicts of interest. In addition, this work has not been published elsewhere and is not under consideration by any other journal.

The figures have been prepared as high quality JPG files. If there are any concerns about quality, use of color or layout, we will be glad to provide figures that meet the demands of the journal.

Thank you so much for your consideration and we will be happy to facilitate this process in any way we can.

Sincerely,

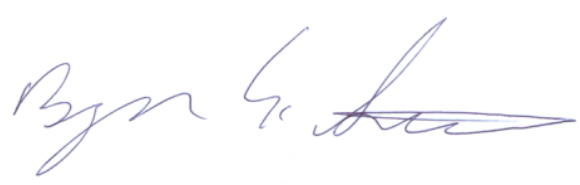

Bryan E. Strauss, $\mathrm{PhD}$

Cancer Institute of Sao Paulo

University of Sao Paulo School of Medicine

bstrauss@usp.br

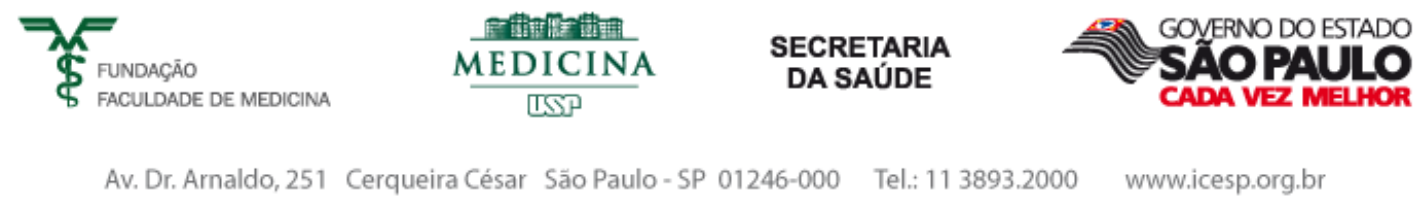




\section{Distinct roles of direct transduction versus exposure to the tumor secretome on murine endothelial cells after melanoma gene therapy with interferon- $\beta$ and p19Arf}

Igor de Luna Vieira ${ }^{1}$, Rodrigo Esaki Tamura ${ }^{1}$, Aline Hunger Ribeiro ${ }^{1}$ and Bryan E. Strauss ${ }^{1, *}$

1-Viral Vector Laboratory, Center for Translational Investigation in Oncology/LIM24, Cancer Institute of São Paulo, School of Medicine, University of São Paulo.

*Corresponding author: Bryan E. Strauss, $\mathrm{PhD}$

Viral Vector Laboratory

Center for Translational Investigation in Oncology

Cancer Institute of São Paulo

Av. Dr. Arnaldo, 251, 8th Floor

Cerqueira César-São Paulo, SP, Brazil

CEP: 01246-000

Tel: +55(11)3893-3554

bstrauss@usp.br, bryan.strauss@hc.fm.usp.br

Keywords: Angiogenesis, Endothelial cells, Melanoma, Interferon beta, p19Arf 


\section{ABSTRACT}

Background: Tumor vasculature plays a central role in cancer progression, making it an attractive therapeutic target since inhibition of angiogenesis has the potential to slow tumor growth and inhibit metastasis. Here we explore the anti-angiogenic potential of our melanoma gene therapy approach. We have previously shown that combined interferon- $\beta$ and p19Arf gene transfer reduces tumor progression by inducing tumor cell apoptosis and an anti-tumor immune response. However, these proteins have also been described as modulators of the tumor vasculature. In this study, we explore the impact of INF $\beta$ and p19Arf gene transfer on endothelial cells.

Methods: The AdRGD-PG adenoviral vectors encoding IFN $\beta$ or p19Arf were used to transduce tEnd (mouse endothelial cells). Alternatively, B16 (mouse melanoma cells) were transduced and co-cultured with tEnd or used to produce conditioned medium. The treated cells were subjected to tests of angiogenic potential, proliferation, viability, cell death and gene expression.

Results: Gene transfer of p19Arf inhibits tEnd proliferation, tube formation, migration and induces increased expression of genes related to the p53 cell death pathway. The vector encoding IFN $\beta$ alone had no significant impact upon transduction of tEnd. Alternatively, tEnd cells were co-cultured with B16 cells that were previously transduced with our adenoviral vectors or tEnd was cultivated in conditioned medium derived from the transduced B16 cells. In either case, transduction of B16 cells with the IFN $\beta$ vector, whether alone or in combination with p19Arf, resulted in endothelial cell death.

Conclusion: In this work, we have shown that inhibition of endothelial cells can be performed directly by transduction with a vector encoding 19Arf or when tEnd cells are exposed to the secretome produce by tumor cells transduced with the IFN $\beta$ virus. In 
either case, our melanoma gene therapy strategy produces desirable, negative effects on endothelial cells, possibly correlating with anti-angiogenic activity.

\section{Background}

Melanoma is the most aggressive and deadliest form of skin cancer [1]. The etiology of melanoma involves environmental, phenotypic and genetic phenomena [2, 3] and the tumor itself is composed of transformed melanocytes and a variety of stromal cells which provide support and even promote progression [4]. Particularly important are the tumor blood vessels which control the supply of nutrients [5], maintain blood flow and regulate leukocyte trafficking, including recruitment of myeloid cells needed to promote angiogenesis [6]. The blood vessels are composed of smooth muscle cells, pericytes and endothelial cells which are especially active in the amplification process of cancer growth and spread [7]. Because the endothelial cells play such a critical role, we have chosen these as the subject of our study aimed at further developing a cancer gene therapy approach.

We have chosen interferon $\beta$ (IFN $\beta$ ) and p19Arf for cancer gene therapy due to their multiple anti-neoplastic activities. IFN $\beta$ is a cytokine well known for its role in anti-viral defense, immune modulation and induction of cell death [8,9]. The p19Arf tumor suppressor gene (p19Arf in murines, p14Arf in humans) is best known for its role in preventing the interaction of p53 with MDM2, resulting in p53 activation and accumulation [10-12]. In fact, critical interaction between the IFN and p53/Arf pathways has been shown to aid anti-viral defense and cell killing [13, 14]. 
In addition, IFN $\beta$ and p19Arf each offer anti-angiogenic functions. IFN $\beta$ acts on endothelial cells, reducing the production of pro-angiogenic factors and inducing cell death [15]. Angiogenesis is modulated by p19Arf through p53 dependent and independent mechanisms [16-18]. Whether used individually or in tandem, we expect that the introduction of IFN $\beta$ and p19Arf would have an impact on the tumor vasculature.

Melanomas typically retain p53 in the wild type form [19], possibly serving as a molecular target for treatment. For this, we have developed adenoviral vectors where high-level transgene expression is controlled by p53 in an Ad5 construct [20] or Ad5 with RGD modification (AHR, manuscript submitted). We have used these vectors to transfer the p19Arf and interferon- $\beta$ genes, resulting in enhanced melanoma cell death in vitro and in vivo [21], induction of a protective immune response in models of melanoma and lung carcinoma [22] (BES, manuscript submitted) as well as a strong bystander effect between treated and untreated melanoma cells (AHR, manuscript submitted). However, our previous studies did not include evaluation of the tumor vasculature upon treatment with our gene therapy approach.

Here, we show that AdRGD-PG (non-replicating Ad5 with RDG tripeptide modification and transgene expression under the control of p53) expressing p19Arf inhibits migration, tube formation and cell proliferation and also induces apoptosis upon transduction of the tEnd murine endothelial cell line. Exposure of tEnd to the factors produced by B16 cells after their transduction with the adenoviral vector encoding IFN $\beta$ revealed a paracrine effect that resulted in endothelial cell death. Collectively these data indicate that our vectors have a desirable, negative impact on endothelial cell activity consistent with the inhibition of angiogenesis upon melanoma gene therapy. 


\section{Methods}

\section{$\underline{\text { Cell lines }}$}

The murine melanoma cell lines B16F10 (B16) and TM1 were kindly provided by Dr. Roger Chammas, Faculdade de Medicina, Universidade de São Paulo, SP, Brazil; tEnd (murine endothelial cell line) was kindly provided by Dr. Cristina Maria Fernandes, Instituto Butanta, SP, Brazil; HEK293A (adenovirus-transformed human embryonic kidney) cell line was obtained commercially (Invitrogen Life Technologies, Carlsbad, CA, USA). The B16, TM1 and tEnd cell lines were maintained in RPMI (Life Technologies) and HEK293A line was maintained in DMEM (Invitrogen Life Technologies) plus 5\% FBS (Life Technologies) and 1\% Antibiotic-Antimytotic (Invitrogen Life Technologies), maintained at $37{ }^{\circ} \mathrm{C}$ in a humidified atmosphere with $5 \% \mathrm{CO}_{2}$

\section{Production and transduction of adenoviral vectors}

The AdRGD-PG vectors (non-replicating Ad5 with RGD fiber modification and transgene expression under the control of a p53-responsive promoter, termed PG) encoding GFP (enhanced green fluorescent protein), p19Arf or murine IFN $\beta$ will be described in detail elsewhere (AHR, manuscript submitted). AdRGD-CMVLacZ [23] was kindly provided by Dr. Hiroyuki Mizuguchi (Osaka University, Japan). The adenoviruses were produced in the HEK293A cell line and purified by an iodixanol ultracentrifugation as described previously [24]. The viral stocks were titrated using the Adeno-X Rapid Titer Kit (Clontech, Mountain View, CA USA). For transduction, the multiplicity of infection (MOI) indicated in each assay was applied in DMEM or RPMI 
medium with $5 \%$ FBS and $1 \%$ Antibiotic-Antimytotic and maintained at $37^{\circ} \mathrm{C}$ at $5 \%$ $\mathrm{CO}_{2}$ atmosphere.

\section{$\underline{X-G a l ~ s t a i n i n g}$}

tEnd cells were plated in 6 well dishes, $1 \times 10^{5}$ cells/well, transduced with the LacZ vector at a MOI of 200 and incubated for 24 hours. After this period the cells were fixed with $2 \%$ paraformaldehyde $/ 0.2 \%$ glutaraldehyde for 5 minutes at $4{ }^{\circ} \mathrm{C}$. For $\mathrm{X}$-Gal staining, the cells were first washed with $0.1 \mathrm{M}$ phosphate buffer $(\mathrm{pH}$ 7.3) supplemented with $2 \mathrm{mM} \mathrm{MgCl}$ and then immersed in X-Gal staining buffer $(0.1 \mathrm{M}$ phosphate buffer, $\mathrm{pH}$ 7.3, supplemented with $2 \mathrm{mM} \mathrm{MgCl}_{2}, 5 \mathrm{mM}$ potassium ferrocyanide, $5 \mathrm{mM}$ potassium ferricyanide and $1 \mathrm{mg} / \mathrm{ml}$ of $\mathrm{X}-\mathrm{Gal}$ ) and incubated at $37^{\circ} \mathrm{C}$ for 16 hours.

\section{Flow cytometric detection of GFP positive cells}

B16, TM1 and tEnd cells were seeded in 6 well dishes, $5 \times 10^{4}$ cells/well, transduced with GFP at a MOI of 200 and incubated for 24 hours. After harvesting the cells, they were analyzed for GFP expression by flow cytometry (Attune, Invitrogen Life Technologies). The percentage of GFP positive cells was determined by the Attune software.

\section{$\underline{\text { Immunofluorescence detection of p19Arf }}$}

B16 and tEnd cells were seeded onto $13 \mathrm{~mm}$ round glass coverslips, $5 \times 10^{4}$ cells/well, in 24 well dishes, transduced 24 hours later with a MOI of 200 of adenoviral vectors and fixed with methanol 24 hours later. Then, cells were blocked with bovine serum 
albumin (Sigma-Aldrich, St. Louis, MO, EUA), probed with a rabbit polyclonal antibody for p19Arf (AB-1, Cal-Biochem, San Diego, CA, USA) followed by an Alexa488 labeled anti-rabbit secondary antibody (Molecular Probes, Eugene, OR, USA). Hoechst 33258, $20 \mu \mathrm{g} / \mathrm{ml}$ (Molecular Probes) was used for nuclear staining. Cells were visualized by fluorescent EVOS microscopy (Invitrogen Life Technologies).

\section{Enzyme-linked immunosorbent assay for detection of IFN $\beta$}

Fifty-thousand B16 or tEnd cells were transduced with the adenoviral vectors at a MOI of 200 and after incubation for 24 hours the supernatants were collected. Detection of IFN $\beta$ was made by ELISA, following procedures of PBL Biomedical ${ }^{\mathrm{Tm}}$ manual and absorbance $(450 \mathrm{~nm})$ was determined with Victor $^{\mathrm{Tm}}$ plate reader (Perkin-Elmer, Waltham, MA, USA).

\section{Wound healing assay}

tEnd cells were seeded, $1 \times 10^{4}$ cells in 12 well plates, and 24 hours later a pipette tip was used to create a wound in the confluent monolayer cells and transduction was performed (MOI 200) in the presence of Mitomycin C (20 $\mu \mathrm{g} / \mathrm{mL})$. Photomicrographs were taken at 0 hours (time of wounding and transduction) and 24 hours later. The migration area was calculated using the Zeiss LSM Image Browser program. The calculations were performed as follows: $\left.\left(\mathrm{M}^{0}-\mathrm{M}^{24}\right) / \mathrm{M}^{0}\right)^{*} 100=\mathrm{X}$, where $\mathrm{M}^{0}$ is the average migration area at time $0, \mathrm{M}^{24}$ is the average migration area at time 24 hours and $\mathrm{X}$ is the resulting percentage. After calculating the rate of migration, data were normalized by the following formula: $\mathrm{T}^{\mathrm{T}} / \mathrm{C}^{\mathrm{T}} * 100=\mathrm{X}$, where $\mathrm{T}^{\mathrm{C}}$ is the percentage of 
the control group wound coverage, $\mathrm{T}^{\mathrm{T}}$ is the resulting percentage of the treated group and $\mathrm{X}$ is the resulting percentage standard for control.

\section{$\underline{\text { Tubologenesis assay }}$}

tEnd cells were previously transduced (MOI 200) and incubated for 6 hours. Then they were harvested, counted and $1 \times 10^{4}$ cells/well were seeded in 24-well plates containing basic Matrigel (BD Biosciences, San Jose, CA, USA). Photographs were taken 48 hours after seeding of the cells and the number of tubes was quantified. Tubes were defined as closed tubes formed by more than two cells.

\section{$\underline{\text { Clonogenic assay }}$}

The tEnd cells were transduced with the adenoviral vectors (MOI 200) and incubated for 6 hours. Then, cells were harvested, counted and $1 \times 10^{3}$ cells were seeded per 10 $\mathrm{cm}$ plate and incubated for 10 days. For the clonogenic assay with conditioned medium, 300 tEnd cells were seeded with conditioned medium in 6-well plates and incubated for 10 days. After incubation time, cells were fixed with 5\% acetic acid/95\% methanol solution and stained with Trypan Blue. Colonies were quantified manually.

\section{$\underline{\text { Cell viability assay }}$}

For the MTT assay, $1 \times 10^{3}$ cells/well, in quadruplicate, were plated in 96-well dishes. The next day, cells were transduced (MOI 200), then incubated for 48 hours before determination of cell viability. Plates were incubated with $25 \mu$ l of MTT solution (5 
$\mathrm{mg} / \mathrm{ml}$ in $1 \mathrm{x}$ PBS), $37{ }^{\circ} \mathrm{C}$ during 4 hours. The dish was then removed and the precipitate solubilized by the addition of $100 \mu$ lysis buffer (20\% SDS in $50 \%$ DMF/2\% acetic acid, $\mathrm{pH}$ adjusted to 4.7 ) before analysis using Victor $^{\mathrm{Tm}}$ plate reader (Perkin-Elmer, Waltham, MA, USA) at $570 \mathrm{~nm}$.

\section{$\underline{\text { Identification of hypodiploid and Annexin- } \mathrm{V} \text { positive cells }}$}

For both tests, $2 \times 10^{4}$ tEnd cells/well were seeded in 6 well plates, transduced the next day (MOI 200) and then incubated for 48 hours. Alternatively, for treatment with conditioned medium, cells were plated as above, but the following day received the indicated conditioned medium and then were incubated for 48 hours. Cells were then fixed with $70 \%$ ethanol and stained with P.I. for quantification of hypodiploid cells. For identification of Annexin-V-Alexa488 and P.I., fresh cells were labeled immediately after the 48 hour incubation period. In this case, the LacZ vector was used as a control. Both analyses were performed by flow cytometry and associated software (Attune, Invitrogen Life Technologies).

\section{Co-culture assay}

We first modified tEnd cells with the Lego-iT2 lentiviral vector (kindly provided by Kristoffer Rieken, University Medical Center Hamburg, Germany), which offers constitutive expression of the dTomato fluorescent protein, to generate the tEndTO cell line. tEnd cells, $1 \times 10^{4}$ in a $60 \mathrm{~mm}$ dish, were transduced with Lego-iT2 at a MOI of 1 in the presence of $8 \mu \mathrm{g} / \mathrm{mL}$ polybrene before replating in a $100 \mathrm{~mm}$ dish. Cellular clones were screened, identifying the highest level of dTomato fluorescene and 
repeating this process until a homogenous cell population, called tEndTO, was established. We next used $1 \times 10^{4}$ tEndTO cells co-cultured with $1 \times 10^{4}$ B16 cells previously transduced for 6 hours (MOI 300) and then washed to remove virus particles. The two types of cells were co-cultured for 72 hours. Photographs were taken (EVOS FL, Invitrogen Life Technologies) 24 and 72 hours after seeding. Quantification of each cell type was aided by use of the Image $\mathbf{J}$ program. Results from each time point in each independent experiment were normalized using the following formula: $\mathrm{N}_{T} / \mathrm{N}_{\mathrm{C}}=\mathrm{V}$, where $\mathrm{N}_{T}$ is the average number of treated cells/field, $\mathrm{N}_{C}$ is the average number of control cells/field and $\mathrm{V}$ is the resulting value.

\section{Production of conditioned medium}

To produce conditioned medium, $5 \times 10^{4}$ B16 cells were transduced (MOI 300) and incubated for 6 hours and then washed 4 times with 1x PBS to remove virus particles. Fresh culture medium was then added and cells incubated for 48 hours. Then, medium was collected, centrifuged to separate out cellular debris and stored at $-80{ }^{\circ} \mathrm{C}$. The conditioned medium derived from B16 cells was named mc-B16 (control not transduced), mc-B16-GFP (control transduced with GFP), mc-B16-IFN (transduced with IFN $\beta$ ), mc-p19-B16 (transduced with p19Arf), mc-B16-IFN+p19 (co-transduced with IFN $\beta$ and p19Arf).

\section{$\underline{\text { Reverse transcriptase-quantitative polymerase chain reaction (RT-qPCR) analysis }}$}

The tEnd cells were plated in 6 wells dishes, $5 \times 10^{4}$ cells/well, and transduced with the adenoviral vectors (MOI 200). After 24 hours, total RNA was isolated using Trizol 
(Invitrogen Life Technologies) following the fabricant's instructions. Concentration of RNA was measured by absorbance at $260 \mathrm{~nm}$. Quality of RNA was assessed by protein and salt concentration (absorbance $280 \mathrm{~nm}$ ) and by visualizing the $18 \mathrm{~S}$ and $28 \mathrm{~S}$ ribosomal RNA bands in a 1\% agarose gel. Primers (Additional file 1, Table S1) were designed and then analyzed using Primer-BLAST (http://www.ncbi.nlm.nih.gov/tools/primer-blast/). We used $\beta$-actin as the reference gene. Primer efficiency was assessed and confirmed to be nearly $100 \%$. Extracted RNA was reverse transcribed using random primers and MMLV reverse transcriptase (Invitrogen Life Technologies). Reaction conditions were 100 ng cDNA; 12.5 pmol each primer; $8 \mu \mathrm{L}$ of Syber Green PCR Master Mix (Invitrogen Life Technologies) in a final volume of $20 \mu \mathrm{L}$. Amplification was performed using denaturation at $95^{\circ} \mathrm{C}$ for 1 min and extension at $72^{\circ} \mathrm{C}$ for 1 min and samples were analyzed by the 7500 Fast Software, version 2.05 (Applied Biosytems/Invitrogen Life Technologies). The $2^{-\Delta \Delta \mathrm{Ct}}$ method was used for quantification and data is presented as fold-change in expression $\left(\log _{2}\right)$ as compared with tEnd transduced with the GFP vector.

\section{$\underline{\text { Statistical analysis }}$}

Data are expressed as the mean \pm SD from at least three experiments. Statistical analysis was carried out using analysis of variance (ANOVA) followed by Tukey's test, significant at a level of $p<0.05$. Analysis was performed by using GraphPad Prism 5.0. 


\section{Results}

\section{Validation of adenoviral vectors}

Expression of the GFP, LacZ, IFN $\beta$ and p19Arf transgenes upon transduction with the recombinant adenoviral vectors was analyzed by fluorescence microscopy, staining with X-Gal, Elisa or immunofluorescence, respectively (Additional file 2, Figure S1). These assays demonstrate reliable expression of the transgenes when tEnd (mouse immortalized endothelial cells) or B16 (mouse melanoma cells) were transduced with our AdRGD-PG vectors.

\section{tEnd cells are more efficiently transduced than B16 or TM1 melanoma cells}

After confirmation of strong transgene expression, we compared the transduction efficiency of endothelial and melanoma cells lines when using the GFP vector (MOI 50). The tEnd cells were transduced more efficiently than B16 or TM1 (Figure 1). These data indicate that in the context of the tumor microenvironment our RGD-modified vectors may transduce endothelial cells more efficiently than melanoma cells.

\section{p19Arf inhibits angiogenic characteristics of transduced tEnd cells}

We next transduced tEnd cells with our recombinant adenoviruses and analyzed indicators of angiogenic potential, specifically migration and tube formation. In the migration assay, the wound was formed and immediately followed by transduction and treatment with Mitomycin C (0h). The next day (24h), we observed significantly reduced migration when the tEnd cells had been transduced with the p19Arf vector alone (Figure 2A and $\mathbf{B}$ ). In the tubologenesis assay, cells were transduced with the vectors, incubated for 6 hours and then plated in wells containing Matrigel. After 48 
hours of incubation, the cells were photographed and the number of tubes formed was quantified. tEnd cells transduced with p19Arf alone or in combination with IFN $\beta$ showed significantly fewer tubes (Figure 2C and D).

\section{Tranduction of tEnd with p19Arf triggers cell death}

The reduction in angiogenic potential described above may be due, in part, to alterations in cell proliferation and viability. To test this possibility, tEnd cells were transduced with a MOI of 200 before colony formation, viability, cell cycle and apoptosis were evaluated. In the clonogenic and viability (MTT) assays, only combined p19Arf and IFN $\beta$ gene transfer significantly impacted tEnd cells, though a tendency was noted with individual p19Arf, but not IFN $\beta$, treatment (Figure 3A, B and C). Interestingly, p19Arf either alone or in combination with IFN $\beta$ strongly induced accumulation of hypodiploid (sub-G1) or Annexin-V positive cells (Figure 3D and E), indicating that p19Arf was sufficient to induce cell death by a mechanism consistent with an apoptosis. These assays suggest that p19Arf is the dominant factor for inducing tEnd cell death upon transduction.

Introduction of p19Arf in tEnd cells promotes expression of key genes in the p53 pathway

To deepen our understanding of the endothelial cell response to treatment with our adenoviral vectors, we sought changes in the expression of key genes in the p53 pathway after transduction (MOI 200) of tEnd cells. Total RNA was harvested 24 hours post-transduction, cDNA was produced by reverse transcription and gene expression was analyzed by qPCR. Figure 4 shows increased expression of p53 in response to treatment with both IFN $\beta$ and p19Arf. However, activation of MDM2, p21 and PUMA 
genes required only p19Arf and did not benefit from the presence of IFN $\beta$. These findings suggest that p19Arf, but not IFN $\beta$, is key for activating the p53 pathway when tEnd cells are transduced with our adenoviral vectors.

\section{Co-culture of tEnd cells with transduced B16 melanoma cells reveals critical role of} IFN $\beta$

Up to this point in our study, we have shown that direct transduction of tEnd cells with an adenoviral vector encoding p19Arf results in cell death, revealing a possible benefit of our melanoma gene therapy approach. We next examined whether the factors produced by the transduced tumor cells would have an impact on the endothelial cell line. For this, we used a co-culture assay since this is a relevant means of simulating the interaction of different cell types in the tumor microenvironment [25]. In order to differentiate the two cell lines on the same plate, we labeled tEnd cells with constitutive expression of the dTomato fluorescent protein, generating the tEndTO cell line. In this assay, B16 cells were transduced (MOI 300, 6 hours), washed, collected and $1 \times 10^{4}$ of these cells were plated together with an equal number of tEndTO cells and observed for up to 72 hours (Figure 5A). Interestingly, the tEndTO population was reduced in the presence of B16 cells treated with IFN $\beta$ vector, whether alone or in combination with p19Arf (Figure 5B). Consistent with our previous findings [21, 22] and (AHR, manuscript submitted), transduction of B16 cells inhibits their proliferation when one or both of the genes were applied (Figure 5C). This co-culture assay shows that the secretome produced by B16 cells upon transduction with an adenovirus encoding IFN $\beta$, but not p19Arf, can negatively impact the population of tEnd cells. 


\section{IFN及 induces tEnd cell death}

Next, we used the conditioned medium derived from B16 cells (cm-B16) transduced with the recombinant adenoviral vectors for the cultivation of tEnd cells and examined the impact of the tumor secretome on these endothelial cells. The clonogenic assays showed that tEnd cells treated with cm-B16-IFN or cm-B16-IFN+p19 significantly reduced the number of colonies formed (Figure 6A and $\mathbf{B}$ ). In the cell viability, cell cycle and apoptosis analyses, the tEnd cells were treated with conditioned medium for 48 hours and then the tests were performed. The three tests showed that conditioned medium from mc-B16-IFN and cm-B16-IFN+p19 decreased viability, increased the population of hypodiploid and Annexin-V labeled cells (Figure 6C, D and E, respectively). Note that the use of p19Arf did not seem to influence these assays, suggesting a critical role for IFN $\beta$. These data suggest that the conditioned medium containing the secretome from B16 transduced with the vector encoding IFN $\beta$ induces tEnd cell death by a mechanism consistent with apoptosis. 


\section{Discussion}

This study used a model intended to highlight the response of endothelial cells to our combined IFN $\beta+$ p19Arf gene transfer approach for the treatment of melanoma. Here we employed our AdRGD-PG vectors, containing the RGD-modified fiber and where transgene expression is controlled by $\mathrm{p} 53$, in order to transduce endothelial cells directly and observed that p19Arf, but not IFN $\beta$, was essential for impeding the angiogenic potential of tEnd cells and for the induction of their death. Alternatively, the secretome produced by B16 melanoma cells upon transduction with the adenoviral vectors also led to the death of tEnd cells, however in this case IFN $\beta$ was essential for inducing this response. We suspect that this secretome may contain important factors in addition to IFN $\beta$ since direct transduction of tEnd with the vector encoding IFN $\beta$ had little impact. In either case, we postulate that our gene therapy approach would reduce tumor angiogenesis, either by direct or indirect signaling.

Adenoviral vectors have been widely used for cancer gene therapy due to their relative stability, efficient gene transfer in vivo and broad tropism in terms of cell type $[26,27]$. Even so, transduction by serotype 5 adenovirus (Ad5) relies on the expression of a specific cellular receptor (coxsackie-adenovirus receptor, CAR), thus tropism may be considered limited if the target cell does not express CAR. Extensive efforts have been made to overcome CAR dependence and to direct adenoviral transduction to specific cell types [28-30]. A well-known approach for altering tropism involves the introduction of the RGD tripeptide in the adenovirus fiber protein, thus alleviating dependence on CAR and directing the virus to interact with cells expressing integrins [23].

Since melanomas typically retain wild type $\mathrm{p} 53$, we propose that this may serve as a molecular target of treatment. To this end, we have developed a series of viral 
vector platforms, including retrovirus, adenovirus and adenoassociated virus, where transgene expression is under the control of p53 [20, 31, 32]. Using the AdPG vector (native Ad5 fiber), we showed that the combination of IFN $\beta+p 19 A r f$ is beneficial for killing B16 cells in vitro and in vivo [21] and plays an essential role in NK cell activation and inducing a protective immune response [22]. We then constructed the AdRGD-PG platform in order to improve viral tropism and have used these vectors to show the induction of immunogenic cell death in B16 (AHR, manuscript submitted) and for the stimulation of a protective immune response with critical participation of neutrophils in a mouse model of lung carcinoma (BES, manuscript submitted). These previous studies highlight the importance of the IFN $\beta+$ p19Arf combination for the induction of cell death and immune activation.

As presented here, we have identified novel aspects of our gene transfer approach. In agreement with our previous work, the vectors were shown to express high levels of the transgene. Strikingly, the tEnd cell line was much more efficiently transduced when compared with the melanoma tumor cell lines B16 and TM1. Though not studied directly, we hypothesize that this result may be due to the high amount of integrins present in endothelial cell membranes [25], thus favoring transduction with our recombinant adenoviral vectors bearing the RGD motif in the adenoviral fiber protein. Certainly, the importance of integrins and the RGD motif for endothelial cell biology [33, 34] and for the targeting of viral vectors [23, 30, 35] has been extensively explored. Though the AdRGD-PG approach was not specifically developed for targeting tumor vasculature, this may indeed prove to be a benefit when using this vector platform.

Angiogenic characteristics of endothelial cells, such as migration and tube formation, were inhibited by upon transduction of the tEnd cells with the p19Arf vector. 
In addition, cell death by a mechanism consistent with apoptosis was also observed in this scenario. Since the expression of critical factors in the p53 pathway was concomitantly increased, we infer that these genes contributed to the cellular response since p21 participates in cell cycle control [36] and PUMA induces apoptosis [37, 38]. Based on these results, we postulate that our gene therapy approach may indeed offer an anti-angiogenic benefit when endothelial cells are transduced with a vector encoding p19Arf. Certainly, further exploration is necessary to confirm this point in vivo. It has been shown that activation of the p53/Arf pathway can significantly decrease cell motility by repression of phosphoinositide 3-kinase and Rac1 activity and can induce senescence [39, 40], additional activities that would favor an approach involving transduction of both the tumor and its microenvironment.

As presented here, transduction of tEnd cells resulted in their death when the vector encoded p19Arf. We next investigated if transduction of the tumor cells would release factors that would then have an impact on the neighboring endothelial cells. Transduction of B16 cells with the IFN $\beta$ vector, but not p19Arf, indeed produced some factor(s) that impacted the endothelial cells in both the co-culture and conditioned medium assays. In fact, tEnd cells were killed when cultivated in the conditioned medium derived from B16 cell transduced with the IFN $\beta$ vector alone or in combination with p19Arf. Again, our melanoma gene therapy approach may indeed have the desired, negative impact on angiogenesis since the secrotome generated by the tumor cells treated with IFN $\beta$ was lethal for the endothelial cells.

Our study raises several interesting possibilities. First, our melanoma gene therapy approach depends on the cooperation of IFN $\beta$ with p19Arf. However, we did not see evidence of cooperation that may yield an anti-angiogenic effect, suggesting distinct mechanisms in B16 versus tEnd cells. Even so, the observations made here are 
potentially beneficial for tumor treatment. Second, we saw distinct activities when the endothelial cells were transduced as compared to their exposure to the factors released by the treated tumor cells. This too was not an expected finding, but still points to the anti-angiogenic potential of our approach. Finally, we demonstrated that IFN $\beta$ gene transfer did not impact tEnd cells upon transduction, but they were killed when exposed to factors released by transduced B16 cells. This is especially intriguing, suggesting that a factor other than IFN $\beta$ may have been responsible for this observation. Recall that transduced tEnd cells produced just as much IFN $\beta$ as B16 cells, yet the endothelial cells only responded to the tumor secretome generated after IFN $\beta$ gene transfer. Since IFN $\beta$ was present in both scenarios, we postulate that the latter involved additional factors, a point that will require extensive investigation in the future.

Based on examples from the literature, we would expect than IFN $\beta$ present in conditioned medium should have an impact on the exposed, cultured cells. That is to say, we would expect a paracrine or bystander effect mediated by IFN $\beta$. For example, conditioned medium from melanoma cells transfected with a plasmid encoding IFN $\beta$ showed a strong paracrine effect where conditioned medium was cytotoxic for nontransfected melanoma cells [41]. It has been shown that not only are the tumor cells targeted by a paracrine effect mediated by IFN $\beta$, but also other cells in the tumor microenvironment are affected, undergoing apoptosis and reducing angiogenesis due to IFN $\alpha / \beta$ activity [42]. Ex vivo gene transfer of IFN $\beta$ to bladder cancer cells delays growth of the tumor due to the induction of apoptosis of endothelial cells upon implantation in vivo [43] and IFN $\beta$ activates expression of genes related to decline in survival and proliferation [44]. In another study, systemic IFN $\beta$ produced by liver targeted AAV resulted in maturation of tumor vessels and improved blood flow, yet inhibited tumor growth by impeding further angiogenesis [45]. In fact, our own work 
has shown a significant bystander effect where presence of p19Arf sensitized B16 cells to the effects of neighboring B16 cells that had been transduced with the IFN $\beta$ vector (AHR, manuscript submitted). Certainly, further testing, especially in vivo studies, will be required to reveal the full impact of our melanoma gene therapy approach on the tumor microenvironment in general and angiogenesis in particular.

\section{Conclusion}

With this study we have taken the first steps to show that our gene therapy approach combining IFN $\beta$ and p19Arf may indeed impact endothelial cells. The use of an adenoviral vector containing the RGD tripeptide in the fiber protein yielded increased transduction efficiency for tEnd cells as compared to the melanoma cell lines, direct transduction with the vector encoding p19Arf or exposure to the tumor secretome produced after transduction with the vector encoding IFN $\beta$ both resulted in endothelial cell killing. Though much remains to be elucidated, the work presented here shows that our approach warrants further development and investigation. 


\title{
Additional files
}

File name: Additional file 1 Table S1

File format: PDF

Title: Table S1

Description: Sequence of oligonucleotides used for qPCR

File name: Additional file 2 Figure S1

File format: PDF

Title: Figure S1

Description: Validation of transgene expression in transduced cells.

\begin{abstract}
Abbreviations:
AAV: Adenoassociated virus

Ad5: Recombinant adenovirus, serotype 5, native fiber protein.

AdRGD-PG: Recombinant adenovirus, serotype 5, RGD-modified fiber protein, p53responsive promoter used to drive transgene expression.

Arf: Alternate reading frame (p19Arf in murines, p14ARF in humans) of the CDKN2a locus

MOI: Multiplicity of infection
\end{abstract}

\section{Competing interests}

None of the authors have any competing interests to declare. 


\section{Author's contributions}

ILV: Conceived and executed assays, analyzed data and wrote the manuscript.

RET: Aided with assays, data analysis and reviewed the manuscript.

AHR: Constructed and provided the adenoviral vectors, reviewed the manuscript.

BES: Conceived the study and assays, analyzed data and wrote the manuscript.

\section{Acknowledgements}

We thank Dr. Roger Chammas (Instituto do Câncer do Estado de São Paulo, SP, Brazil) for continued support and helpful discussions and Dr. Cristina Maria Fernandes (Instituto Butantã, SP, Brazil) for providing the endothelial cell line, an essential component of this and future endeavors. Funding: São Paulo Research Foundation, grant 13/25167-5 (BES) and fellowships 11/21256-8 (RET); 08/55963-0 and 11/106565 (AHR). 


\section{REFERENCES}

1. Siegel R, Ma J, Zou Z, Jemal A: Cancer statistics, 2014. CA Cancer J Clin 2014, 64(1):929.

2. Higgins HW, 2nd, Lee KC, Galan A, Leffell DJ: Melanoma in situ: Part I. Epidemiology, screening, and clinical features. J Am Acad Dermatol 2015, 73(2):181-190, quiz 191182.

3. Gandini S, Sera F, Cattaruzza MS, Pasquini P, Picconi O, Boyle P, Melchi CF: Metaanalysis of risk factors for cutaneous melanoma: II. Sun exposure. Eur J Cancer 2005, 41(1):45-60.

4. Villanueva J, Herlyn M: Melanoma and the tumor microenvironment. Curr Oncol Rep 2008, 10(5):439-446.

5. Dudley AC: Tumor endothelial cells. Cold Spring Harb Perspect Med 2012, 2(3):a006536.

6. Schmid MC, Varner JA: Myeloid cell trafficking and tumor angiogenesis. Cancer Lett 2007, 250(1):1-8.

7. Michiels C: Endothelial cell functions. J Cell Physiol 2003, 196(3):430-443.

8. Schoggins JW, Rice CM: Interferon-stimulated genes and their antiviral effector functions. Curr Opin Virol 2011, 1(6):519-525.

9. Chawla-Sarkar M, Lindner DJ, Liu YF, Williams BR, Sen GC, Silverman RH, Borden EC: Apoptosis and interferons: role of interferon-stimulated genes as mediators of apoptosis. Apoptosis 2003, 8(3):237-249.

10. Kamijo T, Weber JD, Zambetti G, Zindy F, Roussel MF, Sherr CJ: Functional and physical interactions of the ARF tumor suppressor with p53 and Mdm2. Proceedings of the National Academy of Sciences of the United States of America 1998, 95(14):8292-8297.

11. Zhang $Y$, Xiong $Y$, Yarbrough WG: ARF promotes MDM2 degradation and stabilizes p53: ARF-INK4a locus deletion impairs both the Rb and p53 tumor suppression pathways. Cell 1998, 92(6):725-734.

12. Milojkovic A, Hemmati PG, Muer A, Overkamp T, Chumduri C, Janicke RU, Gillissen B, Daniel PT: p14ARF induces apoptosis via an entirely caspase-3-dependent mitochondrial amplification loop. Int J Cancer 2013, 133(11):2551-2562.

13. Takaoka A, Hayakawa S, Yanai H, Stoiber D, Negishi H, Kikuchi H, Sasaki S, Imai K, Shibue $\mathrm{T}$, Honda $\mathrm{K}$ et al: Integration of interferon-alpha/beta signalling to p53 responses in tumour suppression and antiviral defence. Nature 2003, 424(6948):516523.

14. Sandoval R, Xue J, Pilkinton M, Salvi D, Kiyokawa H, Colamonici OR: Different requirements for the cytostatic and apoptotic effects of type I interferons. Induction of apoptosis requires ARF but not p53 in osteosarcoma cell lines. J Biol Chem 2004, 279(31):32275-32280.

15. Bracarda S, Eggermont AM, Samuelsson J: Redefining the role of interferon in the treatment of malignant diseases. Eur J Cancer 2010, 46(2):284-297.

16. Kawagishi H, Nakamura H, Maruyama M, Mizutani S, Sugimoto K, Takagi M, Sugimoto M: ARF suppresses tumor angiogenesis through translational control of VEGFA mRNA. Cancer Res 2010, 70(11):4749-4758.

17. Ulanet DB, Hanahan D: Loss of p19(Arf) facilitates the angiogenic switch and tumor initiation in a multi-stage cancer model via p53-dependent and independent mechanisms. PLoS One 2010, 5(8):e12454. 
18. Teodoro JG, Evans SK, Green MR: Inhibition of tumor angiogenesis by p53: a new role for the guardian of the genome. J Mol Med (Berl) 2007, 85(11):1175-1186.

19. Giglia-Mari G, Sarasin A: TP53 mutations in human skin cancers. Hum Mutat 2003, 21(3):217-228.

20. Bajgelman MC, Strauss BE: Development of an adenoviral vector with robust expression driven by p53. Virology 2008, 371(1):8-13.

21. Merkel CA, Medrano RF, Barauna VG, Strauss BE: Combined p19Arf and interferonbeta gene transfer enhances cell death of B16 melanoma in vitro and in vivo. Cancer Gene Ther 2013, 20(5):317-325.

22. Medrano RFV, Canani JPP, Ribeiro AH, Tomaz SL, Merkel CA, Costanzi-Strauss E, Strauss BE: Vaccination using melanoma cells treated with p19arf and interferonbeta gene transfer in a mouse model: A novel combination for cancer immunotherapy. Cancer Immunol Immunother 2016, In press.

23. Mizuguchi H, Koizumi N, Hosono T, Utoguchi N, Watanabe Y, Kay MA, Hayakawa T: A simplified system for constructing recombinant adenoviral vectors containing heterologous peptides in the HI loop of their fiber knob. Gene Ther 2001, 8(9):730735.

24. Peng HH, Wu S, Davis JJ, Wang L, Roth JA, Marini FC, 3rd, Fang B: A rapid and efficient method for purification of recombinant adenovirus with arginine-glycineaspartic acid-modified fibers. Anal Biochem 2006, 354(1):140-147.

25. Danhier F, Pourcelle V, Marchand-Brynaert J, Jerome C, Feron O, Preat V: Targeting of tumor endothelium by RGD-grafted PLGA-nanoparticles. Methods Enzymol 2012, 508:157-175.

26. Crystal RG: Adenovirus: the first effective in vivo gene delivery vector. Hum Gene Ther 2014, 25(1):3-11.

27. Kasala D, Choi JW, Kim SW, Yun CO: Utilizing adenovirus vectors for gene delivery in cancer. Expert Opin Drug Deliv 2014, 11(3):379-392.

28. Alonso-Padilla J, Papp T, Kajan GL, Benko M, Havenga M, Lemckert A, Harrach B, Baker AH: Development of Novel Adenoviral Vectors to Overcome Challenges Observed With HAdV-5-based Constructs. Mol Ther 2015.

29. Khare $R$, Chen $C Y$, Weaver EA, Barry MA: Advances and future challenges in adenoviral vector pharmacology and targeting. Curr Gene Ther 2011, 11(4):241-258.

30. Beatty MS, Curiel DT: Chapter two--Adenovirus strategies for tissue-specific targeting. Adv Cancer Res 2012, 115:39-67.

31. Bajgelman MC, Medrano RF, Carvalho AC, Strauss BE: AAVPG: A vigilant vector where transgene expression is induced by $\mathrm{p} 53$. Virology 2013, 447(1-2):166-171.

32. Strauss BE, Costanzi-Strauss E: pCLPG: a p53-driven retroviral system. Virology 2004, 321(2):165-172.

33. Dettin M, Zamuner A, Roso M, lucci G, Samouillan V, Danesin R, Modesti M, Conconi MT: Facile and selective covalent grafting of an RGD-peptide to electrospun scaffolds improves HUVEC adhesion. J Pept Sci 2015, 21(10):786-795.

34. Li J, Ding $M$, Fu $Q$, Tan $H$, Xie $X$, Zhong Y: A novel strategy to graft RGD peptide on biomaterials surfaces for endothelization of small-diamater vascular grafts and tissue engineering blood vessel. J Mater Sci Mater Med 2008, 19(7):2595-2603.

35. Pesonen S, Diaconu I, Cerullo V, Escutenaire $S$, Raki M, Kangasniemi L, Nokisalmi $P$, Dotti G, Guse K, Laasonen L et al: Integrin targeted oncolytic adenoviruses Ad5-D24RGD and Ad5-RGD-D24-GMCSF for treatment of patients with advanced chemotherapy refractory solid tumors. Int J Cancer 2012, 130(8):1937-1947.

36. el-Deiry WS, Tokino T, Velculescu VE, Levy DB, Parsons R, Trent JM, Lin D, Mercer WE, Kinzler KW, Vogelstein B: WAF1, a potential mediator of $\mathrm{p} 53$ tumor suppression. Cell 1993, 75(4):817-825. 
37. Nakano K, Vousden KH: PUMA, a novel proapoptotic gene, is induced by p53. Molecular Cell 2001, 7(3):683-694.

38. Chipuk JE, Bouchier-Hayes L, Kuwana T, Newmeyer DD, Green DR: PUMA couples the nuclear and cytoplasmic proapoptotic function of p53. Science 2005, 309(5741):17321735.

39. Guo F, Gao Y, Wang L, Zheng Y: p19Arf-p53 tumor suppressor pathway regulates cell motility by suppression of phosphoinositide 3-kinase and Rac1 GTPase activities. J Biol Chem 2003, 278(16):14414-14419.

40. Debidda M, Williams DA, Zheng Y: Rac1 GTPase regulates cell genomic stability and senescence. J Biol Chem 2006, 281(50):38519-38528.

41. Rossi UA, Gil-Cardeza ML, Villaverde MS, Finocchiaro LM, Glikin GC: Interferon-beta gene transfer induces a strong cytotoxic bystander effect on melanoma cells. Biomed Pharmacother 2015, 72:44-51.

42. Benedict WF, Tao Z, Kim CS, Zhang X, Zhou JH, Adam L, McConkey DJ, Papageorgiou A, Munsell M, Philopena J et al: Intravesical Ad-IFNalpha causes marked regression of human bladder cancer growing orthotopically in nude mice and overcomes resistance to IFN-alpha protein. Mol Ther 2004, 10(3):525-532.

43. Izawa JI, Sweeney P, Perrotte P, Kedar D, Dong Z, Slaton JW, Karashima T, Inoue K, Benedict WF, Dinney CP: Inhibition of tumorigenicity and metastasis of human bladder cancer growing in athymic mice by interferon-beta gene therapy results partially from various antiangiogenic effects including endothelial cell apoptosis. Clin Cancer Res 2002, 8(4):1258-1270.

44. Gomez D, Reich NC: Stimulation of primary human endothelial cell proliferation by IFN. J Immunol 2003, 170(11):5373-5381.

45. Dickson PV, Hamner JB, Streck CJ, Ng CY, McCarville MB, Calabrese C, Gilbertson RJ, Stewart CF, Wilson CM, Gaber MW et al: Continuous delivery of IFN-beta promotes sustained maturation of intratumoral vasculature. Mol Cancer Res 2007, 5(6):531542. 


\section{Figure legends}

Figure 1: Endothelial cells are more permissive to transduction than melanoma cell lines. tEnd, B16 and TM1 cells were transduced with the GFP vector (MOI 500) and the next day GFP-positive cells were detected by flow cytometry. Result represents the average and s.d. from three independent experiments. $* * p<0.01$; *** $p<0.001$, ANOVA followed by Tukey's multi-comparison post-test.

Figure 2: Analysis of angiogenic characteristics after transduction of endothelial cells. (A and B) A monolayer of tEnd cells was scratched with a pipette tip, transduced (MOI 200) and treated with Mitomycin C (anti-proliferative) at time 0 hour (0h). Photomicrographs (EVOS FL, 10x objective) were taken at 0h and again 24 hours later (24h). Wound closure (migration) rate normalized to the control condition (as described in Materials and Methods). (C and D) tEnd cells were transduced (MOI 200) and incubated for 6 hours before seeding on Matrigel and incubation for 48 hours when photomicrographs we taken (EVOS FL, 10x objective), manual counting yielded the number of tubes formed. Results represent the average and s.d. from three independent experiments. ${ }^{* *} \mathrm{p}<0.01$; ANOVA followed by Tukey's multi-comparison post-test.

Figure 3: Assessment of viability and cell death upon transduction of tEnd cells. (A and B) For this clonogenic assay, tEnd cells were transduced (MOI 200) and six hours later, $1 \times 10^{3}$ cells were seeded in $10 \mathrm{~cm}$ plates, incubated for 10 days, fixed and stained with Trypan Blue before manually counting clearly visible colonies. Plates were scanned (Multifunction Printer LaserJet, HP) to produce these images. (C) Viability assay where tEnd cells were transduced (MOI 200) and incubated for 48 hours before MTT solution was added and analyzed at $570 \mathrm{~nm}$. (D) tEnd cells were transduced (MOI 200), incubated for 48 hours, fixed with $70 \%$ ethanol and stained with P.I. before quantification of the hypodiploid cell population by flow cytometry. (E) For evaluation of cell death, tEnd cells were transduced (MOI 200) and incubated for 48 hours before staining with Annexin-V/Alexa488 and P.I. Results represent the average and s.d from three independent experiments. ${ }^{*} \mathrm{p}<0.05$; ${ }^{* * *} \mathrm{p}<0.001$; ANOVA followed by Tukey's multi-comparison post-test.

Figure 4: Transduction of tEnd with the adenoviral vectors impacts expression of key genes in the p53 pathway. Cells were transduced (MOI 200) with adenoviral vectors, incubated for 24 hours before RNA extraction and processing for RT-qPCR. We used $\beta$-actin as the reference gene. Results represent the average and s.d. from triplicate PCR reactions from three independent experiments. $* p<0.05 ; * * p<0.01$; ANOVA followed by Tukey's multi-comparison post-test.

Figure 5: Co-culture of tEndTO with previously transduced B16 cells. B16 cells were transduced (MOI 300), incubated for 6 hours, washed, collected and plated together with tEndTO cells at equal proportions. The co-culture was incubated for up to 
72 hours. (A) Fluorescence microscopy reveals the red tEndTO cells and the unmarked B16 cells (EVOS FL, 10x objective). Alterations in the cell populations were quantified by counting (B) marked tEndTO cells and (C) unmarked B16 cells at 72 hours. Quantification was performed using Image $\mathbf{J}$ software. Results were normalized to the control condition and represent the average and s.d. from three independent experiments. ${ }^{*} \mathrm{p}<0.05 ;{ }^{*} \mathrm{p}<0.01$; ANOVA followed by Tukey's multi-comparison posttest.

Figure 6: Conditioned medium derived from transduced B16 cells was used for the cultivation of tEnd cells. B16 was transduced (MOI 300) with the adenoviral vectors, incubated for 6 hours, washed and fresh medium was added. After incubation for 48 hours, the conditioned medium was collected and stored at $-80{ }^{\circ} \mathrm{C}$ before use. The conditioned medium was named according to the transgene: cm-B16 (non-transduced), mc-B16-GFP, mc-B16-IFN, mc-B16-p19 and mc-B16-IFN+p19. (A and B) For the clonogenic assay, 300 tEnd cells were seeded with conditioned medium in 6 well plates and incubated for 10 days. Then cells were fixed and stained. Plates were scanned to produce these images (Multifunction Printer LaserJet, HP) and clearly visible colonies were counted. (C) In this viability assay, tEnd cells were treated with conditioned medium for 48 hours before MTT solution was added and analyzed at $570 \mathrm{~nm}$. (D) The hypodiploid cell population was revealed after tEnd cells were cultivated in the presence of conditioned medium for 48 hours, fixation, staining with P.I. and then analysis by flow cytometry. (E) Apoptotic cells were assessed by flow cytometry after cultivation of tEnd cells in conditioned medium for 48 hours and staining with Annexin-V Alexa488/P.I. Results represent the average and s.d. from three independent experiments. ${ }^{*} \mathrm{p}<0.05$; ${ }^{*} \mathrm{p}<0.01$; ANOVA followed by Tukey's multi-comparison posttest. 


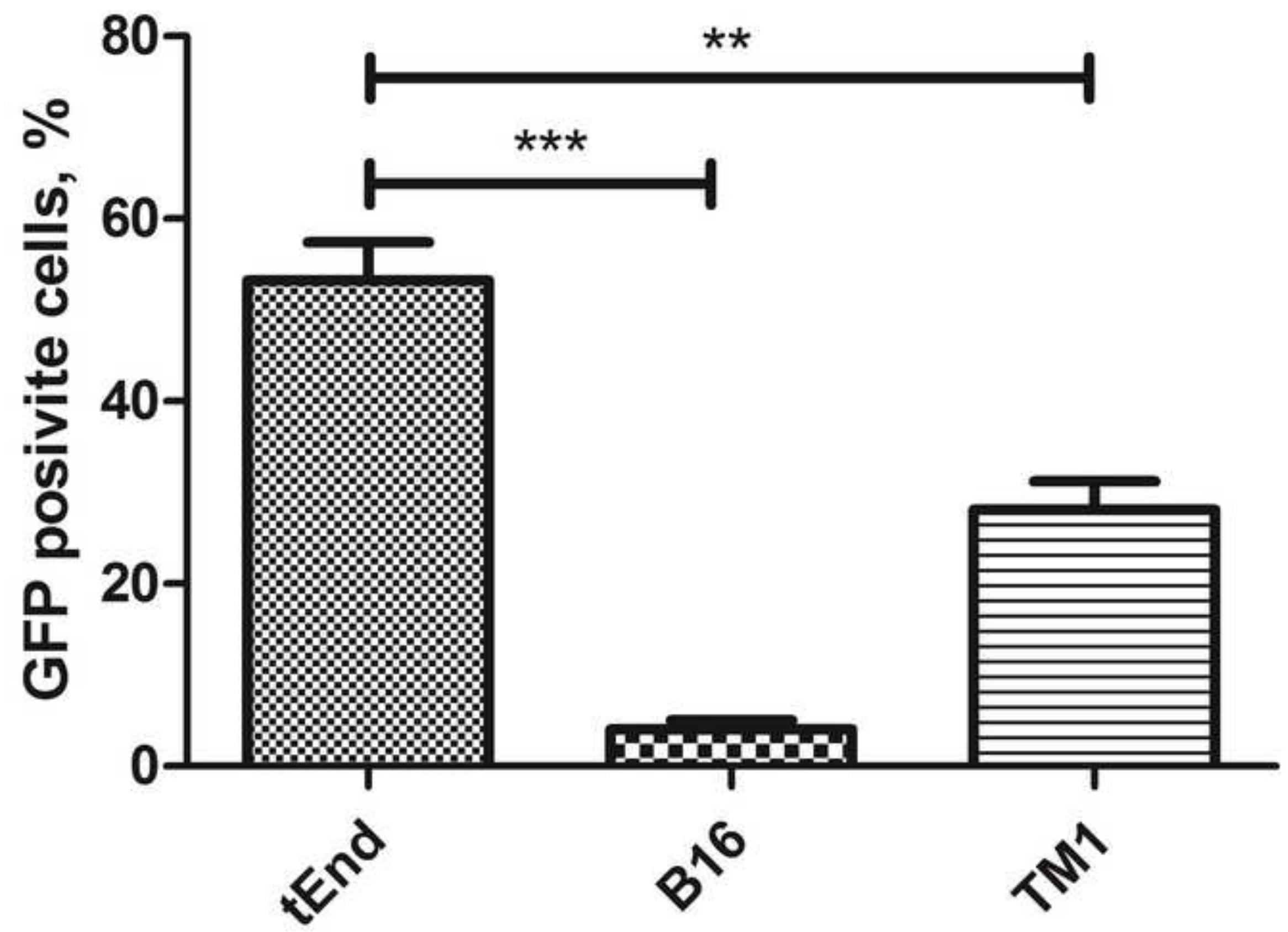


A
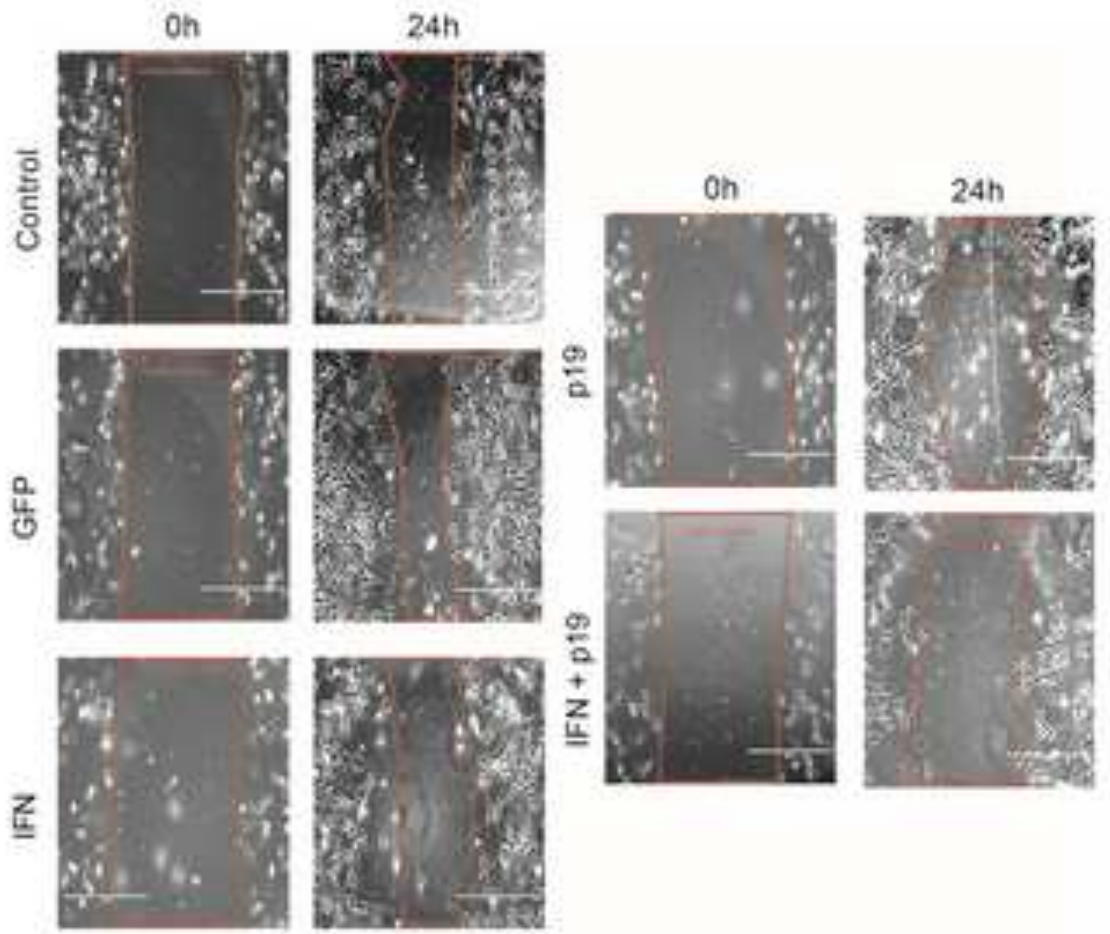

B
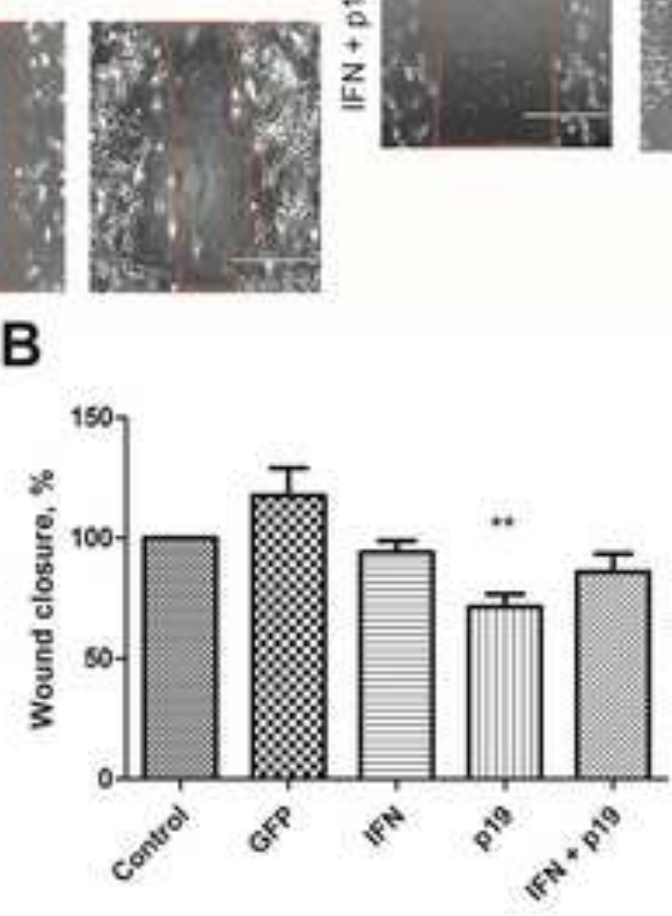

C
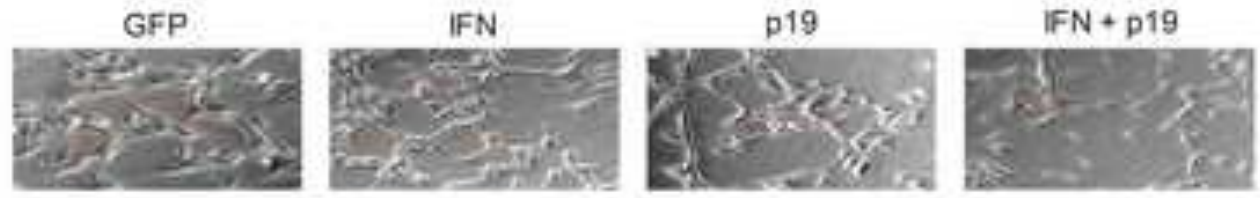

D

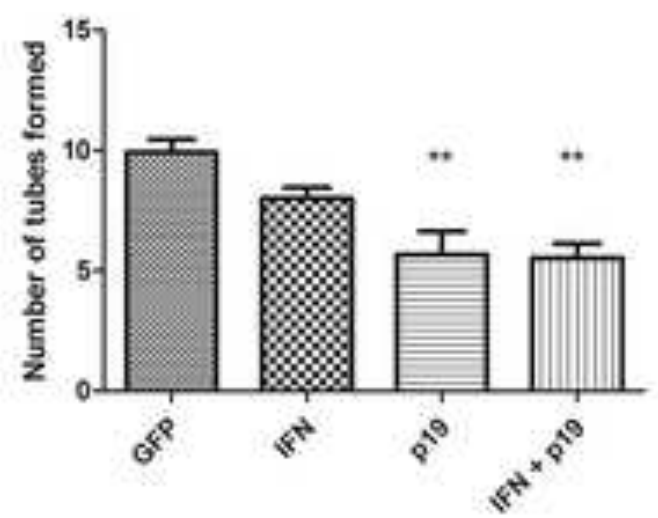


A

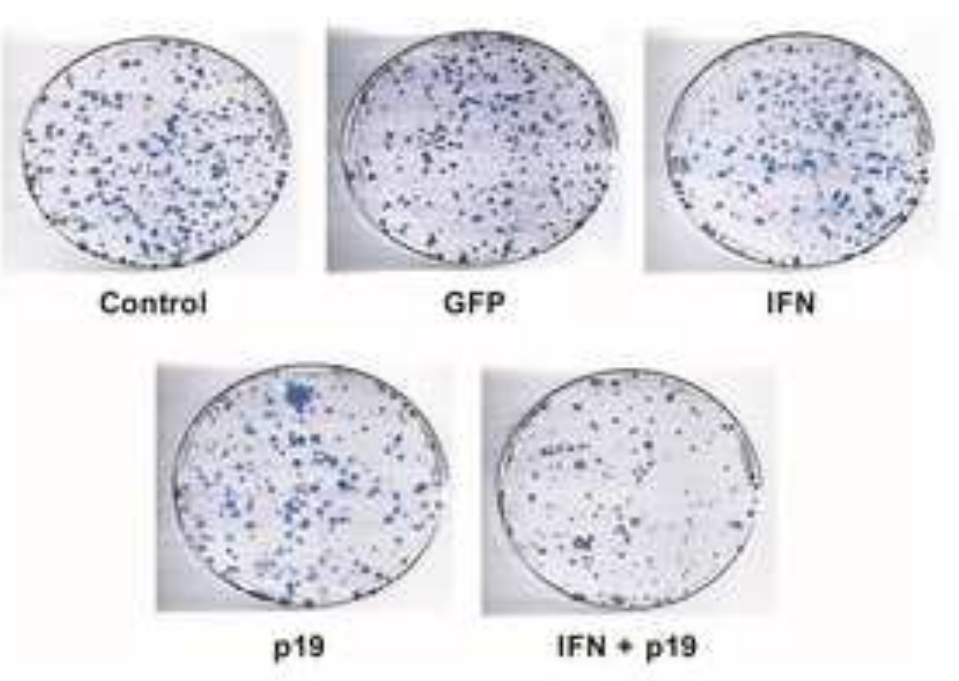

B

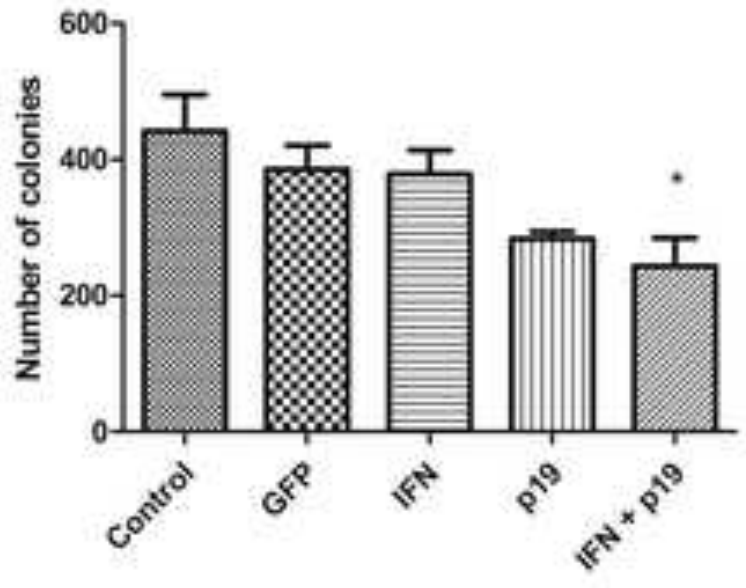

C

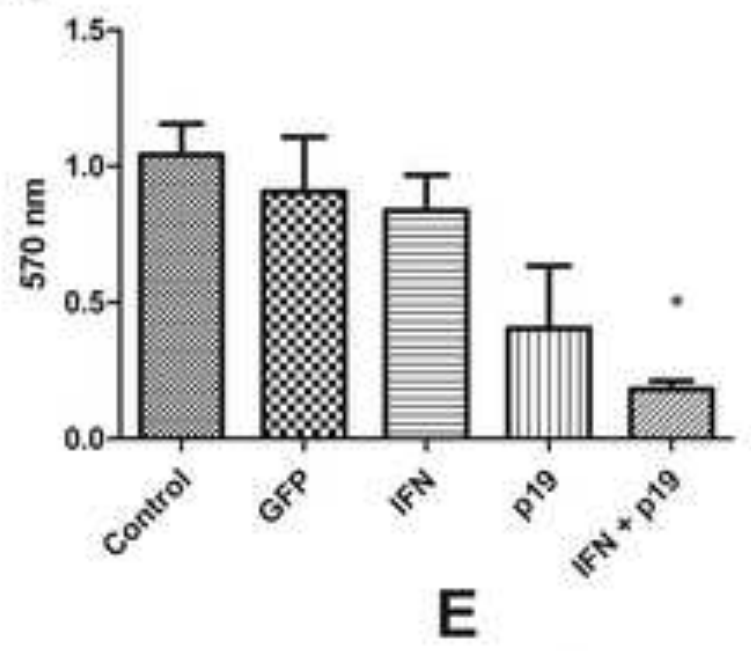

D
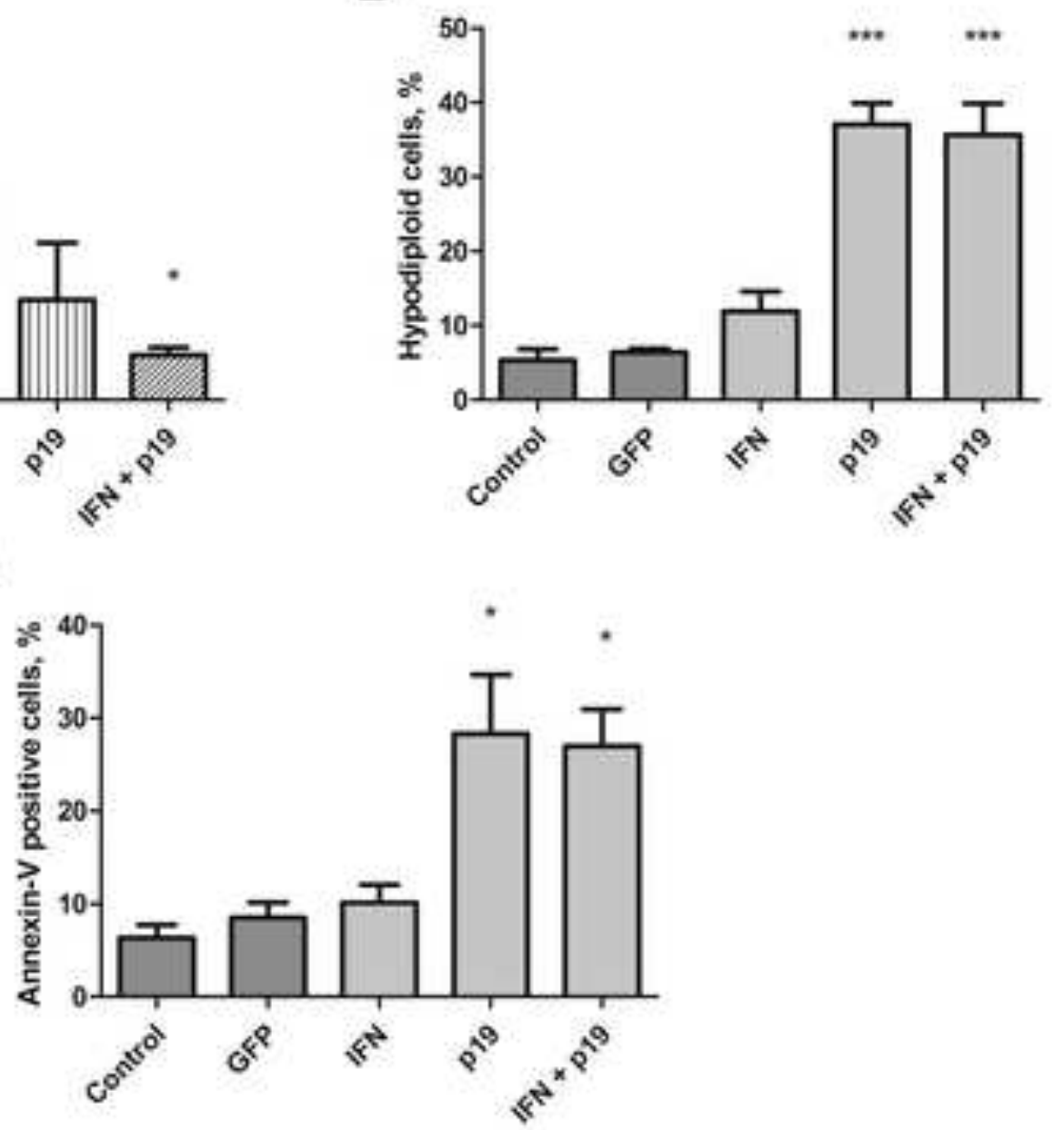

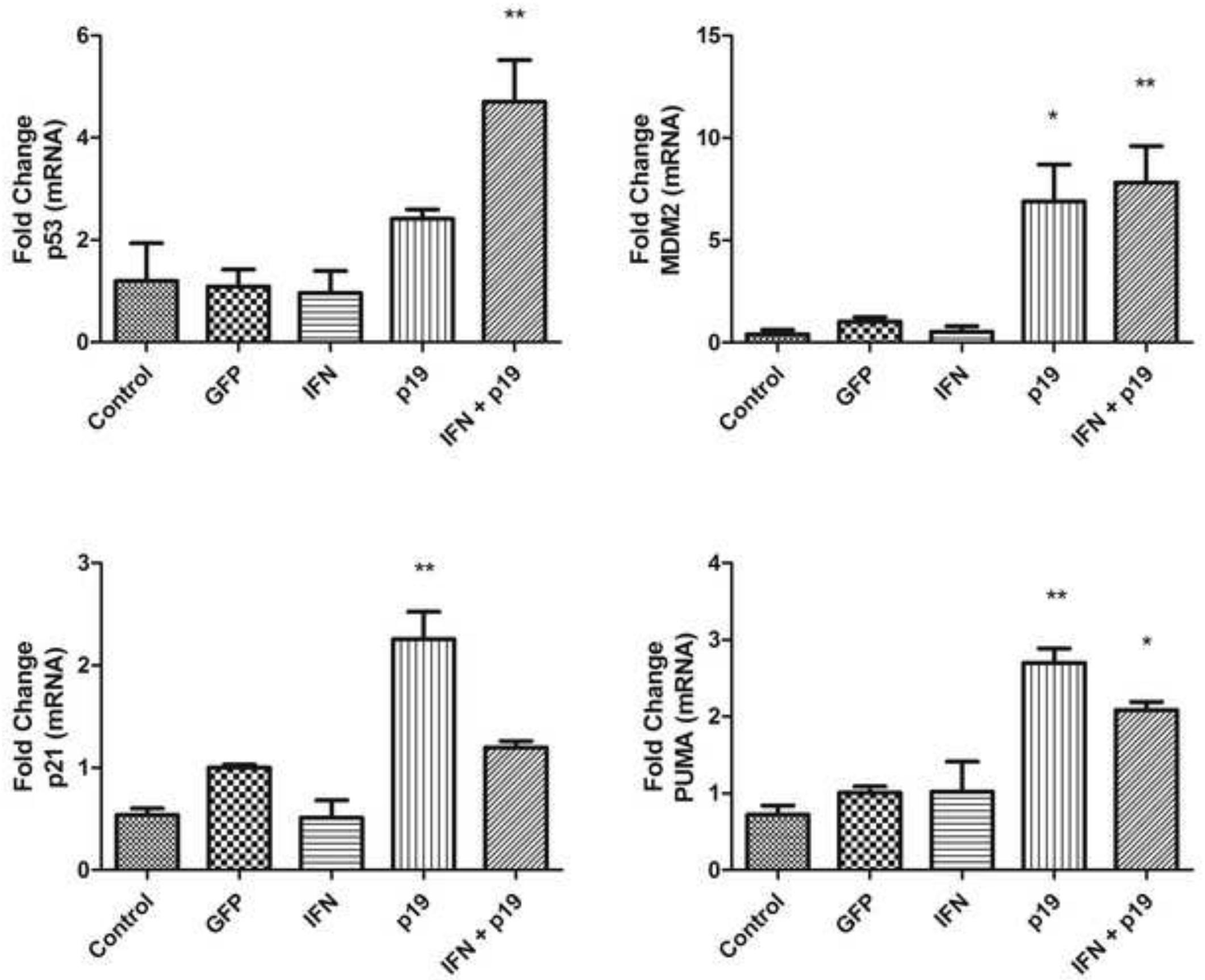
A

tEndTO / B16

$24 \mathrm{~h}$
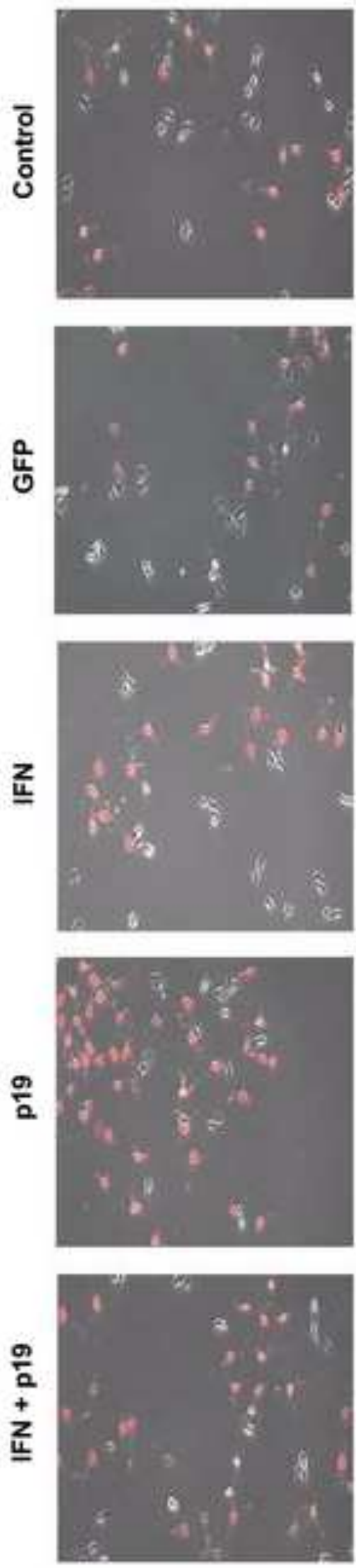

$72 \mathrm{~h}$
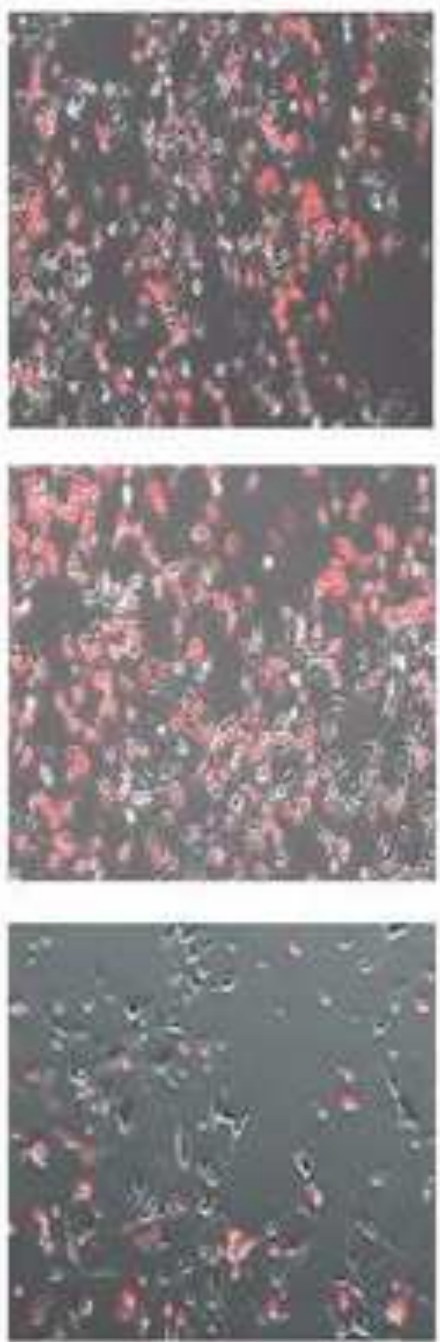

B
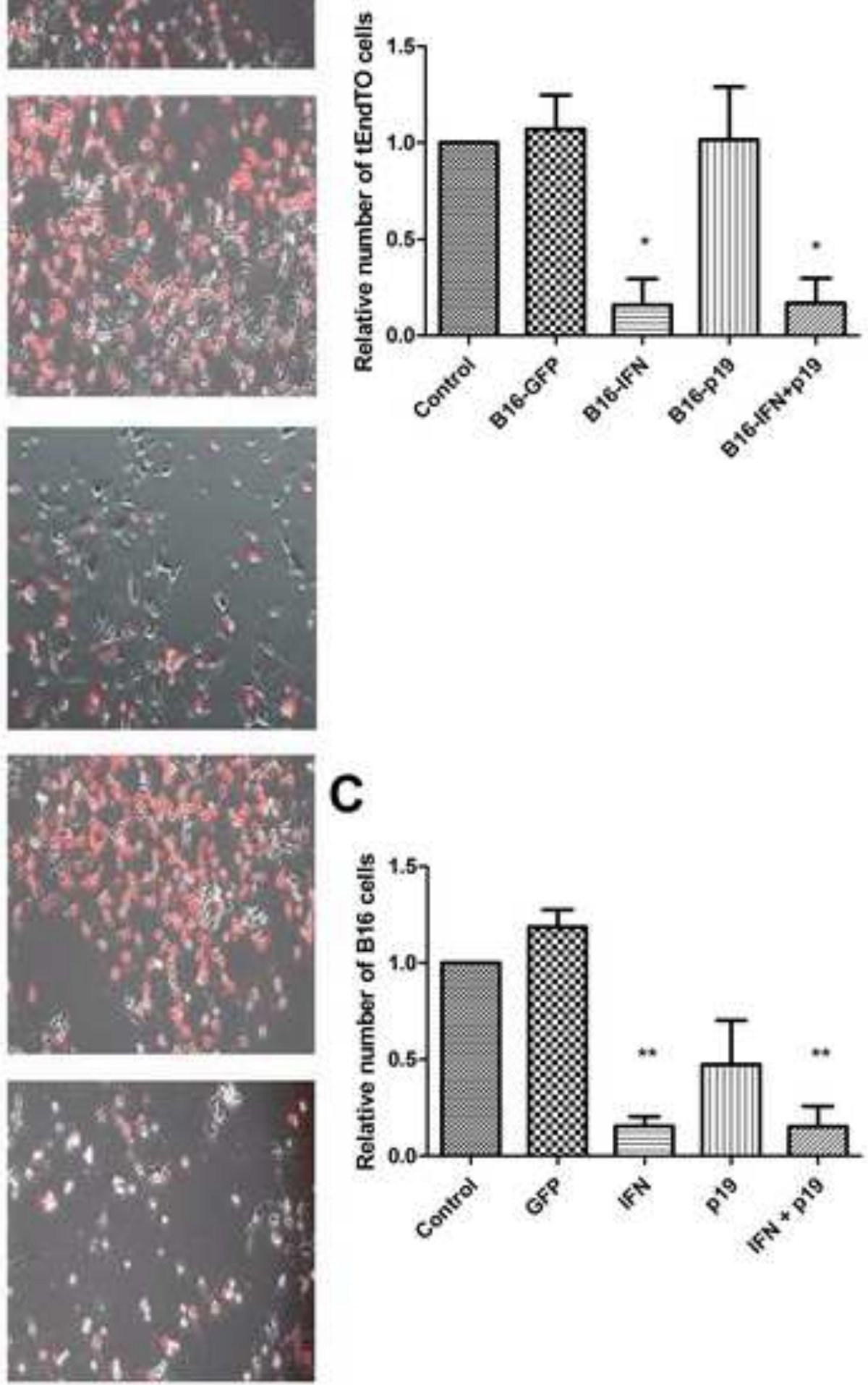

C

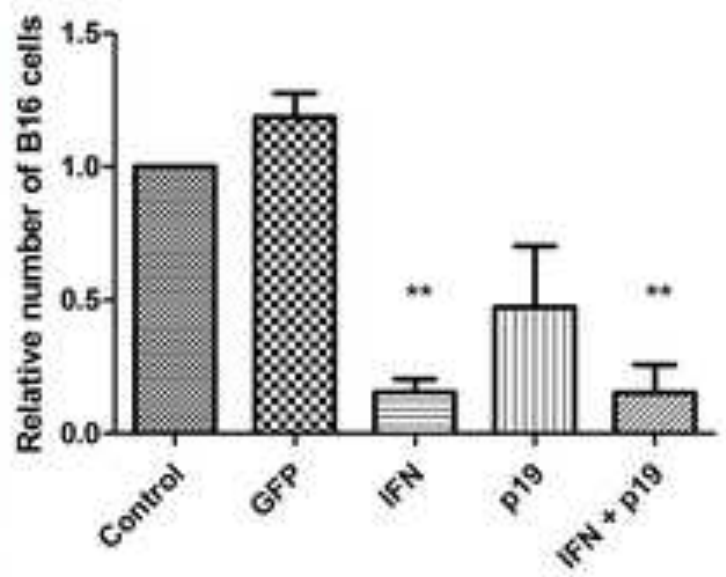


A
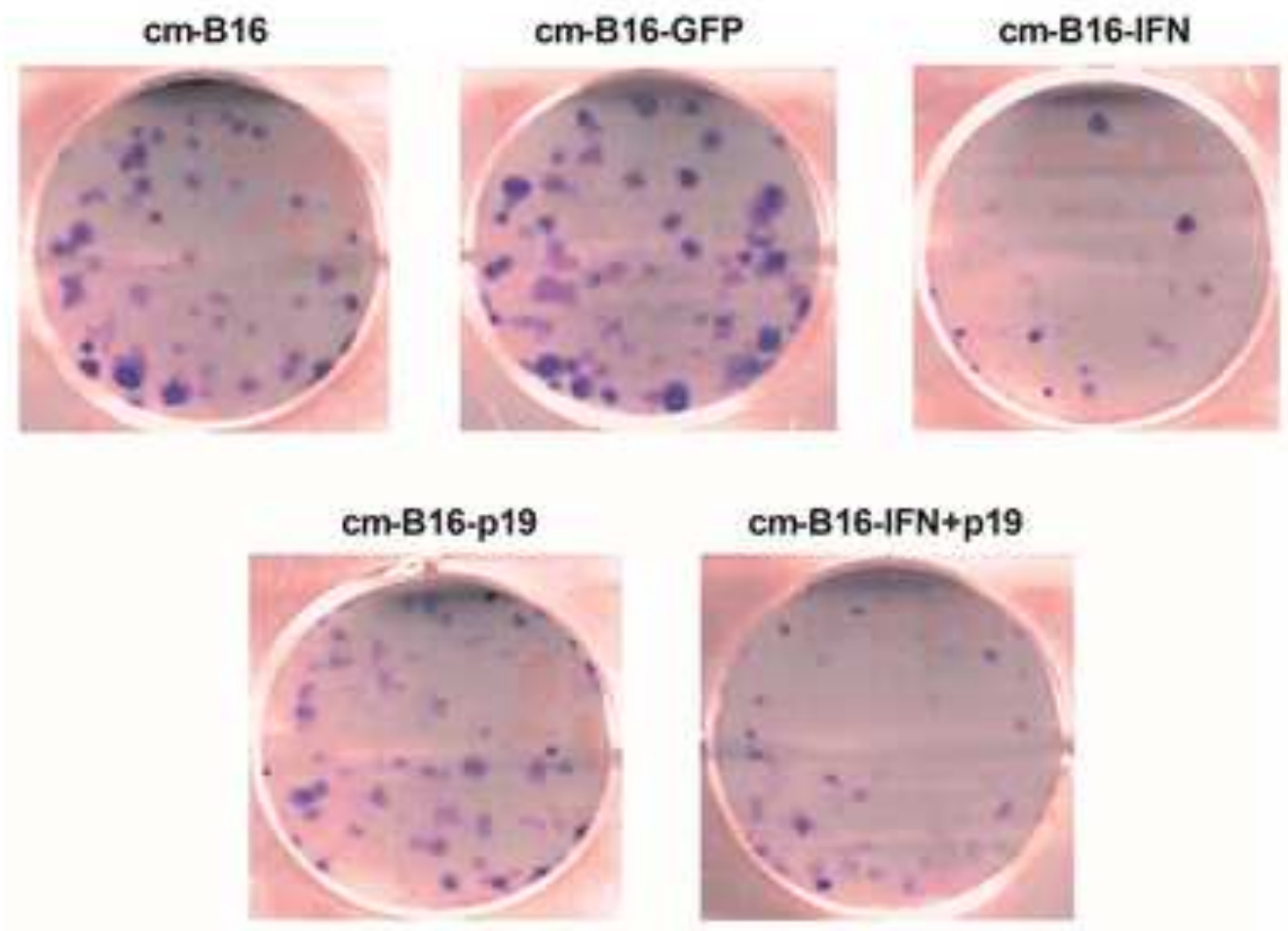

B
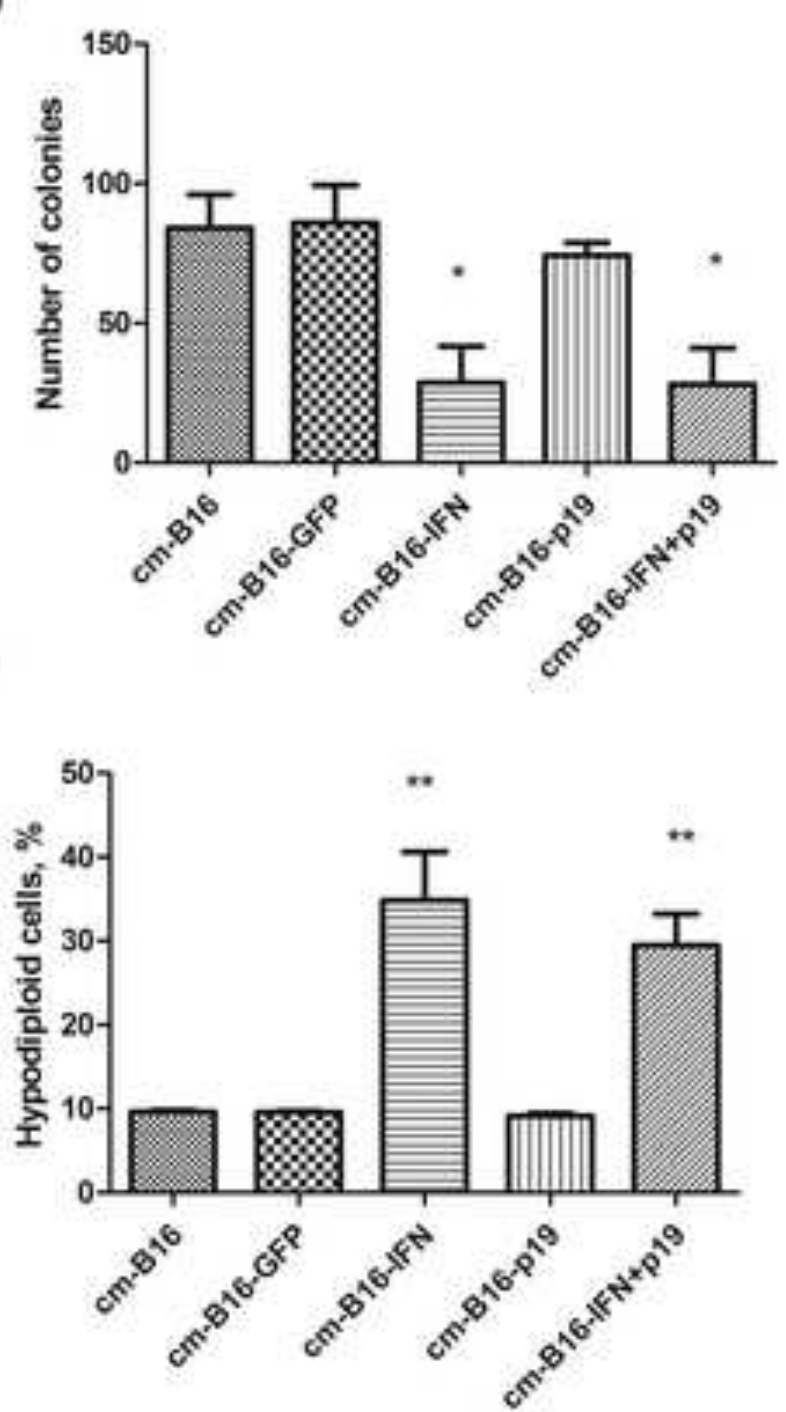

C
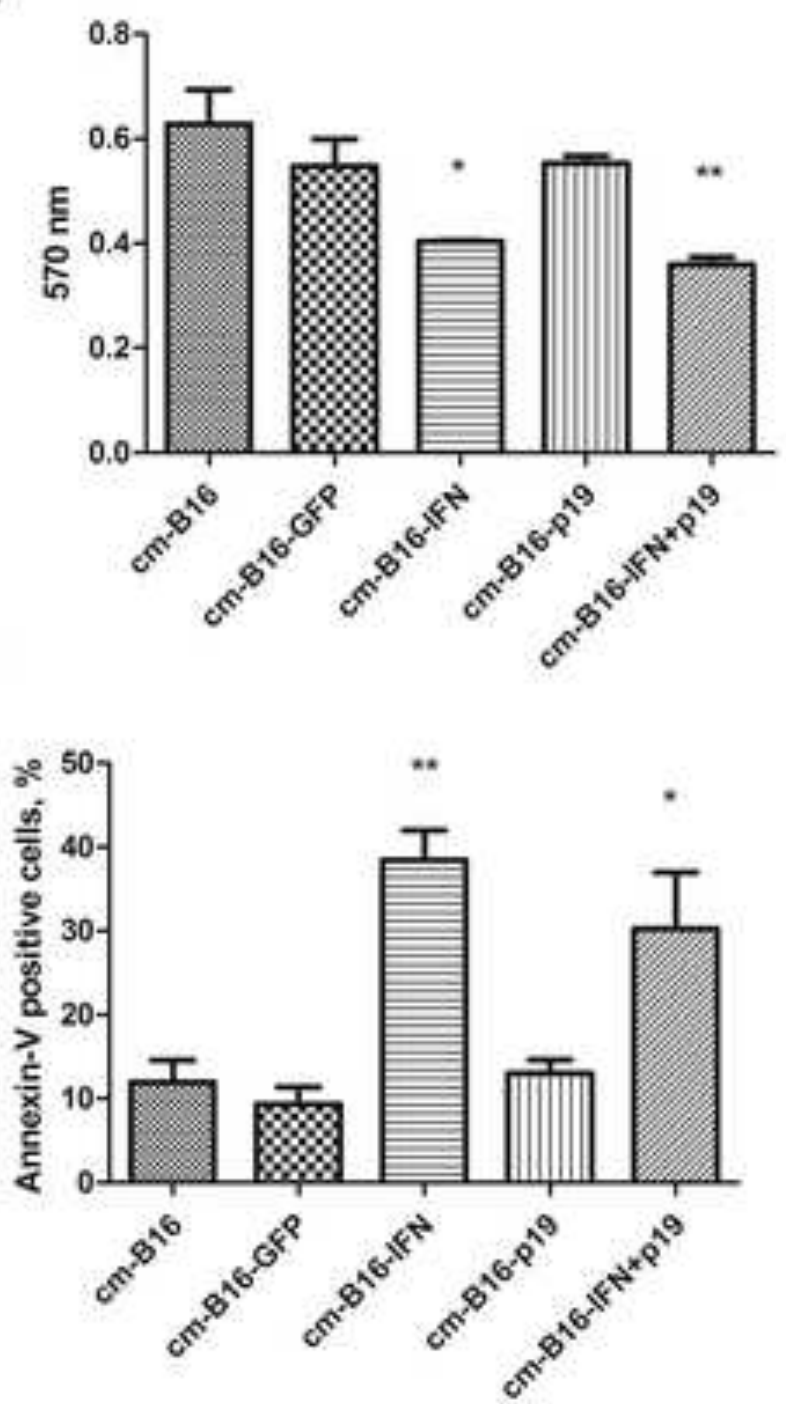
Click here to access/download Supplementary Material Additional File 1 Table S1.pdf 
Click here to access/download Supplementary Material Additional File 2 Figure S1.pdf 